Prepared in cooperation with the Pennsylvania Department of Environmental Protection and the Susquehanna River Basin Commission

\title{
Evaluation of the Streamgage Network for Estimating Streamflow Statistics at Ungaged Sites in Pennsylvania and the Susquehanna River Basin in Pennsylvania and New York
}

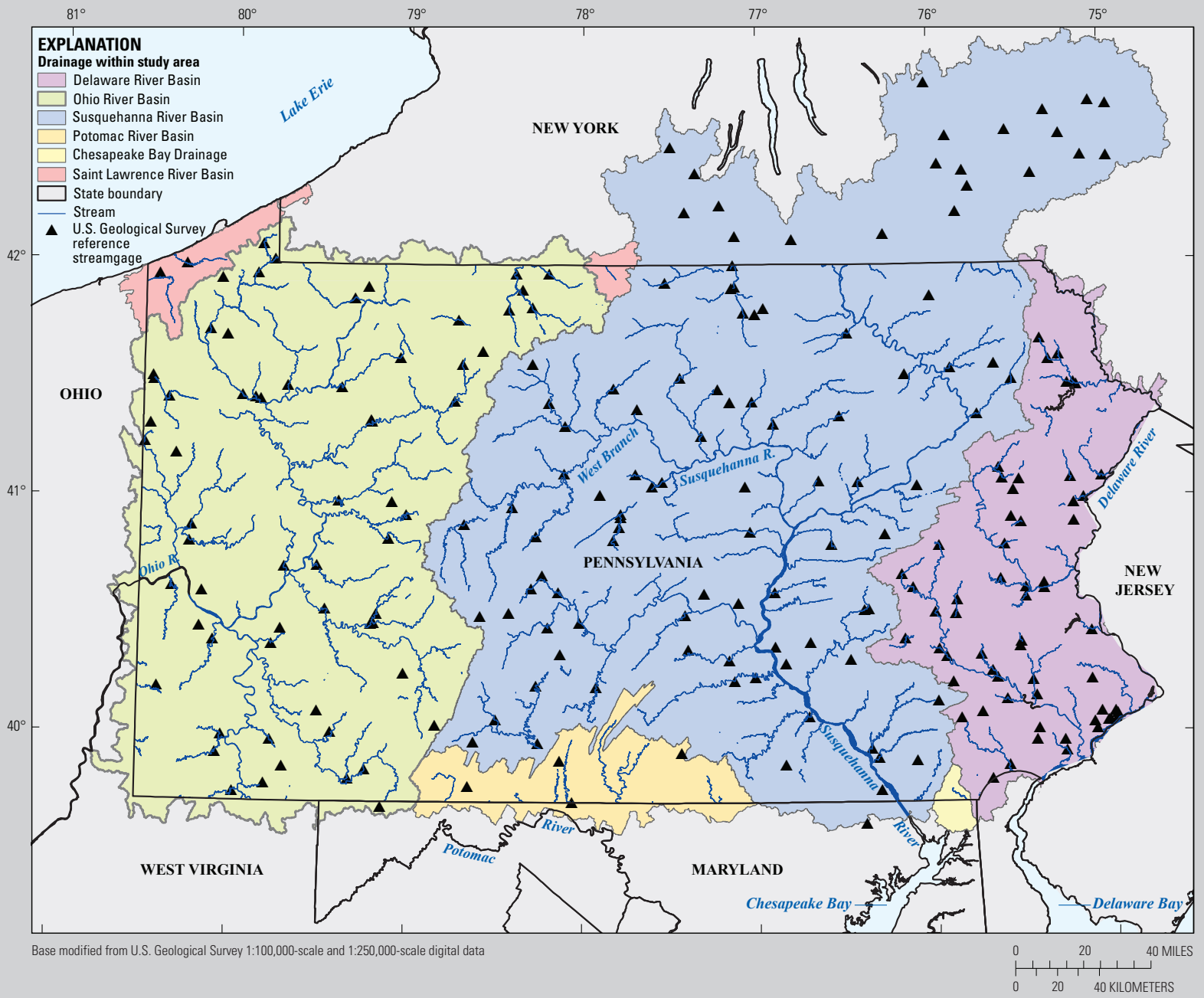

Scientific Investigations Report 2016-5149 
Cover. Map showing location of study area and U.S. Geological Survey reference streamgages in Pennsylvania and New York. Refer to figure 1. 


\section{Evaluation of the Streamgage Network for Estimating Streamflow Statistics at Ungaged Sites in Pennsylvania and the Susquehanna River Basin in Pennsylvania and New York}

By Ronald A. Sloto, Marla H. Stuckey, and Scott A. Hoffman

Prepared in cooperation with the

Pennsylvania Department of Environmental Protection

and the Susquehanna River Basin Commission

Scientific Investigations Report 2016-5149 


\title{
U.S. Department of the Interior SALLY JEWELL, Secretary
}

\section{U.S. Geological Survey Suzette M. Kimball, Director}

\author{
U.S. Geological Survey, Reston, Virginia: 2017
}

For more information on the USGS - the Federal source for science about the Earth, its natural and living resources, natural hazards, and the environment—visit https://www.usgs.gov or call 1-888-ASK-USGS

For an overview of USGS information products, including maps, imagery, and publications, visit https://store.usgs.gov

Any use of trade, product, or firm names is for descriptive purposes only and does not imply endorsement by the U.S. Government.

Although this report is in the public domain, permission must be secured from the individual copyright owners to reproduce any copyrighted materials contained within this report.

Suggested citation:

Sloto, R.A., Stuckey, M.H., and Hoffman, S.A., 2017, Evaluation of the streamgage network for estimating streamflow statistics at ungaged sites in Pennsylvania and the Susquehanna River Basin in Pennsylvania and New York:

U.S. Geological Survey Scientific Investigations Report 2016-5149, 102 p., https://doi.org/10.3133/sir20165149.

ISSN 2328-0328 (online) 


\section{Contents}

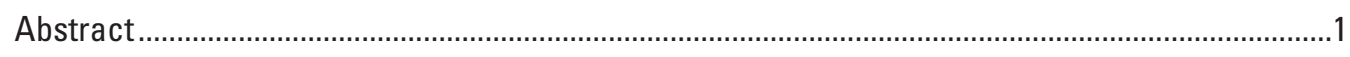

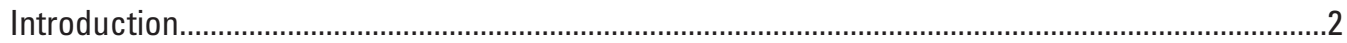

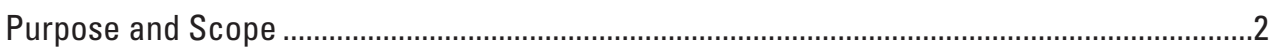

Study Area

Evaluation of Streamgage Network

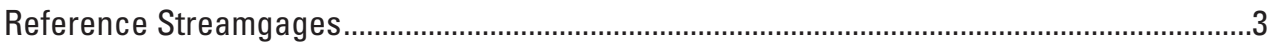

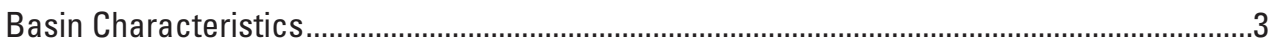

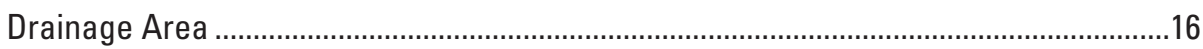

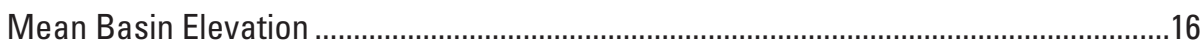

Mean Basin Slope ................................................................................................. 16

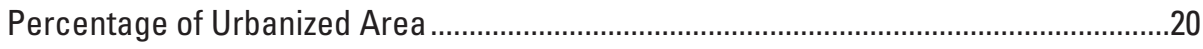

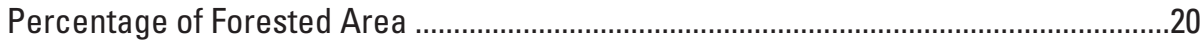

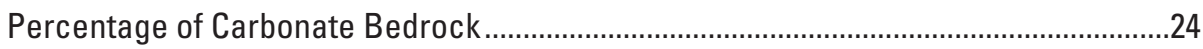

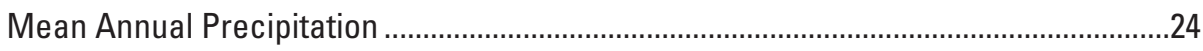

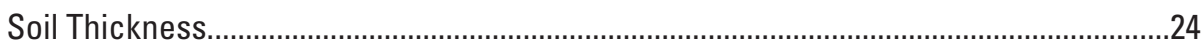

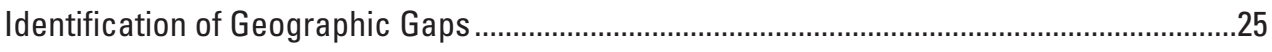

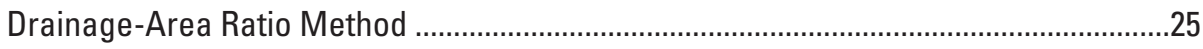

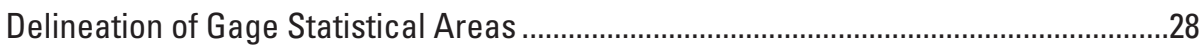

Analysis of Geographic Gaps ...............................................................................29

Estimated Streamflow Correlation of Ungaged Watersheds with Reference

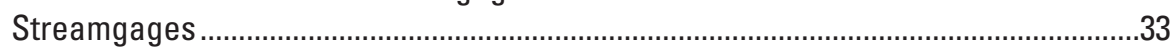

Reference Streamgage Network Gaps .................................................................................

Streamgages with High Substitution Potential in the Current Network ..........................................33

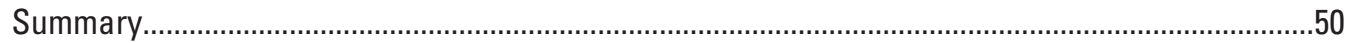

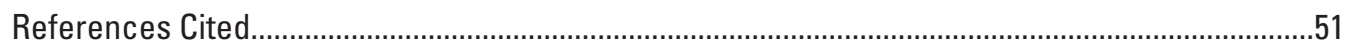

Appendix 1. Matrix of basin characteristics at U.S. Geological Survey reference streamgages in $A$, Delaware River Basin, $B$, Susquehanna and Potomac River Basins, and $C$, Ohio and Saint Lawrence River Basins in Pennsylvania and New York.

Appendix 2. Absolute percent difference between observed and transferred streamflow statistics using the drainage-area ratio method at U.S. Geological Survey streamgages in Pennsylvania and southern New York.

Appendix 3. Graphs showing absolute percent difference between observed and transferred streamflow statistics using the drainage-area ratio method at U.S. Geological Survey streamgages in Pennsylvania and southern New York.

Appendix 4. Graphs showing relation of drainage-area ratio to absolute percent difference for transferred and computed streamflow statistics for watersheds in Pennsylvania and the Susquehanna River Basin in Pennsylvania and New York.

Appendix 5. HUC12 subwatersheds in Pennsylvania and the Susquehanna River Basin in Pennsylvania and New York with basin characteristic, geographic, or streamflow correlation gaps

Appendix 6. U.S. Geological Survey streamgages in Pennsylvania with high substitution potential 


\section{Figures}

1. Map showing location of study area and U.S. Geological Survey reference streamgages in Pennsylvania and New York.

2. Graph showing comparison of basin characteristics for reference streamgages in Pennsylvania and New York...

3. Map showing basin characteristic gaps in the Delaware River Basin ...........................17

4. Map showing basin characteristic gaps in the Susquehanna River Basin.....................18

5. Map showing basin characteristic gaps in the Ohio River Basin ...................................19

6. Graph showing drainage area of reference streamgages in the Delaware

River, Susquehanna River, and Ohio River Basins. .....................................................20

7. Box plots showing the distribution of $A$, mean basin elevation, $B$, mean basin slope, $C$, percentage of urbanized area, $D$, percentage of forested area, $E$, percentage of carbonate rock, $F$, mean annual precipitation, and $G$, soil thickness for reference streamgage and 12-digit hydrologic unit code subwatersheds in Pennsylvania and New York

8. Histograms showing $A$, mean basin elevation, $B$, mean basin slope, $C$, percentage of urbanized area, $D$, percentage of forested area, $E$, percentage of carbonate rock, $F$, mean annual precipitation, and $G$, soil thickness for reference streamgage and 12-digit hydrologic unit code subwatersheds in Pennsylvania and New York.

9. Map showing gage statistical area and valid statistical reach for an example watershed.

10. Graph showing absolute percent difference between observed and transferred streamflow statistics using the drainage-area ratio method in relation to drainage-area ratio at selected U.S. Geological Survey streamgages in Pennsylvania and New York.

11. Graph showing relation between period of record and absolute percent differences for transferred streamflow statistics at selected U.S. Geological Survey streamgages in Pennsylvania and New York.

12. Graph showing example relation of drainage-area ratio to absolute percent difference for transferred streamflow statistics and streamflow statistics estimated from regression equations

13. Map showing location of 12-digit hydrologic unit code (HUC12) subwatersheds outside gage statistical areas in the Delaware River Basin

14. Map showing location of 12-digit hydrologic unit code (HUC12) subwatersheds outside gage statistical areas in the Susquehanna and Potomac River Basins

15. Map showing location of 12-digit hydrologic unit code (HUC12) subwatersheds outside gage statistical areas in the Ohio and Saint Lawrence River Basins.

16. Map showing location of a 12-digit hydrologic unit code (HUC12) subwatershed with an estimated streamflow correlation less than 0.96 in the Delaware River Basin . 
17. Map showing location of a 12-digit hydrologic unit code (HUC12) subwatershed with an estimated streamflow correlation less than 0.96

in the Susquehanna River Basin

18. Map showing location of a 12-digit hydrologic unit code (HUC12) subwatershed with an estimated streamflow correlation less than 0.96 in the Ohio River Basin

19. Map showing location of 12-digit hydrologic unit code (HUC12) subwatersheds with basin characteristic, geographic, and correlation gaps in the Delaware River Basin.

20. Map showing location of 12-digit hydrologic unit code (HUC12) subwatersheds with basin characteristic, geographic, and correlation gaps in the Susquehanna River Basin

21. Map showing location of 12-digit hydrologic unit code (HUC12) subwatersheds with basin characteristic, geographic, and correlation gaps in the Ohio River Basin

22. Map showing location of streamgages with less than 10 years of record in Pennsylvania and percent of 8-digit hydrologic unit code (HUC8) subwatersheds containing basin characteristic, geographic, and correlation gaps

\section{Tables}

1. U.S. Geological Survey reference streamgages in Pennsylvania and the Susquehanna River Basin in Pennsylvania and New York.

2. Basin characteristics used in the Pennsylvania streamgage network analysis

3. Summary statistics for basin characteristics in Pennsylvania and the Susquehanna River Basin in Pennsylvania and New York

4. Mean absolute percent difference between observed and transferred streamflow statistics using the drainage-area ratio method.

5. Summary of basin characteristic, geographic, and correlation gaps, by basin, in Pennsylvania and New York

6. 12-digit hydrologic unit code (HUC12) watersheds with basin characteristic, geographic, or correlation gaps in Pennsylvania and New York

7. Summary of watersheds exhibiting basin characteristic, geographic, and correlation gaps by 8-digit hydrologic unit code (HUC8) in Pennsylvania and New York

8. U.S. Geological Survey streamgages with high substitution potential in Pennsylvania 


\section{Conversion Factors and Datums}

\begin{tabular}{|c|c|c|}
\hline Multiply & By & To obtain \\
\hline \multicolumn{3}{|c|}{ Length } \\
\hline inch (in.) & 2.54 & centimeter $(\mathrm{cm})$ \\
\hline foot $(\mathrm{ft})$ & 0.3048 & meter $(\mathrm{m})$ \\
\hline mile (mi) & 1.609 & kilometer (km) \\
\hline \multicolumn{3}{|c|}{ Area } \\
\hline square mile $\left(\mathrm{mi}^{2}\right)$ & 2.590 & square kilometer $\left(\mathrm{km}^{2}\right)$ \\
\hline \multicolumn{3}{|c|}{ Volume } \\
\hline cubic foot $\left(\mathrm{ft}^{3}\right)$ & 0.02832 & cubic meter $\left(\mathrm{m}^{3}\right)$ \\
\hline
\end{tabular}

Vertical coordinate information is referenced to the North American Vertical Datum of 1988 (NAVD 88).

Horizontal coordinate information is referenced to the North American Datum of 1983 (NAD 83).

Elevation, as used in this report, refers to distance above the vertical datum.

\section{Abbreviations}

GSA

PaDEP

SRBC

USGS

VSR
Gage statistical area

Pennsylvania Department of Environmental Protection

Susquehanna River Basin Commission

U.S. Geological Survey

Valid statistical reach 


\title{
Evaluation of the Streamgage Network for Estimating Streamflow Statistics at Ungaged Sites in Pennsylvania and the Susquehanna River Basin in Pennsylvania and New York
}

\author{
By Ronald A. Sloto, Marla H. Stuckey, and Scott A. Hoffman
}

\begin{abstract}
The current (2015) streamgage network in Pennsylvania and the Susquehanna River Basin in Pennsylvania and New York was evaluated in order to design a network that would meet the hydrologic needs of many partners and serve a variety of purposes and interests, including estimation of streamflow statistics at ungaged sites. This study was done by the U.S. Geological Survey, in cooperation with the Pennsylvania Department of Environmental Protection and the Susquehanna River Basin Commission. The study area includes the Commonwealth of Pennsylvania and the Susquehanna River Basin in Pennsylvania and New York. For this study, 229 streamgages were identified as reference streamgages that could be used to represent ungaged watersheds. Criteria for a reference streamgage are a minimum of 10 years of continuous record, minimally altered streamflow, and a drainage area less than 1,500 square miles. Some of the reference streamgages have been discontinued but provide historical hydrologic information valuable in the determination of streamflow characteristics of ungaged watersheds. Watersheds in the study area not adequately represented by a reference streamgage were identified by examining a range of basin characteristics, the extent of geographic coverage, and the strength of estimated streamflow correlations between gaged and ungaged sites.

Basin characteristics were determined for the reference streamgage watersheds and the 1,662 12-digit hydrologic unit code (HUC12) subwatersheds in Pennsylvania and the Susquehanna River Basin using a geographic information system (GIS) spatial analysis and nationally available GIS datasets. Basin characteristics selected for this study include drainage area, mean basin elevation, mean basin slope, percentage of urbanized area, percentage of forested area, percentage of carbonate bedrock, mean annual precipitation, and soil thickness. A GIS spatial analysis was used to identify
\end{abstract}

HUC12 subwatersheds outside the range of basin characteristics of the reference streamgages. There were $320 \mathrm{HUC12}$ subwatersheds, or 19 percent of the study area, with basin characteristics outside the range represented by the reference streamgage watersheds.

A GIS spatial analysis was used to identify geographic gaps in the streamgage network. For each streamgage, a watershed area, called the gage statistical area (GSA), was delineated. The GSA shows the drainage area within a specific drainage-area ratio of the streamgage for transfer of streamflow statistics from that streamgage to ungaged sites on the valid statistical reach of the GSA for a streamgage. In Pennsylvania, a drainage-area ratio of 0.33-3 times the drainage area of the ungaged site was found to perform as well as, if not better than, more traditional ratios such as $0.5-1.5$ (or 2) for transfer of selected streamflow statistics. A total of 1,102 HUC12 subwatersheds, or 66 percent of the study area, are outside the GSA for a reference streamgage.

The USGS Baseline Streamflow Estimator (BaSE) program was used to determine how well HUC12 subwatersheds outside the streamgage GSAs are represented by the reference streamgage network in Pennsylvania, based on estimated streamflow correlation. The centroid of each HUC12 subwatershed was run through the BaSE program to determine the reference streamgage with the highest estimated streamflow correlation. There were 929 HUC12 subwatersheds in Pennsylvania, or 56 percent of the State, with an estimated correlation coefficient less than 0.96 .

The results from the basin characteristic, geographic, and streamflow correlation analyses were combined to identify 1,405 HUC12 subwatersheds in Pennsylvania and the Susquehanna River Basin in Pennsylvania and New York that lack a representative reference, based on at least one identified gap. Of the 1,405 HUC12 subwatersheds, 139 exhibited all three gaps, indicating a 8-percent gap in the reference streamgage network. 
Streamgages in areas with similar hydrologic characteristics and in close proximity to one another can potentially provide similar information (termed streamgages with high substitution potential). Streamgages were considered to have a high substitution potential with a nearby streamgage(s) if (1) the streamflow correlation coefficient was equal to or greater than $0.96,(2)$ the streamgages had 10 years of concurrent record, and (3) the streamgages are in the same watershed within the GSA of the streamgage. Seventy-four current (2015) streamgages with high substitution potential with at least one other streamgage were identified in the study area. Although these identified streamgages have a high substitution potential, they provide valuable streamflow information to a stakeholder. Selected primary uses of these streamgages were identified to determine the overall need for an individual streamgage.

\section{Introduction}

The first state-wide systematic measurement of streamflow in Pennsylvania began in the late 1800s. The establishment of a streamgage network began in the early 1930s when the Pennsylvania Department of Forest and Waters entered into a cooperative agreement with the U.S. Geological Survey (USGS) to provide for the collection and reporting of streamflow data (Durlin, 2009). The streamgages in this network were geographically located, and the primary objective was to document hydrologic resources and to forecast floods in Pennsylvania.

As needs changed for streamflow data over the years, streamgages were discontinued, new streamgages were established, and discontinued streamgages were reactivated. In addition to the scientific and engineering needs for streamgaging, regulatory and socio-economic factors have influenced the growth and decline of the USGS streamgage network in Pennsylvania. The current (2015) streamgage network is, in part, the result of requests of cooperating partners who require hydrologic data, possibly at specific locations. The resulting streamgage network may meet the needs of USGS cooperative partners but may not be ideal for establishing a reference streamgage network.

In a reference streamgage network, gaged watersheds represent composites of the upstream land cover, basin features, and hydrologic characteristics. Streamflow statistics from reference streamgages can be transferred to ungaged watersheds with similar land cover and basin features to estimate streamflow statistics. Although many of the current streamgages can be used as reference streamgages, an analysis was needed in order to design a network that would meet the hydrologic needs of many partners and serve many purposes and interests.

In 2015, the USGS operated and maintained approximately 300 real-time, continuous-record discharge streamgages across Pennsylvania that provided valuable hydrologic data for many Federal, State, and local waterresource agencies, and private industries for a variety of purposes, including regulatory, drought and flood forecasting, and long-term baseline data collection. In addition to the approximately 300 continuous-record discharge streamgages, the USGS has operated many continuous-record discharge streamgages in the past that have been discontinued because of lack of funding or changing priorities on the part of the funding cooperator. These streamgages, past and present, have drainage areas ranging in size from less than 5 square miles $\left(\mathrm{mi}^{2}\right)$ to $26,000 \mathrm{mi}^{2}$. Of all the streamgages, those on waterways that are minimally affected by regulation, diversion, or mining and have at least 10 years of continuous record are referred to as "reference streamgages." Although some of the reference streamgages are not currently operating, they still provide historical hydrologic information valuable in the determination of streamflow characteristics of ungaged watersheds.

The Pennsylvania Department of Environmental Protection (PaDEP), along with the Susquehanna River Basin Commission (SRBC), oversees the review and approval of many water-resource projects, including permit applications related to public water supplies and commercial and industrial activities, such as the unconventional development of shale gas. Streamgages monitoring continuous streamflow are used by the PaDEP and SRBC to evaluate water-withdrawal permits and to ensure that instream flow protection requirements are being met. The PaDEP and SRBC use reference streamgages to assist in the review of permit applications for water withdrawals in ungaged areas of the State by estimating streamflow statistics for the ungaged watershed. With the unconventional development of shale gas, there has been an increase in water-withdrawal permit applications, making the need for reliable streamflow data ever more critical. The USGS, in cooperation with the PaDEP and the SRBC, evaluated the streamgaging network for purposes of estimating streamflow statistics at ungaged sites in Pennsylvania and the Susquehanna River Basin in Pennsylvania and New York.

\section{Purpose and Scope}

This report presents an evaluation of the reference streamgage network in Pennsylvania and the Susquehanna River Basin to determine whether it provides representative hydrologic information for all ungaged basins in Pennsylvania and the Susquehanna River Basin in New York and Pennsylvania for the purpose of estimating streamflow statistics. Ungaged 12-digit hydrologic unit code (HUC12) subwatersheds that are not adequately represented by a reference streamgage are identified. In addition, streamgages in the current (2015) streamgaging network with similar hydrologic characteristics and in close proximity to one another that could potentially provide similar information are also identified. 


\section{Study Area}

The study area includes the Commonwealth of Pennsylvania and the part of the Susquehanna River Basin in New York (fig.1). A small part of the Susquehanna River Basin extends into Maryland but was not included in this analysis. The analysis includes HUC12 subwatersheds that straddle the Pennsylvania border, including small areas in Delaware, Maryland, New Jersey, New York, Ohio, and West Virginia, in addition to the HUC12 subwatersheds in the part of the Susquehanna River Basin in New York. Pennsylvania has three major river basins and three smaller river basins. The watersheds contain more than 98,100 linear miles of streams in the State. The Delaware River forms the boundary between Pennsylvania and New Jersey on the east, and the river flows south into the Delaware Bay. The Susquehanna River Basin is in the central part of the State, and the river flows south from New York into the Chesapeake Bay in Maryland. The Ohio River Basin drains the western part of the State, including the Allegheny and Monongahela Rivers, and the river flows into the Mississippi River and ultimately the Gulf of Mexico (not shown). The three river basins with small areas in Pennsylvania include the Potomac River Basin in the southcentral part of the State; the Saint Lawrence River Basin in the northwestern part of the State, and the Chesapeake Bay Drainage in the southeastern part of the State that drains directly into the Chesapeake Bay.

\section{Evaluation of Streamgage Network}

Reference streamgages represent ungaged watersheds and can be used to estimate streamflow statistics and other hydrologic information for an ungaged watershed. Not all watersheds may be adequately represented by a reference streamgage. Watersheds that may not be adequately represented by a reference streamgage were identified by examining the range of basin characteristics, the extent of geographic coverage, and the strength of estimated streamflow correlations between gaged and ungaged sites.

The HUC12 subwatersheds represent the smallest watershed division in the hydrologic unit accounting system. A cataloging unit is defined as a geographic area representing part or all of a surface-water drainage basin, a combination of drainage basins, or a distinct hydrologic feature (Seaber and others, 1987). HUC12 subwatersheds subdivide the regions and accounting units into smaller areas. HUC12 boundaries are defined by hydrographic and topographic criteria that delineate an area upstream from a specific point on a stream. It is important to note that hydrologic units are synonymous with traditional watersheds only when all the upstream source area contributing to surface water is included (U.S. Geological Survey and U.S. Department of Agriculture, Natural Resources Conservation Service, 2013).

\section{Reference Streamgages}

For this study, 229 streamgages were identified in (or near) Pennsylvania and the Susquehanna River Basin for use as reference streamgages (table 1; fig. 1). Of those streamgages, 208 are in (or near) Pennsylvania, and 21 are in the Susquehanna River Basin outside of Pennsylvania. The criterion for a streamgage to be considered a reference streamgage is a minimum of 10 years of continuous record with minimally altered streamflow without significant alteration from flood-control reservoirs, mining, or other anthropogenic activities. Streamgages with current regulation were considered to be a reference streamgage if there was at least 10 years of minimally altered streamflow record prior to the start of regulation. Drainage basin size for a reference streamgage was limited to a maximum of $1,500 \mathrm{mi}^{2}$. Basins larger than 1,500 $\mathrm{mi}^{2}$ typically contain extensive regulation, diversion, and other anthropogenic influences and are not suitable for transference of streamflow statistics to other unregulated streams.

\section{Basin Characteristics}

Basin characteristics represent the physical, ecological, and climatological aspects of watersheds and are used to assess how well a reference streamgage may represent an ungaged watershed. Basin characteristics selected for this analysis are drainage area, mean basin elevation, mean basin slope, percentage of urbanized area, percentage of forested area, percentage of carbonate bedrock, mean annual precipitation, and soil thickness (table 2). The selected basin characteristics are widely used in hydrologic and ecological studies and have been found to be important for evaluating streamflow in Pennsylvania and New York (Stuckey, 2006; Stuckey and Reed, 2000; Roland and Stuckey, 2008; Stuckey and others, 2012; Risser and others, 2008; Barnes, 1986; Randall, 2010; Lumia and others, 2006; Stedfast, 1986). Drainage area was a significant predictor variable for all recent regression studies in New York and Pennsylvania. Mean annual precipitation was significant for most of the studies. Percentage of carbonate bedrock was significant for all recent regression studies in Pennsylvania. All of the selected basin characteristics were significant in at least one of the recent regression analyses and are listed in table 2. Only basin characteristics that could easily be determined from nationally available geographic information system (GIS) datasets were considered. Land use changes over time were not considered as part of this project.

Basin characteristics were determined for the 229 USGS reference streamgages using GIS spatial analysis. Basin characteristics also were determined for 1,662 HUC12 subwatersheds in Pennsylvania and the upper Susquehanna River Basin in New York. The basin characteristics were determined for each HUC12 subwatershed, regardless of any upstream 


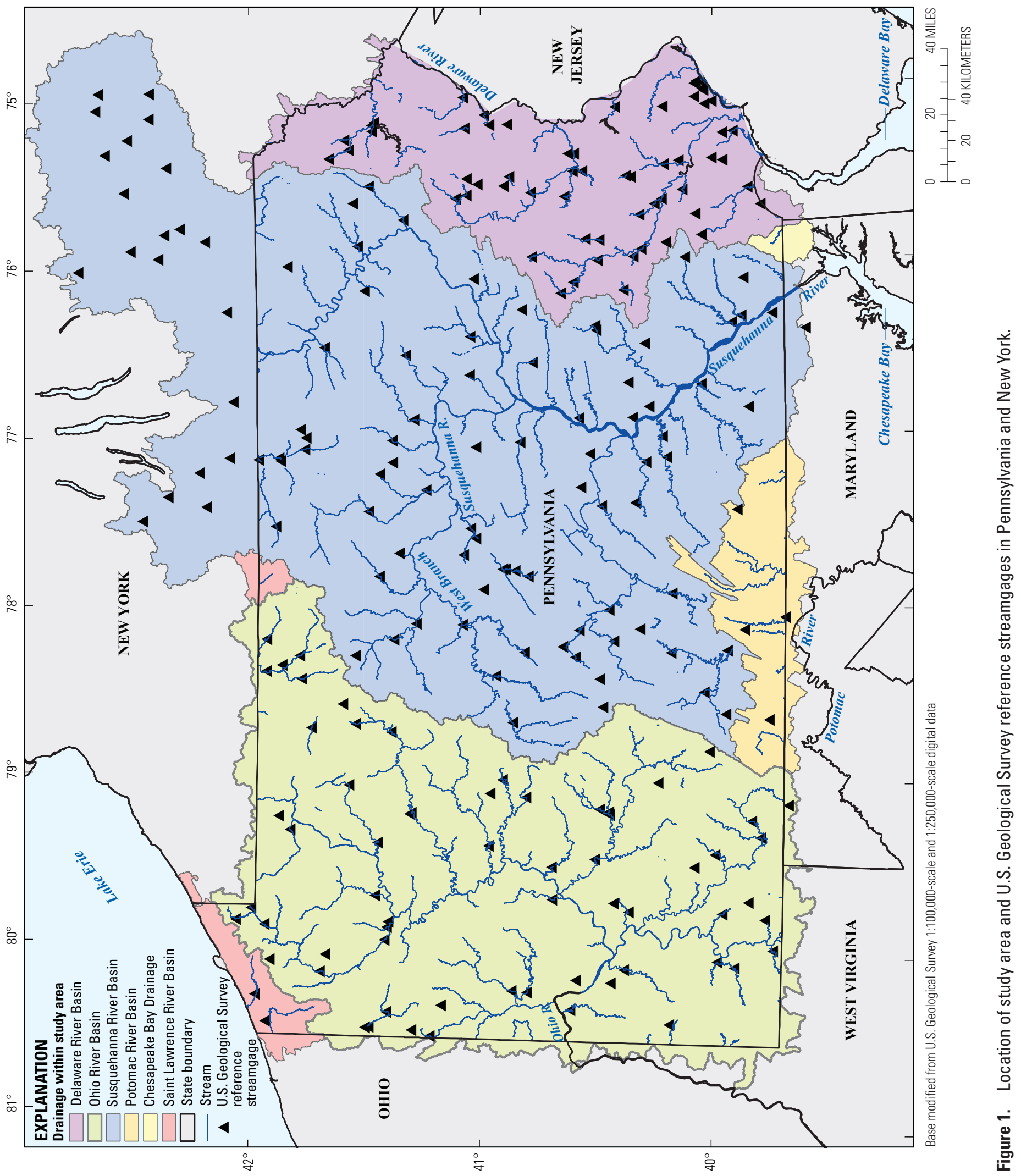




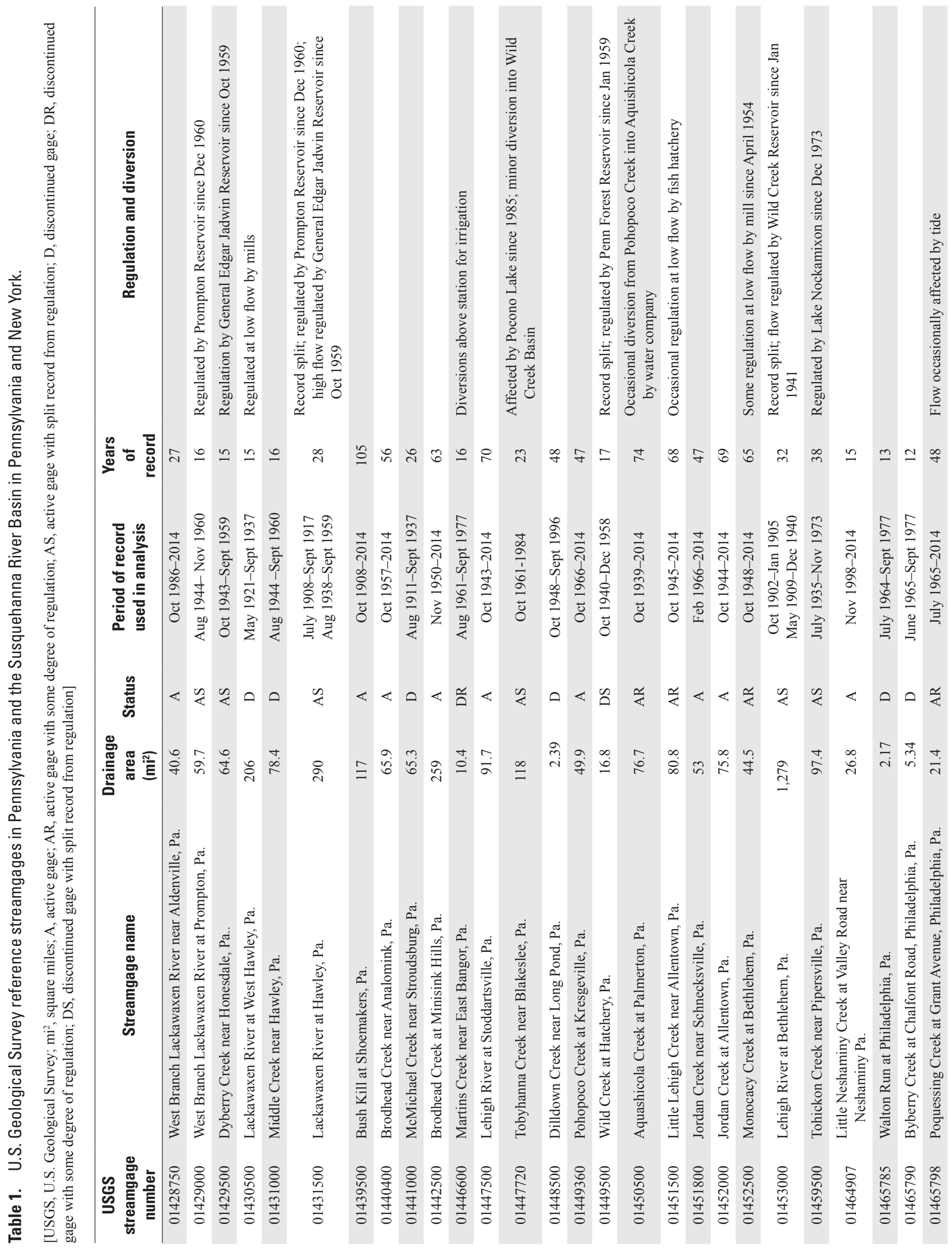




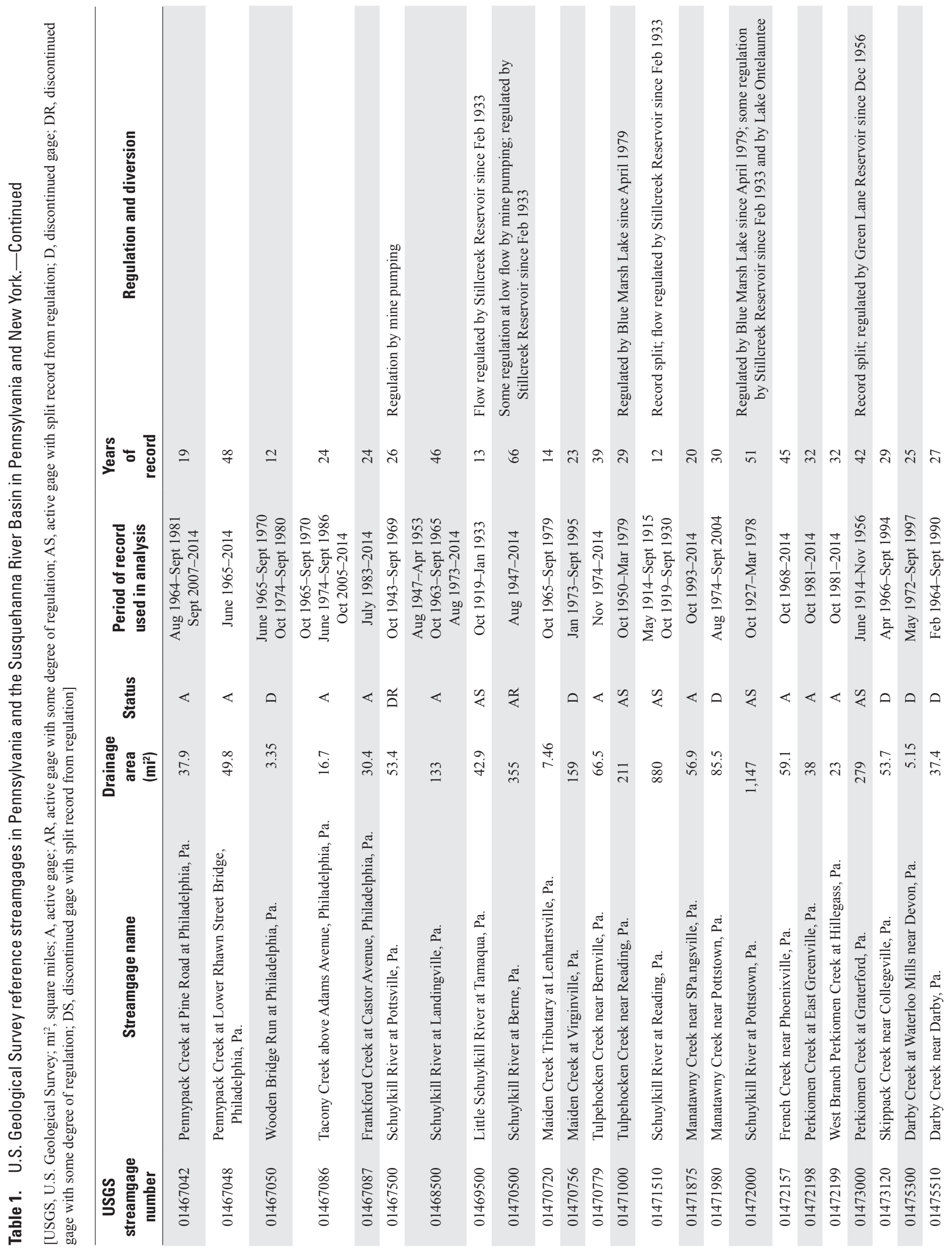




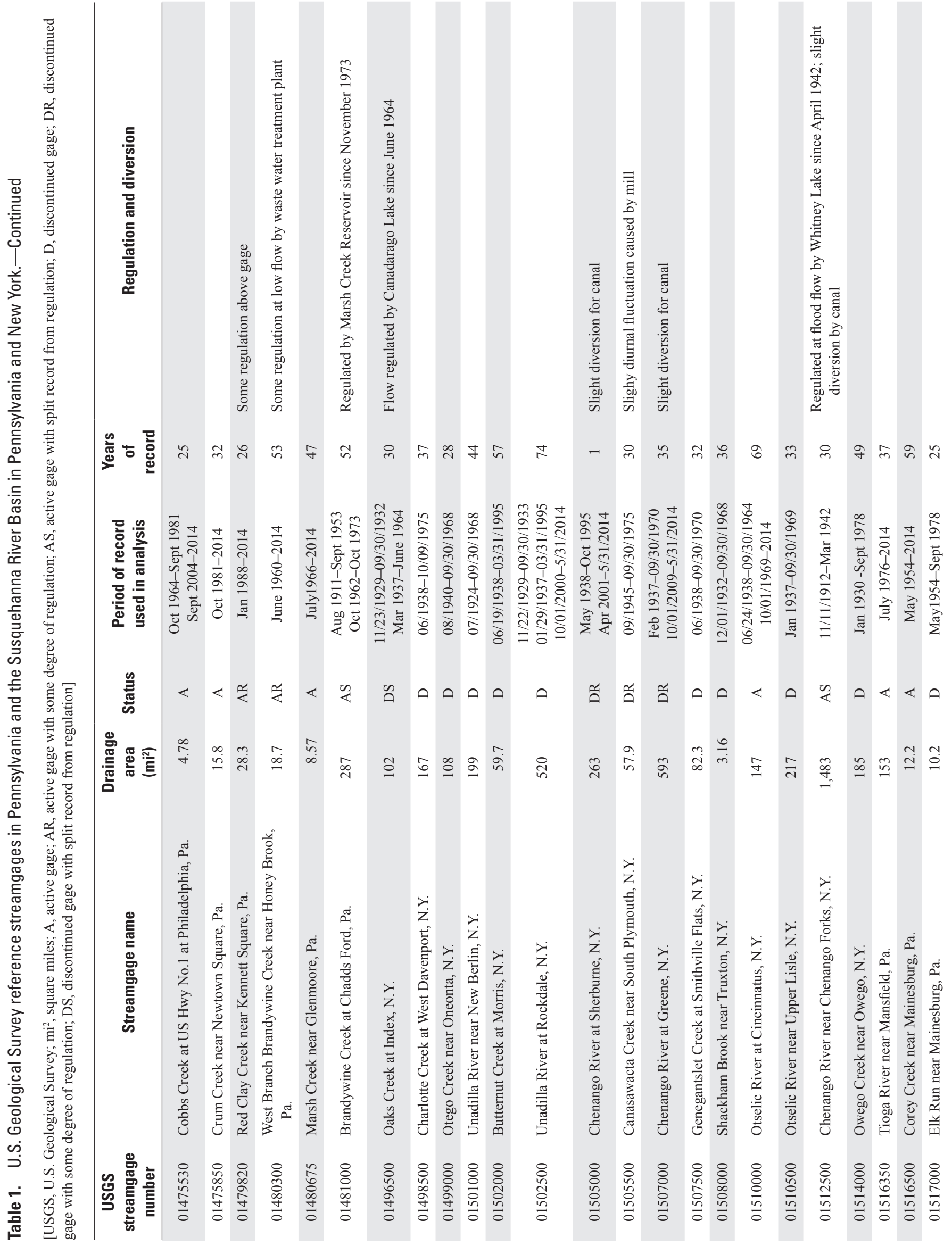




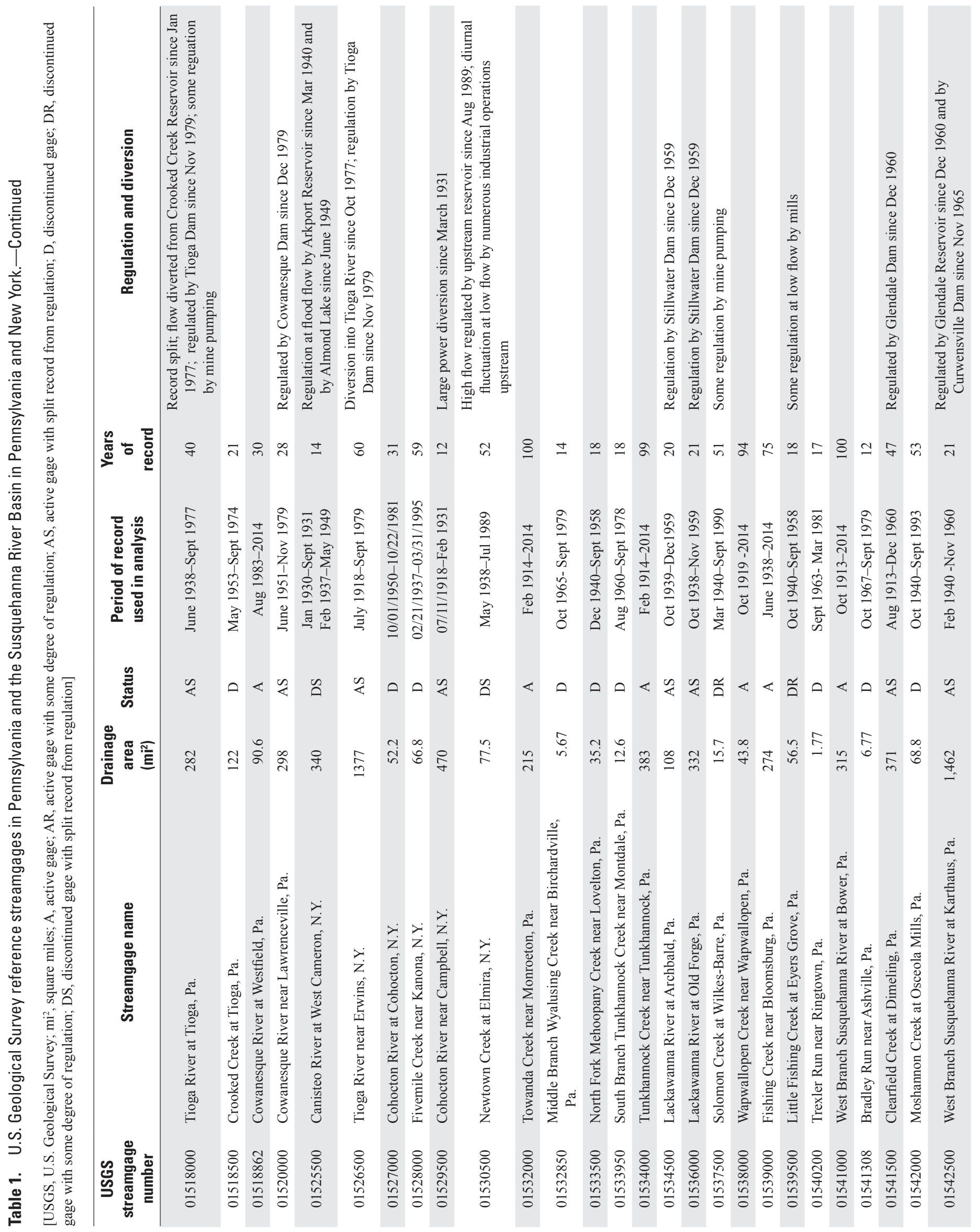




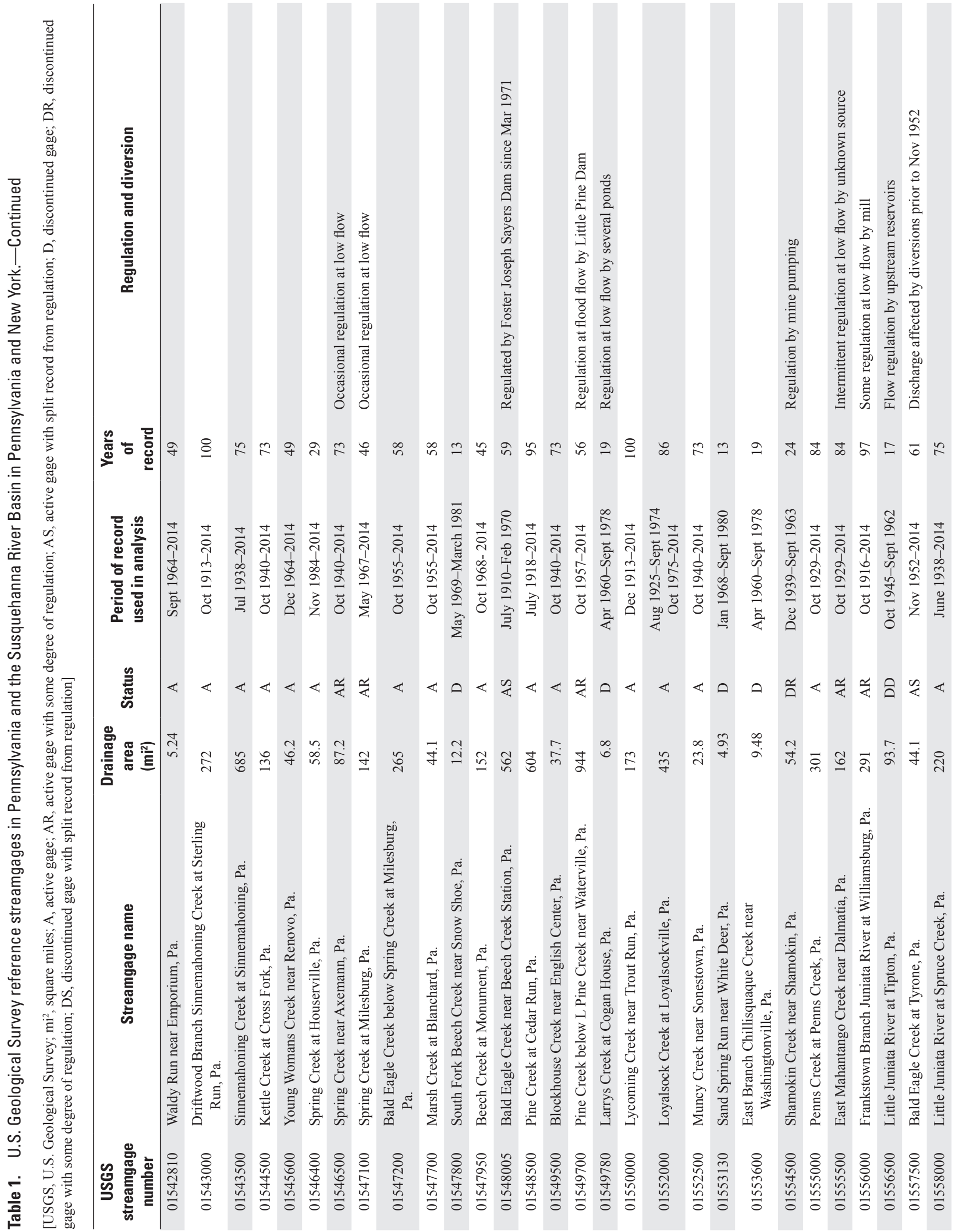




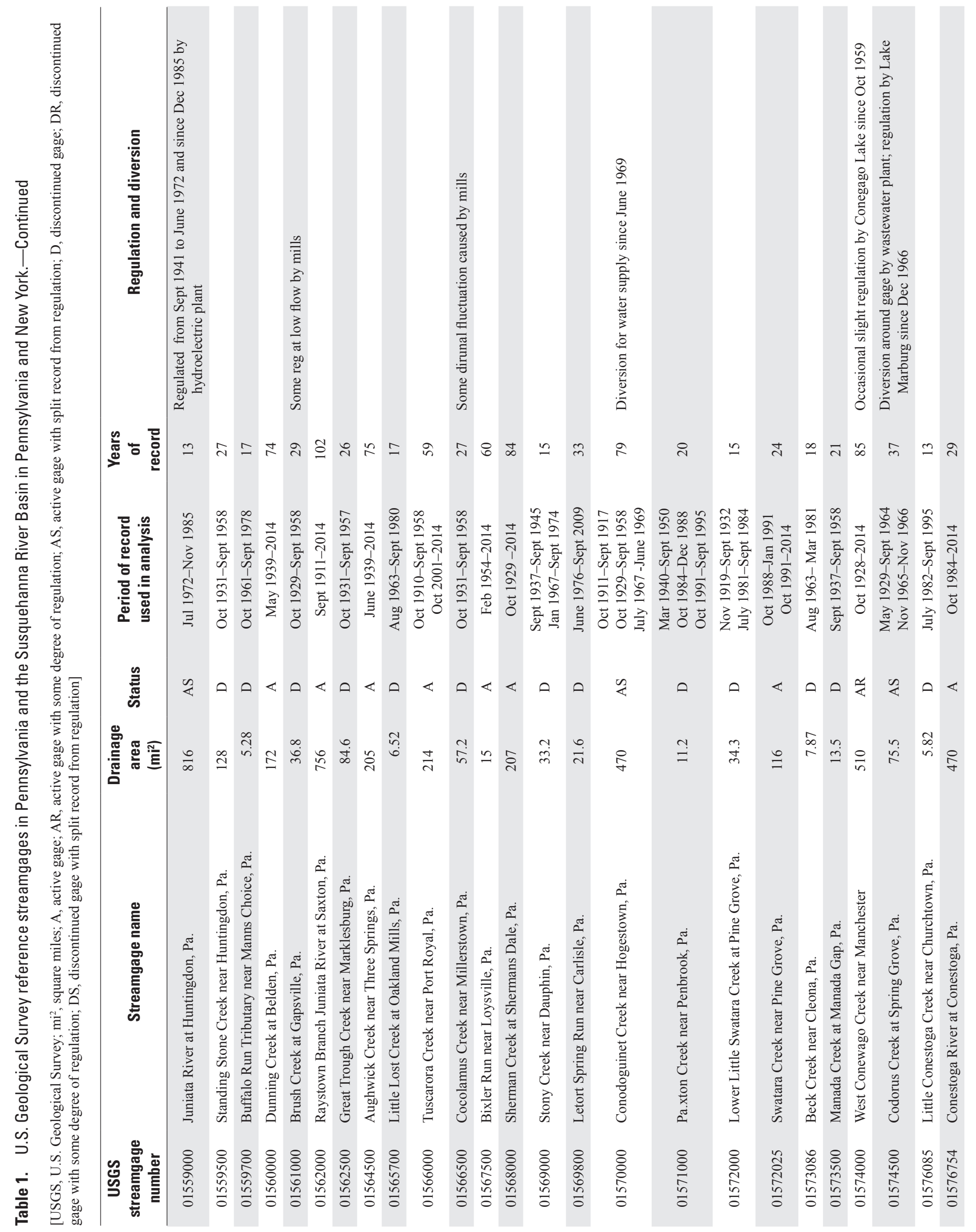




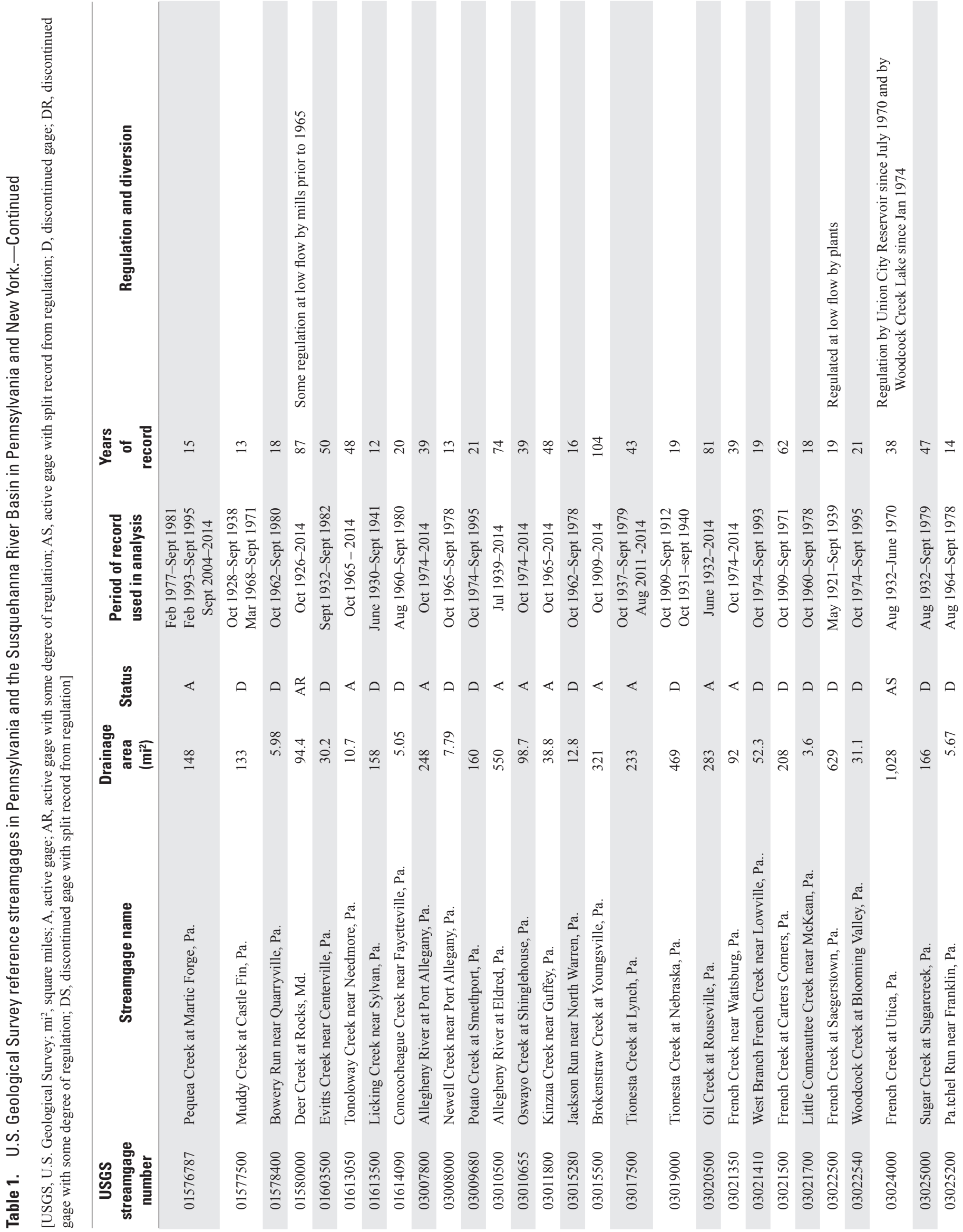




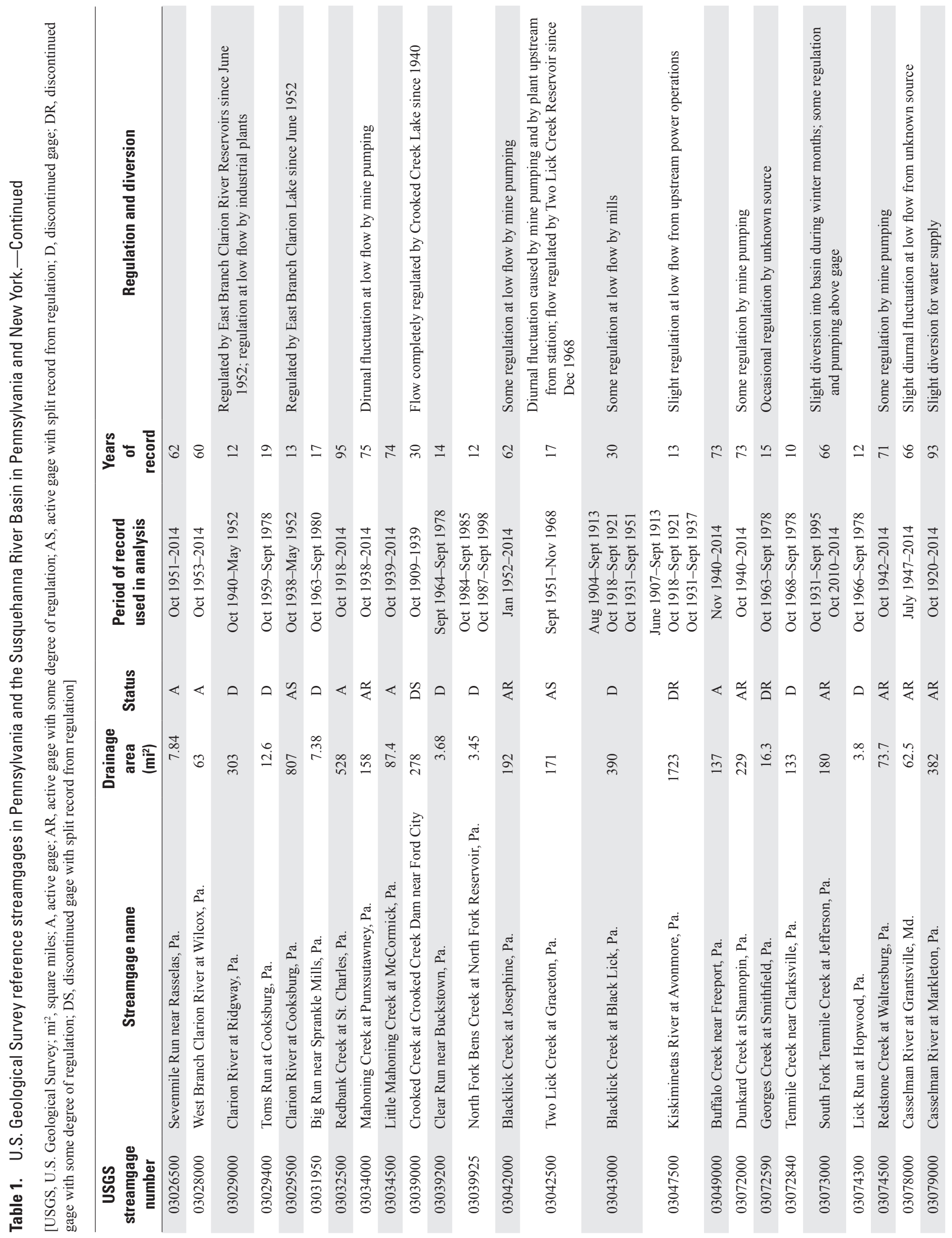




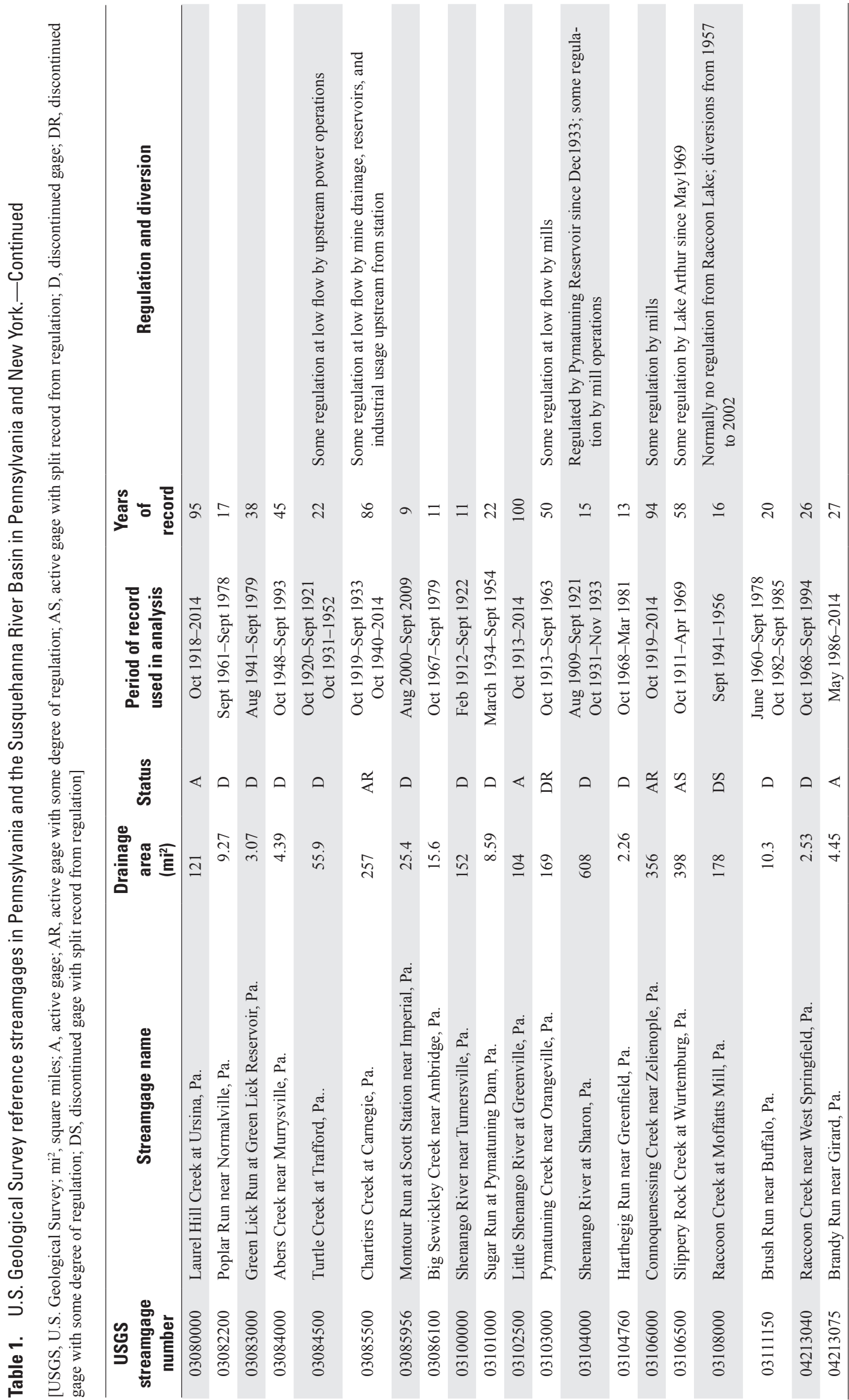




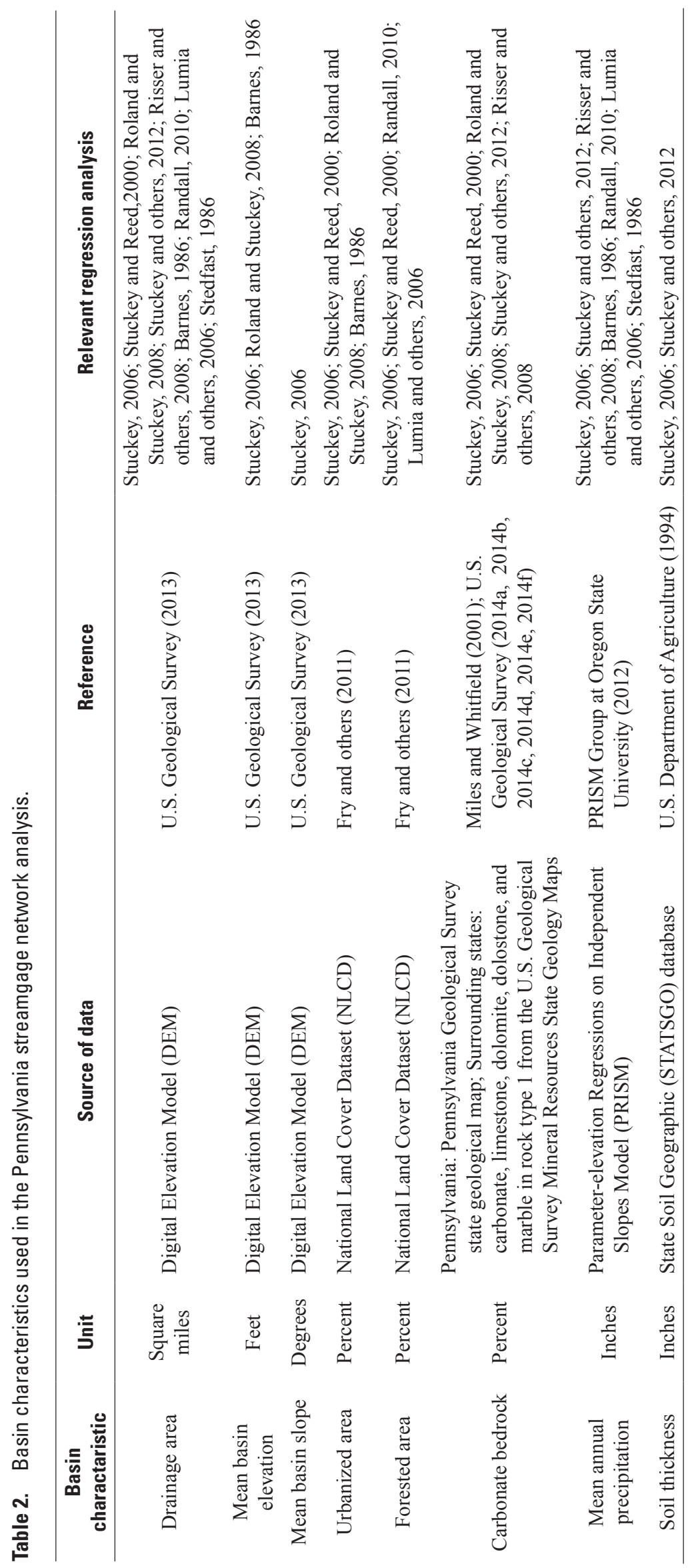


contributing area. Ranges of basin characteristic values and the distribution of the values were compared for each dataset.

A matrix plot showing the relations between all the basin characteristics determined for the reference streamgage watersheds is shown in figure 2. Many of these relations are expected, such as forested area increases as mean elevation increases, or that watersheds with large drainage areas have lower percentages of urbanized area (because as the drainage area increases, the more likely it is that land uses will be mixed and not uniformly high in urbanized area). These plots may provide insight into possible deficiencies in the combinations of basin characteristics. Examples of deficiencies are the narrow range for soil thickness in drainage basins greater than $500 \mathrm{mi}^{2}$ and the narrow range for precipitation in watersheds with urban area greater than 40 percent. Matrix plots for the Delaware, Susquehanna and Potomac, and Ohio and Saint Lawrence River Basins are shown in Appendix 1. Although these relations are not analyzed further in this report, their use would be beneficial when siting a new reference streamgage.
Comparisons of the ranges of basin characteristics between reference streamgage watersheds and HUC12 subwatersheds were made to determine whether the reference streamgages adequately represent the range of basin characteristics found in the HUC12 subwatersheds. If the basin characteristic value determined for a HUC12 subwatershed was outside the range of basin characteristic values determined for the reference streamgages, then the HUC12 subwatershed was not considered to be represented by a reference streamgage and was identified as a potential gap. For streamgage watersheds that encompass more than one HUC12 watershed, or for streamgage watersheds that are very small and do not encompass an entire HUC12 watershed, this comparison may not be entirely equivalent.

Overall, the reference gages represent 81 percent of the range in the selected basin characteristics of the HUC12 subwatersheds. Within the Delaware River Basin, Susquehanna/ Potomac River Basins, and the Ohio/Saint Lawrence River Basins, the reference streamgages represent 79 percent,

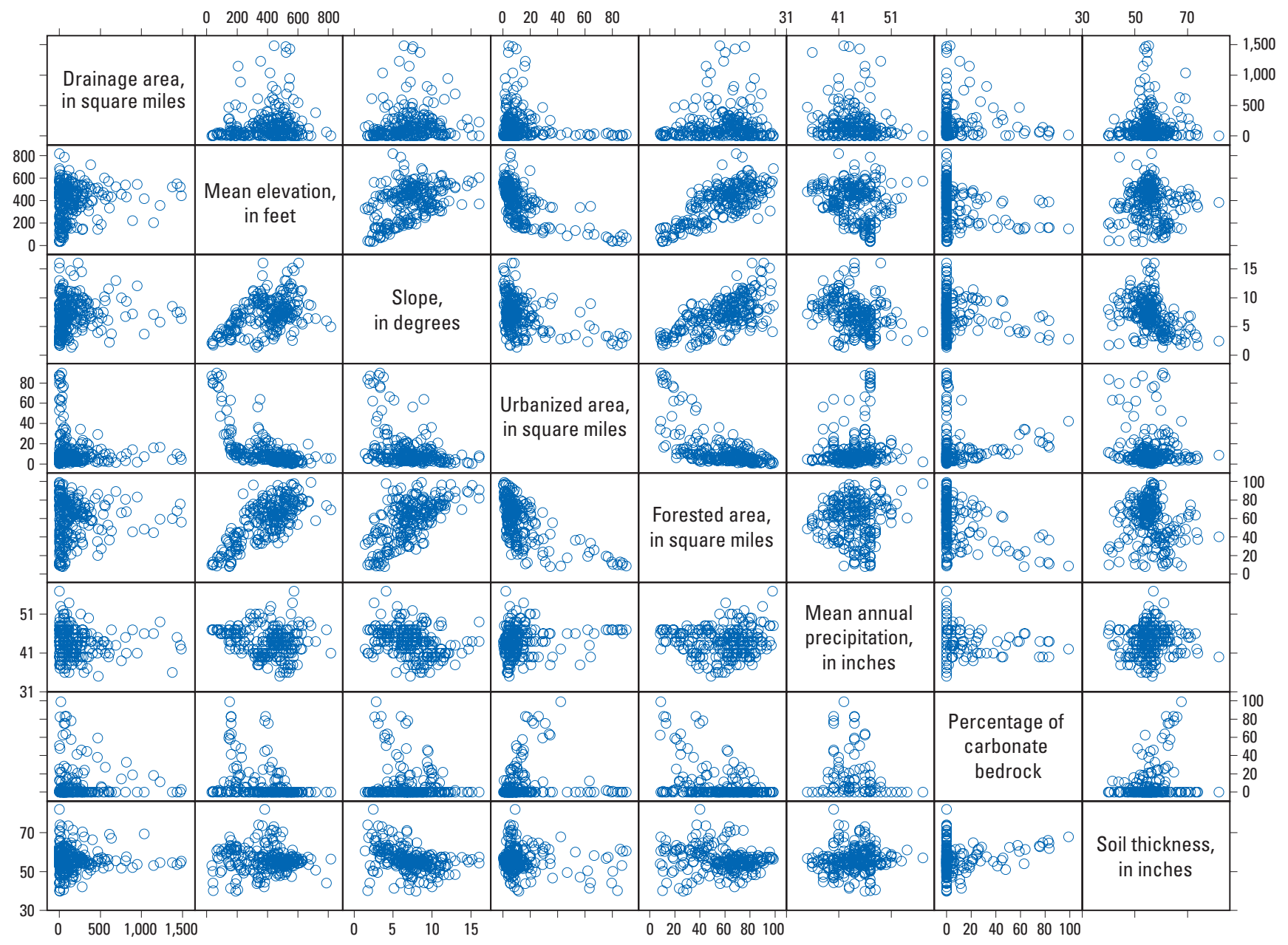

Figure 2. Comparison of basin characteristics for reference streamgages in Pennsylvania and New York. 
78 percent, and 87 percent, respectively, of the range of basin characteristics found within the HUC12 subwatersheds (figs. 3-5). A total of 320 HUC12 subwatersheds, or 19 percent, in the study area had basin characteristics outside the range represented by the reference gages. Detailed analyses of each of the selected basin characteristics are in the sections that follow. A consistent theme throughout this analysis is a lack of representation of basin characteristics for watersheds in headwaters of larger rivers. The large number of headwater streams within Pennsylvania and the Susquehanna River Basin, and the unique set of basin characteristics within each of the small watersheds, can make finding a representative reference streamgage challenging.

\section{Drainage Area}

Drainage area is a fundamental physical characteristic of a watershed. It is commonly used to classify watersheds and is the basis on which many other watershed characteristics are calculated. For example, the percentage of basin covered by forest is computed in relation to the drainage area of the watershed. Overall, drainage areas for the 229 reference streamgages in the study area range from 1.80 to $1,485 \mathrm{mi}^{2}$ with a mean of $185 \mathrm{mi}^{2}$ (table 3 ). When grouped into the three major river basins (fig. 6), similar patterns emerge for the basins, with the largest number of reference streamgages in the range of $50 \mathrm{mi}^{2}$ to $150 \mathrm{mi}^{2}$. The Ohio River Basin has the most reference streamgages with drainage areas of $5 \mathrm{mi}^{2}$ or less (fig. 6). Overall in the study area, reference streamgages are on 49 headwaters streams with drainage areas less than $15 \mathrm{mi}^{2}$, which accounts for 21 percent of the reference streamgage watersheds. Because the areas of individual HUC12 subwatersheds do not include any contributing area upstream, a comparison of area was not done between HUC12 subwatersheds and reference streamgage watersheds.

\section{Mean Basin Elevation}

Mean basin elevation was computed as an area-weighted average from the USGS national elevation dataset (U.S. Geological Survey, 2013a). Mean basin elevations for the reference streamgage watersheds in the study area range from 34.9 to 818 feet (ft). Mean basin elevations for the HUC12 subwatersheds range from 5.49 to $779 \mathrm{ft}$ (table 3). A comparison of mean basin elevations for the reference streamgage and $\mathrm{HUC1} 2$ subwatersheds (fig. 7A) shows that 90 percent of the mean basin elevations for the HUC12 subwatersheds fall within the range for the reference streamgage watersheds. The overall distributions of mean basin elevations observed within the HUC12 subwatersheds and the reference streamgage watersheds are similar (fig. 8A). Although there are fewer reference streamgages in the range of $200-300 \mathrm{ft}$, and above $700 \mathrm{ft}$, the reference streamgage watershed mean basin elevations correspond to the distribution found in the HUC12 subwatersheds.
Within the Delaware River Basin, there are 12 HUC12 subwatersheds with mean basin elevations outside of the range for the reference streamgage watersheds within the Delaware River Basin (fig. 3). The 12 watersheds are in the Philadelphia area along the Delaware River. Within the Susquehanna and Potomac River Basins, there are 41 HUC12 subwatersheds with mean basin elevations outside the range for the reference streamgages within the Susquehanna and Potomac River Basins (fig. 4). These watersheds are generally within the lower Susquehanna River Basin and flow directly into the main stem Susquehanna River. Within the Ohio and Saint Lawrence River Basins, there are three HUC12 subwatersheds with mean basin elevations outside the range for the reference streamgage watersheds within the Ohio and Saint Lawrence River Basins (fig. 5). The three watersheds are within the Saint Lawrence River Basin and adjacent to Lake Erie in the northwestern corner of the Pennsylvania.

\section{Mean Basin Slope}

Mean basin slope was computed as area-weighted mean from the USGS National Elevation Dataset (U.S. Geological Survey, 2013a). Mean basin slope for the reference streamgage watersheds in the study area ranges from 1.4 to 16.1 degrees. Mean basin slope for the HUC12 subwatersheds ranges from 0.14 to 19 degrees (table 3 ). A comparison of mean basin slope between the reference streamgages and HUC12 subwatersheds (fig. 7B) shows that 96 percent of the mean basin slopes for the HUC12 subwatersheds falls within the range for the reference streamgage watersheds. The overall distribution of mean basin slope values observed within the HUC12 subwatersheds and the reference streamgage watersheds are similar (fig. 8B).

Overall, there is greater density of reference streamgage watersheds than of HUC12 subwatersheds with lower (less than 8 degrees) mean basin slope and a lesser density of reference streamgage watersheds than of HUC12 subwatersheds with higher (greater than 8 degrees) mean basin slope. There are no reference watersheds with a slope of 1 degree or less.

Within the Delaware River Basin, there are 18 HUC12 subwatersheds with mean basin slope outside of the range represented by reference streamgages within the Delaware River Basin (fig. 3). The watersheds are in the central part of the basin, characterized by moderate to high relief, and in the Philadelphia area along the Delaware River, characterized by low relief. Within the Susquehanna and Potomac River Basins, there are $27 \mathrm{HUC} 12$ subwatersheds with mean basin slope outside of the range for reference streamgage watersheds within the Susquehanna and Potomac River Basins (fig. 4). These watersheds generally are in the headwaters of the West Branch Susquehanna River where the high mean basin slope is a direct result of the high basin elevation and relief found there. A few isolated watersheds in the lower Susquehanna River Basin have mean basin slope values smaller than the range for the reference streamgages. Within the Ohio and Saint Lawrence River Basins, there are 15 HUC12 subwatersheds with mean basin slope values outside the range for the 


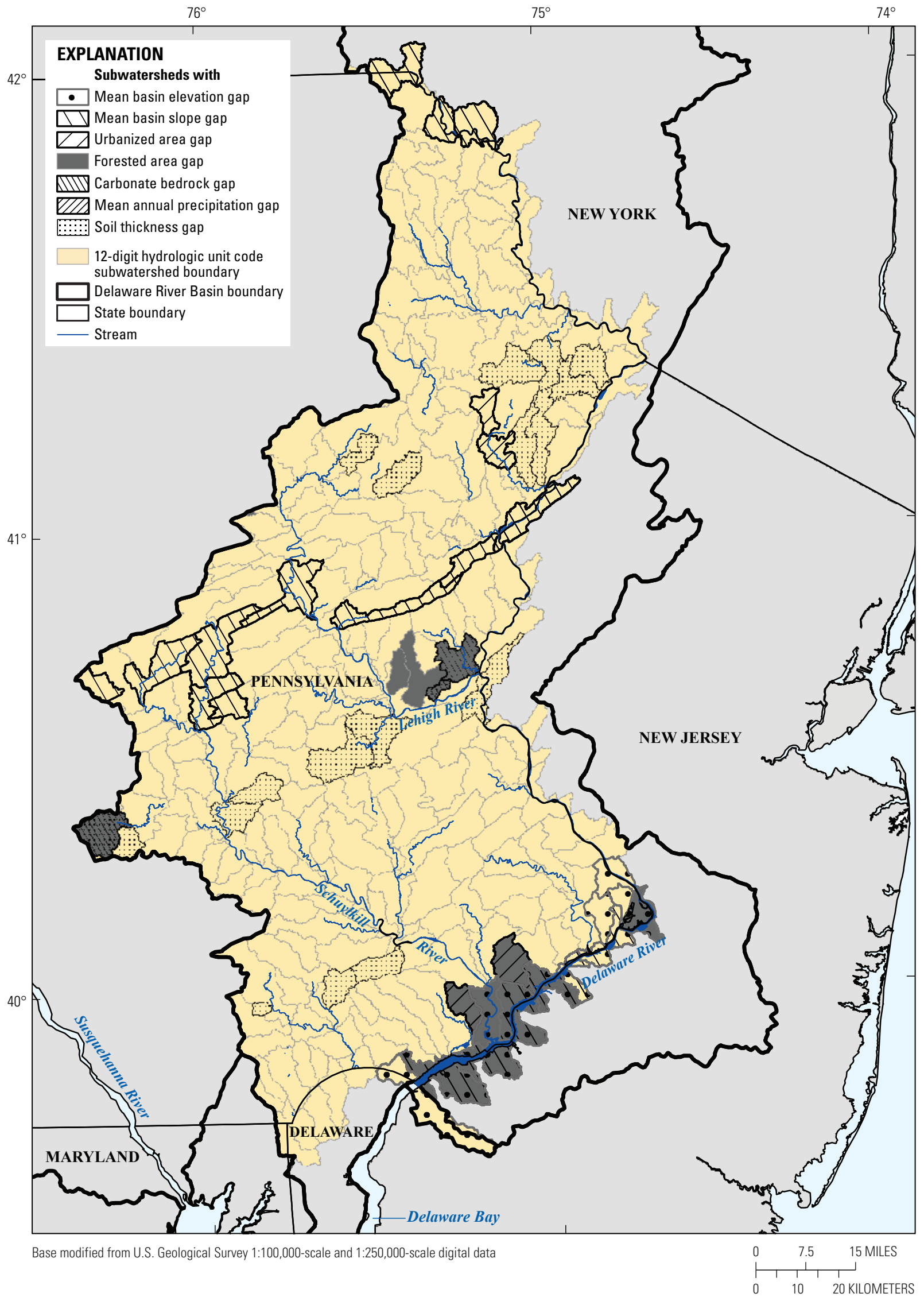

Figure 3. Basin characteristic gaps in the Delaware River Basin. 


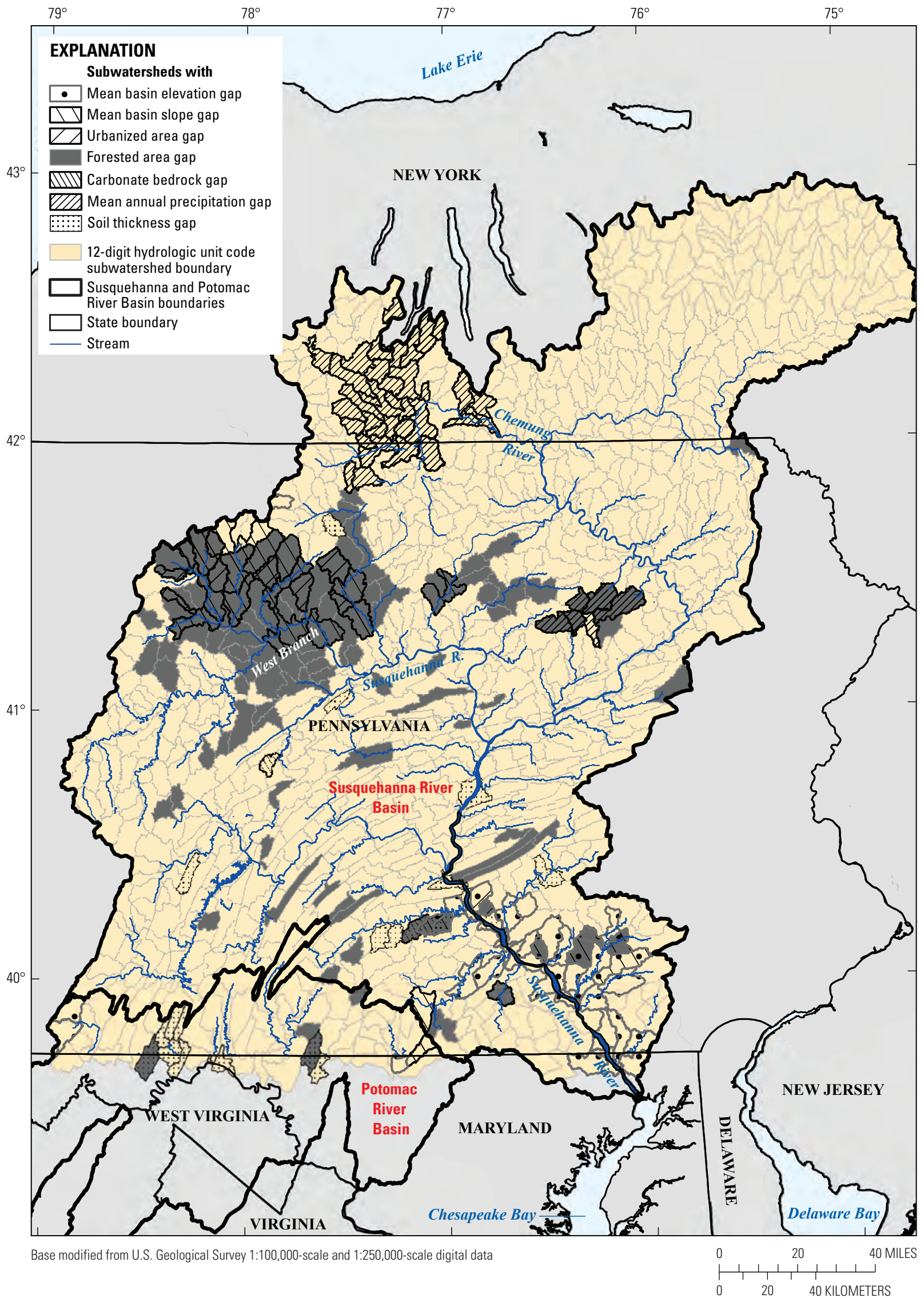

Figure 4. Basin characteristic gaps in the Susquehanna River Basin. 


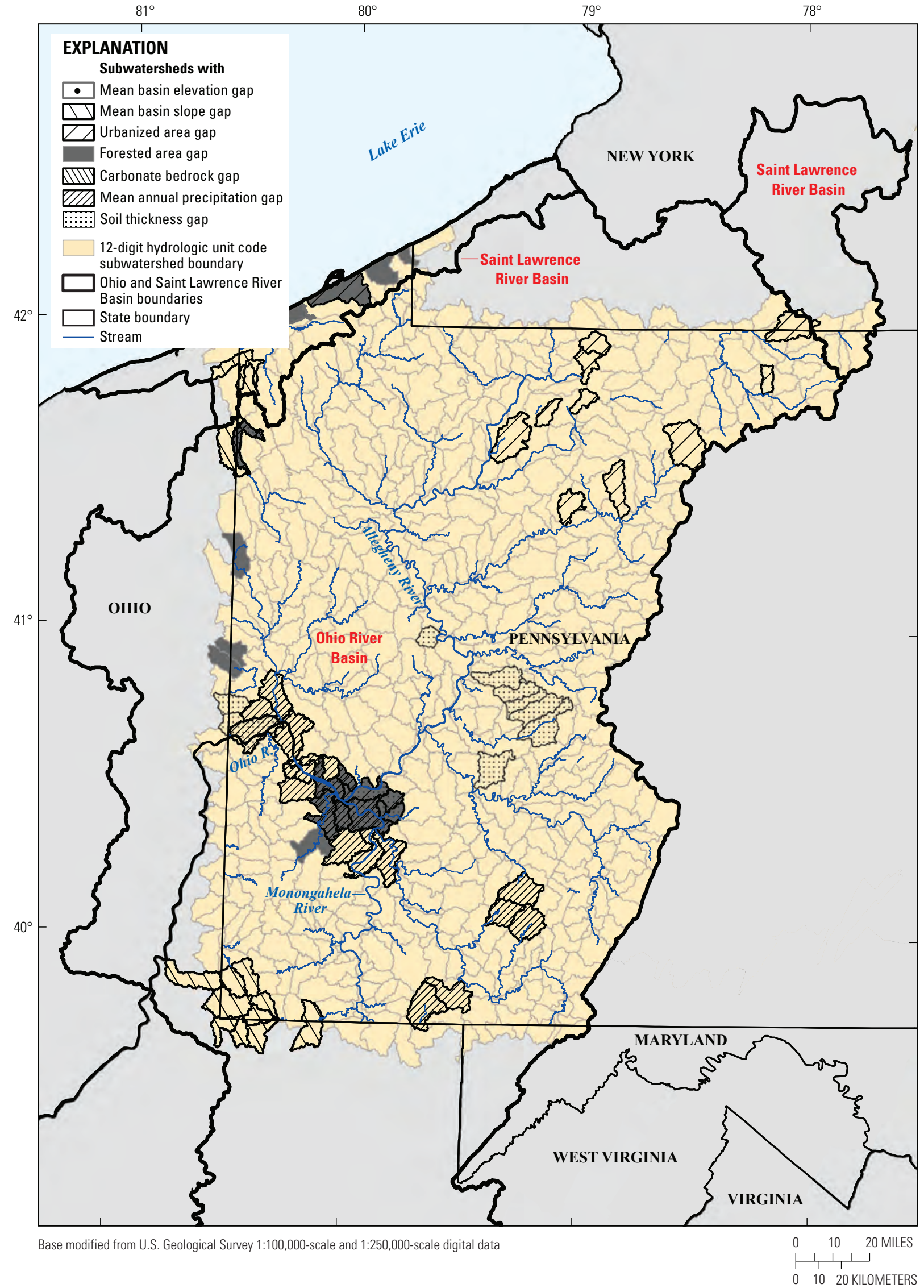

Figure 5. Basin characteristic gaps in the Ohio River Basin. 


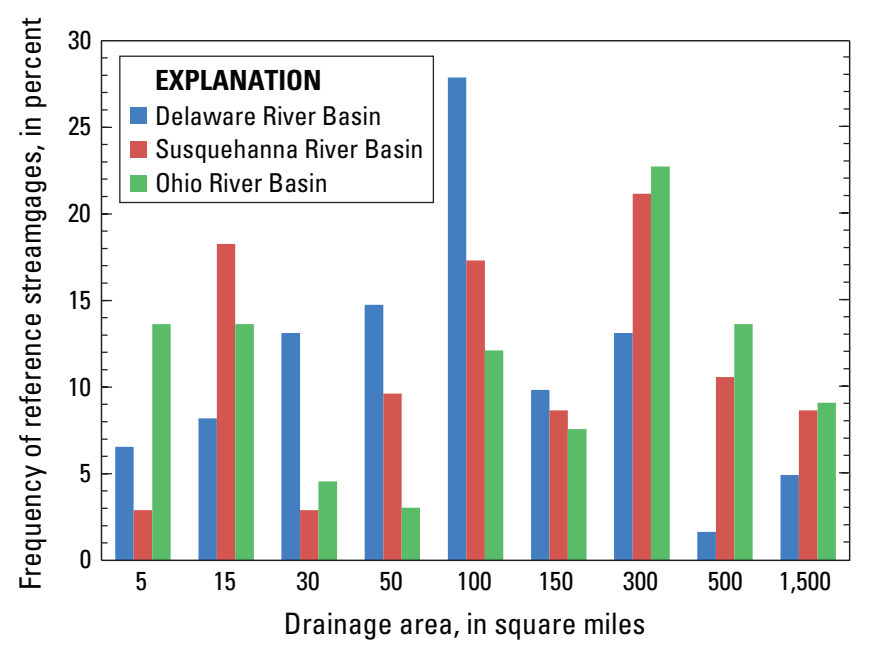

Figure 6. Drainage area of reference streamgages in the Delaware River, Susquehanna River, and Ohio River Basins.

reference streamgage watersheds within the Ohio and Saint Lawrence River Basins (fig. 5). The watersheds are present in the southwestern corner of the State and are characterized by high mean basin slope. In the Saint Lawrence River Basin, watersheds are characterized by low mean basin slope.

\section{Percentage of Urbanized Area}

The percentage of urbanized area was determined from the 2006 National Land Cover Dataset (NLCD; Fry and others, 2011). Percentage of urbanized area was determined by summing the four developed land classifications in the NLCD - developed open space, developed low intensity, developed medium intensity, and developed high intensity. Most of Pennsylvania is rural; the mean percentage of urbanized area was 13.4 for the reference streamgage watersheds and 11.4 for the HUC12 subwatersheds (table 3 ). The percentage of urbanized area exceeded 20 percent in 14.5 percent of the reference streamgage watersheds and 13.5 percent in the HUC12 subwatersheds. The percentage of urbanized area for the reference streamgage watersheds ranged from 0.36 to 90.1. A comparison of urbanized area between the reference streamgage and HUC12 subwatersheds (fig. 7C) shows that 98 percent of the urbanized area found within the HUC12 subwatersheds is within the range representing the reference streamgage watersheds. The distribution of percentage of urbanized area is greatest towards the lower end of the range (fig. 8C).

Within the Delaware River Basin, there are four HUC12 subwatersheds with percentage of urbanized area outside the range for the reference streamgage watersheds within the Delaware River Basin (fig. 3). The watersheds are in the northeastern part of the basin characterized by low percentages of urbanized area and in the Philadelphia area characterized by high percentages of urbanized area. Within the Susquehanna and Potomac River Basins, there are 10 HUC12 subwatersheds with percentage of urbanized area outside the range for reference streamgage watersheds within the Susquehanna and Potomac River Basins, which are mostly within the heavily forested headwaters of the West Branch Susquehanna River (fig. 4). Some HUC12 subwatersheds are outside the upper range of percentage of urbanized area in the cities of Harrisburg and York, Pa, in the south-central part of the Susquehanna River Basin. Within the Ohio and Saint Lawrence River Basins, there are 19 HUC12 subwatersheds with percentage of urbanized area outside the range for reference streamgage watersheds within the Ohio and Saint Lawrence River Basins (fig. 5). Most of these watersheds are in the headwaters of the Allegheny River and have low percentages of urbanized area. In the greater Pittsburgh area and Erie, Pa., HUC12 subwatersheds have high percentages of urbanized area.

\section{Percentage of Forested Area}

The percentage of forested area was determined from the 2006 NLCD (Fry and others, 2011). Percentage of forested area was determined by summing the three forest land classifications in the NLCD - deciduous forest, evergreen forest, and mixed forest. The percentage of forested area for the reference streamgage watersheds ranged from 8.25 to 98.8 . The percentage of forested area for the HUC12 subwatersheds ranged from 1 to 98.8 percent (table 3). A comparison of percentage of forested area between the reference streamgage and HUC12 subwatersheds (fig. 7D) shows that 91 percent of the forested area found within the HUC12 subwatersheds is within the range for the reference streamgage watersheds. The distribution of percentage of forested area is skewed towards the upper end of the range (fig. 8D). The overall distribution of percentage of forested area observed within the HUC12 subwatersheds and the reference streamgage watersheds is similar, although differences can be seen throughout the plot (fig. 8D). There are no reference streamgage watersheds with percentage of forested area less than 8 , and the reference streamgage density in forested areas is less than that within the HUC12 subwatersheds, in the range of 40-50 percent forested area.

Within the Delaware River Basin, there are 13 HUC12 subwatersheds with percentage of forested area outside the lower range for reference streamgage watersheds within the Delaware River Basin. These watersheds are mostly near the cities of Allentown, $\mathrm{Pa}$., in the central part of the basin and Philadelphia, Pa., in the southeast. Within the Susquehanna and Potomac River Basins, there are 115 HUC12 subwatersheds with percentage of forested area outside the range for the reference streamgage watersheds within the Susquehanna and Potomac River Basins. Most of these watersheds are within the highly forested area in the headwaters of West Branch Susquehanna River in the north-central part of the 


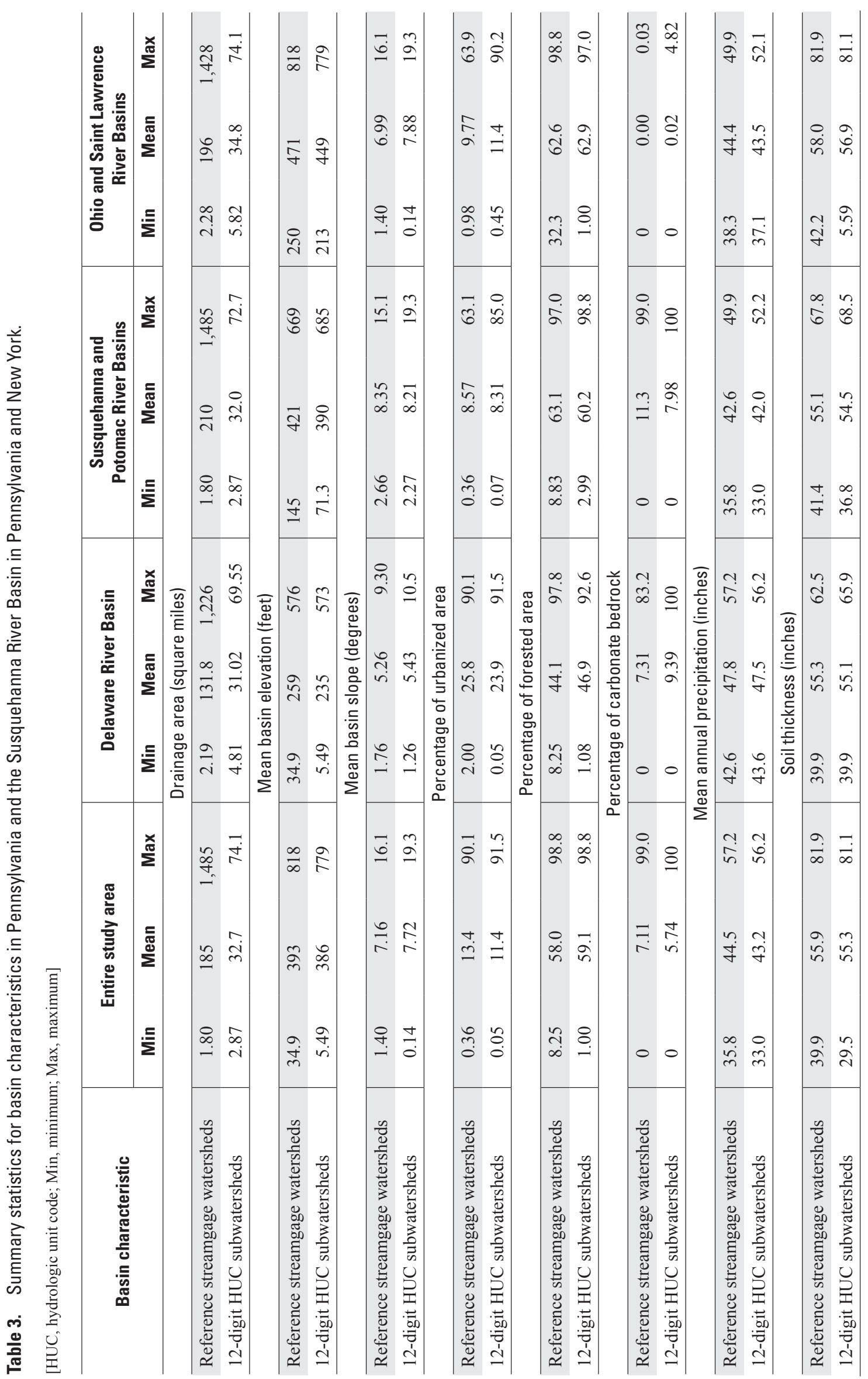



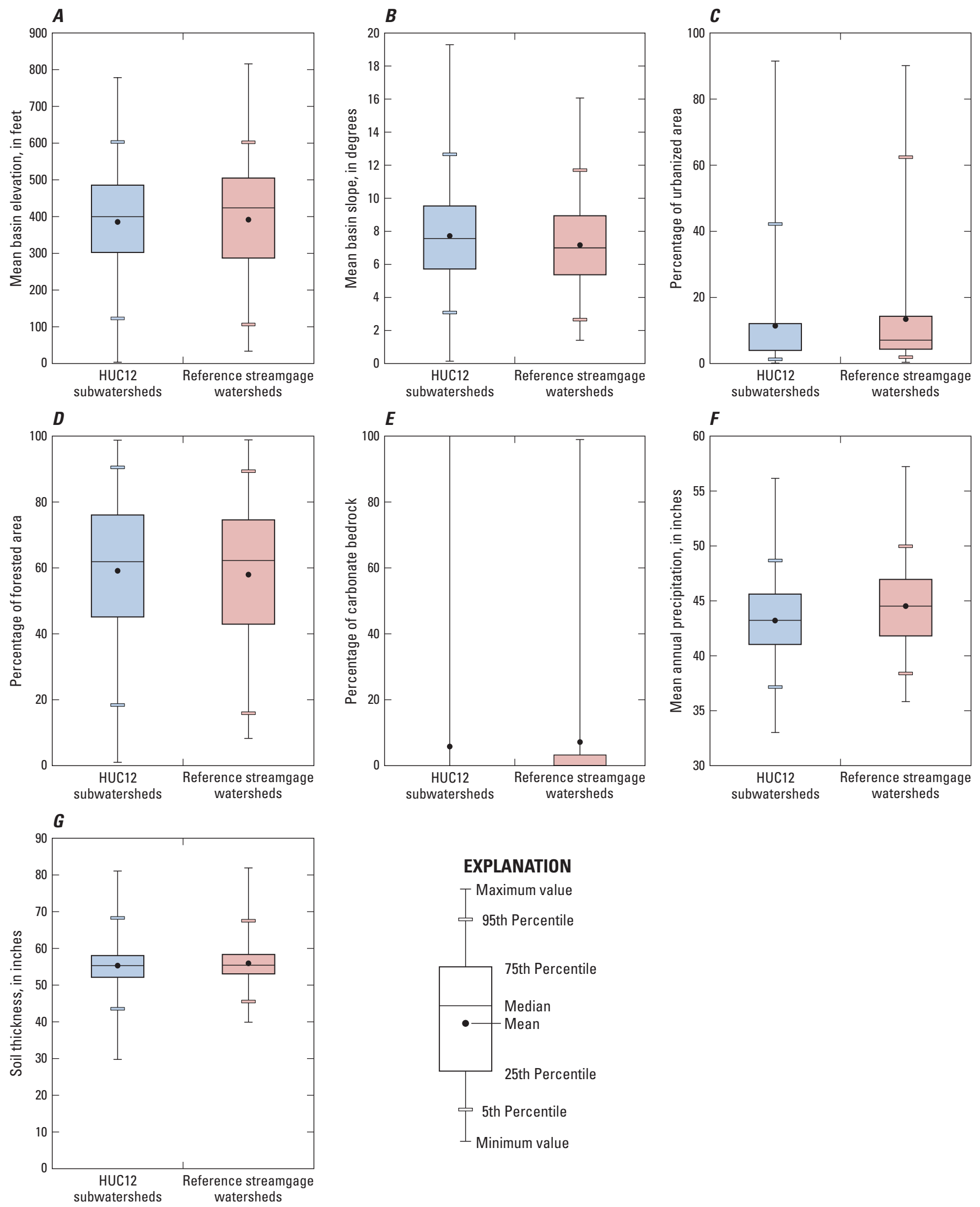

Figure 7. Box plots showing the distribution of $A$, mean basin elevation, $B$, mean basin slope, $C$, percentage of urbanized area, $D$, percentage of forested area, $E$, percentage of carbonate rock, $F$, mean annual precipitation, and $G$, soil thickness for reference streamgage and 12-digit hydrologic unit code subwatersheds in Pennsylvania and New York. 

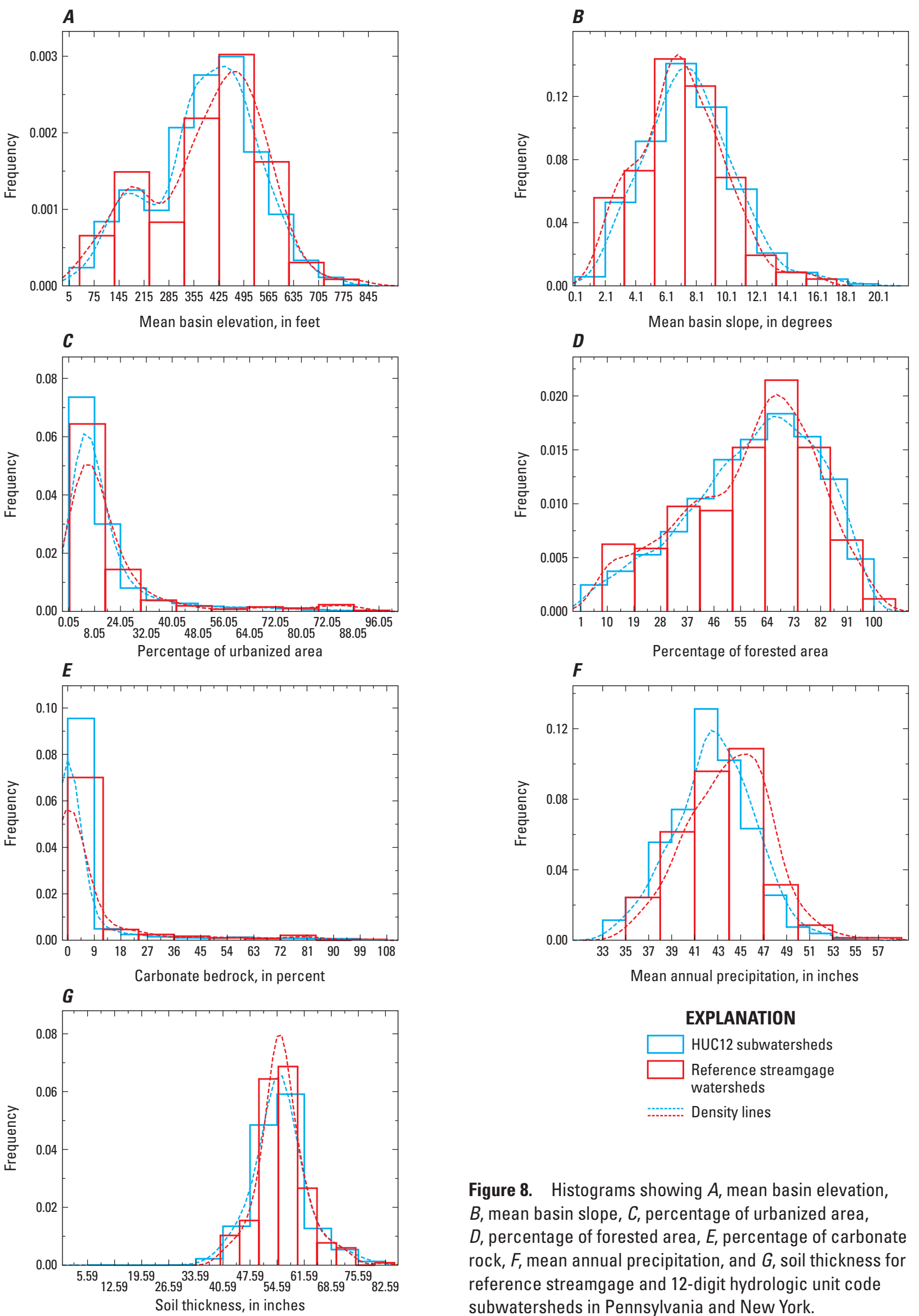

\section{EXPLANATION}

HUC12 subwatersheds

Reference streamgage watersheds

-..-.-.-.- Density lines

Figure 8. Histograms showing $A$, mean basin elevation, $B$, mean basin slope, $C$, percentage of urbanized area, $D$, percentage of forested area, $E$, percentage of carbonate rock, $F$, mean annual precipitation, and $G$, soil thickness for reference streamgage and 12-digit hydrologic unit code subwatersheds in Pennsylvania and New York. 
State. The remaining watersheds are scattered throughout the lower Susquehanna Basin and Potomac Basin. Within the Ohio and Saint Lawrence River Basins, there are 16 HUC12 subwatersheds with percentage of forested area outside the range for the reference streamgage watersheds within the Ohio and Saint Lawrence River Basins. These HUC12 subwatersheds are generally in the greater Pittsburgh, Pa., area and the Saint Lawrence River Basin.

\section{Percentage of Carbonate Bedrock}

The percentage of each basin underlain by carbonate rock was computed using geologic maps (table 2). The percentages of carbonate rock for the reference streamgage watersheds ranged from 0 to 99 . The percentages of carbonate rock for the HUC12 subwatersheds ranged from 0 to 100 (table 3). A comparison of percentage of carbonate bedrock between the reference streamgage and HUC12 subwatersheds (fig. 7E) shows that 99 percent of the carbonate bedrock values found within the HUC12 subwatersheds are within the range for the reference streamgage watersheds. A comparison of percentage of carbonate rock between the reference streamgage and HUC12 subwatersheds (fig. 8E) shows that the distribution is greater towards the low end.

Within the Delaware River Basin, there are $3 \mathrm{HUC12}$ subwatersheds with percentage of carbonate bedrock outside the range for the reference streamgage watersheds within the Delaware River Basin; all 3 HUC12 subwatersheds are near the mouth of the Lehigh River and headwaters of the Schuylkill River. Within the Susquehanna and Potomac River Basins, there are three HUC12 subwatersheds with percentage of carbonate bedrock outside the range for reference streamgage watersheds within the Susquehanna and Potomac River Basins. These HUC12 subwatersheds are in the central and south-central parts of the State. Within the Ohio and Saint Lawrence River Basins, there are no HUC12 subwatersheds with percentage of carbonate bedrock outside the range for the reference streamgage watersheds within the Ohio and Saint Lawrence River Basins.

\section{Mean Annual Precipitation}

Mean annual precipitation was estimated from the Precipitation-Elevation Regressions on Independent Slopes Model (PRISM) (PRISM Group, Oregon State University, 2012). The mean annual precipitation for the reference streamgage watersheds ranged from 35.8 to 57.2 inches per year (in/yr). The mean annual precipitation for the HUC12 subwatersheds ranged from 33.0 to $56.2 \mathrm{in} / \mathrm{yr}$ (table 3).

Overall, 96 percent of the mean annual precipitation values found within the HUC12 subwatersheds are within the range for the reference streamgage watersheds. A comparison of mean annual precipitation values between the reference streamgage and HUC12 subwatersheds (fig. 7F) shows that the reference streamgage watersheds have higher mean and median values than the HUC12 subwatersheds and do not encompass the lower range of HUC12 subwatershed mean annual precipitation values, which can be seen by the shape of the density lines in figure $8 \mathrm{~F}$. The reference streamgage watersheds do not have any mean annual precipitation values less than $35 \mathrm{in} / \mathrm{yr}$

(fig. 8F).

Within the Delaware River Basin, no HUC12 subwatershed has mean annual precipitation outside the range for the reference streamgage watersheds within the Delaware River Basin. Within the Susquehanna and Potomac River Basins, there are 40 HUC12 subwatersheds with mean annual precipitation outside the range for the reference streamgage watersheds within the Susquehanna and Potomac River Basins. Most of these watersheds are in the Chemung River subbasin in New York and northern Pennsylvania; a few are in the northeastern part of the basin. Within the Ohio and Saint Lawrence River Basins, there are 22 HUC12 subwatersheds with mean annual precipitation outside the range for the reference streamgage watersheds within the Ohio and Saint Lawrence River Basins. Most HUC12 subwatersheds are located along the main stem of the Ohio and Monongahela Rivers.

\section{Soil Thickness}

Soil thickness was estimated from the state soil geographic (STATSGO) digital dataset (U.S. Department of Agriculture, 1994). The soil thickness for the reference streamgage watersheds ranged from 39.9 to $81.9 \mathrm{in}$. The soil thickness for the HUC12 subwatersheds ranged from 29.5 to 81.1 inches (in; table 3). A comparison of soil thickness between the reference streamgage and HUC12 subwatersheds (fig. 7G) shows that 97 percent of the mean soil thickness within the HUC12 subwatersheds is within the range for the reference streamgage watersheds. Although the mean and median soil thicknesses for the reference streamgage and HUC12 subwatersheds are very similar, the range of soil thickness values determined for the reference streamgage watersheds do not encompass the lower range of HUC12 subwatershed soil thickness values (figs. 7G and 8G).

Within the Delaware River Basin, there are $19 \mathrm{HUC12}$ subwatersheds with soil thickness outside the range for the Delaware River Basin reference streamgage watersheds. The HUC12 subwatersheds are mostly in small groups throughout the basin. Within the Susquehanna and Potomac River Basins, there are 19 HUC12 subwatersheds with soil thickness outside the range for the reference streamgage watersheds within the Susquehanna and Potomac River Basins. These watersheds are scattered throughout the Susquehanna Basin and the Potomac Basin. Within the Ohio and Saint Lawrence River Basins, there are 17 HUC12 subwatersheds with soil thickness outside the range for the reference streamgage watersheds within the Ohio and Saint Lawrence River Basins. Most of these watersheds are in the proximity of Pittsburgh, Pa., and in the central part of the basin. 


\section{Identification of Geographic Gaps}

A GIS spatial analysis was used to identify geographic gaps in the reference streamgage network. For each streamgage, a watershed area, defined as the gage statistical area (GSA), was delineated. The GSA shows the watershed area applicable for transfer of streamflow statistics from the streamgage to an ungaged site, defined as the valid statistical reach (VSR) of the GSA for a streamgage (fig. 9). The VSR is defined by the proximity to the streamgage. Flow statistics at the streamgage can be considered transferrable to any point on the VSR, assuming the basin characteristics are similar at the streamgage and ungaged site. The transfer of streamflow statistics from a streamgage to an ungaged site on the VSR is typically done using the drainage-area ratio method.

\section{Drainage-Area Ratio Method}

To define the extent of the VSR, an analysis was done to determine the appropriate extent to which statistics could be transferred using the drainage-area ratio method. The drainage-area ratio method assumes that the streamflow at an ungaged site is the same per unit area as that at a nearby, hydrologically similar streamgage. Streamflow statistics are first computed for the streamgage site, then the streamflow statistics are divided by the drainage area to determine streamflow statistic per unit area at the streamgage. This streamflow statistic per unit area value is multiplied by the drainage area at the ungaged site to obtain estimated streamflow statistics for the ungaged site. This method is most commonly applied when the streamgage is on the same stream as the ungaged site

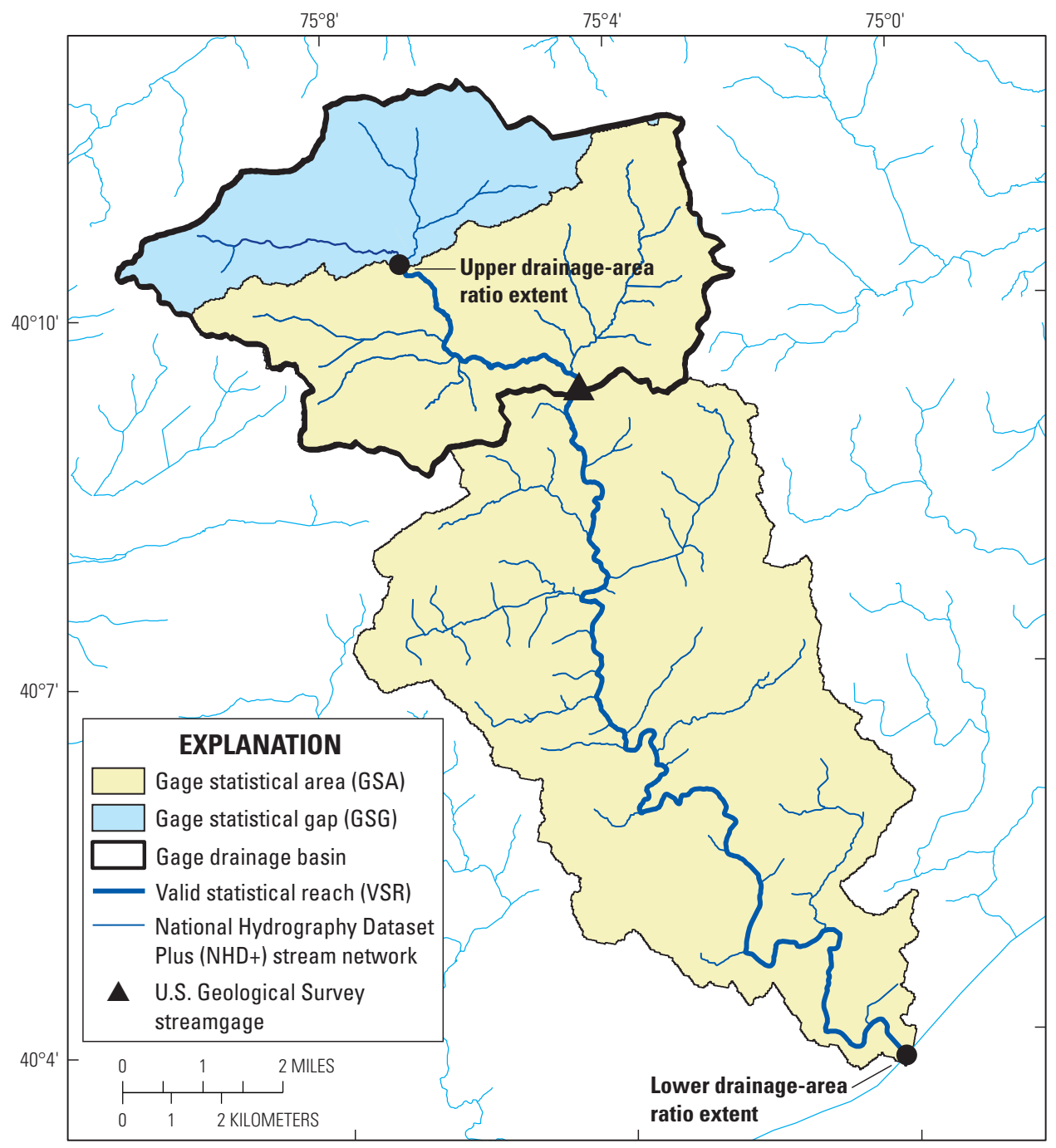

Figure 9. Gage statistical area and valid statistical reach for an example watershed. 
because the accuracy of the method depends on the proximity of the two, on similarities in drainage area, and on the basin characteristics of their drainage basins (Ries and Friesz, 2000). Various studies have suggested different drainage-area ratio criteria for applying this method, but the standard ratio has been 0.5 to 1.5 or 2.0 times the drainage area of a streamgage (Choquette, 1988; Bisese, 1995; Ries and Friesz, 2000; Roland and Stuckey, 2008). A ratio in the range of 0.33-3 has been suggested for the transfer of low-flow statistics in Pennsylvania (R.E. Thompson, Jr., U.S. Geological Survey, written commun., 1999).

To determine the extent to which the drainage-area ratio method can be successfully applied upstream and downstream from a streamgage, 51 unique pairs of streamgages in Pennsylvania were evaluated (Appendix 2). Both streamgages in each pair are in the same watershed and have 10 or more years of streamflow data. Some streamgages were used multiple times in different pairs. The drainage areas of streamgages range from $4.78 \mathrm{mi}^{2}$ to $1,462 \mathrm{mi}^{2}$, with a median of $202 \mathrm{mi}^{2}$. Of the 102 streamgages used in the paired datasets, 39 had drainage-area ratios between 0.5 and 1.5, 46 had drainagearea ratios between 0.5 and 2.0, 69 had drainage-area ratios between 0.33 and 3.0, and 33 had drainage-area ratios less than 0.33 and greater than 3.0.

The drainage-area ratio method was used to transfer previously published streamflow statistics (termed "computed") from one gaged site to the other paired gaged site using equation 1 below. The transferred statistics were then compared to the computed statistics for the same streamgage. The period of record used to determine the computed statistics was not necessarily the same for streamgages on the same stream, and a particularly wet or dry period during a short period of record could affect the statistics. The computed statistics used in this analysis include flow duration exceedance probabilities [99-percent exceedance (P99), 95-percent exceedance (P95), 50-percent exceedance (P50), 5-percent exceedance (P5), and 1-percent exceedance (P1)], the 7-day 10-year (7Q10) low flow, and the 1-percent annual exceedance probability flood (commonly referred to as the 100-year flood or Q100); all are found in Stuckey and Roland (2011).

$$
Q_{\text {ungaged }}=\left(D A_{\text {ungaged }} / D A_{\text {gage }}\right) * Q_{\text {gage }}
$$

where

$$
\begin{aligned}
& Q_{\text {ungaged }} \quad \text { is the transferred discharge at the ungaged } \\
& \text { site, in cubic feet per second; } \\
& D A_{\text {ungaged }} \quad \text { is the drainage area at the ungaged site, in } \\
& \text { square miles; } \\
& D A_{\text {gage }} \quad \text { is the drainage area at the gaged site, in square } \\
& \text { miles; and } \\
& Q_{\text {gage }} \quad \text { is the discharge at the gaged site, in cubic feet } \\
& \text { per second. }
\end{aligned}
$$

The transferred and computed statistics were compared graphically and by using the absolute percent difference
(Abs; equation 2) and the Wilcoxon signed-rank test (Helsel and Hirsch, 1992), grouped by various ratios.

$$
\operatorname{Abs}\left(\left(Q_{\text {comp }}-Q_{\text {trans }}\right) / Q_{\text {comp }}\right) * 100
$$

where

$$
\begin{gathered}
Q_{\text {comp }} \quad \begin{array}{l}
\text { is the computed discharge at the gaged site, in } \\
\text { cubic feet per second; and }
\end{array} \\
\text { is the transferred discharge at the gaged site, } \\
\text { in cubic feet per second. }
\end{gathered}
$$

The mean absolute percent differences are shown in table 4, grouped by drainage-area ratios, number of years of record, and drainage area. The complete listing of absolute percent differences is in Appendix 2. The transferred peak flow frequency statistic has the largest overall percent difference, whereas the flow duration exceedances have the lowest overall differences. Peak-flow frequencies are typically a result of a major rain or storm event, which may or may not affect a larger watershed. For most transferred streamflow statistics, the drainage-area ratio $0.33-3.0$ performs as well as, if not better than, the more traditional ratios (table 4). Some of the highest percent differences are found in the $0.5-1.5$ drainage-area ratio range (Appendix 2). These high percent differences are likely the result of short periods of record and (or) differing drainage basin characteristics, such as carbonate bedrock, that can affect streamflow statistics. The mean absolute percent differences for all the transferred statistics in relation to the drainage-area ratio is shown in figure 10. The ratio range of $0.5-2.0$ is shown by the black vertical lines, and the red vertical lines represent the ratio range of $0.33-3.0$. Abnormally high absolute percent differences were not introduced by extending the ratio to $0.33-3.0$ (fig. 10). Individual plots for each transferred statistic are shown in Appendix 3.

Drainage area and period of record were also evaluated. Both drainage area and period of record appear to play an important role in the success of the drainage-area ratio method. Overall, streamgages with short period of records had the highest absolute percent difference regardless of the drainage-area ratio used to transfer the statistics (table 4). Short periods of record were heavily influenced by individual wet or dry episodes during the period the streamgage was in operation, which may result in higher percent differences of transferred statistics if the other paired streamgage did not have a similar period of record. The mean absolute percent differences for all transferred streamflow statistics were plotted against the period of record at the streamgage, and a smoothed curve using local regression (LOESS) was applied (fig. 11). LOESS is a nonparametric smoothing technique that is a generalization of running means (TIBCO Software Inc., 2008). Streamgages with less than 20 years of record had the highest percent differences, and the percent differences remained relatively constant at streamgages with 40 years or more of record (fig. 11). Streamgages with drainage areas greater than $300 \mathrm{mi}^{2}$ had the lowest overall mean absolute percent 
Table 4. Mean absolute percent difference between observed and transferred streamflow statistics using the drainage-area ratio method.

[7Q10, 7-day, 10-year low flow; P99, 99-percent duration exceedance; P95, 95-percent duration exceedance; P50, 50-percent duration exceedance; P05, 5-percent duration exceedance; P01, 1-percent duration exceedance; Q100, 1-percent annual exceedance probability flood]

\begin{tabular}{|c|c|c|c|c|c|c|c|c|}
\hline \multirow{2}{*}{ Grouping } & \multirow{2}{*}{$\begin{array}{c}\text { Number of } \\
\text { streamgages }\end{array}$} & \multicolumn{7}{|c|}{ Mean absolute percent difference of streamflow statistic transferred } \\
\hline & & P99 & P95 & P50 & P05 & P01 & 7010 & 0100 \\
\hline \multicolumn{9}{|c|}{ Drainage-area ratio } \\
\hline $0.5-1.5$ & 39 & 28.2 & 23.9 & 11.8 & 11.2 & 16.1 & 30.2 & 71.5 \\
\hline $0.5-2.0$ & 46 & 28.0 & 23.9 & 13.9 & 11.6 & 16.1 & 29.2 & 65.5 \\
\hline $0.33-3.0$ & 69 & 28.2 & 24.7 & 14.0 & 10.3 & 14.6 & 28.0 & 58.0 \\
\hline Any & 102 & 35.3 & 28.4 & 16.3 & 11.5 & 15.4 & 35.8 & 53.8 \\
\hline \multicolumn{9}{|c|}{ Number of years of record } \\
\hline $10-19$ & 23 & 44.1 & 30.9 & 16.4 & 10.9 & 15.5 & 31.4 & 73.7 \\
\hline $20-30$ & 24 & 35.2 & 28.1 & 19.0 & 10.0 & 15.9 & 42.3 & 66.8 \\
\hline Greater than 30 & 55 & 31.7 & 27.5 & 15.1 & 12.5 & 15.2 & 34.3 & 30.5 \\
\hline \multicolumn{9}{|c|}{ Drainage area (square miles) } \\
\hline Less than 50 & 14 & 50.3 & 24.6 & 23.4 & 9.4 & 13.7 & 39.6 & 54.6 \\
\hline $50-149$ & 29 & 42.0 & 36.4 & 16.2 & 14.8 & 16.7 & 42.5 & 48.0 \\
\hline $150-300$ & 26 & 30.0 & 26.7 & 13.4 & 11.8 & 14.3 & 33.9 & 82.1 \\
\hline Greater than 300 & 33 & 26.9 & 23.6 & 15.7 & 9.2 & 15.8 & 27.8 & 40.6 \\
\hline
\end{tabular}

difference. As with streamgages with short periods of record, streamgages with small drainage areas can be affected by isolated weather events or unique hydrologic or geologic factors that may not translate well to other streamgages when using the drainage-area ratio method.

A Wilcoxon signed-rank test is a non-parametric test that is used to detect a significant difference between the two paired datasets (Helsel and Hirsch, 1992). A Wilcoxon signedrank test was conducted to compare the streamflow statistics computed using streamgage data and those transferred from the streamgages within the drainage-area ratio of 0.33-3.0. None of the paired datasets were found to be significantly different at the 95-percent confidence interval.

Transferred statistics were compared graphically to regression equation estimates for the same streamgage to evaluate how the drainage-area ratio method compares to the use of regression equations. Current regression equations were used in this comparison for estimating low-flow frequencies (Stuckey, 2006), peak-flow frequencies (Roland and Stuckey, 2008), and flow-duration exceedances (Stuckey and others, 2012). The absolute percent differences were plotted against the drainage-area ratio for estimates of streamflow determined from regression equations and the drainage-area ratio method. LOESS curves were applied to the datasets to indicate the range of ratios where drainage area method generally performs better than regression equations. The smoothed curves are shown in figure 12, the red line is drawn through the absolute

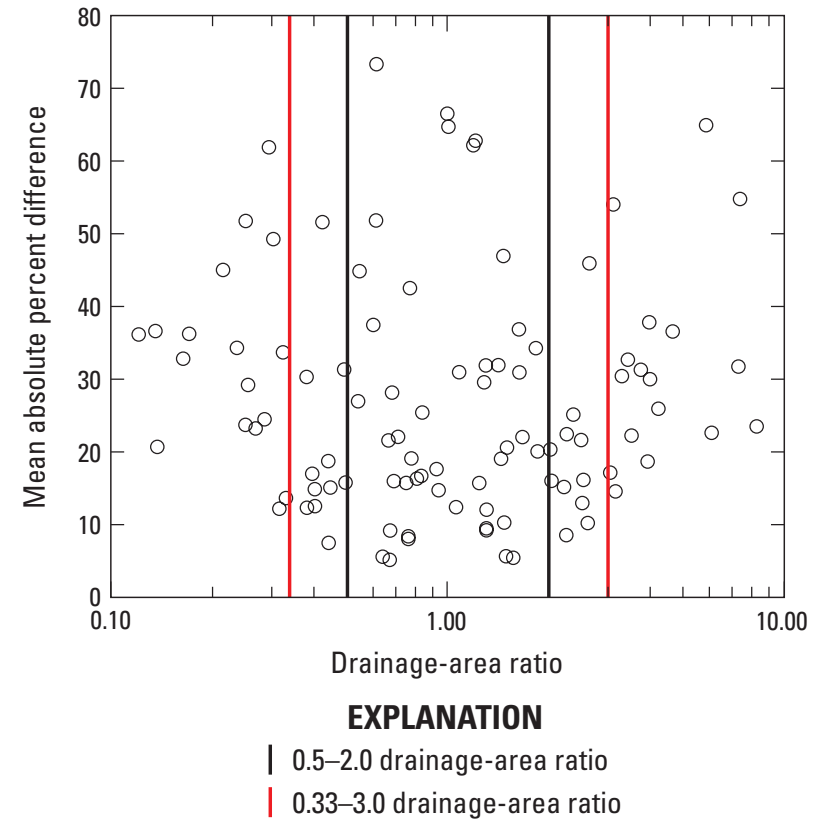

Figure 10. Absolute percent difference between observed and transferred streamflow statistics using the drainage-area ratio method in relation to drainage-area ratio at selected U.S. Geological Survey streamgages in Pennsylvania and New York. 
percent differences using the drainage-area ratio method, and the blue line is drawn through the absolute percent differences using regression equations. The points where the red line crosses the blue line indicate where the drainage-area ratio method performs better than regression equations. Individual plots for each of the statistics are in Appendix 4.

Using the mean absolute percent differences for all the streamflow statistics, the drainage-area ratio method generally performs better than regression equations for drainage-area ratios between approximately 0.45 and 3.2 (fig. 12). Although

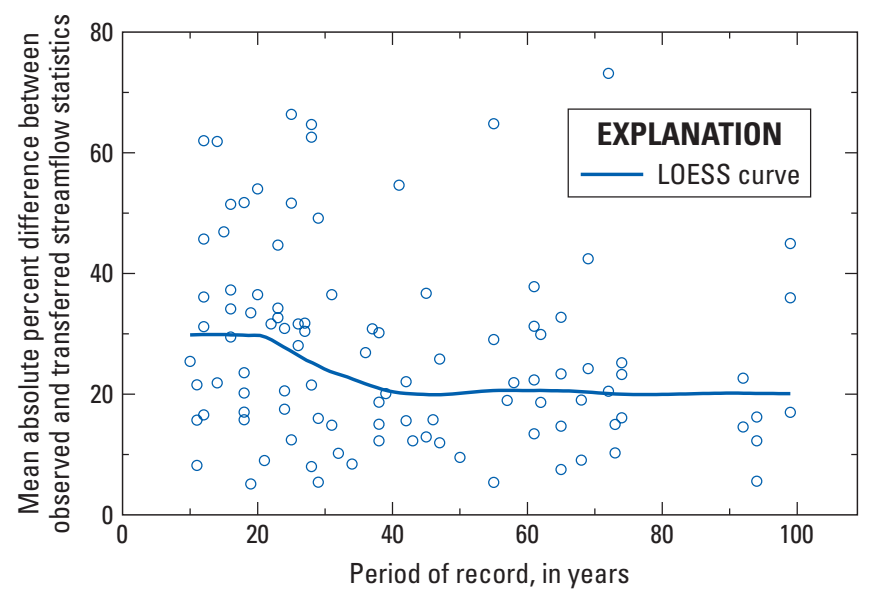

Figure 11. Relation between period of record and absolute percent differences for transferred streamflow statistics at selected U.S. Geological Survey streamgages in Pennsylvania and New York.

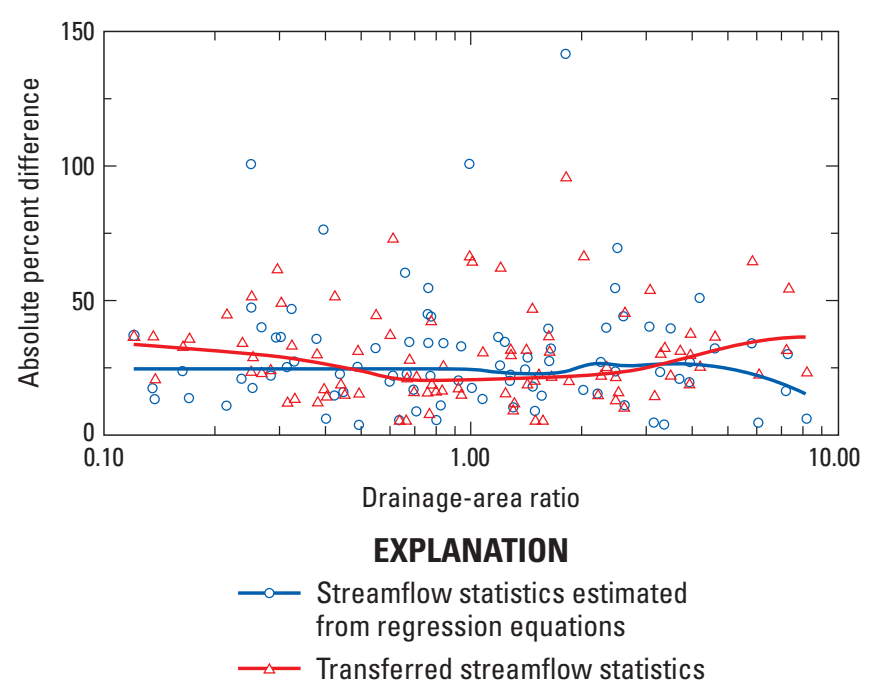

Figure 12. Example relation of drainage-area ratio to absolute percent difference for transferred streamflow statistics and streamflow statistics estimated from regression equations. the drainage-area ratio varied depending on the statistic transferred (Appendix 4), generally the low-flow statistics had a larger range of drainage-area ratios that performed better than regression equations than the higher flow statistics. The regression equations performed better than the drainage-area ratio method using all ratios for the Q100, P1, and P5, indicating that the regression equations developed for Pennsylvania may estimate high-flow statistics better than those from a nearby streamgage, regardless of the drainage-area ratio.

For the purposes of this study, the drainage-area ratios of $0.33-3.0$ were selected to be used for the identification of potential geographic gaps in the reference streamgage network. For real-world application of the drainage-area ratio method, this analysis indicates that other factors besides drainage area need to be evaluated before use. Other factors to consider are the period of record at the streamgages (40 years or more is preferable), whether or not the period of record contains unusually wet or dry periods, similarity of basin characteristics (particularly geology), and the type of streamflow statistic to be transferred (frequency or flow duration exceedance; low flow or high flow).

\section{Delineation of Gage Statistical Areas}

The National Hydrography Dataset Plus (NHD+) and the NHD+ Flow Table Navigator Tool (Horizon Systems, Inc., 2010) were used to identify NHD reaches along the stream network with a cumulative drainage area that corresponds to the drainage-area ratio of $0.33-3.0$, defined for this study as the GSA. The stream reach bounded by the most downstream and upstream points on the NHD reaches were considered to be statistically representative of the streamgage. This analysis was limited to basins with drainage areas between 15 and $500 \mathrm{mi}^{2}$. For drainage areas less than $15 \mathrm{mi}^{2}$, the GSA was considered to be the entire basin because of software limitations and use of a 1:100,000-scale stream dataset. The GSA of watersheds greater than $500 \mathrm{mi}^{2}$ encompassed very large and overlapping areas and was, therefore, excluded from the analysis.

The methodology to determine the GSA for a streamgage uses the watersheds created by the 0.33-3.0 drainage-area ratios in combination with the 1:100,000-scale NHD+ version 1 stream dataset, ArcMap version 9.3, and the NHD+ VAA COM Object Navigator Tool (Horizon Systems, Inc., 2014). The VAA COM Object Navigator Tool has the capability to perform upstream navigation from a starting point on a main stem stream and tributaries, as well as downstream navigation on a main stem stream and divergences. For consistency and broad application of determining the GSA, the VSR was identified as having the same stream name as the streamgage location. The VAA COM Object Navigator Tool was used to identify the same named stream along the VSR within the GSA as the reference streamgage. 
To verify that the stream name in NHD+ was the same as the streamgage name, the Identify Tool in ArcMap was used. In addition, the uniquely coded reach value was retrieved for the navigation process. A query was developed to extract the VSR for the named stream at the streamgage. On the basis of the stream name in the NHD+ fields, the VSR was selected by extending upstream from the streamgage to the stream segment containing one-third of the drainage area of the streamgage and extending downstream from the stream segment containing three times the drainage area of the streamgage. For many VSR determinations, the cumulative drainage area determined using this methodology did not exactly match the calculated $0.33-3.0$ drainage area because of the location of the watersheds intersecting the stream. The watersheds resulting in the cumulative area closest to the calculated 0.33-3.0 drainage area were used. The VSR resulting from the selection process was examined and checked for coding and network errors in the NHD+ stream network.

The GSA drainage network was selected using the VAA COM Object Navigator Tool. The downstream terminus of the VSR was used as the starting point to select the GSA drainage network with the VAA tool, and the network results were joined with the NHD+ catchment watersheds to create the 0.33-3.0 GSA. If a large tributary (greater than about $80 \mathrm{mi}^{2}$ ) enters at a confluence downstream from the streamgage, the entire area of the tributary was excluded from the GSA.

The process used to select the upstream streamgage drainage network is the same as described above, except the starting point is at the upstream terminus of the VSR. For consistency, the following procedure was used to determine the GSA watersheds for the geographic gap analysis. For application of the drainage-area ratio method to transfer streamflow statistics, additional analysis would need to be performed to determine the appropriateness of the reference streamgage in relation to the ungaged site.

1. Determine whether there are current continuous-record streamgages on any of the tributaries. If there are, the upstream GSA extent was stopped at the downstream GSA extent of tributary streamgage. If there are no streamgages, step 2 below was followed.

2. Using the Pennsylvania StreamStats program (Stuckey and Hoffman, 2010), basin characteristics and flow statistics from regression equations were determined for each of the large tributary watersheds and the main stem of the VSR at the streamgage. The basin characteristics, annual mean flow, and cubic feet per square mile (CFSM; equal to the mean annual discharge divided by the drainage area) were determined.

a. If the basin characteristics or CFSM were substantially different, the upstream GSA extent was stopped at confluence of major tributaries. b. If the basin characteristics or CFSM were not substantially different, the upstream GSA extent was extended on both major tributaries to the one-third drainage-area ratio cutoff.

c. The upstream GSA extent was stopped at the outflow of a large lake or reservoir. It was beyond the scope of the study to determine whether the large lakes and reservoirs were significantly controlling streamflow.

d. If there was a confluence of major tributaries, the GSA area included the tributary with the larger drainage area.

The result of this selection process is the GSA watershed, which is defined as the total extent of the drainage area for any point located on the VSR. Because the GSA is a watershed based on drainage catchments, there are stream segments within the defined GSA that are not applicable for the transfer of streamflow statistics from a nearby streamgage because the drainage areas for small tributaries are outside the appropriate drainage-area ratio. It was beyond the scope of this study to identify the VSRs within each GSA. The area outside the GSA is defined as the gage statistical gap. This area represents the drainage areas for points on the stream where the flow statistics are not transferrable and represents a geographic gap (fig. 9).

\section{Analysis of Geographic Gaps}

The process described in the previous section was applied to all reference streamgages in the study area of less than $500 \mathrm{mi}^{2}$. The GSA of watersheds greater than $500 \mathrm{mi}^{2}$ encompassed very large and overlapping areas, so those watersheds were excluded from the analysis. All HUC12 subwatersheds with 50 percent or greater of the area within a GSA were considered to be entirely within the GSA. It is important to note, however, that only those stream segments considered to be VSRs, as defined by drainage area, within the GSAs may be applicable for the transfer of streamflow statistics. All HUC12 subwatersheds not included in a streamgage GSA or that had less than 50 percent of the area within a GSA were considered potential geographic gaps in the streamgage network. Overall, 34 percent of the study area is represented by a reference streamgage. Within the major river basins, 38 percent of the Delaware River Basin, 33 percent of the Susquehanna and Potomac River Basins, and 34 percent of the Ohio and Saint Lawrence Basins are represented by a reference streamgage. There were 1,102 HUC12 subwatersheds of the 1,662 HUC12 subwatersheds in the study area outside the GSA (figs. 13-15). Some of these HUC12 subwatersheds may contain reference streamgages, but because the GSA of the streamgage was less than one-half the area of the HUC12 subwatershed, the HUC12 subwatershed was considered to be outside the GSA. 


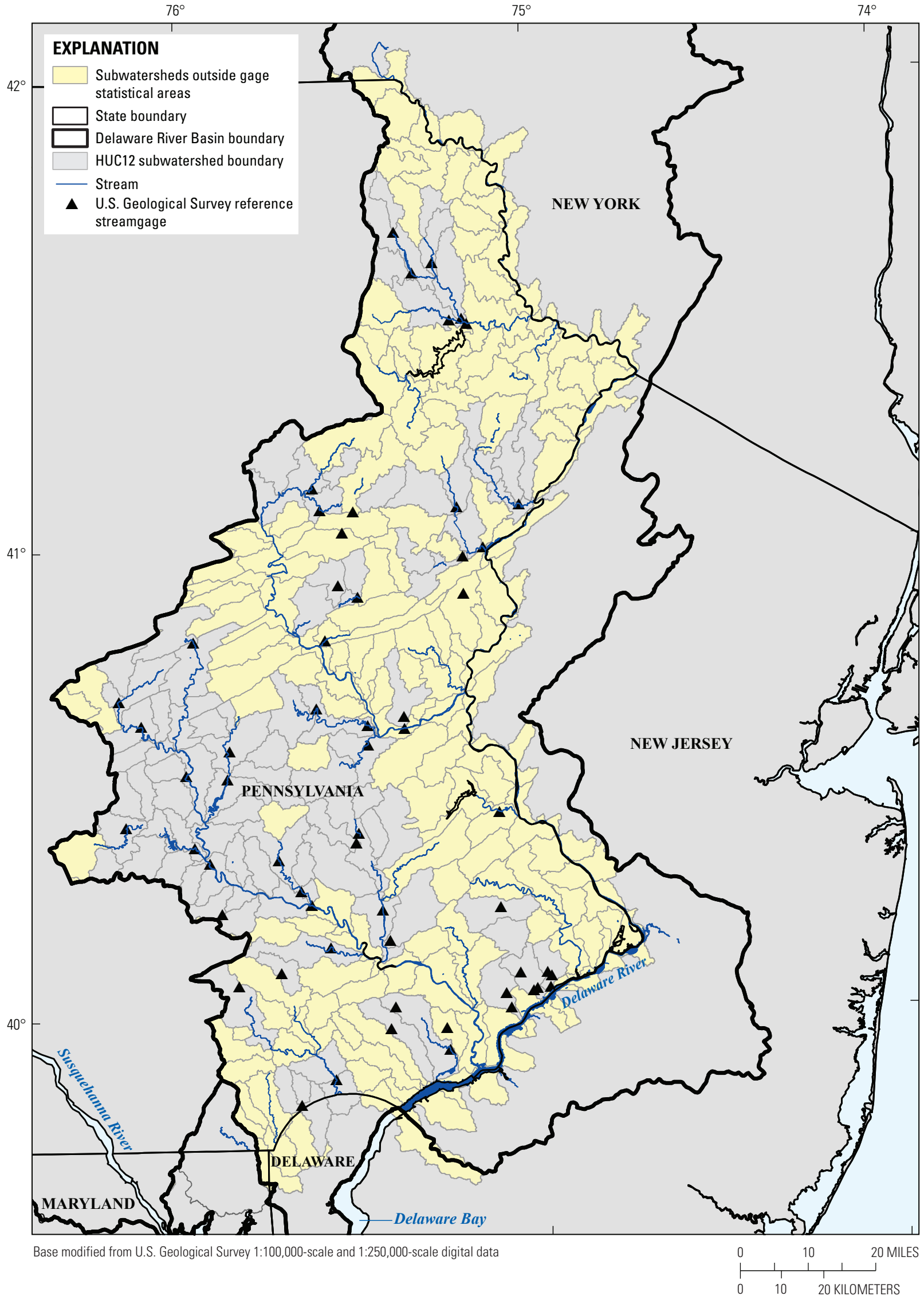

Figure 13. Location of 12-digit hydrologic unit code (HUC12) subwatersheds outside gage statistical areas in the Delaware River Basin. 


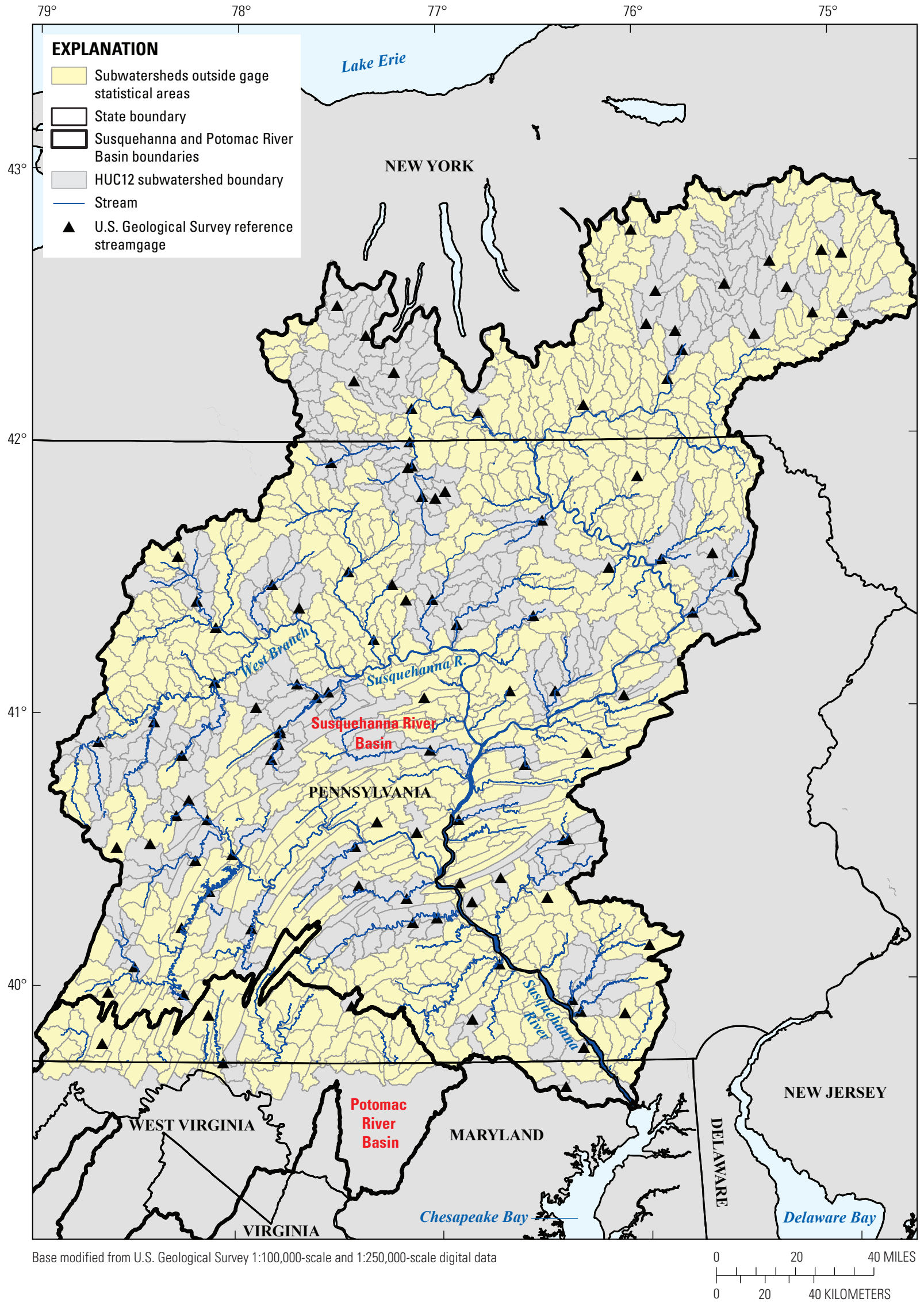

Figure 14. Location of 12-digit hydrologic unit code (HUC12) subwatersheds outside gage statistical areas in the Susquehanna and Potomac River Basins. 


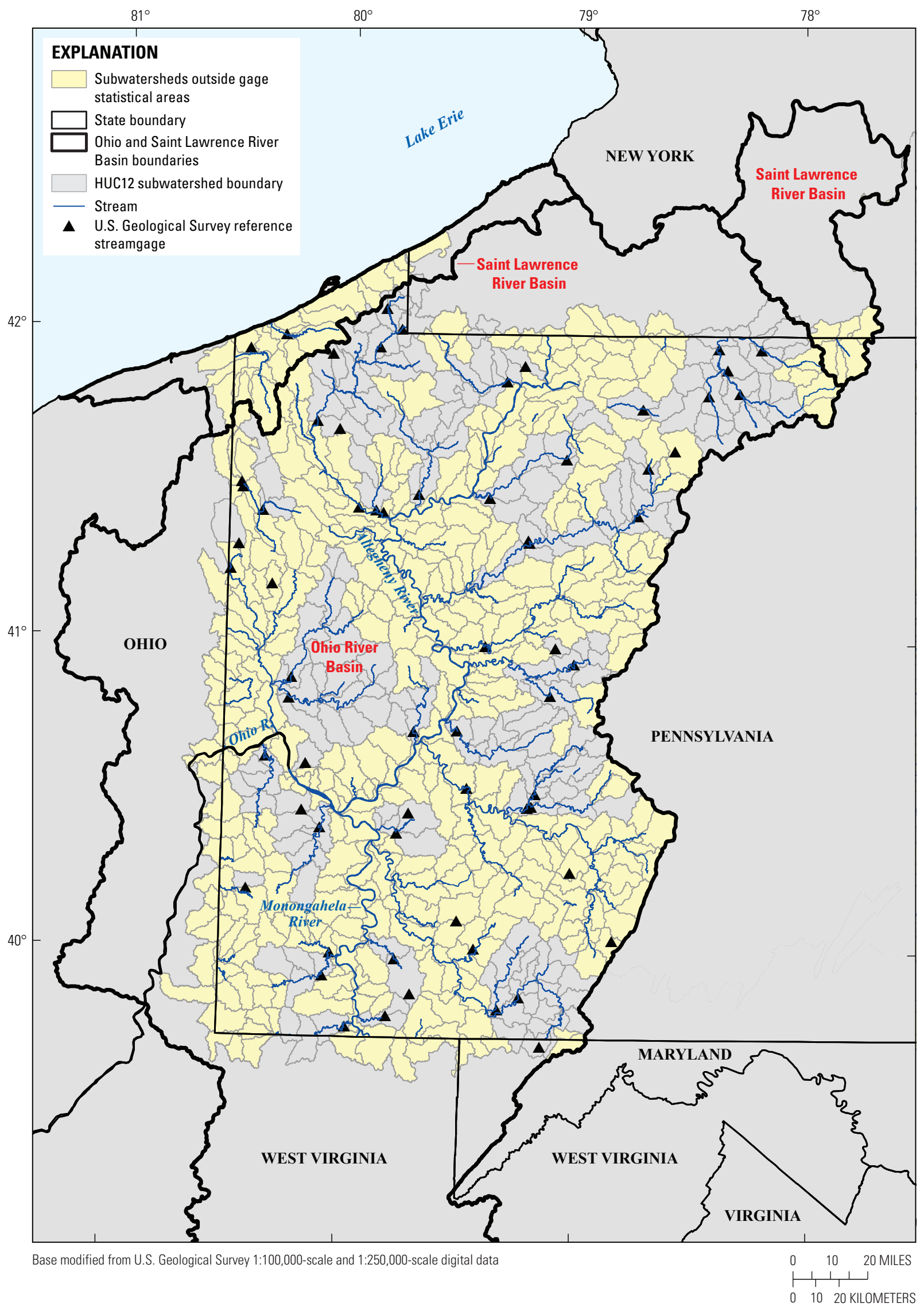

Figure 15. Location of 12-digit hydrologic unit code (HUC12) subwatersheds outside gage statistical areas in the Ohio and Saint Lawrence River Basins. 


\section{Estimated Streamflow Correlation of Ungaged Watersheds with Reference Streamgages}

The USGS Baseline Streamflow Estimator (BaSE) version 1.1 (Stuckey and others, 2012) was used to determine how well HUC12 subwatersheds in Pennsylvania are represented by the reference streamgage network, based on estimated streamflow correlation. This analysis was done only for Pennsylvania because a similar program was not available for New York at the time of analysis. The BaSE program uses a predetermined set of 168 reference streamgages in Pennsylvania, New York, Ohio, Maryland, and West Virginia, which are listed in Stuckey and others (2012, Appendix 1).

The BaSE program selects a reference streamgage for an ungaged site in Pennsylvania on the basis of geostatistical estimates of streamflow correlation. The BaSE program uses map correlation, an application of ordinary kriging, summarized here from Archfield and Vogel (2010). A spatial model, termed a "variogram," is fit to the correlation values between each streamgage and the other streamgages in the study area, resulting in one spatial model per streamgage. This spatial model is used to estimate the correlation between the streamgage and an ungaged site. When there is more than one potential reference streamgage, the spatial model can be used to discern which reference streamgage results in the highest estimated correlation with the ungaged site.

The centroid of each HUC12 subwatershed was determined using a GIS spatial analysis. The centroid location of each HUC12 subwatershed was entered as an ungaged site into the BaSE program to determine the reference streamgage with the highest estimated correlation with the HUC12 watershed. The BaSE program provided the name of the reference streamgage and the correlation coefficient for the five best estimated correlations.

Overall, the estimated correlation coefficients for the HUC12 subwatersheds in Pennsylvania were relatively high, ranging from 0.8896 to 0.9974 . The HUC12 subwatersheds were divided into three groups - those with the lowest estimated streamflow correlation (correlation coefficient less than or equal to 0.92 ), those with estimated streamflow correlation coefficients greater than 0.92 and less than 0.96 , and those with the highest estimated streamflow correlation (correlation coefficient equal to or greater than 0.96). There were 249 HUC12 subwatersheds in the lowest estimated correlation group, 680 watersheds in the middle estimated correlation group, and 518 watersheds in the highest estimated correlation group. The locations of the HUC12 subwatersheds with an estimated correlation less than 0.96 are shown in figures 16-18. In all the major basins, groupings of HUC12 subwatersheds with estimated streamflow correlation less than 0.96 are adjacent to major rivers. This is likely because streamgages with drainage area greater than $1,400 \mathrm{mi}^{2}$ were not used to create the correlation maps in BaSE. Because these streamgages with large drainage areas were excluded from the map correlation process, there were no correlations for the vicinity of the streamgage, resulting in lowered estimated correlation.

HUC12 subwatersheds with estimated streamflow correlations less than 0.96 are scattered throughout the basins in headwater watersheds.

\section{Reference Streamgage Network Gaps}

The results from the basin characteristic, geographic, and estimated streamflow correlation analyses presented above were combined to identify HUC12 subwatersheds in Pennsylvania and the Susquehanna River Basin in Pennsylvania and New York that lack a representative reference streamgage. Overall, 1,405, or about 84 percent, of the 1,662 HUC12 subwatersheds had at least one basin characteristic, geographic, or correlation gap. A total of 668, or 40 percent, of the 1,662 HUC12 subwatersheds had two gaps, and 139 , or about 8 percent, of HUC12 subwatersheds had gaps identified by all three analyses (table 5 and Appendix 5). Of the 668 HUC12 subwatersheds exhibiting 2 gaps, 11 are in New York where the analyses were limited to 2; the streamflow correlation analysis was excluded. Those HUC12 subwatersheds in Pennsylvania exhibiting all 3 gaps or 2 gaps for those HUC12 subwatersheds in New York are shown in table 6 and summarized by 8-digit HUC (HUC8) in table 7. The Beaver HUC8 watershed (05030104) has the highest percentage of gaps at 67 percent (table 7). The locations of HUC12 subwatersheds with resulting gaps are shown in figures 19-21.

The Pennsylvania locations of HUC12 subwatersheds with three gaps and HUC12 subwatersheds in the Susquehanna Basin in New York with two gaps are shown in figure 22. Ideally, these watersheds have the highest priority when siting a new streamgage. Although not used in the analysis, current (2015) streamgages with less than 10 years of record are shown on figure 22. Given sufficient period of record, these streamgages could potentially become reference streamgages. One such streamgage is contained within a HUC12 subwatershed with three gaps in the Ohio River Basin. The Potomac River Basin, which historically has had few reference streamgages, had the highest percentage of HUC12 subwatersheds (15 percent) with three gaps (table 5). HUC12 subwatersheds with three gaps are also found in the southwestern corner of Pennsylvania (fig. 22), another area of Pennsylvania that historically has been lacking in reference streamgages. Overall, the Ohio River Basin had the lowest percentage of watersheds ( 8 percent) with three gaps (table 5).

\section{Streamgages with High Substitution Potential in the Current Network}

Streamgages in areas with similar hydrologic characteristics and in close proximity to one another can potentially provide similar information, termed here "streamgages with high substitution potential." Current (2015) streamgages with high substitution potential, regardless of their use as a reference streamgage, were identified using the following method. Streamgages were considered for substitution if (1) the streamflow correlation coefficient was equal to or greater 


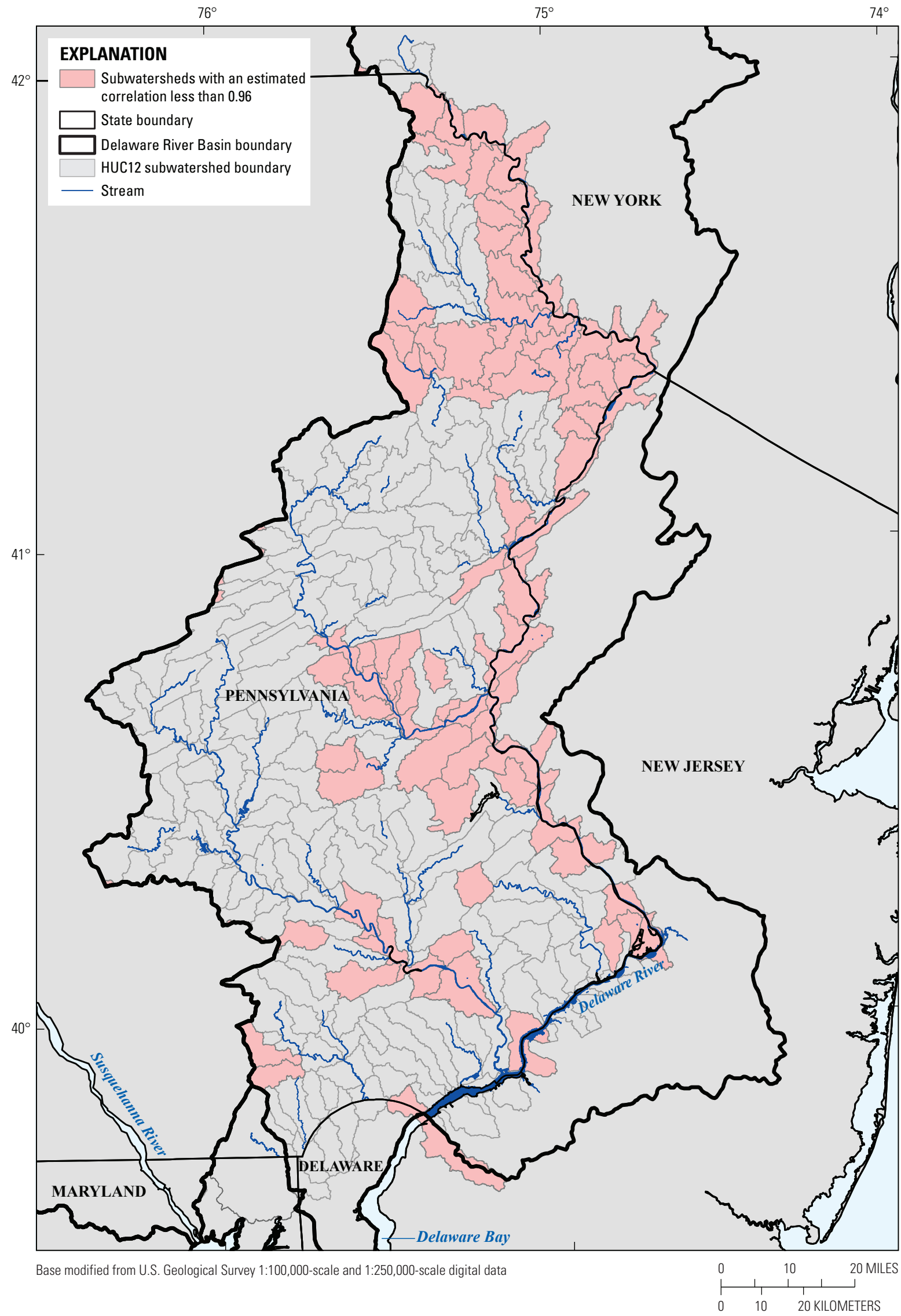

Figure 16. Location of a 12-digit hydrologic unit code (HUC12) subwatershed with an estimated streamflow correlation less than 0.96 in the Delaware River Basin. 


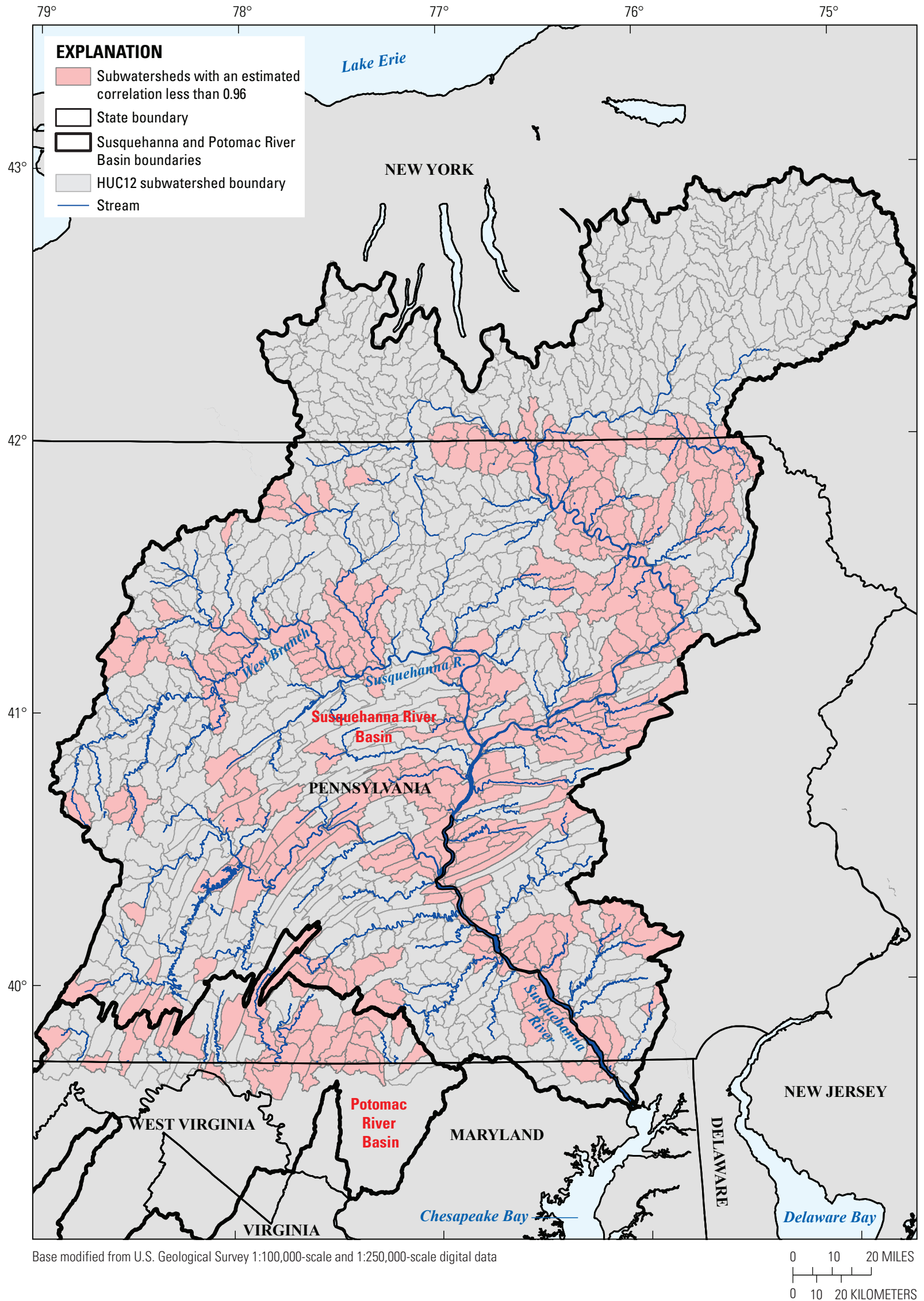

Figure 17. Location of a 12-digit hydrologic unit code (HUC12) subwatershed with an estimated streamflow correlation less than 0.96 in the Susquehanna River Basin. 


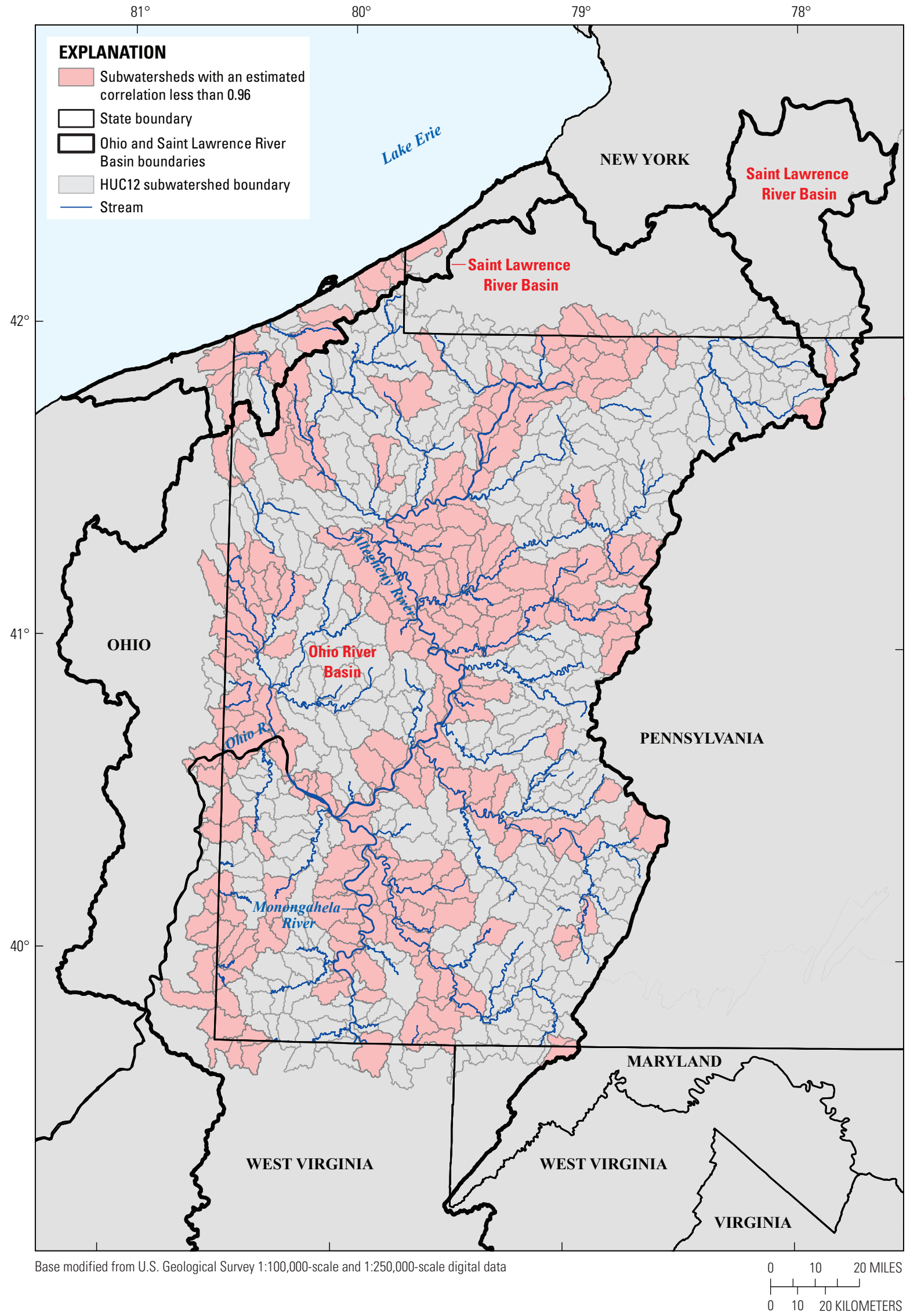

Figure 18. Location of a 12-digit hydrologic unit code (HUC12) subwatershed with an estimated streamflow correlation less than 0.96 in the Ohio River Basin. 
Table 5. Summary of basin characteristic, geographic, and correlation gaps, by basin, in Pennsylvania and New York.

[HUC12, 12-digit hydrologic unit code; --, no data]

\begin{tabular}{|c|c|c|c|c|c|c|c|}
\hline Basin & $\begin{array}{c}\text { Total number } \\
\text { of HUC12 } \\
\text { subwater- } \\
\text { sheds }\end{array}$ & $\begin{array}{c}\text { Basin } \\
\text { characteristic } \\
\text { gap }\end{array}$ & $\begin{array}{c}\text { Geographic } \\
\text { gap }\end{array}$ & $\begin{array}{c}\text { Estimated } \\
\text { correlation } \\
\text { gap }\end{array}$ & $\begin{array}{c}\text { HUC12 } \\
\text { subwater- } \\
\text { sheds } \\
\text { with } \\
1 \text { gap }\end{array}$ & $\begin{array}{c}\text { HUC12 } \\
\text { subwater- } \\
\text { sheds } \\
\text { with } \\
2 \text { gaps }\end{array}$ & $\begin{array}{c}\text { HUC12 } \\
\text { subwater- } \\
\text { sheds } \\
\text { with } \\
3 \text { gaps }\end{array}$ \\
\hline Delaware River Basin & 229 & 48 & 141 & 142 & 75 & 95 & 22 \\
\hline Susquehanna River Basin & 645 & 157 & 430 & 433 & 209 & 305 & 67 \\
\hline Potomac River Basin & 65 & 19 & 62 & 43 & 16 & 39 & 10 \\
\hline Ohio River Basin & 483 & 60 & 313 & 299 & 153 & 204 & 37 \\
\hline Saint Lawrence River Basin & 25 & 8 & 25 & 12 & 8 & 14 & 3 \\
\hline Study area total & 1,662 & 320 & 1,102 & 929 & 598 & 668 & 139 \\
\hline
\end{tabular}

than $0.96,(2)$ the streamgages have 10 years of concurrent record, and (3) the streamgages are located in the same watershed within the GSA of the streamgage. A correlation matrix was generated using concurrent daily streamflow data from current continuous record streamgages with greater than 10 years of record. Correlations were based on log-transformed daily streamflow values. Streamgages with a Pearson product-moment correlation coefficient (Pearson, 1896) equal to or greater than 0.96 were considered. On that group of streamgages, a spatial analysis was conducted to identify the streamgages with high streamflow correlation (equal to or greater than 0.96 ) located in the same watershed and having a drainage-area ratio within the range of 0.33-3.0. Seventyfour streamgages with high substitution potential with at least one other streamgage were identified (table 8). The maximum number of streamgages found to have high substitution potential with a single streamgage is three. These streamgages are listed with more detail in Appendix 6, including the distance between streamgages, drainage-area ratio, and streamflow correlation with the high substitution streamgages.

Although there are many uses of streamgage data, six primary uses that are important to a range of stakeholders and cooperators are shown in table 8 . The selected primary uses identified in table 8 are (1) Regulatory/Compliance, as determined from information obtained from PaDEP, SRBC, and Delaware River Basin Commission (2) flood forecast, as determined from information obtained from the National Weather Service; (3) drought monitor, as determined from information obtained from PaDEP; (4) State water-quality network, as determined from information obtained from PaDEP; (5) Reservoir/Lock and Dam operation, as determined from proximity to U.S. Army Corps of Engineers projects; and (6) National Streamflow Information Program (NSIP), as determined from information from the USGS. Many of the streamgages with high substitution potential have specific regulatory and (or) compliance uses for which streamflow data are required to satisfy regulatory, permitting, or pass-by flow requirements. Information on regulatory or compliance uses for streamgages in the Ohio River Basin (streamgage numbers beginning with " 03 " in table 8 ) was not readily available and was not included in this analysis. Many of the streamgages on larger streams with high substitution potential are needed for reservoir operations and, in the Ohio Basin, for lock and dam operation. The NSIP program identifies streamgages meeting five Federal goals (interstate and international waters, forecasts, major river outflows, sentinel watersheds, and water quality) (U.S. Geological Survey, 2014g).

Of the 74 streamgages with high substitution potential, 46 have 3 or more selected primary uses, 16 have 2 selected primary uses, 8 have 1 selected primary uses, and 4 have no selected primary use. Of the 8 streamgages with one selected primary use, 6 are used in flood forecasting by the National Weather Service and 2 are used in the State water quality network. Of the four that do not have any selected primary uses, the data provided by these streamgages are likely important to the individual cooperators funding the streamgage.

The streamgages listed in table 8 are highly related to another streamgage and could possibly be used in place of the other. Many of the streamgages listed in table 8 have more than one other streamgage with high substitution potential (example, Swatara Creek at Inwood has a high substitution potential with three other streamgages on the Swatara Creek). Most of the streamgages have specific uses important to a stakeholder and may have been written into specific policy or requirements associated with permits, reservoir operation manuals, forecast models, or other management plans. In these situations, it may be difficult to substitute a streamgage without a lengthy process to alter the policy or requirements currently in place. In other situations, such substitutions may be more feasible, and funding for a streamgage with high substitution potential may be re-allocated to initiate a needed streamgage to fill an identified gap in the network. 
Table 6. 12-digit hydrologic unit code (HUC12) subwatersheds with basin characteristic, geographic, and correlation gaps in Pennsylvania and New York.

[HUC12; 12-digit hydrologic unit code; DEL, Delaware River Basin; STLAW, Saint Lawrence River Basin; OHIO, Ohio River Basin; POT, Potomac River Basin; SUSQ, Susquehanna River Basin; SUSQ NY, Susquehanna River Basin watersheds entirely in New York; X indicates gap; ---, streamflow correlation gap analysis not available]

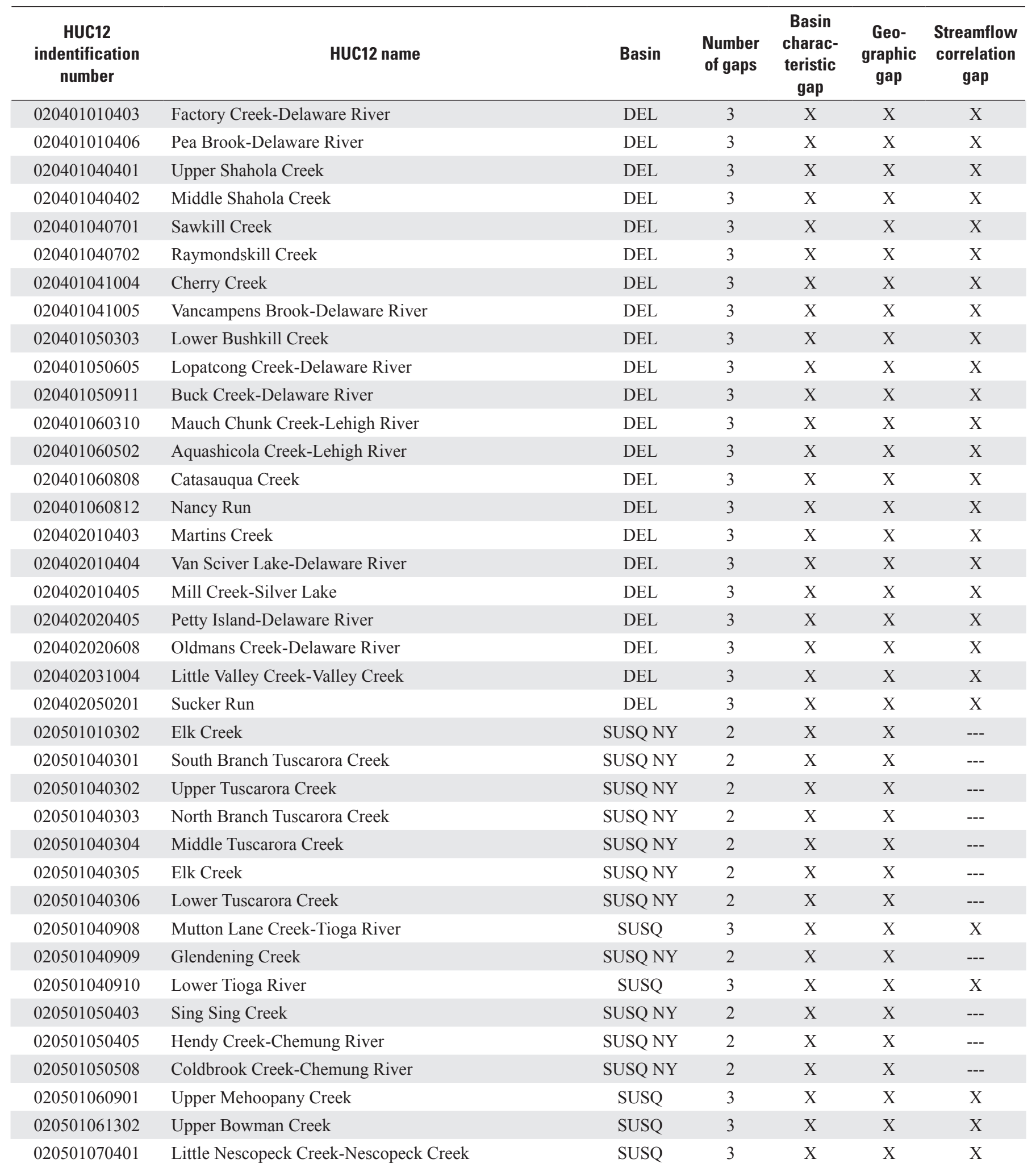


Table 6. 12-digit hydrologic unit code (HUC12) subwatersheds with basin characteristic, geographic, and correlation gaps in Pennsylvania and New York.-Continued

[HUC12; 12-digit hydrologic unit code; DEL, Delaware River Basin; STLAW, Saint Lawrence River Basin; OHIO, Ohio River Basin; POT, Potomac River Basin; SUSQ, Susquehanna River Basin; SUSQ NY, Susquehanna River Basin watersheds entirely in New York; X indicates gap; ---, streamflow correlation gap analysis not available]

\begin{tabular}{|c|c|c|c|c|c|c|}
\hline $\begin{array}{c}\text { HUC12 } \\
\text { indentification } \\
\text { number }\end{array}$ & HUC12 name & Basin & $\begin{array}{l}\text { Number } \\
\text { of gaps }\end{array}$ & $\begin{array}{c}\text { Basin } \\
\text { charac- } \\
\text { teristic } \\
\text { gap }\end{array}$ & $\begin{array}{c}\text { Geo- } \\
\text { graphic } \\
\text { gap }\end{array}$ & $\begin{array}{c}\text { Streamflow } \\
\text { correlation } \\
\text { gap }\end{array}$ \\
\hline 020501070701 & East Branch Fishing Creek & SUSQ & 3 & $\mathrm{X}$ & $\mathrm{X}$ & $\mathrm{X}$ \\
\hline 020502010702 & Trout Run & SUSQ & 3 & $\mathrm{X}$ & $\mathrm{X}$ & $\mathrm{X}$ \\
\hline 020502010710 & Sterling Run & SUSQ & 3 & $\mathrm{X}$ & $\mathrm{X}$ & $\mathrm{X}$ \\
\hline 020502010711 & Birch Island Run & SUSQ & 3 & $\mathrm{X}$ & $\mathrm{X}$ & $\mathrm{X}$ \\
\hline 020502010712 & Lower Three Runs-West Branch Susquehanna River & SUSQ & 3 & $\mathrm{X}$ & $\mathrm{x}$ & $\mathrm{X}$ \\
\hline 020502010713 & Burns Run-West Branch Susquehanna River & SUSQ & 3 & $\mathrm{X}$ & $\mathrm{X}$ & $\mathrm{X}$ \\
\hline 020502020202 & Clear Creek & SUSQ & 3 & $\mathrm{X}$ & $\mathrm{X}$ & $\mathrm{X}$ \\
\hline 020502020303 & Laurel Run & SUSQ & 3 & $\mathrm{X}$ & $\mathrm{X}$ & $\mathrm{X}$ \\
\hline 020502020304 & Medix Run & SUSQ & 3 & $\mathrm{x}$ & $\mathrm{X}$ & $\mathrm{X}$ \\
\hline 020502020308 & Dents Run & SUSQ & 3 & $\mathrm{X}$ & $\mathrm{X}$ & $\mathrm{X}$ \\
\hline 020502020403 & Upper First Fork Sinnemahoning Creek & SUSQ & 3 & $\mathrm{X}$ & $\mathrm{x}$ & $\mathrm{X}$ \\
\hline 020502020404 & Freeman Run & SUSQ & 3 & $\mathrm{X}$ & $\mathrm{X}$ & $\mathrm{X}$ \\
\hline 020502020502 & Sinnemahoning Creek-West Branch Susquehanna River & SUSQ & 3 & $\mathrm{x}$ & $\mathrm{X}$ & $\mathrm{X}$ \\
\hline 020502030201 & Cooks Run & SUSQ & 3 & $\mathrm{x}$ & $\mathrm{X}$ & $\mathrm{X}$ \\
\hline 020502030203 & Drury Run & SUSQ & 3 & $\mathrm{X}$ & $\mathrm{x}$ & $\mathrm{X}$ \\
\hline 020502030205 & Hall Run-West Branch Susquehanna River & SUSQ & 3 & $\mathrm{X}$ & $\mathrm{X}$ & $\mathrm{X}$ \\
\hline 020502030402 & Rattlesnake Run-West Branch Susquehanna River & SUSQ & 3 & $\mathrm{X}$ & $\mathrm{X}$ & $\mathrm{X}$ \\
\hline 020502030403 & Clendenin Branch Baker Run & SUSQ & 3 & $\mathrm{x}$ & $\mathrm{X}$ & $\mathrm{X}$ \\
\hline 020502030404 & Baker Run & SUSQ & 3 & $\mathrm{X}$ & $\mathrm{X}$ & $\mathrm{X}$ \\
\hline 020502030405 & North Fork Tangascootack Creek & SUSQ & 3 & $\mathrm{X}$ & $\mathrm{X}$ & $\mathrm{X}$ \\
\hline 020502030406 & Tangascootack Creek & SUSQ & 3 & $\mathrm{X}$ & $\mathrm{X}$ & $\mathrm{X}$ \\
\hline 020502030407 & Lick Run & SUSQ & 3 & $\mathrm{x}$ & $\mathrm{X}$ & $\mathrm{X}$ \\
\hline 020502030409 & Queens Run & SUSQ & 3 & $\mathrm{x}$ & $\mathrm{X}$ & $\mathrm{X}$ \\
\hline 020502030410 & McElhattan Creek & SUSQ & 3 & $\mathrm{X}$ & $\mathrm{X}$ & $\mathrm{X}$ \\
\hline 020502050201 & Ninemile Run & SUSQ & 3 & $\mathrm{x}$ & $\mathrm{x}$ & $\mathrm{X}$ \\
\hline 020502050505 & Otter Run & SUSQ & 3 & $\mathrm{X}$ & $\mathrm{X}$ & $\mathrm{X}$ \\
\hline 020502050604 & Mill Run-Pine Creek & SUSQ & 3 & $\mathrm{X}$ & $\mathrm{X}$ & $\mathrm{X}$ \\
\hline 020502050605 & Trout Run & SUSQ & 3 & $\mathrm{X}$ & $\mathrm{X}$ & $\mathrm{X}$ \\
\hline 020502050606 & Upper Pine Bottom Run-Pine Creek & SUSQ & 3 & $\mathrm{x}$ & $\mathrm{X}$ & $\mathrm{X}$ \\
\hline 020502061204 & Limestone Run-Northumberland County & SUSQ & 3 & $\mathrm{X}$ & $\mathrm{X}$ & $\mathrm{X}$ \\
\hline 020502061206 & Limestone Run-Union County & SUSQ & 3 & $\mathrm{X}$ & $\mathrm{X}$ & $\mathrm{X}$ \\
\hline 020503010902 & Rattling Creek & SUSQ & 3 & $\mathrm{X}$ & $\mathrm{X}$ & $\mathrm{X}$ \\
\hline 020503011002 & Fidlers Run-Susquehanna River & SUSQ & 3 & $\mathrm{X}$ & $\mathrm{X}$ & $\mathrm{X}$ \\
\hline 020503040102 & Mill Creek & SUSQ & 3 & $\mathrm{X}$ & $\mathrm{X}$ & $\mathrm{X}$ \\
\hline 020503040302 & Blacklog Creek & SUSQ & 3 & $\mathrm{x}$ & $\mathrm{X}$ & $\mathrm{X}$ \\
\hline 020503050201 & Rowe Run & SUSQ & 3 & $\mathrm{X}$ & $\mathrm{X}$ & $\mathrm{X}$ \\
\hline 020503050904 & Spring Creek & SUSQ & 3 & $\mathrm{X}$ & $\mathrm{X}$ & $\mathrm{X}$ \\
\hline 020503050906 & Swatara Creek-Susquehanna River & SUSQ & 3 & $\mathrm{X}$ & $\mathrm{X}$ & $\mathrm{X}$ \\
\hline
\end{tabular}


Table 6. 12-digit hydrologic unit code (HUC12) subwatersheds with basin characteristic, geographic, and correlation gaps in Pennsylvania and New York.-Continued

[HUC12; 12-digit hydrologic unit code; DEL, Delaware River Basin; STLAW, Saint Lawrence River Basin; OHIO, Ohio River Basin; POT, Potomac River Basin; SUSQ, Susquehanna River Basin; SUSQ NY, Susquehanna River Basin watersheds entirely in New York; X indicates gap; ---, streamflow correlation gap analysis not available]

\begin{tabular}{|c|c|c|c|c|c|c|}
\hline $\begin{array}{c}\text { HUC12 } \\
\text { indentification } \\
\text { number }\end{array}$ & HUC12 name & Basin & $\begin{array}{l}\text { Number } \\
\text { of gaps }\end{array}$ & $\begin{array}{l}\text { Basin } \\
\text { charac- } \\
\text { teristic } \\
\text { gap }\end{array}$ & $\begin{array}{l}\text { Geo- } \\
\text { graphic } \\
\text { gap }\end{array}$ & $\begin{array}{c}\text { Streamflow } \\
\text { correlation } \\
\text { gap }\end{array}$ \\
\hline 020503051002 & Clark Creek & SUSQ & 3 & $\mathrm{X}$ & $\mathrm{X}$ & $\mathrm{X}$ \\
\hline 020503051006 & Cove Creek-Susquehanna River & SUSQ & 3 & $\mathrm{X}$ & $\mathrm{X}$ & $\mathrm{X}$ \\
\hline 020503051008 & Spring Creek & SUSQ & 3 & $\mathrm{X}$ & $\mathrm{X}$ & $\mathrm{X}$ \\
\hline 020503051011 & Laurel Run-Susquehanna River & SUSQ & 3 & $\mathrm{X}$ & $\mathrm{X}$ & $\mathrm{X}$ \\
\hline 020503060102 & Plum Creek-South Branch Conewago Creek & SUSQ & 3 & $\mathrm{X}$ & $\mathrm{X}$ & $\mathrm{X}$ \\
\hline 020503060203 & Swift Run-Conewago Creek & SUSQ & 3 & $\mathrm{X}$ & $\mathrm{X}$ & $\mathrm{X}$ \\
\hline 020503060402 & Lower Little Conewago Creek & SUSQ & 3 & $\mathrm{X}$ & $\mathrm{X}$ & $\mathrm{x}$ \\
\hline 020503060502 & Davidsburg Run-Conewago Creek & SUSQ & 3 & $\mathrm{X}$ & $\mathrm{X}$ & $\mathrm{X}$ \\
\hline 020503060705 & Willis Run-Codorus Creek & SUSQ & 3 & $\mathrm{X}$ & $\mathrm{X}$ & $\mathrm{X}$ \\
\hline 020503060802 & Little Chickies Creek & SUSQ & 3 & $\mathrm{X}$ & $\mathrm{X}$ & $\mathrm{X}$ \\
\hline 020503060803 & Donegal Creek & SUSQ & 3 & $\mathrm{X}$ & $\mathrm{X}$ & $\mathrm{X}$ \\
\hline 020503060804 & Lower Chickies Creek & SUSQ & 3 & $\mathrm{X}$ & $\mathrm{X}$ & $\mathrm{X}$ \\
\hline 020503060904 & Cocalico Creek-Conestoga River & SUSQ & 3 & $\mathrm{X}$ & $\mathrm{X}$ & $\mathrm{X}$ \\
\hline 020503061104 & Middle Conestoga River & SUSQ & 3 & $\mathrm{X}$ & $\mathrm{X}$ & $\mathrm{X}$ \\
\hline 020503061502 & Tweed Creek-Octoraro Creek & SUSQ & 3 & $\mathrm{X}$ & $\mathrm{X}$ & $\mathrm{X}$ \\
\hline 020503061503 & Basin Run-Octoraro Creek & SUSQ & 3 & $\mathrm{X}$ & $\mathrm{X}$ & $\mathrm{X}$ \\
\hline 020503061701 & Conoy Creek & SUSQ & 3 & $\mathrm{X}$ & $\mathrm{X}$ & $\mathrm{x}$ \\
\hline 020503061702 & Hartman Run-Susquehanna River & SUSQ & 3 & $\mathrm{X}$ & $\mathrm{X}$ & $\mathrm{X}$ \\
\hline 020503061704 & Cabin Creek-Susquehanna River & SUSQ & 3 & $\mathrm{X}$ & $\mathrm{X}$ & $\mathrm{X}$ \\
\hline 020503061706 & Green Branch-Susquehanna River & SUSQ & 3 & $\mathrm{X}$ & $\mathrm{X}$ & $\mathrm{X}$ \\
\hline 020503061709 & Fishing Creek-Susquehanna River & SUSQ & 3 & $\mathrm{X}$ & $\mathrm{X}$ & $\mathrm{X}$ \\
\hline 020503061710 & Broad Creek & SUSQ & 3 & $\mathrm{X}$ & $\mathrm{X}$ & $\mathrm{X}$ \\
\hline 020503061711 & Conowingo Creek & SUSQ & 3 & $\mathrm{X}$ & $\mathrm{X}$ & $\mathrm{X}$ \\
\hline 020503061712 & Conowingo Dam-Susquehanna River & SUSQ & 3 & $\mathrm{X}$ & $\mathrm{X}$ & $\mathrm{X}$ \\
\hline 020600020102 & North East Creek & POT & 3 & $\mathrm{X}$ & $\mathrm{X}$ & $\mathrm{X}$ \\
\hline 020700020501 & Brush Creek & POT & 3 & $\mathrm{X}$ & $\mathrm{X}$ & $\mathrm{X}$ \\
\hline 020700020502 & Laurel Run & POT & 3 & $\mathrm{X}$ & $\mathrm{X}$ & $\mathrm{X}$ \\
\hline 020700030401 & East Branch Sideling Hill Creek & POT & 3 & $\mathrm{X}$ & $\mathrm{X}$ & $\mathrm{X}$ \\
\hline 020700030402 & West Branch Sideling Hill Creek & POT & 3 & $\mathrm{X}$ & $\mathrm{X}$ & $\mathrm{X}$ \\
\hline 020700040504 & Ditch Run-Potomac River & POT & 3 & $\mathrm{X}$ & $\mathrm{X}$ & $\mathrm{X}$ \\
\hline 020700040804 & Muddy Run & POT & 3 & $\mathrm{X}$ & $\mathrm{X}$ & $\mathrm{X}$ \\
\hline 020700041005 & West Branch Marsh Run-Marsh Run & POT & 3 & $\mathrm{X}$ & $\mathrm{X}$ & $\mathrm{X}$ \\
\hline 020700041006 & Middle Antietam Creek & POT & 3 & $\mathrm{X}$ & $\mathrm{X}$ & $\mathrm{X}$ \\
\hline 020700090501 & Alloway Creek & POT & 3 & $\mathrm{X}$ & $\mathrm{X}$ & $\mathrm{X}$ \\
\hline 041100030103 & Upper Ashtabula River & STLAW & 3 & $\mathrm{X}$ & $\mathrm{X}$ & $\mathrm{X}$ \\
\hline 041201010404 & Twelvemile Creek-Frontal Lake Erie & STLAW & 3 & $\mathrm{X}$ & $\mathrm{X}$ & $\mathrm{X}$ \\
\hline 041201010702 & Turkey Creek-Frontal Lake Erie & STLAW & 3 & $\mathrm{X}$ & $\mathrm{X}$ & $\mathrm{X}$ \\
\hline
\end{tabular}


Table 6. 12-digit hydrologic unit code (HUC12) subwatersheds with basin characteristic, geographic, and correlation gaps in Pennsylvania and New York.-Continued

[HUC12; 12-digit hydrologic unit code; DEL, Delaware River Basin; STLAW, Saint Lawrence River Basin; OHIO, Ohio River Basin; POT, Potomac River Basin; SUSQ, Susquehanna River Basin; SUSQ NY, Susquehanna River Basin watersheds entirely in New York; X indicates gap; ---, streamflow correlation gap analysis not available]

\begin{tabular}{|c|c|c|c|c|c|c|}
\hline $\begin{array}{c}\text { HUC12 } \\
\text { indentification } \\
\text { number }\end{array}$ & HUC12 name & Basin & $\begin{array}{l}\text { Number } \\
\text { of gaps }\end{array}$ & $\begin{array}{c}\text { Basin } \\
\text { charac- } \\
\text { teristic } \\
\text { gap }\end{array}$ & $\begin{array}{c}\text { Geo- } \\
\text { graphic } \\
\text { gap }\end{array}$ & $\begin{array}{c}\text { Streamflow } \\
\text { correlation } \\
\text { gap }\end{array}$ \\
\hline 050100011205 & Cornplanter Run-Allegheny River & OHIO & 3 & $\mathrm{X}$ & $\mathrm{X}$ & $\mathrm{X}$ \\
\hline 050100011208 & Hodge Run-Allegheny River & OHIO & 3 & $\mathrm{X}$ & $\mathrm{x}$ & $\mathrm{X}$ \\
\hline 050100030104 & East Hickory Creek & OHIO & 3 & $\mathrm{X}$ & $\mathrm{X}$ & $\mathrm{X}$ \\
\hline 050100061101 & Sugar Creek & OHIO & 3 & $\mathrm{X}$ & $\mathrm{x}$ & $\mathrm{x}$ \\
\hline 050100061103 & South Fork Pine Creek & OHIO & 3 & $\mathrm{X}$ & $\mathrm{x}$ & $\mathrm{x}$ \\
\hline 050100080101 & Headwaters Loyalhanna Creek & OHIO & 3 & $\mathrm{X}$ & $\mathrm{X}$ & $\mathrm{X}$ \\
\hline 050100080201 & Blacklegs Creek & OHIO & 3 & $\mathrm{X}$ & $\mathrm{X}$ & $\mathrm{X}$ \\
\hline 050100090308 & Allegheny River-Ohio River & OHIO & 3 & $\mathrm{X}$ & $\mathrm{x}$ & $\mathrm{X}$ \\
\hline 050200040602 & Upper Big Sandy Creek & OHIO & 3 & $\mathrm{X}$ & $\mathrm{x}$ & $\mathrm{x}$ \\
\hline 050200050102 & West Virginia Fork & OHIO & 3 & $\mathrm{X}$ & $\mathrm{x}$ & $\mathrm{x}$ \\
\hline 050200050103 & Pennsylvania Fork-Dunkard Creek & OHIO & 3 & $\mathrm{X}$ & $\mathrm{X}$ & $\mathrm{X}$ \\
\hline 050200050806 & Piney Fork-Peters Creek & OHIO & 3 & $\mathrm{X}$ & $\mathrm{X}$ & $\mathrm{X}$ \\
\hline 050200050807 & Fallen Timber Run-Monongahela River & OHIO & 3 & $\mathrm{X}$ & $\mathrm{x}$ & $\mathrm{X}$ \\
\hline 050200050808 & Streets Run-Monongahela River & OHIO & 3 & $\mathrm{X}$ & $\mathrm{x}$ & $\mathrm{x}$ \\
\hline 050200060801 & Headwaters Indian Creek & OHIO & 3 & $\mathrm{X}$ & $\mathrm{X}$ & $\mathrm{X}$ \\
\hline 050200060901 & Meadow Run & OHIO & 3 & $\mathrm{X}$ & $\mathrm{X}$ & $\mathrm{x}$ \\
\hline 050200061203 & Pollack Run-Youghiogheny River & OHIO & 3 & $\mathrm{X}$ & $\mathrm{x}$ & $\mathrm{X}$ \\
\hline 050301010301 & Sawmill Run & OHIO & 3 & $\mathrm{X}$ & $\mathrm{x}$ & $\mathrm{X}$ \\
\hline 050301010302 & Lowries Run & OHIO & 3 & $\mathrm{X}$ & $\mathrm{x}$ & $\mathrm{x}$ \\
\hline 050301010303 & Kilbuck Run-Ohio River & OHIO & 3 & $\mathrm{X}$ & $\mathrm{x}$ & $\mathrm{X}$ \\
\hline 050301010305 & Little Sewickley Creek & OHIO & 3 & $\mathrm{X}$ & $\mathrm{x}$ & $\mathrm{x}$ \\
\hline 050301010307 & McCabe Run-Ohio River & OHIO & 3 & $\mathrm{X}$ & $\mathrm{x}$ & $\mathrm{x}$ \\
\hline 050301010309 & Crows Run-Ohio River & OHIO & 3 & $\mathrm{X}$ & $\mathrm{X}$ & $\mathrm{X}$ \\
\hline 050301010310 & Sixmile Run-Ohio River & OHIO & 3 & $\mathrm{X}$ & $\mathrm{X}$ & $\mathrm{X}$ \\
\hline 050301010602 & Honey Creek & OHIO & 3 & $\mathrm{X}$ & $\mathrm{X}$ & $\mathrm{X}$ \\
\hline 050301010608 & Brush Run-North Fork Little Beaver Creek & OHIO & 3 & $\mathrm{X}$ & $\mathrm{X}$ & $\mathrm{X}$ \\
\hline 050301010610 & Bieler Run-Little Beaver Creek & OHIO & 3 & $\mathrm{X}$ & $\mathrm{X}$ & $\mathrm{X}$ \\
\hline 050301020104 & Frontal Pymatuning Reservoir & OHIO & 3 & $\mathrm{X}$ & $\mathrm{X}$ & $\mathrm{x}$ \\
\hline 050301020105 & Pymatuning Reservoir & OHIO & 3 & $\mathrm{X}$ & $\mathrm{X}$ & $\mathrm{X}$ \\
\hline 050301020603 & McCullough Run-Shenango River & OHIO & 3 & $\mathrm{X}$ & $\mathrm{x}$ & $\mathrm{X}$ \\
\hline 050301040102 & Brady Run & OHIO & 3 & $\mathrm{X}$ & $\mathrm{X}$ & $\mathrm{X}$ \\
\hline 050301040103 & Beaver River-Ohio River & OHIO & 3 & $\mathrm{X}$ & $\mathrm{x}$ & $\mathrm{X}$ \\
\hline 050301060502 & South Fork Dunkard Fork & OHIO & 3 & $\mathrm{X}$ & $\mathrm{x}$ & $\mathrm{X}$ \\
\hline 050301060802 & Grave Creek & OHIO & 3 & $\mathrm{X}$ & $\mathrm{x}$ & $\mathrm{X}$ \\
\hline 050301061001 & Upper West Virginia Fork Fish Creek & OHIO & 3 & $\mathrm{X}$ & $\mathrm{X}$ & $\mathrm{X}$ \\
\hline 050301061003 & Middle West Virginia Fork Fish Creek & OHIO & 3 & $\mathrm{X}$ & $\mathrm{X}$ & $\mathrm{X}$ \\
\hline 050301061101 & Pennsylvania Fork Fish Creek & OHIO & 3 & $\mathrm{X}$ & $\mathrm{X}$ & $\mathrm{X}$ \\
\hline
\end{tabular}


Table 7. Summary of watersheds exhibiting basin characteristic, geographic, and correlation gaps by 8-digit hydrologic unit code (HUC8) in Pennsylvania and New York.

[HUC12, 12-digit hydrologic unit code]

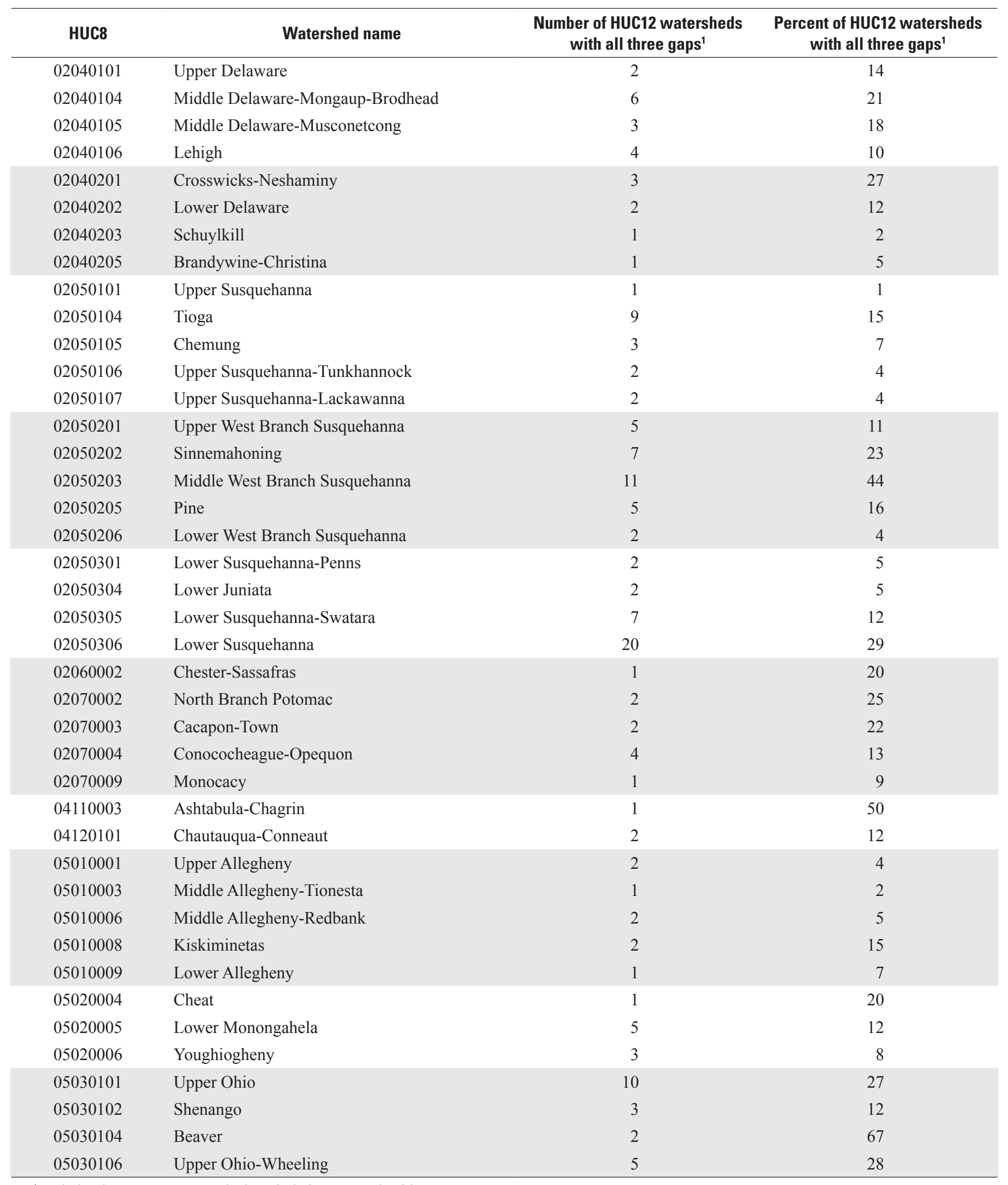

${ }^{1}$ Includes those HUC12 watersheds entirely in New York with 2 gaps. 


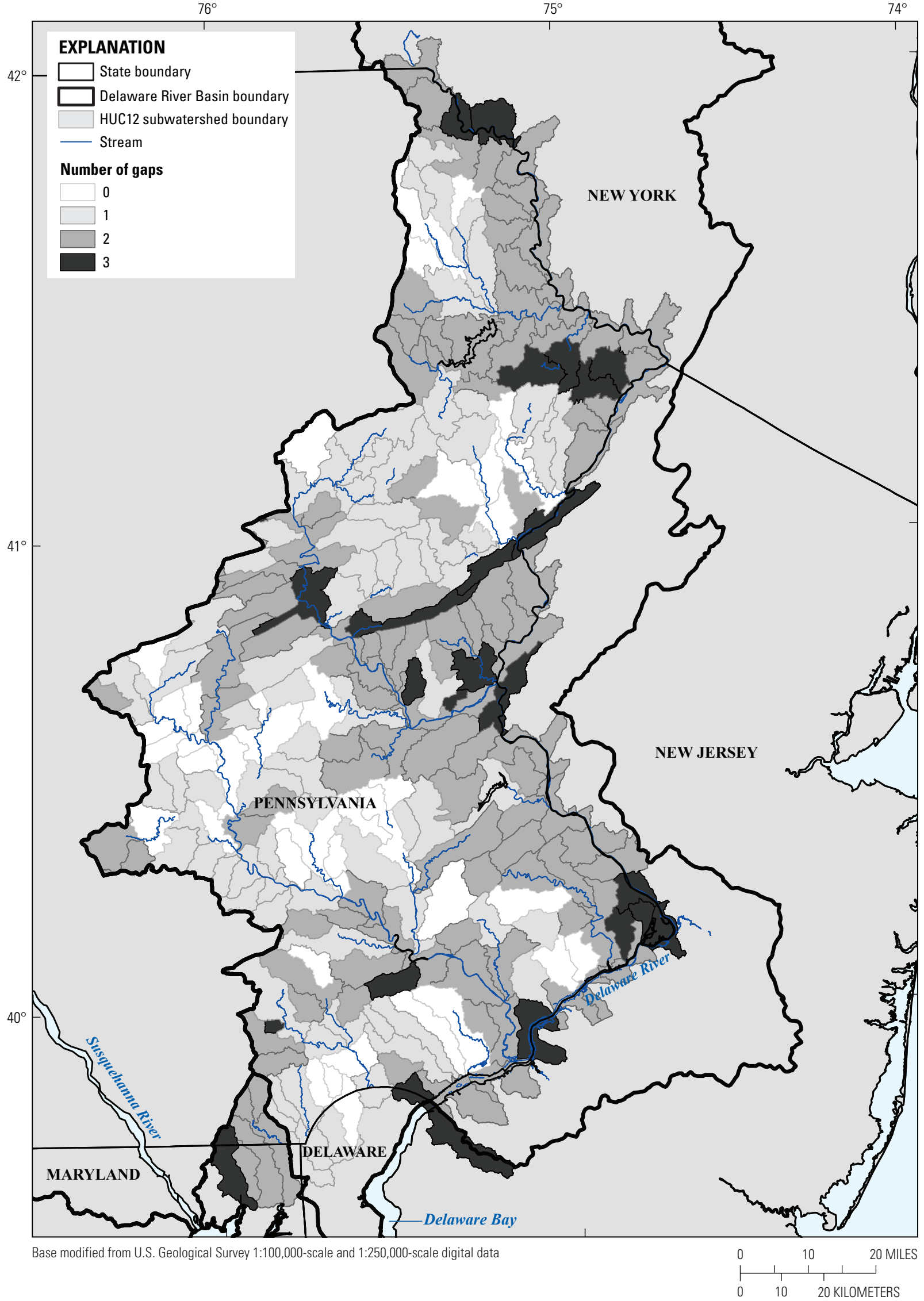

Figure 19. Location of 12-digit hydrologic unit code (HUC12) subwatersheds with basin characteristic, geographic, and correlation gaps in the Delaware River Basin. 


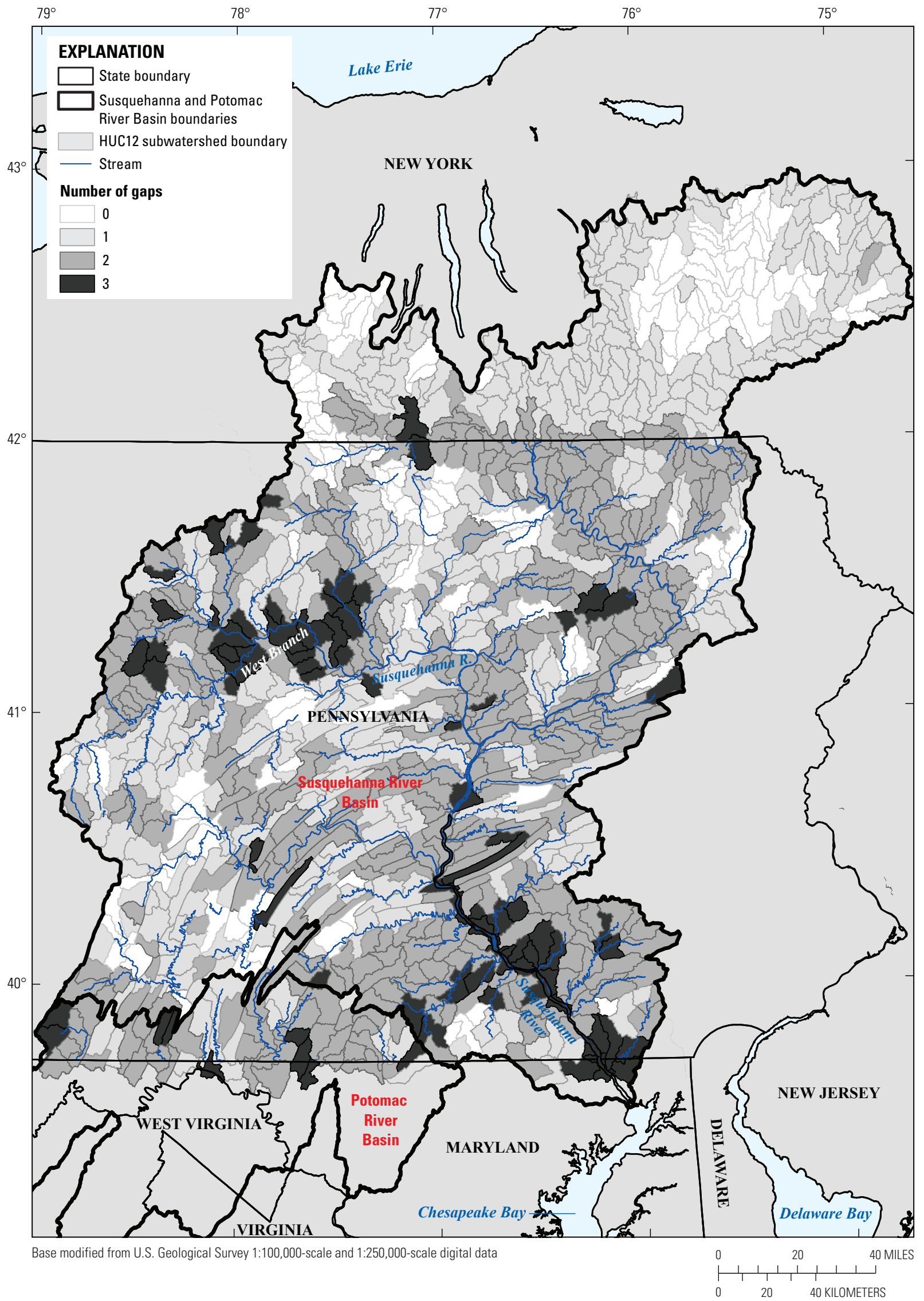

Figure 20. Location of 12-digit hydrologic unit code (HUC12) subwatersheds with basin characteristic, geographic, and correlation gaps in the Susquehanna River Basin. 


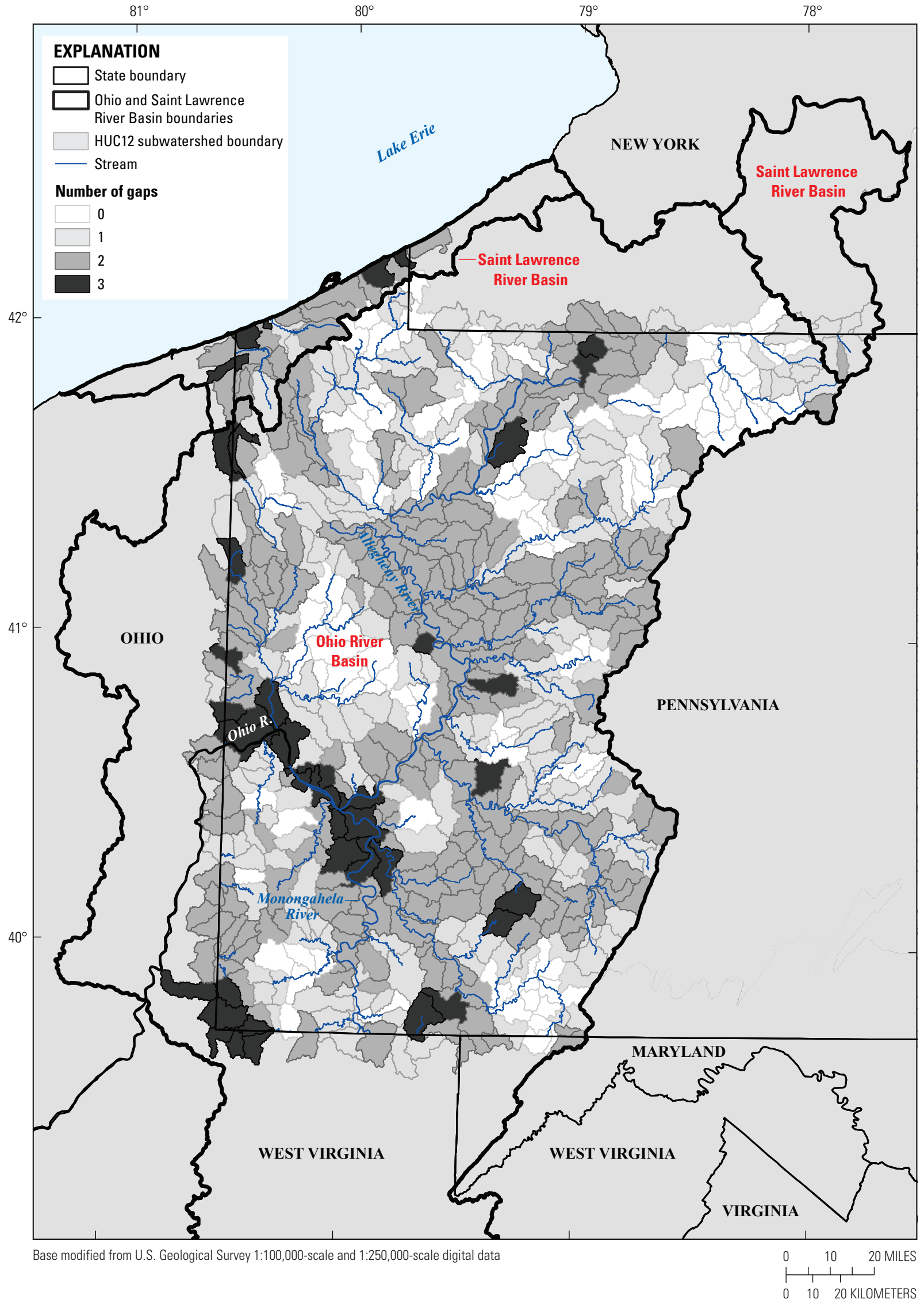

Figure 21. Location of 12-digit hydrologic unit code (HUC12) subwatersheds with basin characteristic, geographic, and correlation gaps in the Ohio River Basin. 


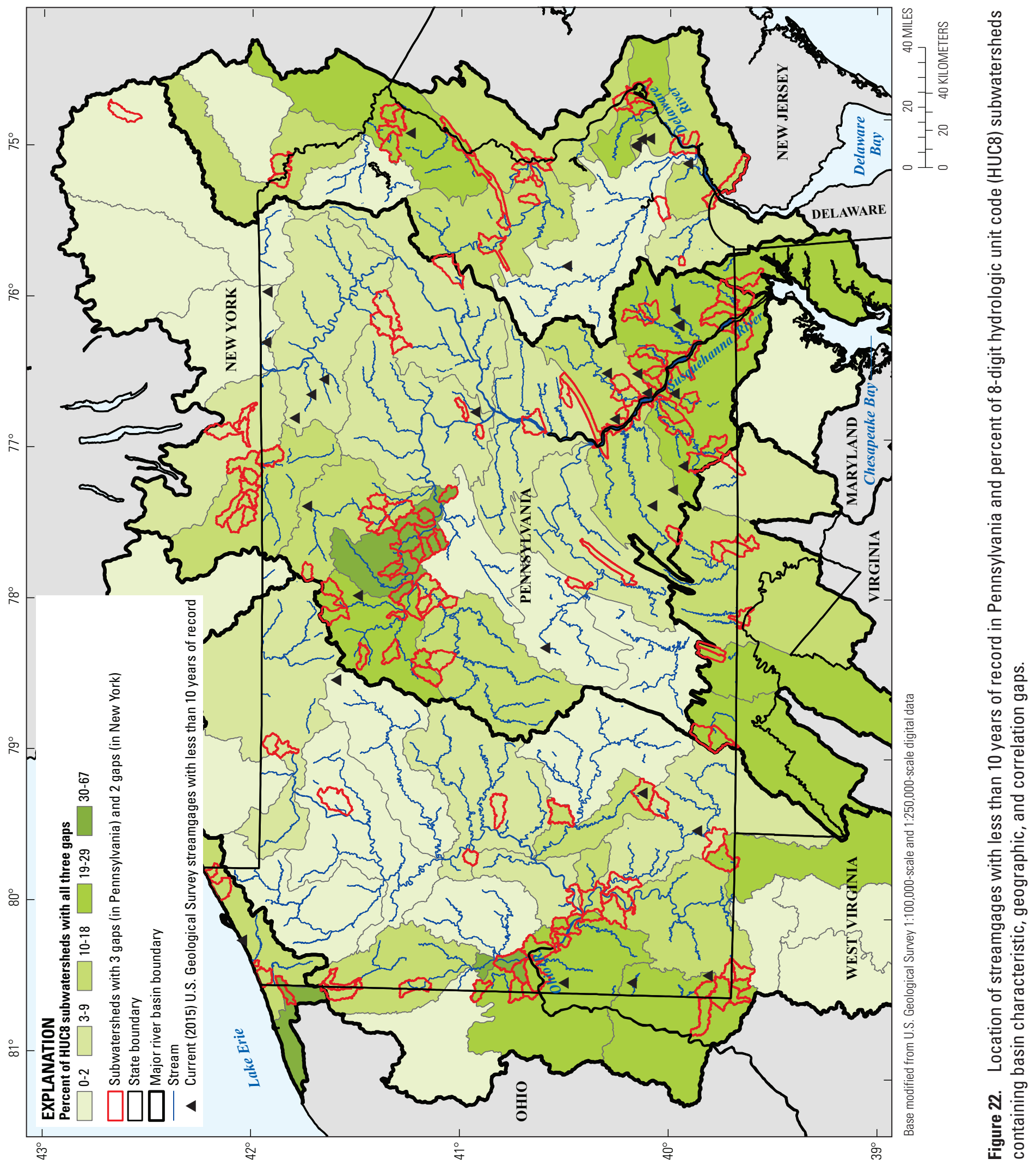




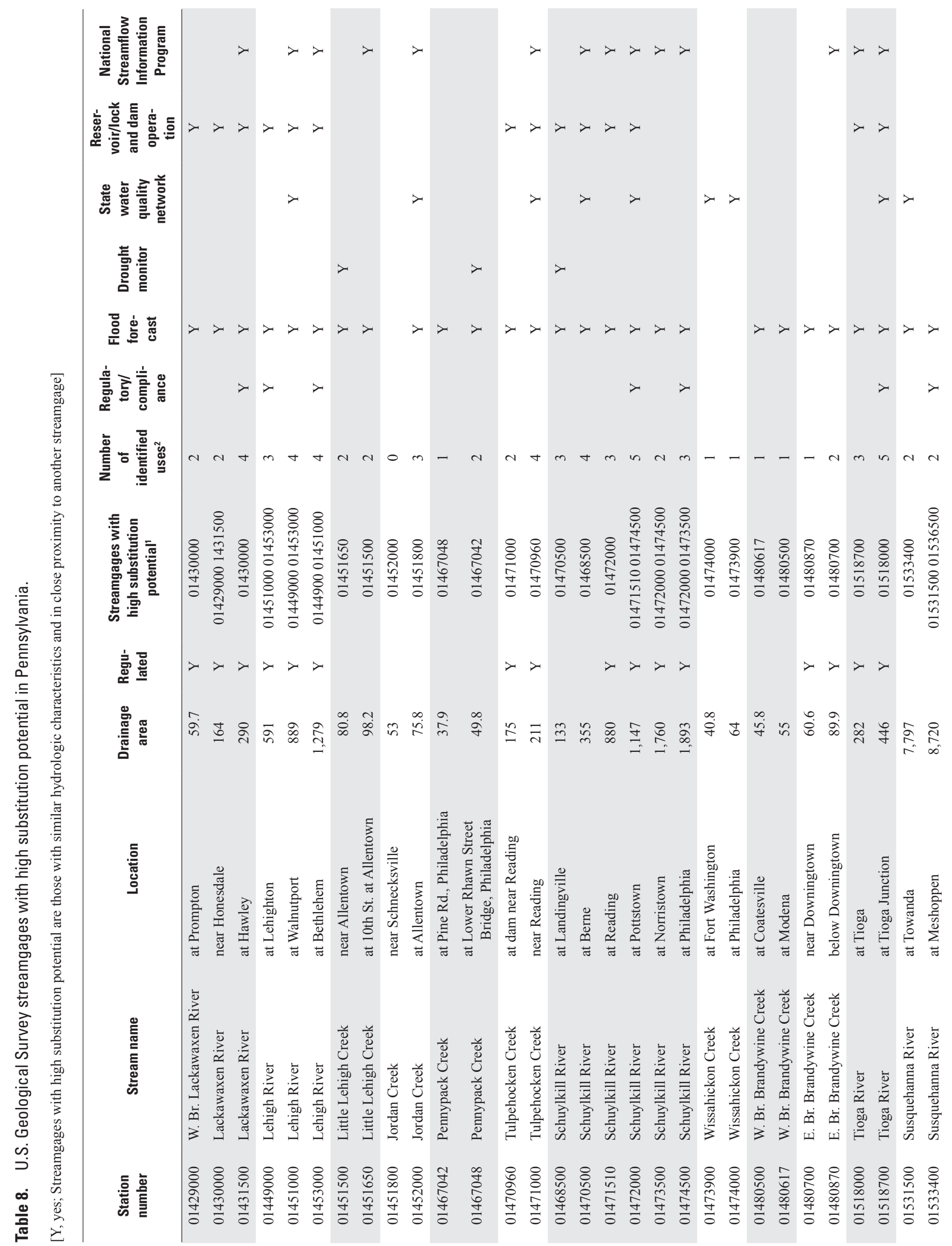




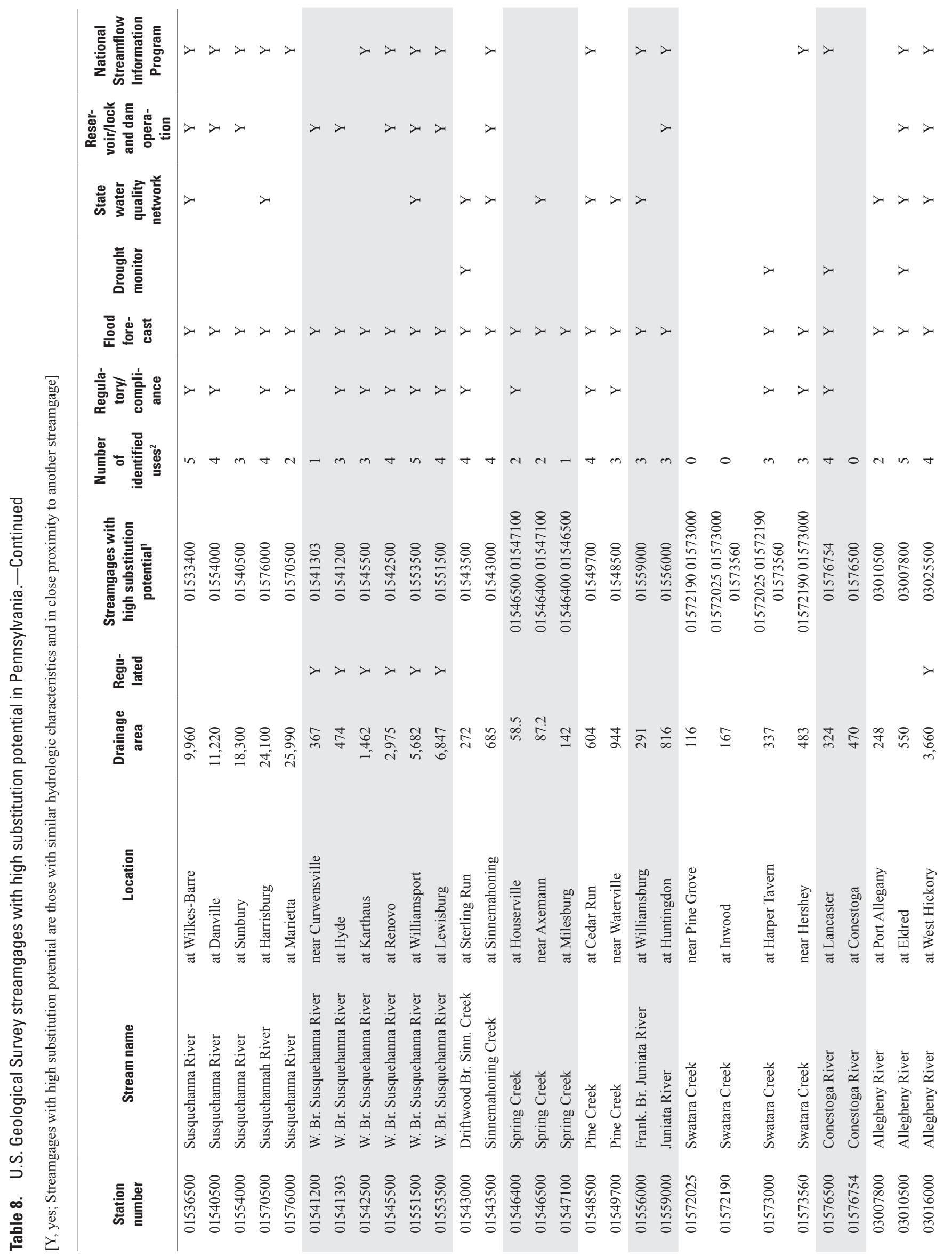




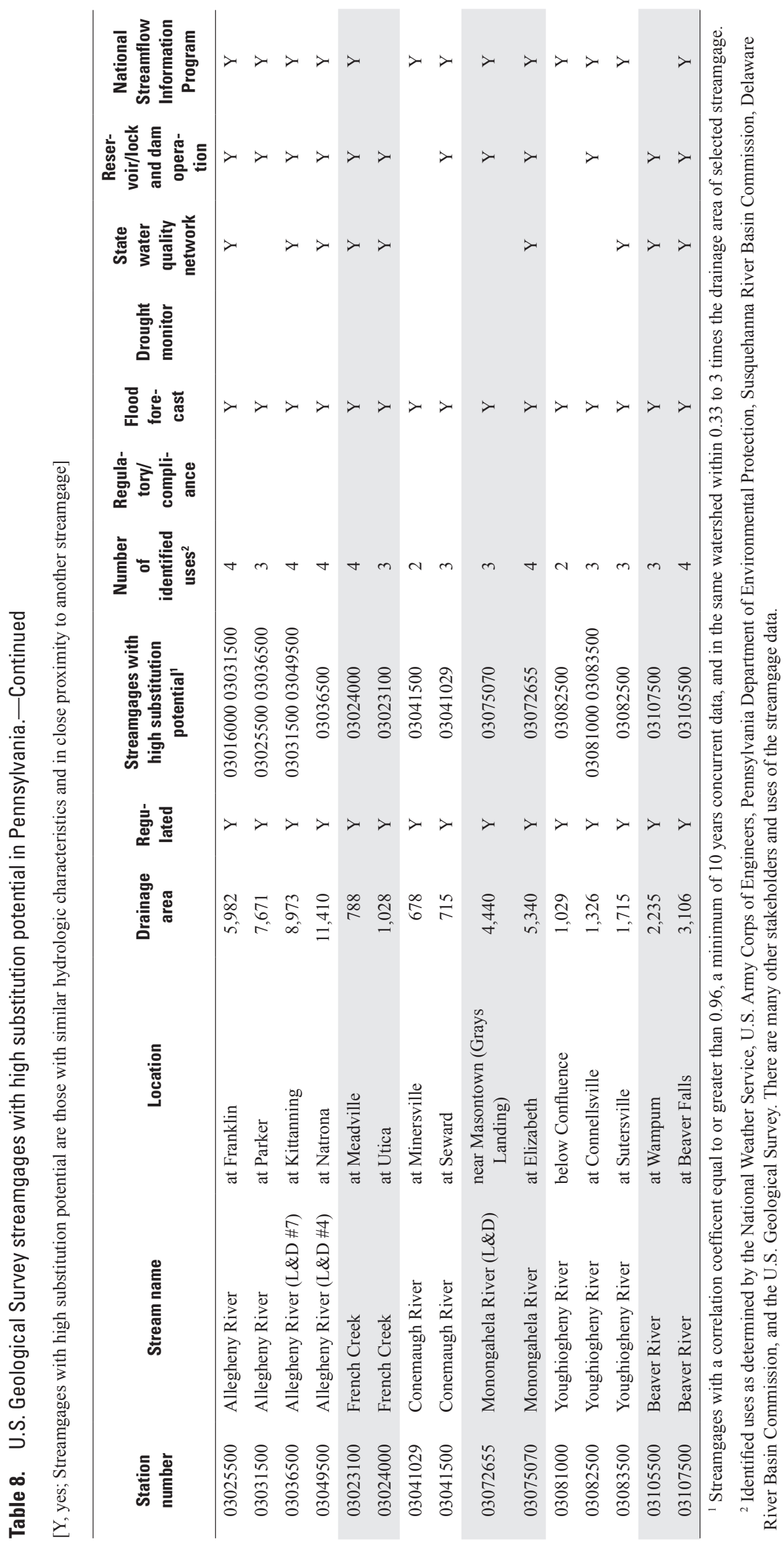




\section{Summary}

The current (2015) streamgage network in Pennsylvania and the Susquehanna River Basin in Pennsylvania and New York fulfills Federal purposes and interests and the needs of cooperating partners who require hydrologic data to manage water resources. Therefore, the streamgage network meets the needs of U.S. Geological Survey (USGS) cooperative partners but may not be ideal for establishing a reference streamgage network. In a reference streamgage network, gaged watersheds represent a composite of the upstream land cover, basin features, and hydrologic characteristics. Streamflow statistics from a reference streamgage can be transferred to ungaged watersheds with similar land cover and basin features to estimate streamflow. Although many of the current streamgages can be used as reference streamgages, an analysis was needed in order to design a network that would meet the hydrologic needs of many partners and serve various purposes and interests. The USGS, in cooperation with the Pennsylvania Department of Environmental Protection (PaDEP) and the Susquehanna River Basin Commission (SRBC), evaluated the streamgaging network for the purpose of estimating streamflow statistics at ungaged sites in Pennsylvania and the Susquehanna River Basin in Pennsylvania and New York.

The study area includes the Commonwealth of Pennsylvania and the entire Susquehanna River Basin in Pennsylvania and New York. Watersheds in the study area that are not adequately represented by a reference or current streamgage were identified by examining the range of basin characteristics, the extent of geographic coverage, and the strength of estimated streamflow correlations between gaged and ungaged sites. For this study, 229 streamgages were identified as reference streamgages. Criteria for a streamgage to be considered a reference streamgage are a minimum of 10 years of continuous record and minimally altered streamflow. Drainage basin size for a reference streamgage was limited to a maximum size of 1,500 square miles.

Basin characteristics were determined for the 229 watersheds with USGS reference streamgages using GIS spatial analysis. Basin characteristics also were determined for the 1,662 12-digit hydrologic unit code (HUC12) watersheds in Pennsylvania and the entire Susquehanna River Basin. Basin characteristics selected for this study were drainage area, mean basin elevation, mean basin slope, percentage of urbanized area, percentage of forested area, percentage of carbonate bedrock, mean annual precipitation, and soil thickness. Overall, the reference streamgages represent 80 percent of the variation in the selected basin characteristics found in the HUC12 subwatersheds. A total of 320 HUC12 subwatersheds in the study area have basin characteristics outside the range represented by the reference streamgages. The large number of headwater streams found within Pennsylvania and the Susquehanna River Basin in New York, and the unique set of basin characteristics found within these small watersheds, can make finding a representative reference streamgage challenging.

A GIS spatial analysis was used to identify geographic gaps in the streamgage network. For each streamgage, a watershed area called the gage statistical area (GSA) was delineated. The GSA shows the drainage area suitable for transfer of streamflow statistics from that streamgage to an ungaged site on the valid statistical reach (VSR) of the GSA for a streamgage. A drainage-area ratio of $0.33-0.3$ times the drainage area at the streamgage was used to define the GSA. In the study area, 1,102 HUC12 subwatersheds, or 66 percent, are outside the GSA.

The USGS Baseline Streamflow Estimator program (BaSE) was used to determine how well HUC12 subwatersheds are represented by the reference streamgage network in Pennsylvania. The centroid location of each HUC12 subwatershed was entered as an ungaged site into the BaSE program to determine the reference streamgage with the highest estimated correlation to the HUC12 watershed. Correlation coefficients ranged from 0.8896 to 0.9974 . There were $929 \mathrm{HUC12}$ subwatersheds with an estimated streamflow correlation less than or equal to 0.96 .

The results from the basin characteristics, geographic, and streamflow correlation analyses were combined to identify 1,405 HUC12 subwatersheds, or about 84 percent, in Pennsylvania and the Susquehanna River Basin in Pennsylvania and New York that had one or more gaps (lack of streamgage coverage on the basis of basin characteristic, geographic location, or estimated correlation analysis). There were 667 HUC12 subwatersheds, or 40 percent, that had two gaps, and 139 HUC12 subwatersheds, or 8 percent, that exhibited all three gaps. The Potomac River Basin had the highest percentage of HUC12 subwatersheds with three gaps at 15 percent, whereas the Ohio River Basin had the lowest percentage of watersheds with three gaps, at 8 percent.

Streamgages with similar hydrologic characteristics in close proximity to one another can potentially provide similar information and have a high substitution potential. Streamgages were considered to have high substitution potential if (1) the streamflow correlation coefficient was equal to or greater than $0.96,(2)$ the streamgages had 10 years of concurrent record, and (3) the streamgages are in the same watershed within one-third to three times the drainage area at the streamgage. Seventy-four streamgages with high substitution potential were identified. Six selected primary uses for these streamgages were identified to help evaluate the overall need of an individual streamgage. 


\section{References Cited}

Archfield, S. A., and R. M. Vogel, 2010, Map correlation method: Selection of a reference streamgage to estimate daily streamflow at ungaged catchments: Water Resources Research, no. 46, W10513, doi:10.1029/2009WR008481.

Barnes, C.R., 1986, Method for estimating low-flow statistics for ungaged streams in the lower Hudson River Basin, New York: U.S. Geological Survey Water-Resources Investigations Report 85-4070, 22 p., at http://pubs.usgs. gov/wri/1985/4070/report.pdf.

Bisese, J.A., 1995 Methods for estimating the magnitude and frequency of peak discharges of rural, unregulated streams in Virginia: U.S. Geological Survey Water-Resources Investigations Report 94-4148, 70 p.

Choquette, A.F., 1988, Regionalization of peak discharges for streams in Kentucky: U.S. Geological Survey WaterResources Investigations Report 87-4209, 105 p.

Durlin, R.R., 2009, Streamgaging in Pennsylvania: 18832009: U.S. Geological Survey Fact Sheet 2009-3048, 4 p., at http://pubs.usgs.gov/fs/2009/3048/pdf/fs2009-3048.pdf.

Fry, J., Xian, G., Jin, S., Dewitz, J., Homer, C., Yang, L., Barnes, C., Herold, N., and Wickham, J., 2011, Completion of the 2006 National Land Cover Database for the conterminous United States: Photogrammetric Engineering and Remote Sensing, v. 77, no. 9, p. 858-864.

Helsel, D.R., and Hirsch, R.M., 1992, Studies in environmental science 49-Statistical methods in water resources: Amsterdam, Elsevier, 522 p.

Horizon Systems, Inc., 2010, NHDPlus User Guide: Horizon Systems Corporation, 115 p., accessed December 14, 2016, at ftp://ftp.horizon-systems.com/NHDPlus/NHDPlusV1/ documentation/NHDPLUSV1_UserGuide.pdf.

Horizon Systems, Inc., 2014, NHDPlus home: Horizon Systems Corporation, accessed October 9, 2014, at http:// www.horizon-systems.com/NHDPlus/index.php.

Lumia, Richard, Freehafer, D.A., and Smith, M.J., 2006, Magnitude and frequency of floods in New York: U.S. Geological Survey Scientific Investigations Report 2006-5112, 152 p., at http://pubs.usgs.gov/sir/2006/5112/ SIR2006-5112.pdf.

Miles, C.E., and Whitfield, T.G., comps., 2001, Bedrock geology of Pennsylvania: Pennsylvania Geological Survey, 4th ser., digital dataset, scale 1:250,000.
Pearson, Karl, 1896, Mathematical contributions to the theory of evolution: Philosophical Transactions of the Royal Society of London, p. 253-318.

PRISM Group at Oregon State University, 2012, United States average monthly or annual precipitation, 1981-2010: PRISM Group at Oregon State University digital data, accessed August 20, 2013, at http://prism.oregonstate.edu.

Randall, A.D., 2010, Low flow of streams in the Susquehanna River basin of New York: U.S. Geological Survey Scientific Investigations Report 2010-5063, 57 p., at http://pubs.usgs. gov/sir/2010/5063.

Ries, K.G., III, and Friesz, P.J., 2000, Methods for estimating low-flow statistics for Massachusetts streams: U.S. Geological Survey Scientific Investigations Report 20004135, 81 p., at http://pubs.usgs.gov/wri/wri004135/pdf/ report.pdf.

Risser, D.W., Thompson, R.E., and Stuckey, M.H., 2008, Regression method for estimating long-term mean annual ground-water recharge rates from base flow in Pennsylvania: U.S. Geological Survey Scientific Investigations Report 2008-5185, 23 p., at http://pubs.usgs. gov/sir/2008/5185/pdf/sir2008-5185.pdf.

Roland, M.A., and Stuckey, M.H., 2008, Regression equations for estimating flood flows at selected recurrence intervals for ungaged streams in Pennsylvania: U.S. Geological Survey Scientific Investigations Report 2008-5102, 57 p., at http://pubs.usgs.gov/sir/2008/5102/pdf/sir2008-5102.pdf.

Seaber, P.R., Kapinos, F.P., and Knapp, G.L., 1987, Hydrologic unit maps: U.S. Geological Survey Water Supply Paper 2294, 63 p., at http://pubs.usgs.gov/wsp/ wsp2294/pdf/wsp_2294.pdf.

Stedfast, D.A., 1986, Evaluation of six methods for estimating magnitude and frequency of peak discharges on urban streams in New York: U.S. Geological Survey WaterResources Investigations Report 84-4350, 24 p., at http:// pubs.usgs.gov/wri/1984/4350/report.pdf.

Stuckey, M.H., 2006, Low-flow, base-flow, and mean-flow regression equations for Pennsylvania Streams: U.S. Geological Survey Scientific Investigations Report 20065130, 84 p., at http://pubs.usgs.gov/sir/2006/5130/pdf/ sir2006-5130.pdf.

Stuckey, M.H., and Hoffman, S.A., 2010, Pennsylvania StreamStats-A web-based application for obtaining waterresource-related information: U.S. Geological Survey Fact Sheet 2010-3086, 2 p., accessed December 14, 2016, at https://pubs.er.usgs.gov/publication/fs20103086. 
Stuckey, M.H., Koerkle, E.H., and Ulrich, J.E., 2012, Estimation of baseline daily mean streamflows for ungaged locations on Pennsylvania streams, water years 1960-2008: U.S. Geological Survey Scientific Investigations Report 2012-5142, 61 p., at http://pubs.usgs.gov/sir/2012/5142/.

Stuckey, M.H., and Reed, L.A., 2000, Techniques for estimating magnitude and frequency of peak flows for Pennsylvania streams: U.S. Geological Survey WaterResources Investigations Report 2000-4189, 43 p., at http:/pa.water.usgs.gov/reports/wrir_00-4189.pdf.

Stuckey, M.H., and Roland, M.A., 2011, Selected streamflow statistics for streamgage locations in and near Pennsylvania: U.S. Geological Survey Scientific Investigations Report 2011-1070, 88 p., at http://pubs.usgs.gov/of/2011/1070/support/of2011-1070.pdf.

TIBCO Software Inc., 2008, TIBCO Spotfire S+ 8.1 Guide to Packages: Palo Alto, Calif., 77 p.

U.S. Department of Agriculture, 1994, State soil geographic (STATSGO) data base: Washington, D.C., Miscellaneous Publication Number 1492, 33 p., accessed June 19, 2012, at http://ned.usgs.gov/downloads.asp.

U.S. Geological Survey, 2013, National Elevation Dataset, accessed June 1, 2010, at http://ned.usgs.gov/downloads. asp.

U.S. Geological Survey, 2014a, Delaware geological map data, accessed October 28, 2014, at http://mrdata.usgs.gov/ geology/state/state.php?state=DE.
U.S. Geological Survey, 2014b, Maryland geological map data, accessed October 28, 2014, at http://mrdata.usgs.gov/ geology/state/state.php?state=MD.

U.S. Geological Survey, 2014c, New Jersey geological map data, accessed October 28, 2014, at http://mrdata.usgs.gov/ geology/state/state.php?state $=$ NJ.

U.S. Geological Survey, 2014d, New York geological map data, accessed October 28, 2014, at http://mrdata.usgs.gov/ geology/state/state.php?state $=$ NY.

U.S. Geological Survey, 2014e, Ohio geological map data, accessed October 28, 2014, at http://mrdata.usgs.gov/geology/state/state.php?state $=\mathrm{OH}$.

U.S. Geological Survey, 2014f, West Virginia geological map data, accessed October 28, 2014, at http://mrdata.usgs.gov/ geology/state/state.php?state $=\mathrm{WV}$.

U.S. Geological Survey, 2014g, National Streamflow Information Program (NSIP), accessed October 29, 2014, at http://water.usgs.gov/nsip/.

U.S. Geological Survey and U.S. Department of Agriculture, Natural Resources Conservation Service, 2013, Federal standards and procedures for the National Watershed Boundary Dataset (WBD) (4 ed.): U.S. Geological Survey Techniques and Methods 11-A3, 63 p., accessed December 14, 2016, at https://pubs.usgs.gov/tm/11/a3/pdf/tm11-a3. pdf. 
Appendixes 1-6 
Appendix 1. Matrix of basin characteristics at U.S. Geological Survey reference streamgages in $A$, Delaware River Basin, $B$, Susquehanna and Potomac River Basins, and $\mathcal{C}$, Ohio and Saint Lawrence River Basins in Pennsylvania and New York.

\section{A. Delaware River Basin}

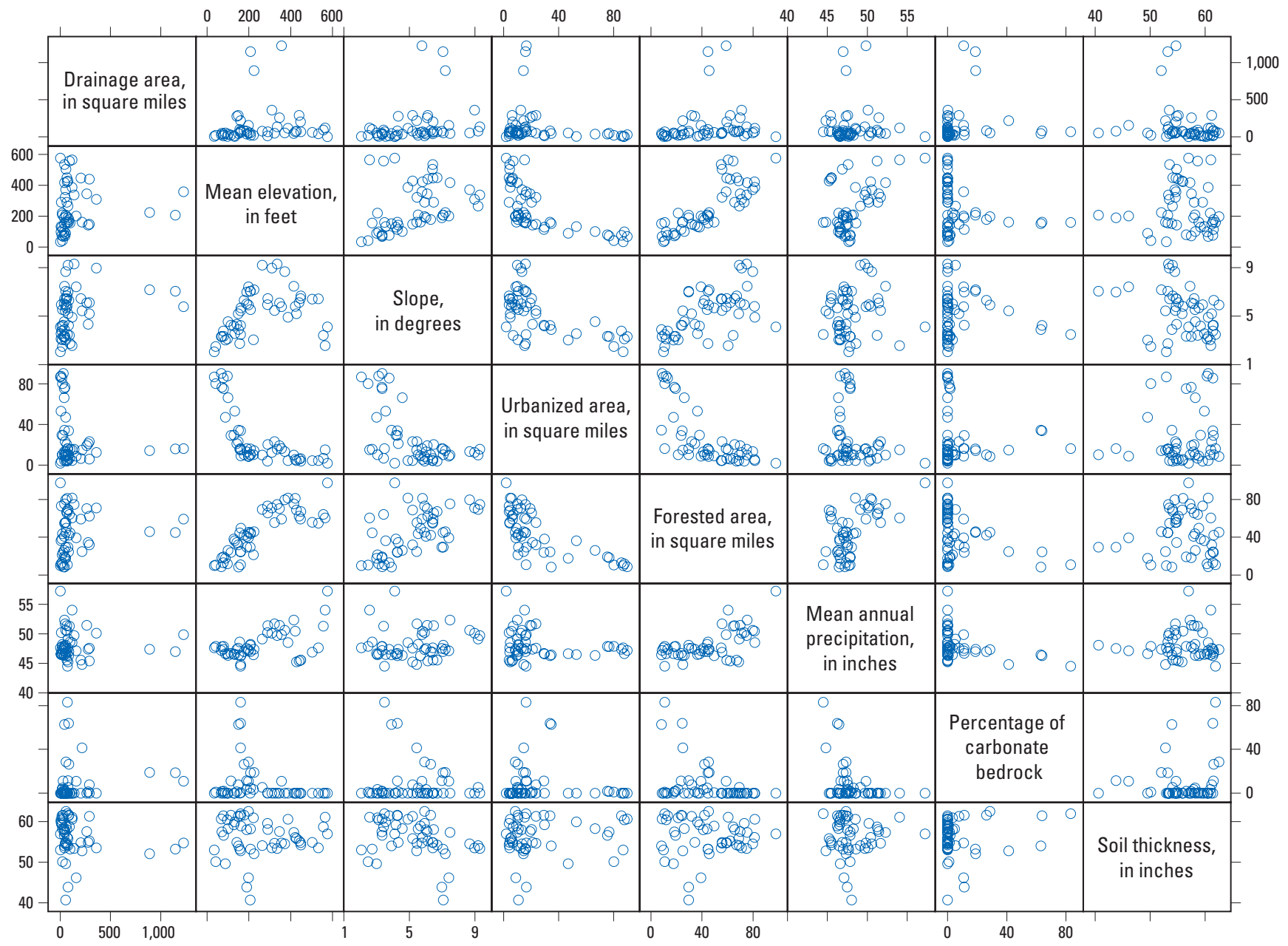


Appendix 1. Matrix of basin characteristics at U.S. Geological Survey reference streamgages in $A$, Delaware River Basin, $B$, Susquehanna and Potomac River Basins, and $C$, Ohio and Saint Lawrence River Basins in Pennsylvania and New York.

- Continued

\section{B. Susquehanna and Potomac River Basins}

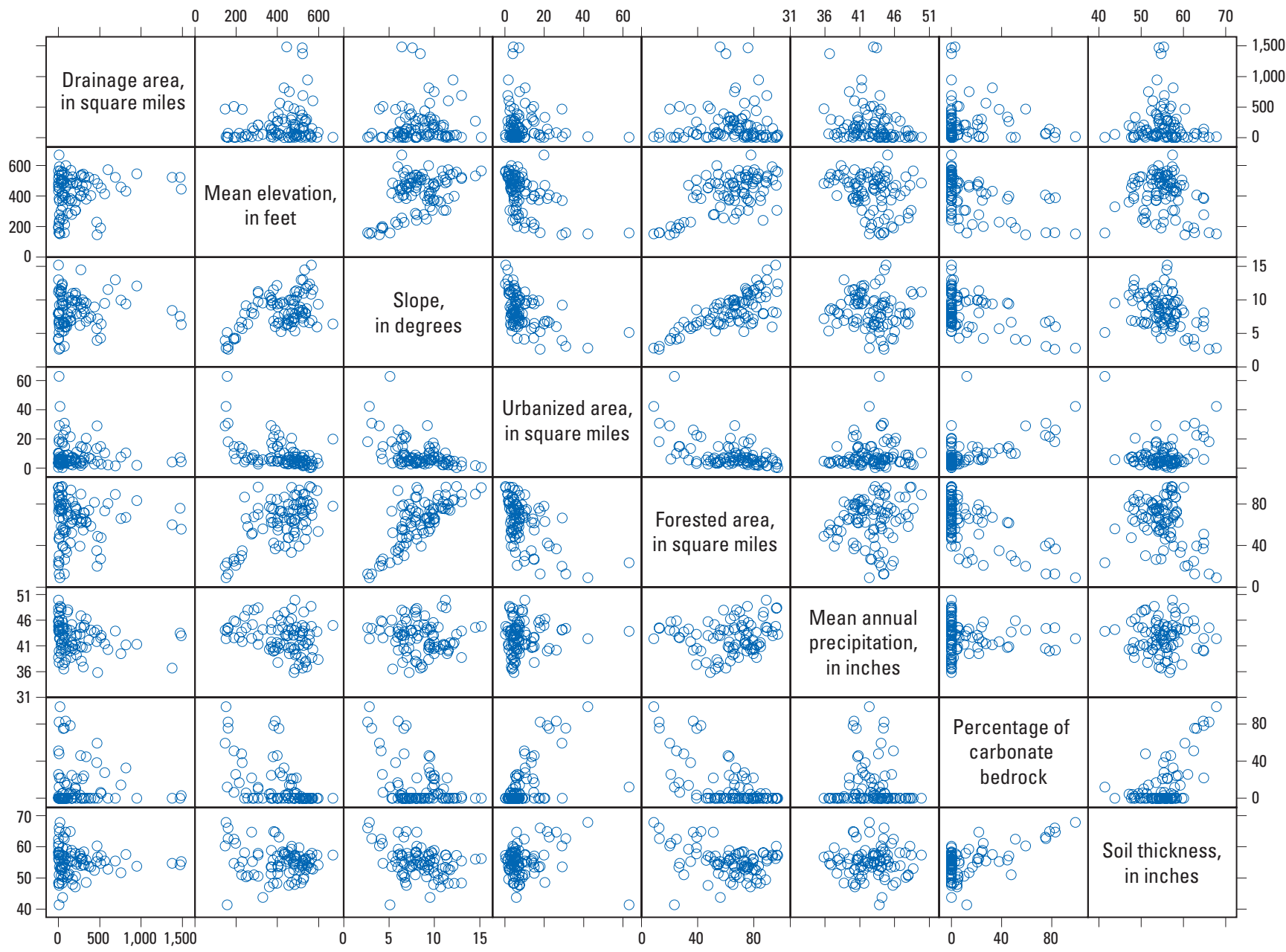


Appendix 1. Matrix of basin characteristics at U.S. Geological Survey reference streamgages in $A$, Delaware River Basin, $B$, Susquehanna and Potomac River Basins, and $\mathcal{C}$, Ohio and Saint Lawrence River Basins in Pennsylvania and New York.

-Continued

\section{Ohio and Saint Lawrence River Basins}

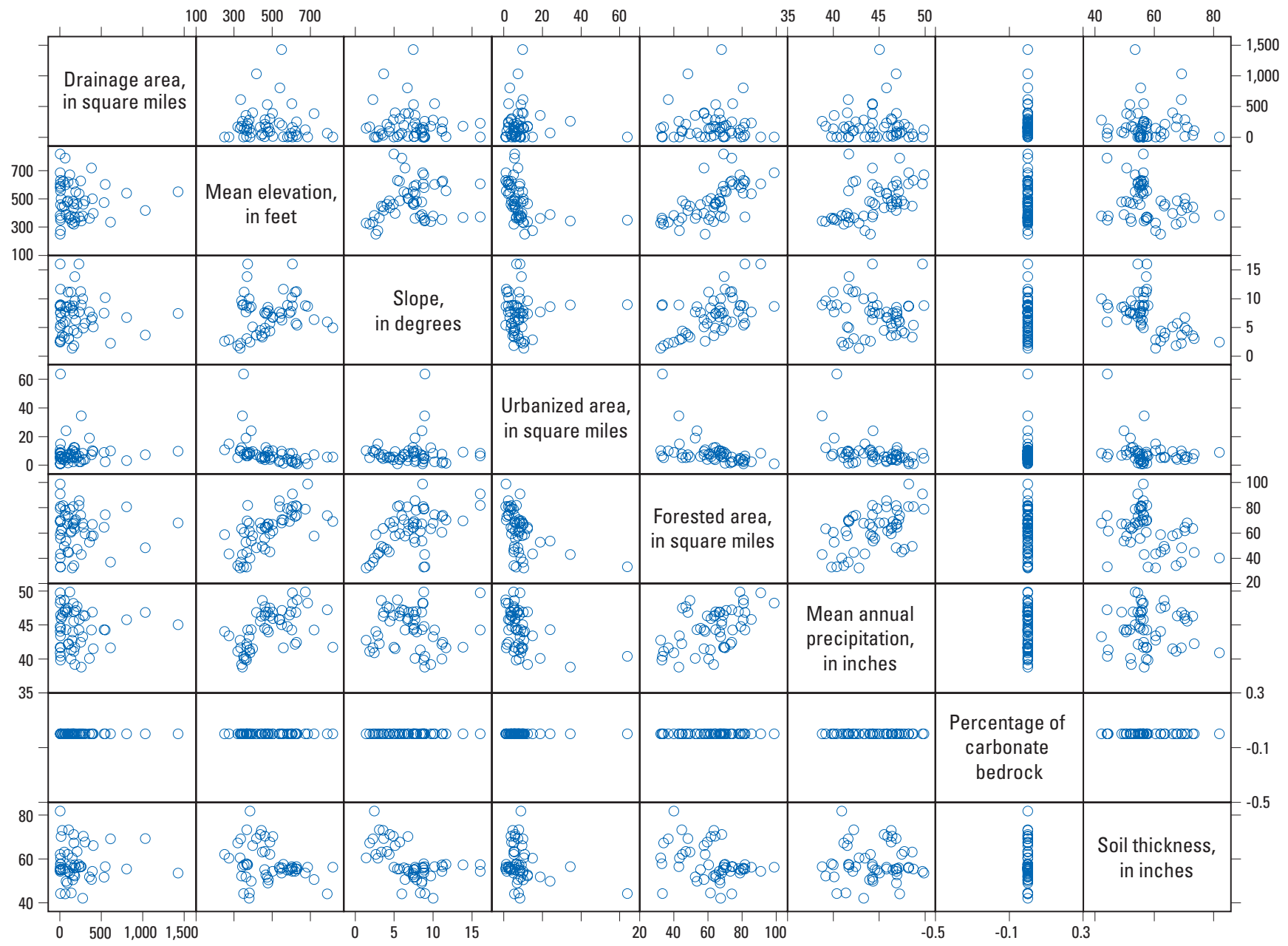




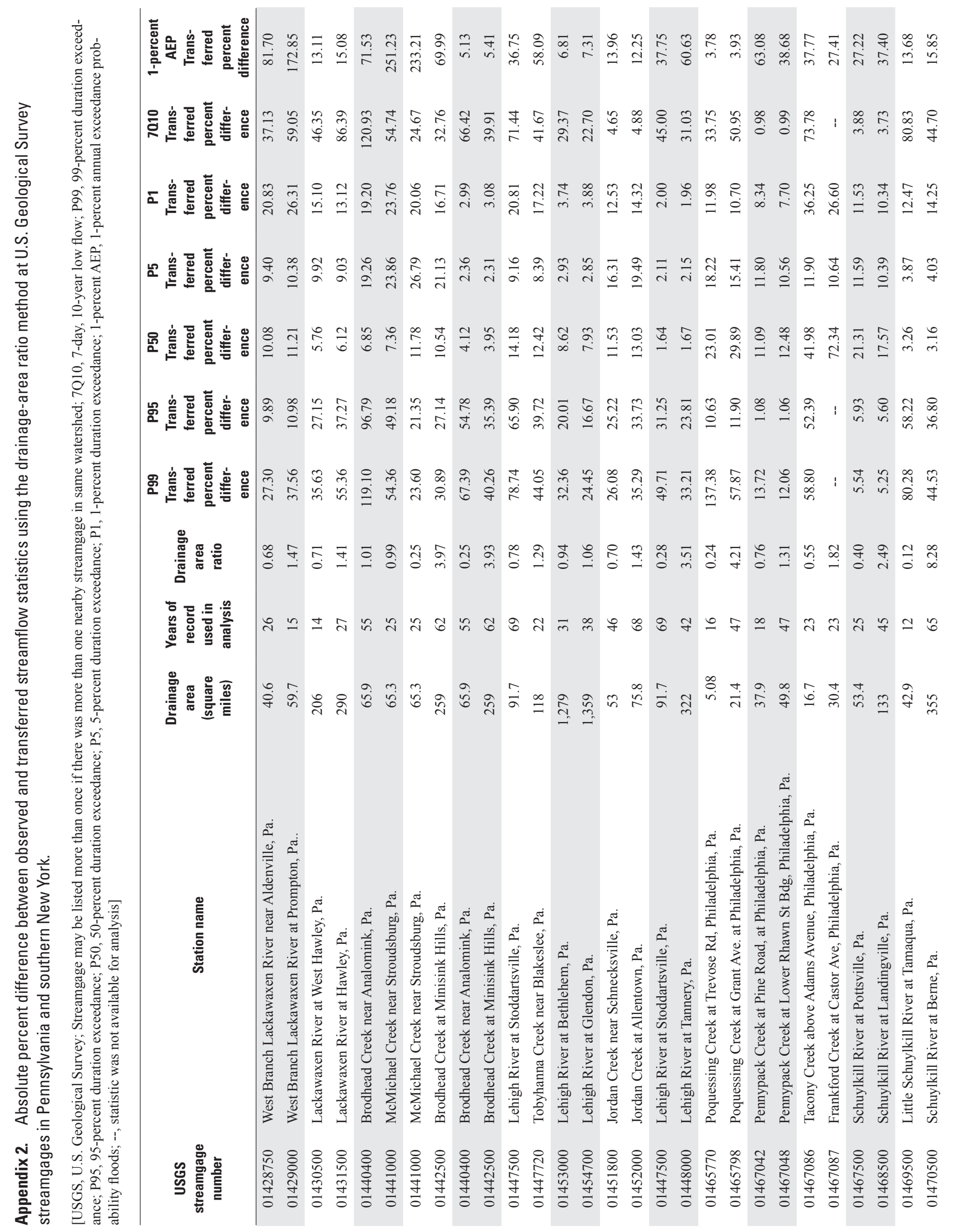




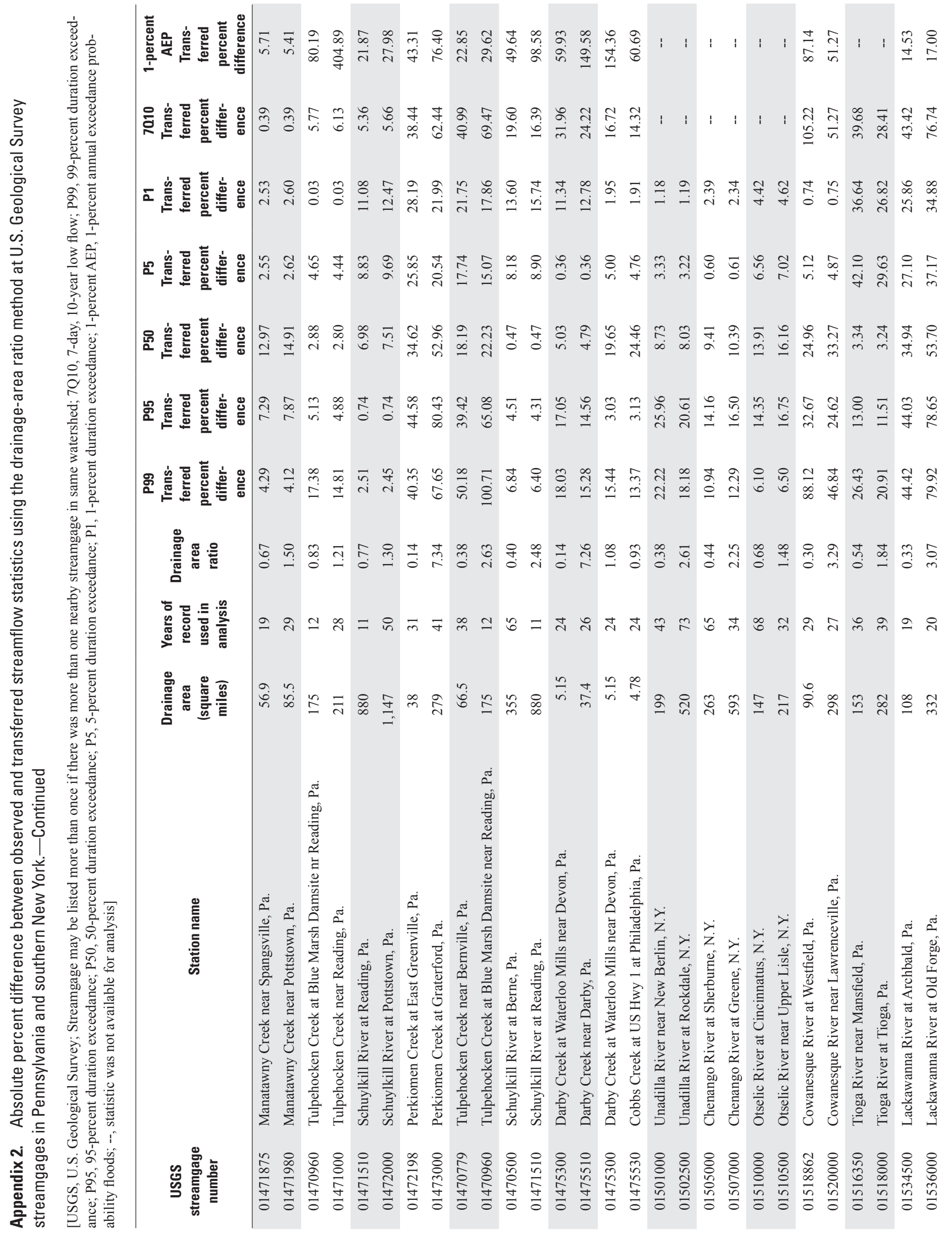




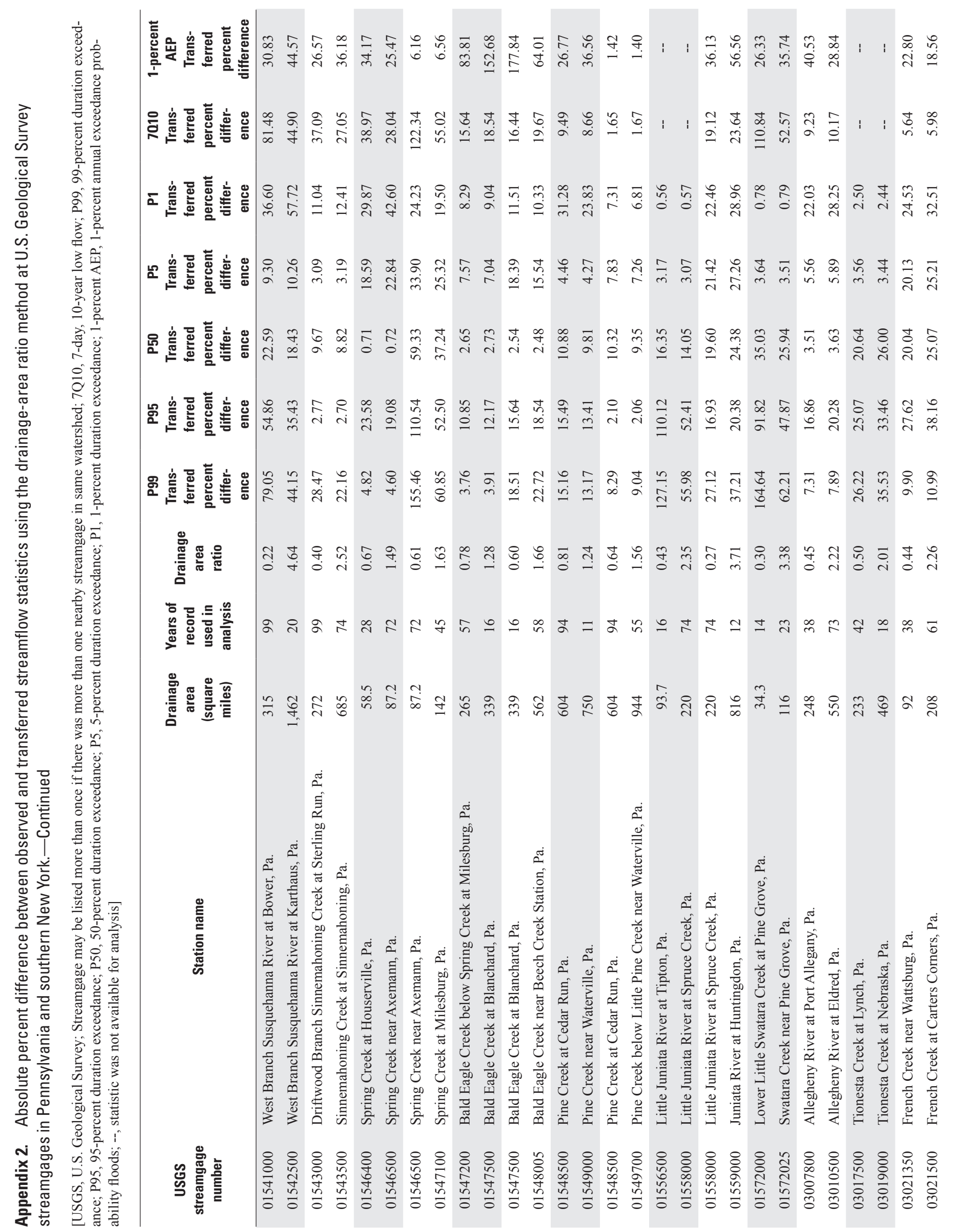




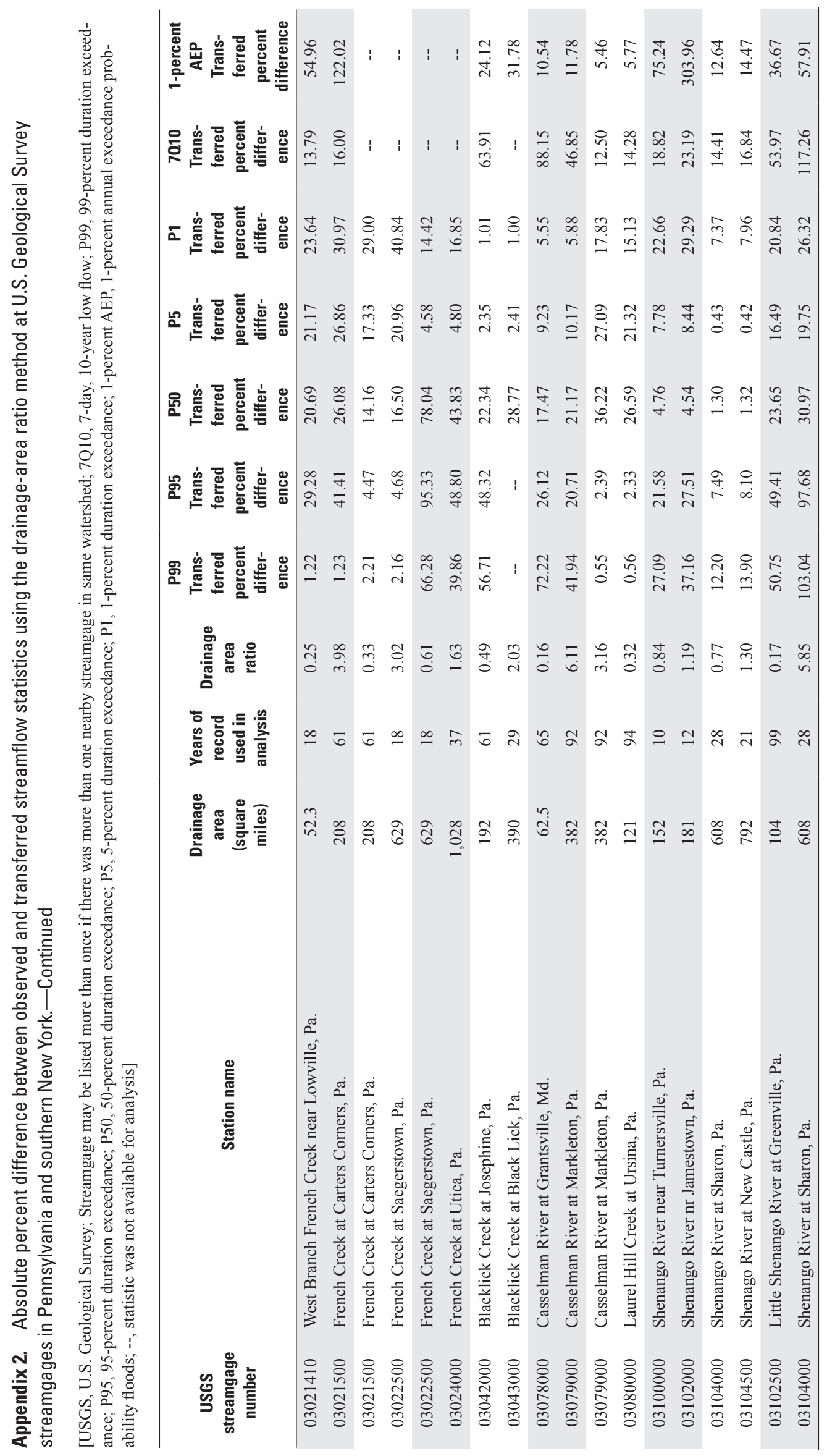



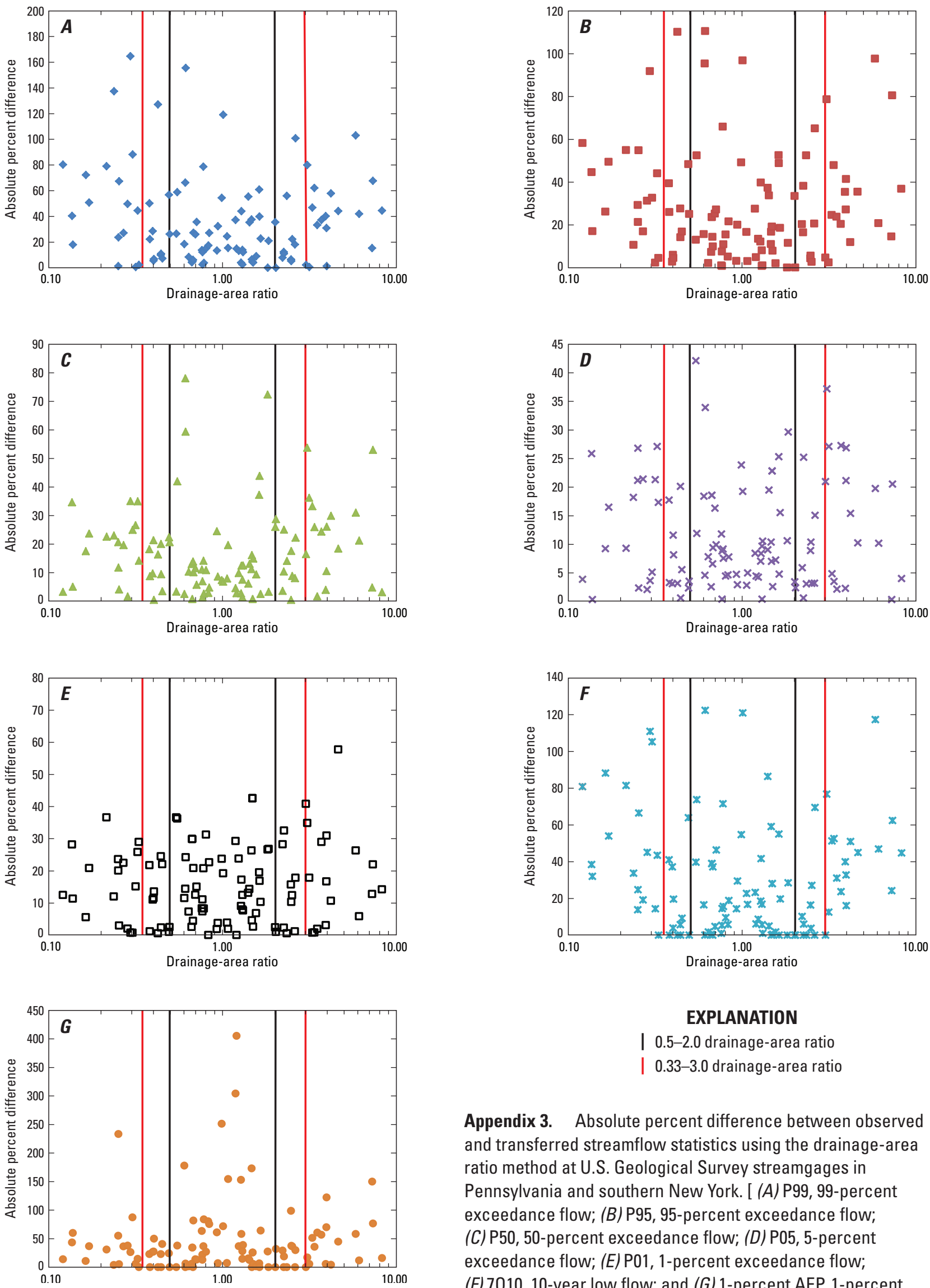

\section{EXPLANATION}

I 0.5-2.0 drainage-area ratio | 0.33-3.0 drainage-area ratio

Appendix 3. Absolute percent difference between observed and transferred streamflow statistics using the drainage-area ratio method at U.S. Geological Survey streamgages in Pennsylvania and southern New York. [ (A) P99, 99-percent exceedance flow; $(B)$ P95, 95-percent exceedance flow; (C) P50, 50-percent exceedance flow; (D) P05, 5-percent exceedance flow; (E) P01, 1-percent exceedance flow; (F) 7010, 10-year low flow; and (G) 1-percent AEP, 1-percent annual exceedance probability flood flow] 


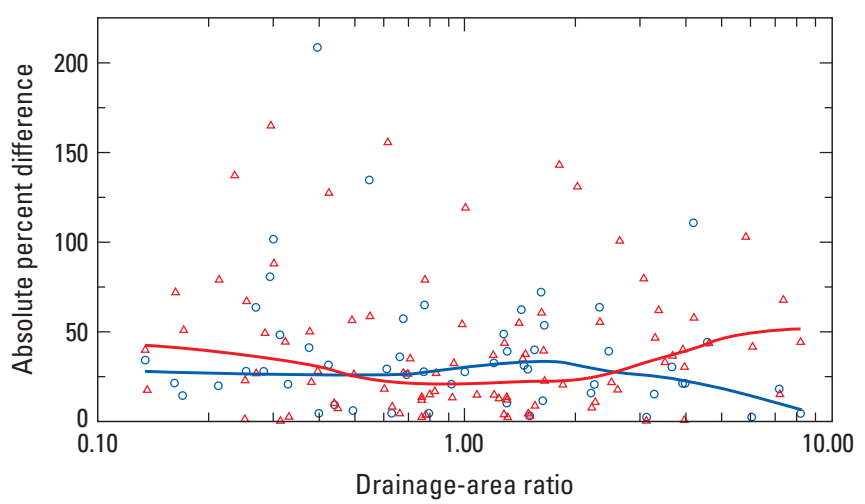

P99

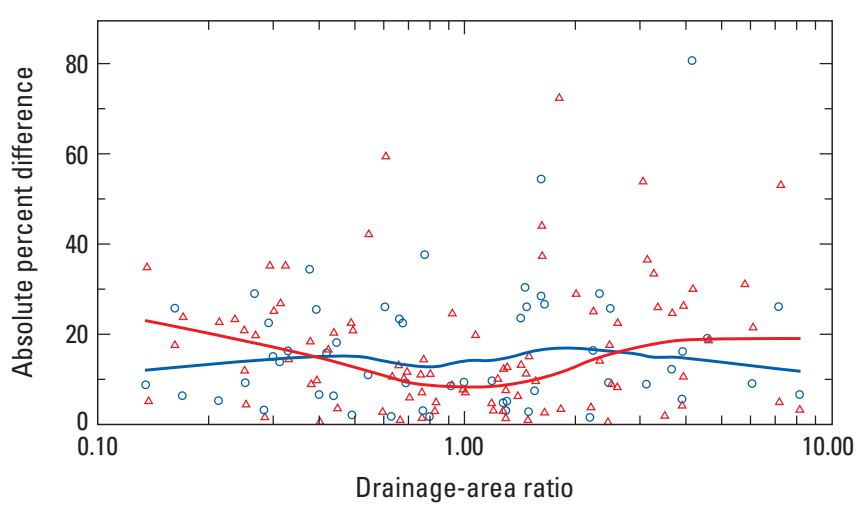

P50
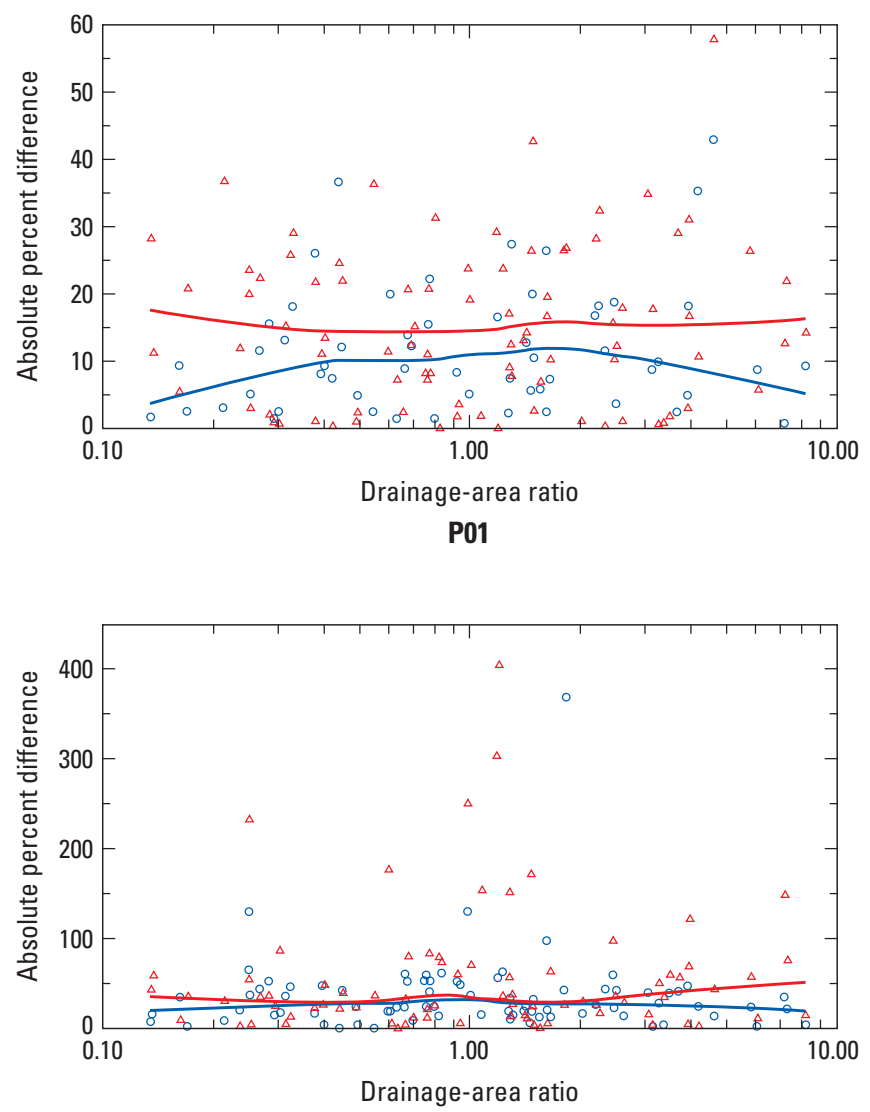

0100

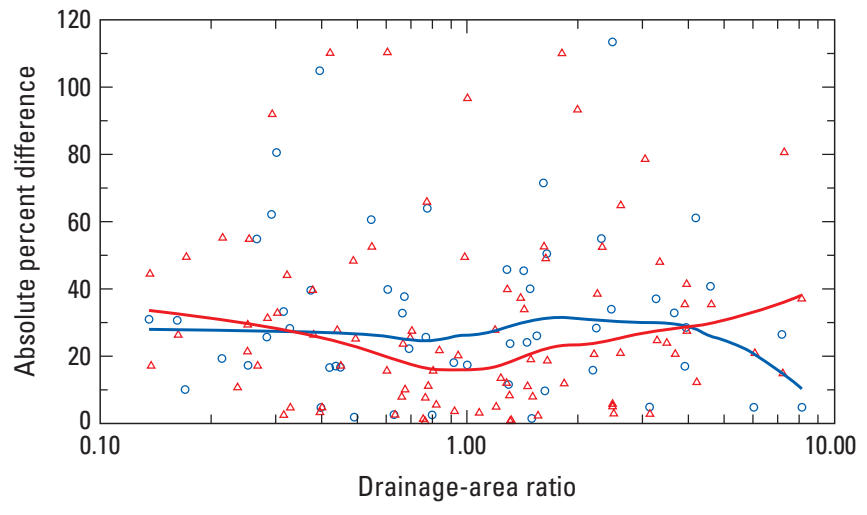

P95

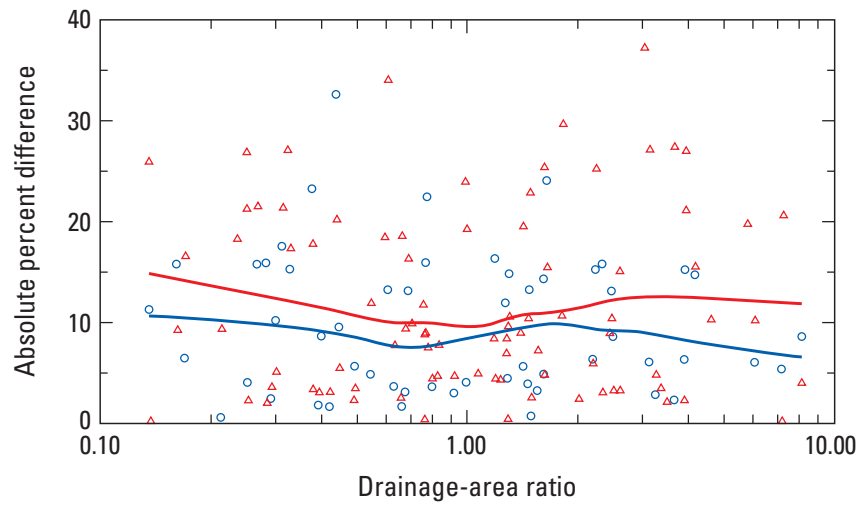

P05

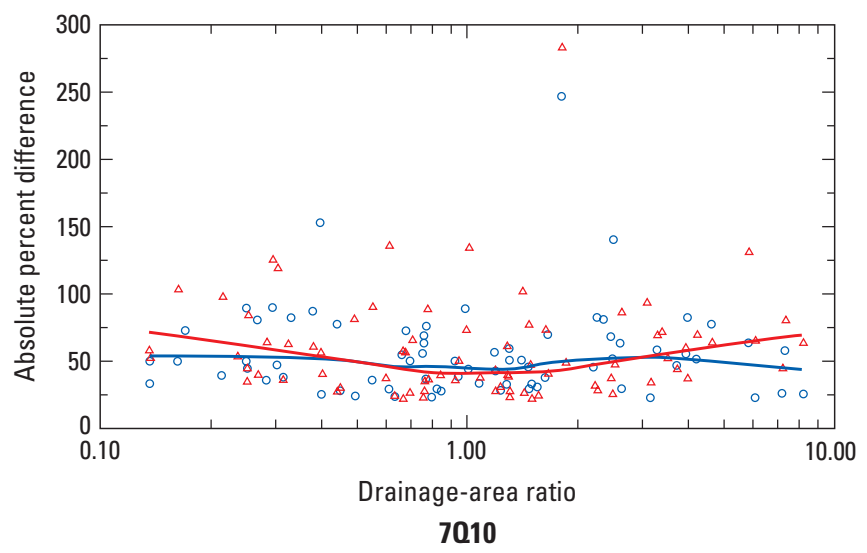

\section{EXPLANATION}

treamflow statistics estimated from regression equations

$\multimap-$ Transferred streamflow statistics

Appendix 4. Relation of drainage-area ratio to absolute percent difference for transferred and computed streamflow statistics for watersheds in Pennsylvania and the Susquehanna River Basin in Pennsylvania and New York. [P99, 99-percent exceedance flow; P95, 95-percent exceedance flow; P50, 50-percent exceedance flow; P05, 5-percent exceedance flow; P01, 1-percent exceedance flow; 7010, 7-day 10-year low flow; and 0100, 100-year flood] 
Appendix 5. Complete listing of HUC12 watersheds in Pennsylvania and the Susquehanna River Basin in Pennsylvania and New York with basin characteristic, geographic, or streamflow correlation gaps.

[HUC12, 12-digit hydrologic unit code; DEL, Delaware River Basin; STLAW, Saint Lawrence River Basin; OHIO, Ohio River Basin; POT, Potomac River Basin; SUSQ, Susquehanna River Basin; SUSQ NY, Susquehanna River Basin watersheds entirely in New York; X, indicates gap]

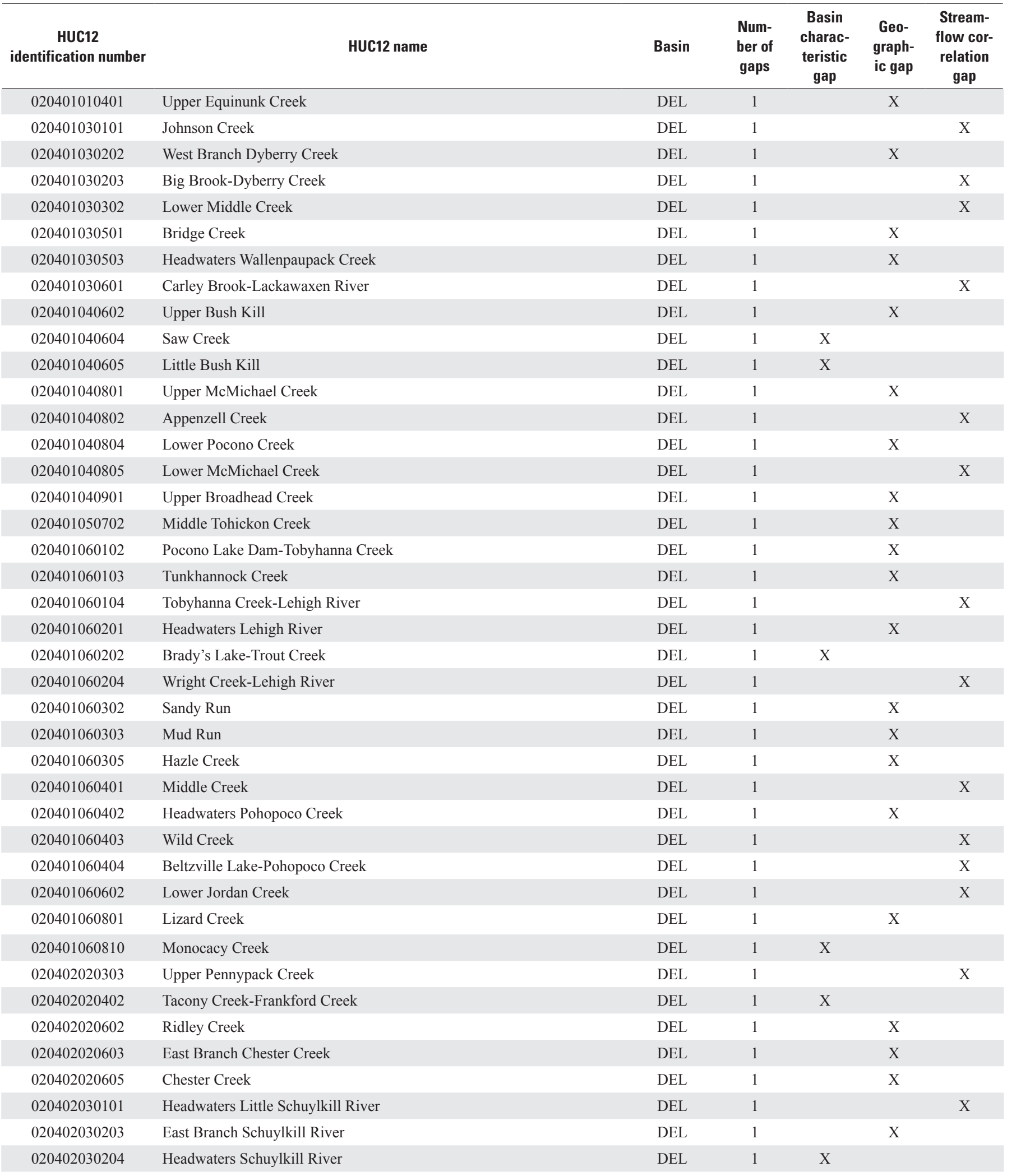


Appendix 5. Complete listing of HUC12 watersheds in Pennsylvania and the Susquehanna River Basin in Pennsylvania and New York with basin characteristic, geographic, or streamflow correlation gaps.-Continued

[HUC12, 12-digit hydrologic unit code; DEL, Delaware River Basin; STLAW, Saint Lawrence River Basin; OHIO, Ohio River Basin; POT, Potomac River Basin; SUSQ, Susquehanna River Basin; SUSQ NY, Susquehanna River Basin watersheds entirely in New York; X, indicates gap]

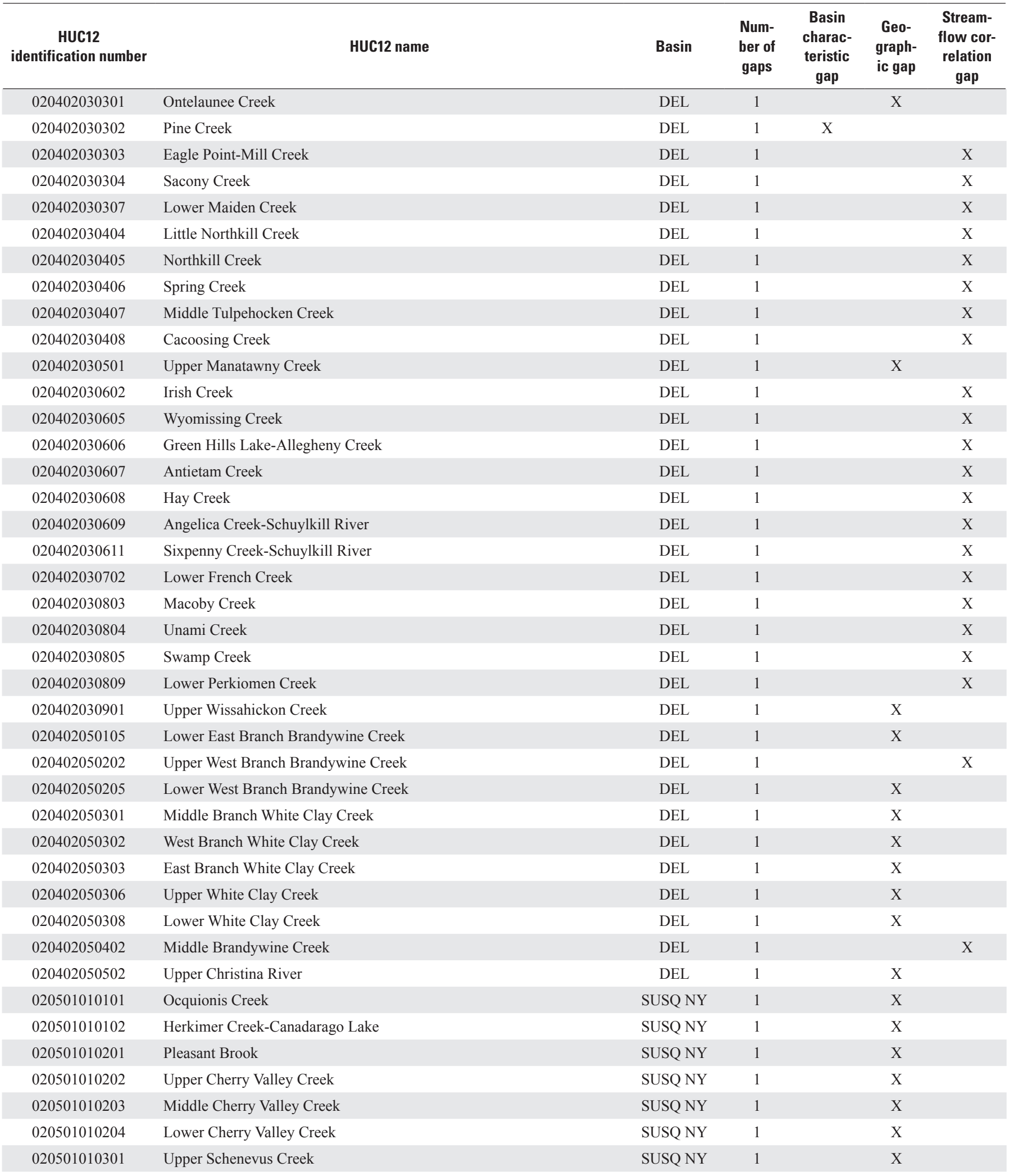


Appendix 5. Complete listing of HUC12 watersheds in Pennsylvania and the Susquehanna River Basin in Pennsylvania and New York with basin characteristic, geographic, or streamflow correlation gaps.-Continued

[HUC12, 12-digit hydrologic unit code; DEL, Delaware River Basin; STLAW, Saint Lawrence River Basin; OHIO, Ohio River Basin; POT, Potomac River Basin; SUSQ, Susquehanna River Basin; SUSQ NY, Susquehanna River Basin watersheds entirely in New York; X, indicates gap]

\begin{tabular}{|c|c|c|c|c|c|c|}
\hline $\begin{array}{c}\text { HUC12 } \\
\text { identification number }\end{array}$ & HUC12 name & Basin & $\begin{array}{c}\text { Num- } \\
\text { ber of } \\
\text { gaps }\end{array}$ & $\begin{array}{l}\text { Basin } \\
\text { charac- } \\
\text { teristic } \\
\text { gap }\end{array}$ & $\begin{array}{l}\text { Geo- } \\
\text { graph- } \\
\text { ic gap }\end{array}$ & $\begin{array}{l}\text { Stream- } \\
\text { flow cor- } \\
\text { relation } \\
\text { gap }\end{array}$ \\
\hline 020501010303 & Middle Schenevus Creek & SUSQ NY & 1 & & $\mathrm{X}$ & \\
\hline 020501010304 & Lower Schenevus Creek & SUSQ NY & 1 & & $\mathrm{X}$ & \\
\hline 020501010401 & Center Brook & SUSQ NY & 1 & & $\mathrm{X}$ & \\
\hline 020501010402 & Middle Brook & SUSQ NY & 1 & & $\mathrm{X}$ & \\
\hline 020501010403 & Upper Charlotte Creek & SUSQ NY & 1 & & $\mathrm{X}$ & \\
\hline 020501010501 & West Branch Otego Creek & SUSQ NY & 1 & & $\mathrm{X}$ & \\
\hline 020501010502 & Upper Otego Creek & SUSQ NY & 1 & & $\mathrm{X}$ & \\
\hline 020501010601 & Cripple Creek & SUSQ NY & 1 & & $\mathrm{X}$ & \\
\hline 020501010602 & Shadow Brook & SUSQ NY & 1 & & $\mathrm{X}$ & \\
\hline 020501010603 & Hayden Creek-Ostego Lake & SUSQ NY & 1 & & $\mathrm{X}$ & \\
\hline 020501010604 & Red Creek-Susquehanna River & SUSQ NY & 1 & & $\mathrm{X}$ & \\
\hline 020501010605 & Goodyear Lake-Susquehanna River & SUSQ NY & 1 & & $\mathrm{X}$ & \\
\hline 020501010606 & Oneonta Creek-Susquehanna River & SUSQ NY & 1 & & $\mathrm{X}$ & \\
\hline 020501010701 & Upper Wharton Creek & SUSQ NY & 1 & & $\mathrm{X}$ & \\
\hline 020501010702 & Middle Wharton Creek & SUSQ NY & 1 & & $\mathrm{X}$ & \\
\hline 020501010703 & Lower Wharton Creek & SUSQ NY & 1 & & $\mathrm{X}$ & \\
\hline 020501010801 & Upper Butternut Creek & SUSQ NY & 1 & & $\mathrm{X}$ & \\
\hline 020501010901 & North Winfield Creek & SUSQ NY & 1 & & $\mathrm{X}$ & \\
\hline 020501010902 & West Branch Unadilla River & SUSQ NY & 1 & & $\mathrm{X}$ & \\
\hline 020501010903 & Headwaters Unadilla River & SUSQ NY & 1 & & $\mathrm{X}$ & \\
\hline 020501011001 & Upper Ouleout Creek & SUSQ NY & 1 & & $\mathrm{X}$ & \\
\hline 020501011002 & Treadwell Creek & SUSQ NY & 1 & & $\mathrm{X}$ & \\
\hline 020501011003 & Middle Ouleout Creek & SUSQ NY & 1 & & $\mathrm{X}$ & \\
\hline 020501011004 & Handsome Brook & SUSQ NY & 1 & & $\mathrm{X}$ & \\
\hline 020501011005 & Lower Ouleout Creek & SUSQ NY & 1 & & $\mathrm{X}$ & \\
\hline 020501011101 & Otsdawa Creek & SUSQ NY & 1 & & $\mathrm{X}$ & \\
\hline 020501011102 & Brier Creek-Susquehanna River & SUSQ NY & 1 & & $\mathrm{X}$ & \\
\hline 020501011103 & Sand Hill Creek-Susquehanna River & SUSQ NY & 1 & & $\mathrm{X}$ & \\
\hline 020501011104 & Carrs Creek & SUSQ NY & 1 & & $\mathrm{X}$ & \\
\hline 020501011105 & Martin Brook-Susquehanna River & SUSQ NY & 1 & & $\mathrm{X}$ & \\
\hline 020501011201 & Bennettsville Creek & SUSQ NY & 1 & & $\mathrm{X}$ & \\
\hline 020501011202 & Kelsey Brook & SUSQ NY & 1 & & $\mathrm{X}$ & \\
\hline 020501011203 & Yaleville Brook-Susquehanna River & SUSQ NY & 1 & & $\mathrm{X}$ & \\
\hline 020501011204 & Wylie Brook & SUSQ NY & 1 & & $\mathrm{X}$ & \\
\hline 020501011205 & Cornell Creek-Susquehanna River & SUSQ NY & 1 & & $\mathrm{X}$ & \\
\hline 020501011206 & Belden Brook-Susquehanna River & SUSQ NY & 1 & & $\mathrm{X}$ & \\
\hline 020501011207 & Ouaquaga Creek-Susquehanna River & SUSQ NY & 1 & & $\mathrm{X}$ & \\
\hline 020501011208 & Occanum Creek-Susquehanna River & SUSQ NY & 1 & & $\mathrm{X}$ & \\
\hline 020501011209 & Cascade Creek-Susquehanna River & SUSQ & 1 & & $\mathrm{X}$ & \\
\hline 020501011307 & Trowbridge Creek & SUSQ & 1 & & $\mathrm{X}$ & \\
\hline 020501011309 & Silver Creek & SUSQ & 1 & & $\mathrm{X}$ & \\
\hline
\end{tabular}


Appendix 5. Complete listing of HUC12 watersheds in Pennsylvania and the Susquehanna River Basin in Pennsylvania and New York with basin characteristic, geographic, or streamflow correlation gaps.-Continued

[HUC12, 12-digit hydrologic unit code; DEL, Delaware River Basin; STLAW, Saint Lawrence River Basin; OHIO, Ohio River Basin; POT, Potomac River Basin; SUSQ, Susquehanna River Basin; SUSQ NY, Susquehanna River Basin watersheds entirely in New York; X, indicates gap]

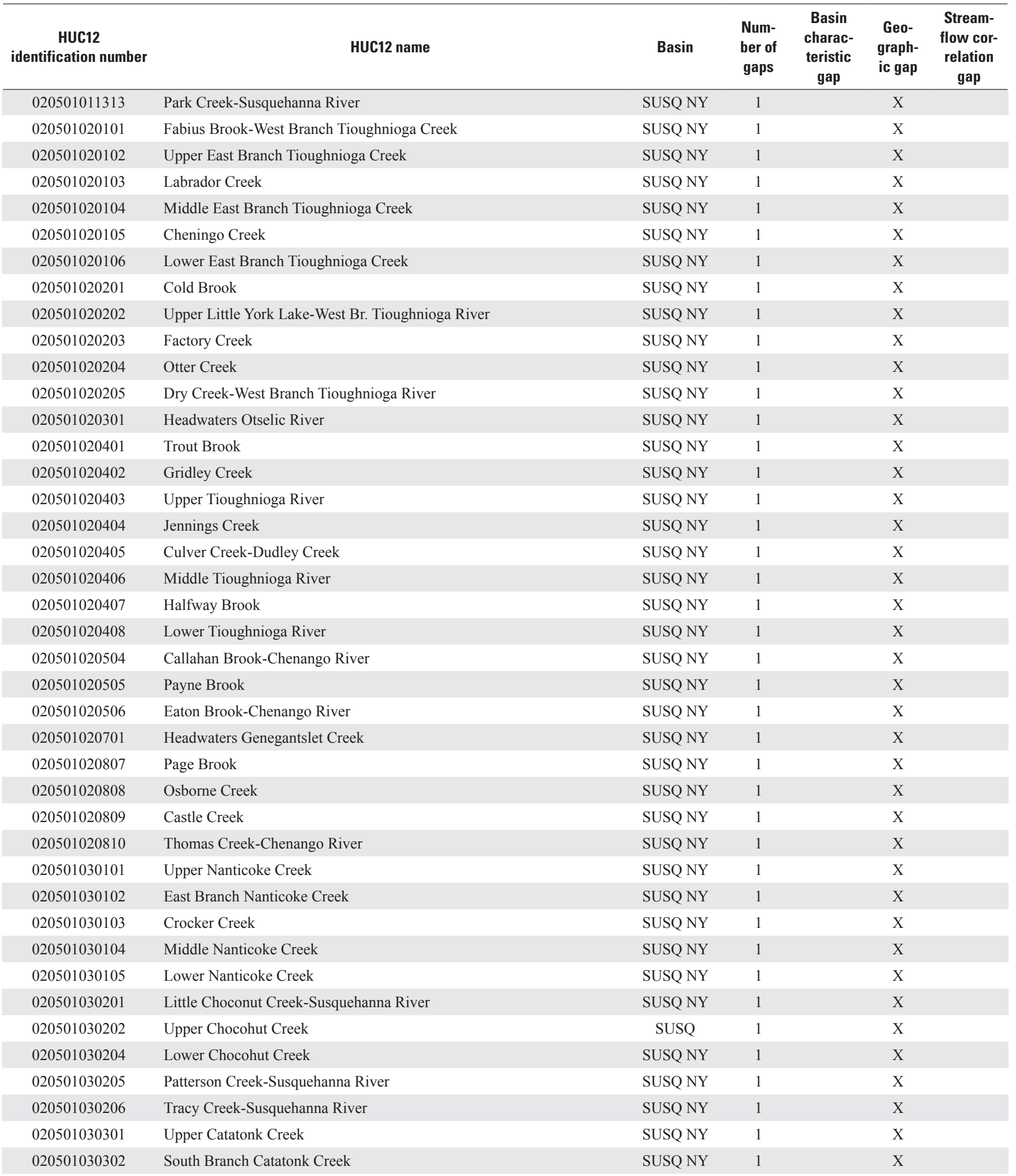


Appendix 5. Complete listing of HUC12 watersheds in Pennsylvania and the Susquehanna River Basin in Pennsylvania and New York with basin characteristic, geographic, or streamflow correlation gaps.-Continued

[HUC12, 12-digit hydrologic unit code; DEL, Delaware River Basin; STLAW, Saint Lawrence River Basin; OHIO, Ohio River Basin; POT, Potomac River Basin; SUSQ, Susquehanna River Basin; SUSQ NY, Susquehanna River Basin watersheds entirely in New York; X, indicates gap]

\begin{tabular}{|c|c|c|c|c|c|c|}
\hline $\begin{array}{c}\text { HUC12 } \\
\text { identification number }\end{array}$ & HUC12 name & Basin & $\begin{array}{c}\text { Num- } \\
\text { ber of } \\
\text { gaps }\end{array}$ & $\begin{array}{c}\text { Basin } \\
\text { charac- } \\
\text { teristic } \\
\text { gap }\end{array}$ & $\begin{array}{l}\text { Geo- } \\
\text { graph- } \\
\text { ic gap }\end{array}$ & $\begin{array}{c}\text { Stream- } \\
\text { flow cor- } \\
\text { relation } \\
\text { gap }\end{array}$ \\
\hline 020501030303 & Willseyville Creek & SUSQ NY & 1 & & $\mathrm{X}$ & \\
\hline 020501030304 & Middle Catatonk Creek & SUSQ NY & 1 & & $\mathrm{X}$ & \\
\hline 020501030305 & Lower Catatonk Creek & SUSQ NY & 1 & & $\mathrm{X}$ & \\
\hline 020501030401 & Headwaters East Branch Owego Creek & SUSQ NY & 1 & & $\mathrm{X}$ & \\
\hline 020501030402 & Upper East Branch Owego Creek & SUSQ NY & 1 & & $\mathrm{X}$ & \\
\hline 020501030403 & Wilson Creek & SUSQ NY & 1 & & $\mathrm{X}$ & \\
\hline 020501030404 & Middle East Branch Owego Creek & SUSQ NY & 1 & & $\mathrm{X}$ & \\
\hline 020501030405 & Upper West Branch Owego Creek & SUSQ NY & 1 & & $\mathrm{X}$ & \\
\hline 020501030406 & Middle West Branch Owego Creek & SUSQ NY & 1 & & $\mathrm{X}$ & \\
\hline 020501030407 & Doolittle Creek & SUSQ NY & 1 & & $\mathrm{X}$ & \\
\hline 020501030408 & Lower West Branch Owego Creek & SUSQ NY & 1 & & $\mathrm{X}$ & \\
\hline 020501030409 & Lower East Branch Owego Creek-Owego Creek & SUSQ NY & 1 & & $\mathrm{X}$ & \\
\hline 020501030502 & Little Nanticoke Creek & SUSQ NY & 1 & & $\mathrm{X}$ & \\
\hline 020501030503 & Pumpelly Creek-Susquehanna River & SUSQ NY & 1 & & $\mathrm{X}$ & \\
\hline 020501030504 & Chambers Creek-Pipe Creek & SUSQ NY & 1 & & $\mathrm{X}$ & \\
\hline 020501030505 & Hunts Creek-Susquehanna River & SUSQ NY & 1 & & $\mathrm{X}$ & \\
\hline 020501030601 & Pony Hollow Creek & SUSQ NY & 1 & & $\mathrm{X}$ & \\
\hline 020501030602 & Headwaters Cayuta Creek & SUSQ NY & 1 & & $\mathrm{X}$ & \\
\hline 020501030603 & Upper Cayuta Creek & SUSQ NY & 1 & & $\mathrm{X}$ & \\
\hline 020501030604 & Middle Cayuta Creek & SUSQ NY & 1 & & $\mathrm{X}$ & \\
\hline 020501030705 & Ellis Creek & SUSQ NY & 1 & & $\mathrm{X}$ & \\
\hline 020501040101 & McHenry Valley Creek & SUSQ NY & 1 & & $\mathrm{X}$ & \\
\hline 020501040102 & Karr Valley Creek & SUSQ NY & 1 & & $\mathrm{X}$ & \\
\hline 020501040103 & Upper Canacadea Creek & SUSQ NY & 1 & & $\mathrm{X}$ & \\
\hline 020501040104 & Lower Canacadea Creek & SUSQ NY & 1 & & $\mathrm{X}$ & \\
\hline 020501040401 & Lime Kiln Creek & SUSQ NY & 1 & & $\mathrm{X}$ & \\
\hline 020501040402 & Headwaters Canisteo River & SUSQ NY & 1 & & $\mathrm{X}$ & \\
\hline 020501040403 & Seeley Creek & SUSQ NY & 1 & & $\mathrm{X}$ & \\
\hline 020501040404 & Big Creek & SUSQ NY & 1 & & $\mathrm{X}$ & \\
\hline 020501040406 & Upper Canisteo River & SUSQ NY & 1 & $\mathrm{X}$ & & \\
\hline 020501040408 & Middle Canisteo River & SUSQ NY & 1 & $\mathrm{X}$ & & \\
\hline 020501040409 & Tracy Creek & SUSQ NY & 1 & $\mathrm{X}$ & & \\
\hline 020501040410 & Goodhue Creek & SUSQ NY & 1 & $\mathrm{X}$ & & \\
\hline 020501040411 & Lower Canisteo River & SUSQ NY & 1 & $\mathrm{X}$ & & \\
\hline 020501040602 & Norris Brook & SUSQ & 1 & & & $\mathrm{X}$ \\
\hline 020501040603 & Losey Creek & SUSQ & 1 & & $\mathrm{X}$ & \\
\hline 020501040703 & Painter Run-Mill Creek & SUSQ & 1 & & & $\mathrm{X}$ \\
\hline 020501040801 & Headwaters Cowanesque River & SUSQ & 1 & & $\mathrm{X}$ & \\
\hline 020501040804 & Jemison Creek & SUSQ & 1 & $\mathrm{X}$ & & \\
\hline 020501040806 & Holden Creek & SUSQ & 1 & $\mathrm{X}$ & & \\
\hline 020501040808 & MIddle Cowanesque River & SUSQ & 1 & $\mathrm{X}$ & & \\
\hline
\end{tabular}


Appendix 5. Complete listing of HUC12 watersheds in Pennsylvania and the Susquehanna River Basin in Pennsylvania and New York with basin characteristic, geographic, or streamflow correlation gaps.-Continued

[HUC12, 12-digit hydrologic unit code; DEL, Delaware River Basin; STLAW, Saint Lawrence River Basin; OHIO, Ohio River Basin; POT, Potomac River Basin; SUSQ, Susquehanna River Basin; SUSQ NY, Susquehanna River Basin watersheds entirely in New York; X, indicates gap]

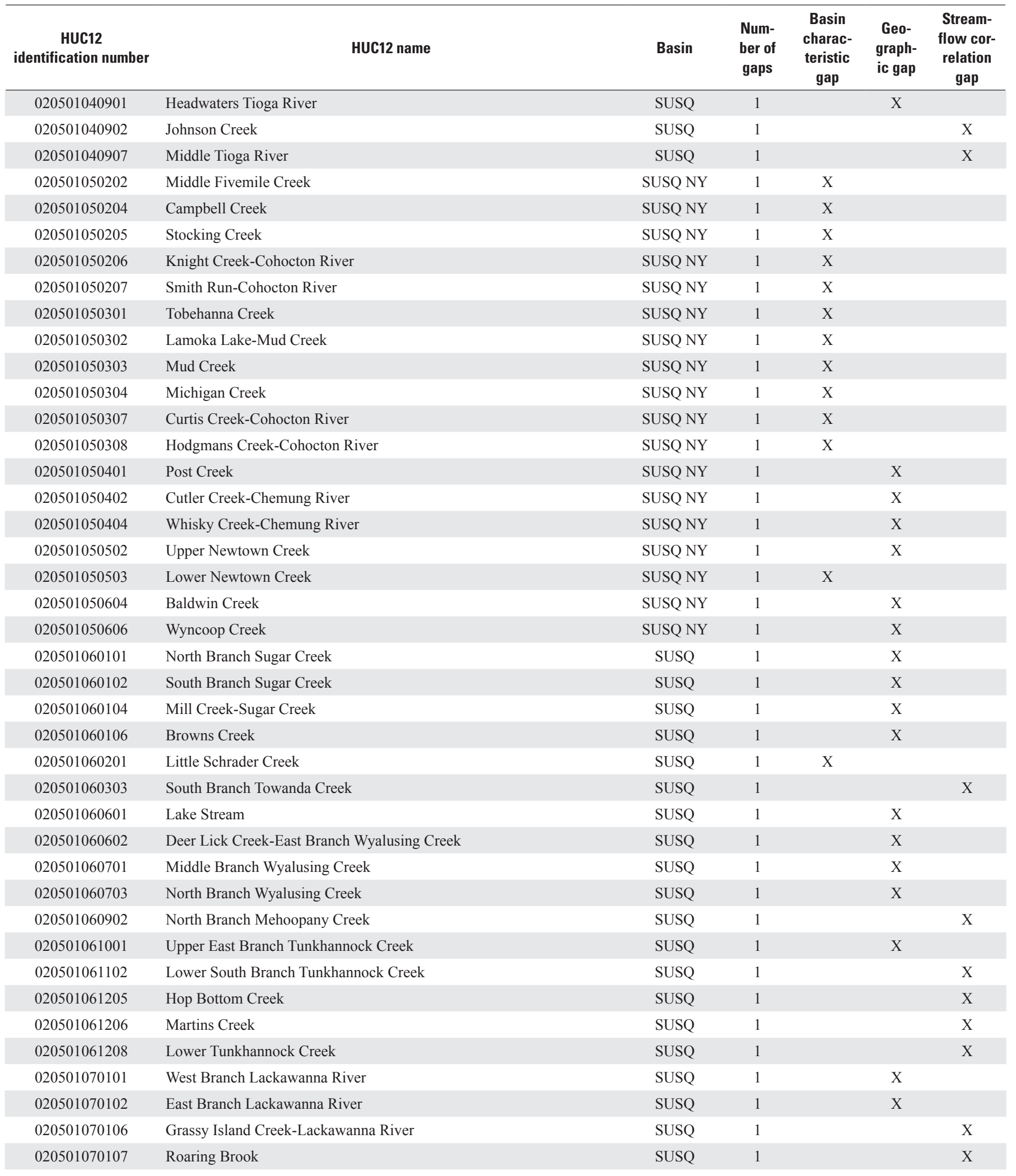


Appendix 5. Complete listing of HUC12 watersheds in Pennsylvania and the Susquehanna River Basin in Pennsylvania and New York with basin characteristic, geographic, or streamflow correlation gaps.-Continued

[HUC12, 12-digit hydrologic unit code; DEL, Delaware River Basin; STLAW, Saint Lawrence River Basin; OHIO, Ohio River Basin; POT, Potomac River Basin; SUSQ, Susquehanna River Basin; SUSQ NY, Susquehanna River Basin watersheds entirely in New York; X, indicates gap]

\begin{tabular}{|c|c|c|c|c|c|c|}
\hline $\begin{array}{c}\text { HUC12 } \\
\text { identification number }\end{array}$ & HUC12 name & Basin & $\begin{array}{c}\text { Num- } \\
\text { ber of } \\
\text { gaps }\end{array}$ & $\begin{array}{l}\text { Basin } \\
\text { charac- } \\
\text { teristic } \\
\text { gap }\end{array}$ & $\begin{array}{l}\text { Geo- } \\
\text { graph- } \\
\text { ic gap }\end{array}$ & $\begin{array}{l}\text { Stream- } \\
\text { flow cor- } \\
\text { relation } \\
\text { gap }\end{array}$ \\
\hline 020501070108 & Spring Brook & SUSQ & 1 & & & $\mathrm{X}$ \\
\hline 020501070109 & City of Scranton-Lackawanna River & SUSQ & 1 & & & $\mathrm{X}$ \\
\hline 020501070110 & Lackawanna River-Susquehanna River & SUSQ & 1 & & & $\mathrm{X}$ \\
\hline 020501070204 & Sugar Notch Run-Solomon Creek & SUSQ & 1 & & & $\mathrm{X}$ \\
\hline 020501070206 & Nanticoke Creek & SUSQ & 1 & & $\mathrm{X}$ & \\
\hline 020501070304 & Little Wapwallopen Creek & SUSQ & 1 & & $\mathrm{X}$ & \\
\hline 020501070306 & Wapwallopen Creek & SUSQ & 1 & & & $\mathrm{X}$ \\
\hline 020501070504 & Huntington Creek-Fishing Creek & SUSQ & 1 & & & $\mathrm{X}$ \\
\hline 020501070601 & Kline Hollow Run-Little Fishing Creek & SUSQ & 1 & & & $\mathrm{X}$ \\
\hline 020501070602 & Little Fishing Creek-Fishing Creek & SUSQ & 1 & & & $\mathrm{X}$ \\
\hline 020501070705 & Mud Run-Green Creek & SUSQ & 1 & & & $\mathrm{X}$ \\
\hline 020501070706 & Hemlock Creek & SUSQ & 1 & & & $\mathrm{X}$ \\
\hline 020501070707 & Fishing Creek-Susquehanna River & SUSQ & 1 & & & $\mathrm{X}$ \\
\hline 020502010101 & Upper Chest Creek & SUSQ & 1 & & & $\mathrm{X}$ \\
\hline 020502010102 & Middle Chest Creek & SUSQ & 1 & & & $\mathrm{X}$ \\
\hline 020502010301 & Headwaters Clearfield Creek & SUSQ & 1 & & $\mathrm{X}$ & \\
\hline 020502010305 & South Witmer Run-North Witmer Run & SUSQ & 1 & & & $\mathrm{X}$ \\
\hline 020502010306 & Muddy Run & SUSQ & 1 & & & $\mathrm{X}$ \\
\hline 020502010307 & Middle Clearfield Creek & SUSQ & 1 & & & $\mathrm{X}$ \\
\hline 020502010308 & Lower Clearfield Creek & SUSQ & 1 & & & $\mathrm{X}$ \\
\hline 020502010309 & Little Clearfield Creek & SUSQ & 1 & & & $\mathrm{X}$ \\
\hline 020502010310 & Morgan Run-Lower Clearfield Creek & SUSQ & 1 & & & $\mathrm{X}$ \\
\hline 020502010403 & Beaver Run-West Branch Susquehanna River & SUSQ & 1 & & $\mathrm{X}$ & \\
\hline 020502010404 & Bear Run & SUSQ & 1 & & & $\mathrm{X}$ \\
\hline 020502010405 & Bell Run & SUSQ & 1 & & & $\mathrm{X}$ \\
\hline 020502010406 & Deer Run-West Branch Susquehanna River & SUSQ & 1 & & & $\mathrm{X}$ \\
\hline 020502010501 & Beaver Run & SUSQ & 1 & & & $\mathrm{X}$ \\
\hline 020502010502 & Upper Moshannon Creek & SUSQ & 1 & & $\mathrm{X}$ & \\
\hline 020502010503 & Laurel Run & SUSQ & 1 & & & $\mathrm{X}$ \\
\hline 020502010504 & Cold Stream & SUSQ & 1 & $\mathrm{X}$ & & \\
\hline 020502010506 & Middle Moshannon Creek & SUSQ & 1 & & & $\mathrm{X}$ \\
\hline 020502010508 & Lower Moshannon Creek & SUSQ & 1 & & & $\mathrm{X}$ \\
\hline 020502010601 & Headwaters Mosquito Creek & SUSQ & 1 & & $\mathrm{X}$ & \\
\hline 020502010703 & Moravian Run & SUSQ & 1 & & $\mathrm{X}$ & \\
\hline 020502010707 & Millstone Run-West Branch Susquehanna River & SUSQ & 1 & & $\mathrm{X}$ & \\
\hline 020502020101 & Cowley Run & SUSQ & 1 & $\mathrm{X}$ & & \\
\hline 020502020102 & Sinnemahoning Portage Creek-Driftwood Branch Sinnemahoning Creek & SUSQ & 1 & $\mathrm{X}$ & & \\
\hline 020502020204 & West Creek & SUSQ & 1 & & & $\mathrm{X}$ \\
\hline 020502020205 & Hunts Run & SUSQ & 1 & $\mathrm{X}$ & & \\
\hline 020502020207 & Driftwood Branch Sinnemahoning Creek-Sinnemahoning Creek & SUSQ & 1 & $\mathrm{X}$ & & \\
\hline 020502020401 & Big Moores Run & SUSQ & 1 & & $\mathrm{X}$ & \\
\hline
\end{tabular}


Appendix 5. Complete listing of HUC12 watersheds in Pennsylvania and the Susquehanna River Basin in Pennsylvania and New York with basin characteristic, geographic, or streamflow correlation gaps.-Continued

[HUC12, 12-digit hydrologic unit code; DEL, Delaware River Basin; STLAW, Saint Lawrence River Basin; OHIO, Ohio River Basin; POT, Potomac River Basin; SUSQ, Susquehanna River Basin; SUSQ NY, Susquehanna River Basin watersheds entirely in New York; X, indicates gap]

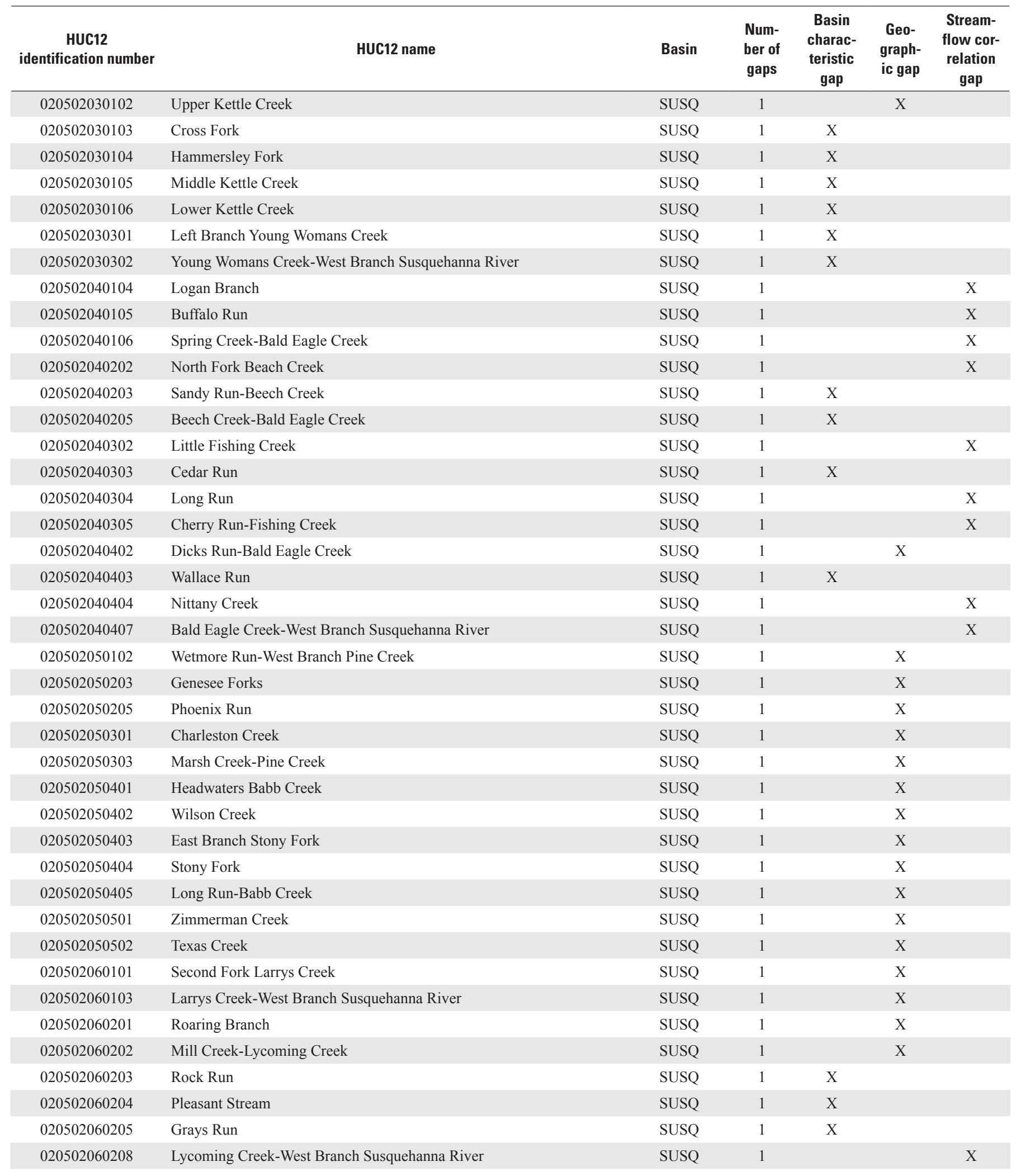


Appendix 5. Complete listing of HUC12 watersheds in Pennsylvania and the Susquehanna River Basin in Pennsylvania and New York with basin characteristic, geographic, or streamflow correlation gaps.-Continued

[HUC12, 12-digit hydrologic unit code; DEL, Delaware River Basin; STLAW, Saint Lawrence River Basin; OHIO, Ohio River Basin; POT, Potomac River Basin; SUSQ, Susquehanna River Basin; SUSQ NY, Susquehanna River Basin watersheds entirely in New York; X, indicates gap]

\begin{tabular}{|c|c|c|c|c|c|c|}
\hline $\begin{array}{c}\text { HUC12 } \\
\text { identification number }\end{array}$ & HUC12 name & Basin & $\begin{array}{l}\text { Num- } \\
\text { ber of } \\
\text { gaps }\end{array}$ & $\begin{array}{c}\text { Basin } \\
\text { charac- } \\
\text { teristic } \\
\text { gap }\end{array}$ & $\begin{array}{l}\text { Geo- } \\
\text { graph- } \\
\text { ic gap }\end{array}$ & $\begin{array}{l}\text { Stream- } \\
\text { flow cor- } \\
\text { relation } \\
\text { gap }\end{array}$ \\
\hline 020502060401 & Lick Creek & SUSQ & 1 & & $\mathrm{X}$ & \\
\hline 020502060501 & Porter Creek-Hoagland Branch & SUSQ & 1 & & & $\mathrm{X}$ \\
\hline 020502060502 & Elk Creek & SUSQ & 1 & & & $\mathrm{X}$ \\
\hline 020502060504 & Plunketts Creek & SUSQ & 1 & $\mathrm{X}$ & & \\
\hline 020502060505 & Bear Creek & SUSQ & 1 & $\mathrm{X}$ & & \\
\hline 020502060507 & Mill Creek-East Side of Loyalsock Creek & SUSQ & 1 & & & $\mathrm{X}$ \\
\hline 020502060508 & Mill Creek-West Side of Loyalsock Creek & SUSQ & 1 & & & $\mathrm{X}$ \\
\hline 020502060509 & Little Bear Creek-Loyalsock Creek & SUSQ & 1 & & & $\mathrm{X}$ \\
\hline 020502060601 & Antes Creek & SUSQ & 1 & & $\mathrm{X}$ & \\
\hline 020502060602 & Quenshukeny Run & SUSQ & 1 & & $\mathrm{X}$ & \\
\hline 020502060605 & Wolf Run & SUSQ & 1 & & $\mathrm{X}$ & \\
\hline 020502060802 & Rock Run-Muncy Creek & SUSQ & 1 & & & $\mathrm{X}$ \\
\hline 020502060902 & White Deer Hole Creek-West Branch Susquehanna River & SUSQ & 1 & & $\mathrm{X}$ & \\
\hline 020502061001 & North Branch Buffalo Creek & SUSQ & 1 & & $\mathrm{X}$ & \\
\hline 020502061002 & Rapid Run & SUSQ & 1 & & $\mathrm{X}$ & \\
\hline 020502061003 & Spruce Run & SUSQ & 1 & & $\mathrm{X}$ & \\
\hline 020503010102 & Carbon Run-Shamokin Creek & SUSQ & 1 & & & $\mathrm{X}$ \\
\hline 020503010104 & Shamokin Creek-Susquehanna River & SUSQ & 1 & & & $\mathrm{X}$ \\
\hline 020503010201 & Elk Creek & SUSQ & 1 & & & $\mathrm{X}$ \\
\hline 020503010202 & Voneida Run-Pine Creek & SUSQ & 1 & & & $\mathrm{X}$ \\
\hline 020503010403 & Upper Penns Creek & SUSQ & 1 & $\mathrm{X}$ & & \\
\hline 020503010404 & Laurel Run & SUSQ & 1 & & & $\mathrm{X}$ \\
\hline 020503010405 & Middle Penns Creek & SUSQ & 1 & & & $\mathrm{X}$ \\
\hline 020503010406 & Lower Penns Creek-Susquehanna River & SUSQ & 1 & & & $\mathrm{X}$ \\
\hline 020503010501 & Upper Mahanoy Creek & SUSQ & 1 & & $\mathrm{X}$ & \\
\hline 020503010702 & Rausch Creek-Pine Creek & SUSQ & 1 & & $\mathrm{X}$ & \\
\hline 020503010802 & Lower Mahantango Creek & SUSQ & 1 & & & $\mathrm{X}$ \\
\hline 020503020102 & South Poplar Run-Frankstown Branch Juniata River & SUSQ & 1 & & $\mathrm{X}$ & \\
\hline 020503020103 & Plum Creek & SUSQ & 1 & & $\mathrm{X}$ & \\
\hline 020503020104 & Halter Creek & SUSQ & 1 & & $\mathrm{X}$ & \\
\hline 020503020201 & Blair Gap Run & SUSQ & 1 & & & $\mathrm{X}$ \\
\hline 020503020202 & Mill Run-Beaverdam Branch & SUSQ & 1 & & & $\mathrm{X}$ \\
\hline 020503020301 & Canoe Creek & SUSQ & 1 & & & $\mathrm{X}$ \\
\hline 020503020303 & Piney Creek & SUSQ & 1 & $\mathrm{X}$ & & \\
\hline 020503020304 & Clover Creek & SUSQ & 1 & & $\mathrm{X}$ & \\
\hline 020503020403 & Warriors Mark Run & SUSQ & 1 & & $\mathrm{X}$ & \\
\hline 020503020503 & Tipton Run & SUSQ & 1 & $\mathrm{X}$ & & \\
\hline 020503020703 & East Branch Standing Stone Creek & SUSQ & 1 & & & $\mathrm{X}$ \\
\hline 020503020704 & Lower Standing Stone Creek & SUSQ & 1 & & & $\mathrm{X}$ \\
\hline 020503020801 & Juniata River-City of Huntingdon & SUSQ & 1 & & $\mathrm{X}$ & \\
\hline 020503020802 & Snyders Run-Juniata River & SUSQ & 1 & & $\mathrm{X}$ & \\
\hline
\end{tabular}


Appendix 5. Complete listing of HUC12 watersheds in Pennsylvania and the Susquehanna River Basin in Pennsylvania and New York with basin characteristic, geographic, or streamflow correlation gaps.-Continued

[HUC12, 12-digit hydrologic unit code; DEL, Delaware River Basin; STLAW, Saint Lawrence River Basin; OHIO, Ohio River Basin; POT, Potomac River Basin; SUSQ, Susquehanna River Basin; SUSQ NY, Susquehanna River Basin watersheds entirely in New York; X, indicates gap]

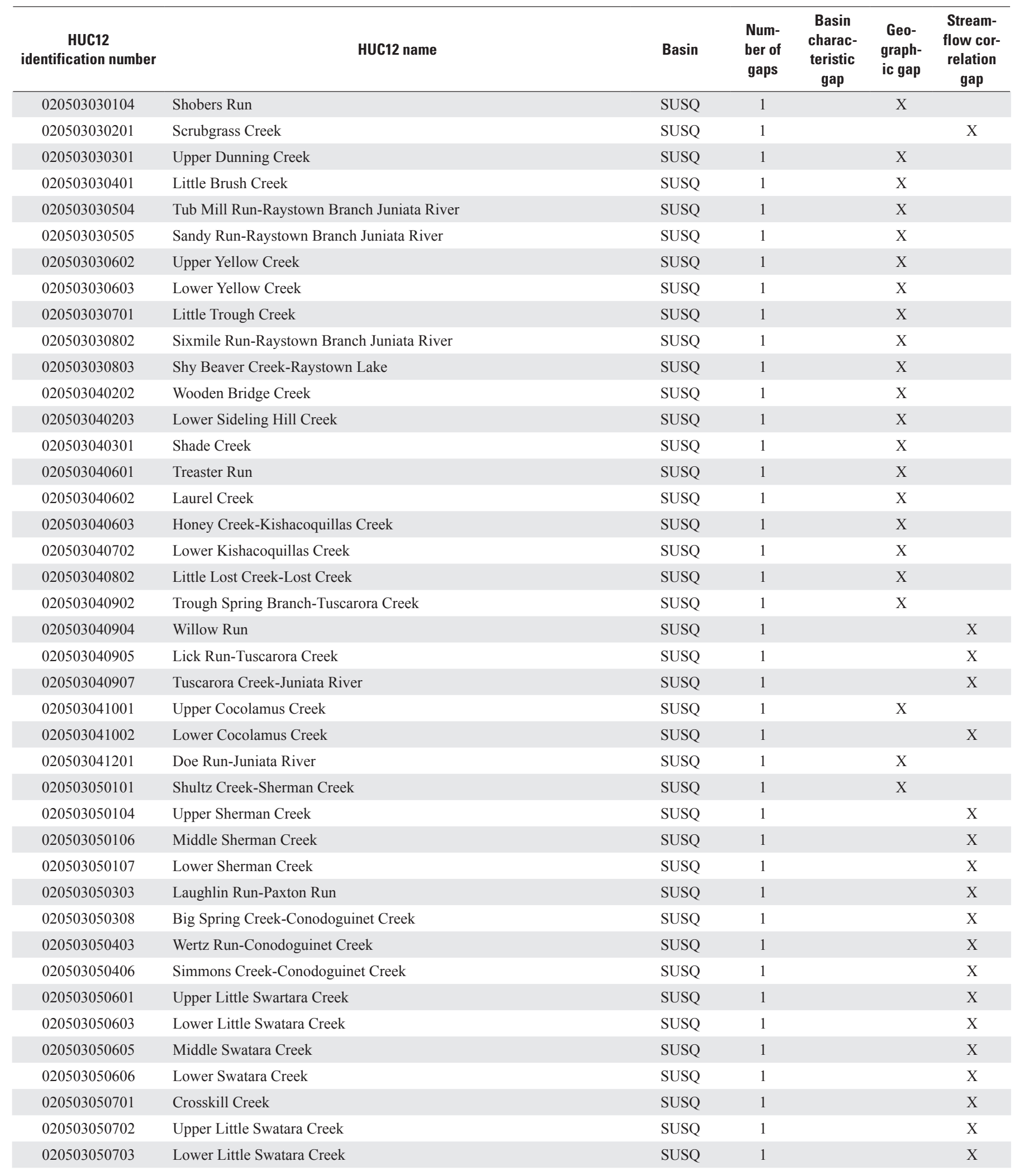


Appendix 5. Complete listing of HUC12 watersheds in Pennsylvania and the Susquehanna River Basin in Pennsylvania and New York with basin characteristic, geographic, or streamflow correlation gaps.-Continued

[HUC12, 12-digit hydrologic unit code; DEL, Delaware River Basin; STLAW, Saint Lawrence River Basin; OHIO, Ohio River Basin; POT, Potomac River Basin; SUSQ, Susquehanna River Basin; SUSQ NY, Susquehanna River Basin watersheds entirely in New York; X, indicates gap]

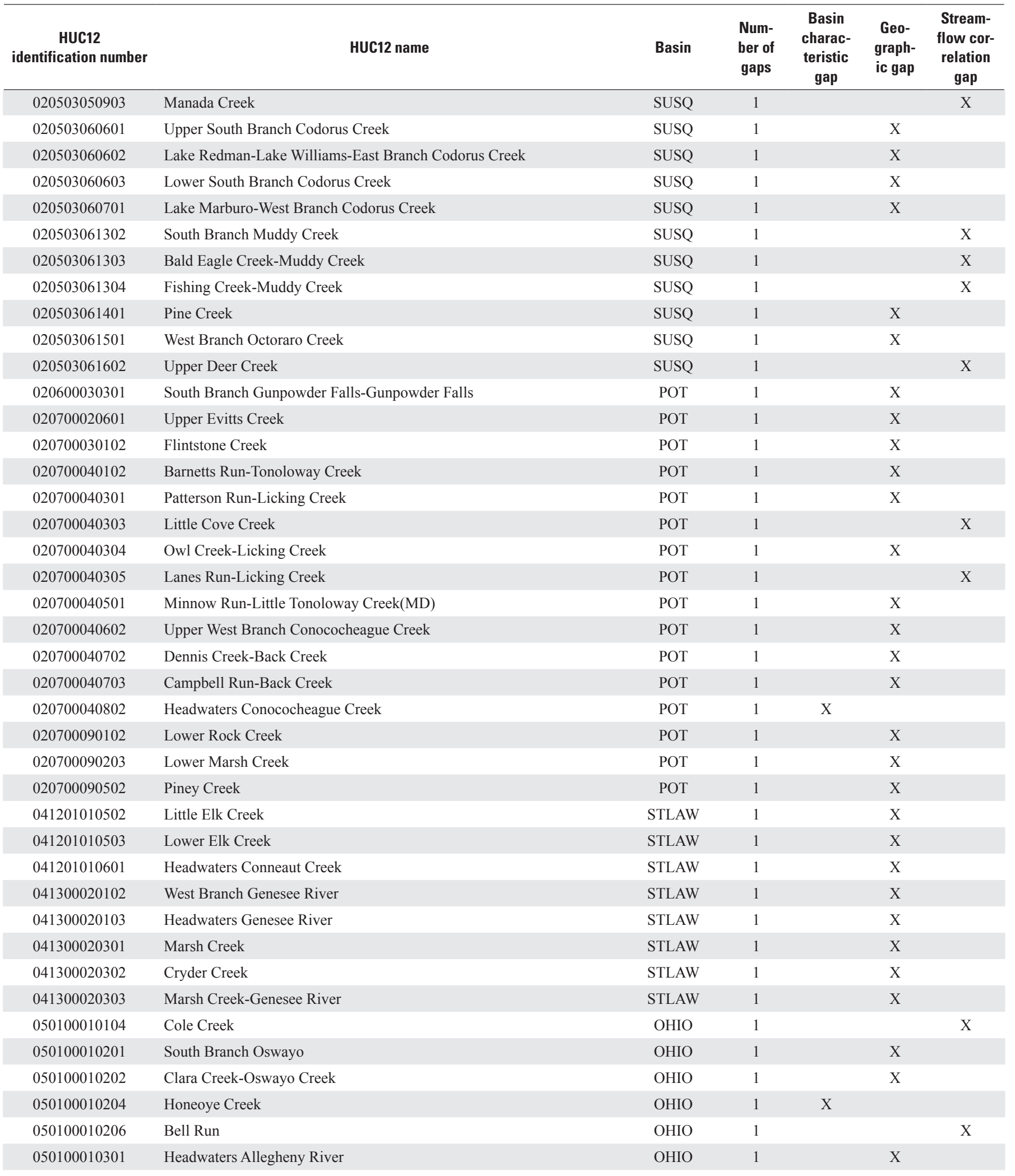


Appendix 5. Complete listing of HUC12 watersheds in Pennsylvania and the Susquehanna River Basin in Pennsylvania and New York with basin characteristic, geographic, or streamflow correlation gaps.-Continued

[HUC12, 12-digit hydrologic unit code; DEL, Delaware River Basin; STLAW, Saint Lawrence River Basin; OHIO, Ohio River Basin; POT, Potomac River Basin; SUSQ, Susquehanna River Basin; SUSQ NY, Susquehanna River Basin watersheds entirely in New York; X, indicates gap]

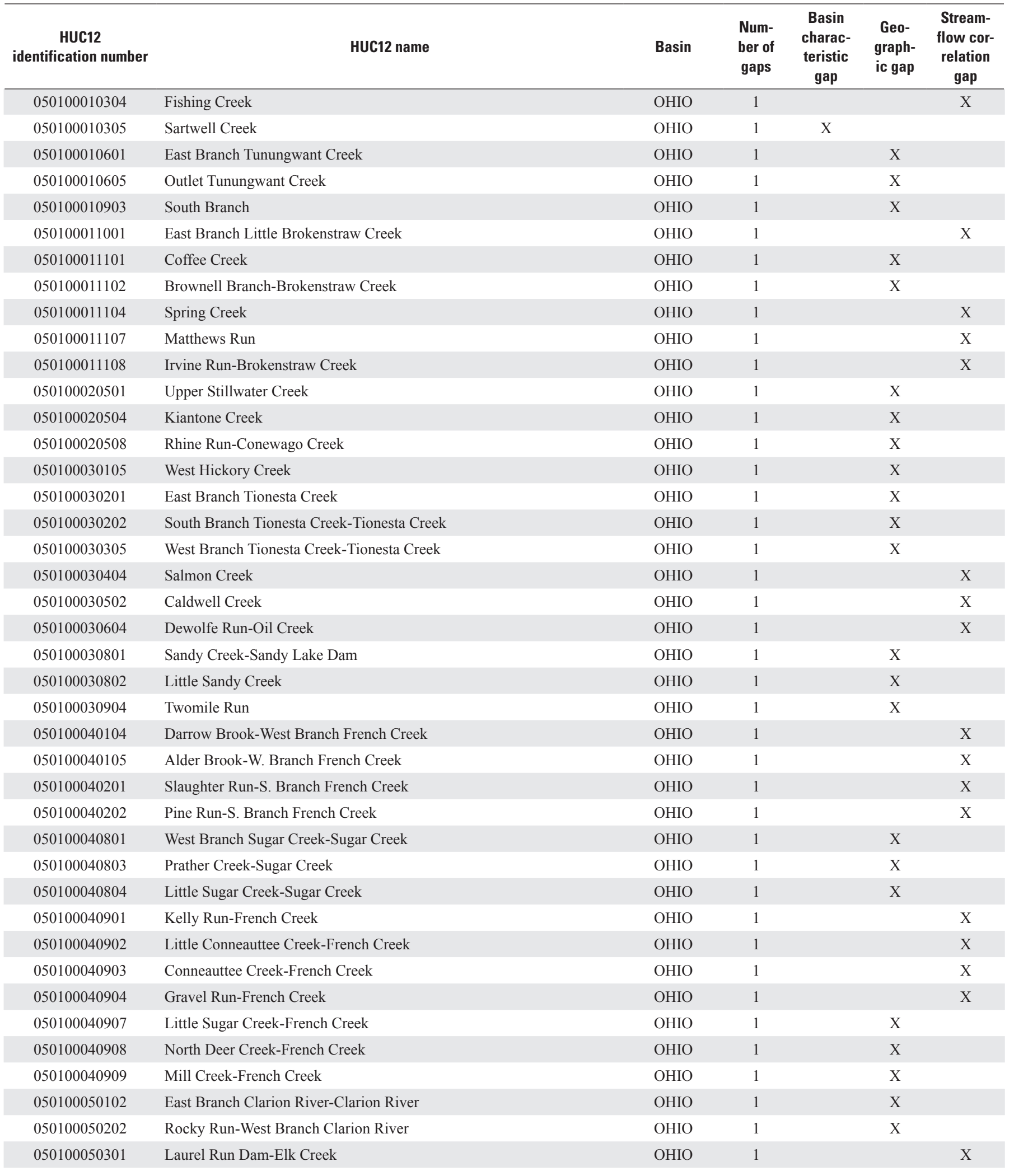


Appendix 5. Complete listing of HUC12 watersheds in Pennsylvania and the Susquehanna River Basin in Pennsylvania and New York with basin characteristic, geographic, or streamflow correlation gaps.-Continued

[HUC12, 12-digit hydrologic unit code; DEL, Delaware River Basin; STLAW, Saint Lawrence River Basin; OHIO, Ohio River Basin; POT, Potomac River Basin; SUSQ, Susquehanna River Basin; SUSQ NY, Susquehanna River Basin watersheds entirely in New York; X, indicates gap]

\begin{tabular}{|c|c|c|c|c|c|c|}
\hline $\begin{array}{c}\text { HUC12 } \\
\text { identification number }\end{array}$ & HUC12 name & Basin & $\begin{array}{c}\text { Num- } \\
\text { ber of } \\
\text { gaps }\end{array}$ & $\begin{array}{c}\text { Basin } \\
\text { charac- } \\
\text { teristic } \\
\text { gap }\end{array}$ & $\begin{array}{c}\text { Geo- } \\
\text { graph- } \\
\text { ic gap }\end{array}$ & $\begin{array}{l}\text { Stream- } \\
\text { flow cor- } \\
\text { relation } \\
\text { gap }\end{array}$ \\
\hline 050100050501 & East Branch Spring Creek & OHIO & 1 & & $\mathrm{X}$ & \\
\hline 050100050603 & Bear Creek & OHIO & 1 & $\mathrm{X}$ & & \\
\hline 050100050606 & West Branch Millstone Creek & OHIO & 1 & & $\mathrm{X}$ & \\
\hline 050100050704 & Blyson Run-Clarion River & OHIO & 1 & & & $\mathrm{X}$ \\
\hline 050100060302 & Wolf Run & OHIO & 1 & & $\mathrm{X}$ & \\
\hline 050100060401 & Big Run & OHIO & 1 & & & $\mathrm{X}$ \\
\hline 050100060704 & Canoe Creek & $\mathrm{OHIO}$ & 1 & & & $\mathrm{X}$ \\
\hline 050100060707 & Mahoning Creek Lake-Mahoning Creek & OHIO & 1 & & & $\mathrm{X}$ \\
\hline 050100060901 & South Branch Plum Creek & $\mathrm{OHIO}$ & 1 & $\mathrm{X}$ & & \\
\hline 050100060902 & Keystone Lake-North Branch Plum Creek & OHIO & 1 & $\mathrm{X}$ & & \\
\hline 050100061002 & McKee Run-Crooked Creek & $\mathrm{OHIO}$ & 1 & $\mathrm{X}$ & & \\
\hline 050100061004 & Cherry Run & OHIO & 1 & & & $\mathrm{X}$ \\
\hline 050100061005 & Crooked Creek-Allegheny River & OHIO & 1 & & & $\mathrm{X}$ \\
\hline 050100070201 & Dark Shade Creek & $\mathrm{OHIO}$ & 1 & & $\mathrm{X}$ & \\
\hline 050100070301 & Indian Lake-Lake Stonycreek-Rhoads Creek & OHIO & 1 & & $\mathrm{X}$ & \\
\hline 050100070302 & Headwaters Stonycreek River & OHIO & 1 & & $\mathrm{X}$ & \\
\hline 050100070602 & North Branch Blacklick Creek-Backlick Creek & $\mathrm{OHIO}$ & 1 & & $\mathrm{X}$ & \\
\hline 050100070801 & South Branch Two Lick Creek & $\mathrm{OHIO}$ & 1 & & & $\mathrm{X}$ \\
\hline 050100070802 & North Branch Two Lick Creek & OHIO & 1 & & & $\mathrm{X}$ \\
\hline 050100070803 & Cherry Run & OHIO & 1 & & & $\mathrm{X}$ \\
\hline 050100070804 & Two Lick Creek-Blacklick Creek & OHIO & 1 & & & $\mathrm{X}$ \\
\hline 050100070901 & South Branch Blacklick Creek & OHIO & 1 & & & $\mathrm{X}$ \\
\hline 050100070902 & Mardis Creek-Blacklick Creek & $\mathrm{OHIO}$ & 1 & & & $\mathrm{X}$ \\
\hline 050100070903 & Brush Creek & $\mathrm{OHIO}$ & 1 & & & $\mathrm{X}$ \\
\hline 050100070904 & Backlick Creek-Conemaugh River & OHIO & 1 & & & $\mathrm{X}$ \\
\hline 050100071003 & Hendricks Creek & OHIO & 1 & & $\mathrm{X}$ & \\
\hline 050100071004 & Tubmill Creek & OHIO & 1 & & $\mathrm{X}$ & \\
\hline 050100080203 & Beaver Run Reservoir-Beaver Run & $\mathrm{OHIO}$ & 1 & & $\mathrm{X}$ & \\
\hline 050100090101 & Patterson Creek & $\mathrm{OHIO}$ & 1 & & & $\mathrm{X}$ \\
\hline
\end{tabular}


Appendix 5. Complete listing of HUC12 watersheds in Pennsylvania and the Susquehanna River Basin in Pennsylvania and New York with basin characteristic, geographic, or streamflow correlation gaps.-Continued

[HUC12, 12-digit hydrologic unit code; DEL, Delaware River Basin; STLAW, Saint Lawrence River Basin; OHIO, Ohio River Basin; POT, Potomac River Basin; SUSQ, Susquehanna River Basin; SUSQ NY, Susquehanna River Basin watersheds entirely in New York; X, indicates gap]

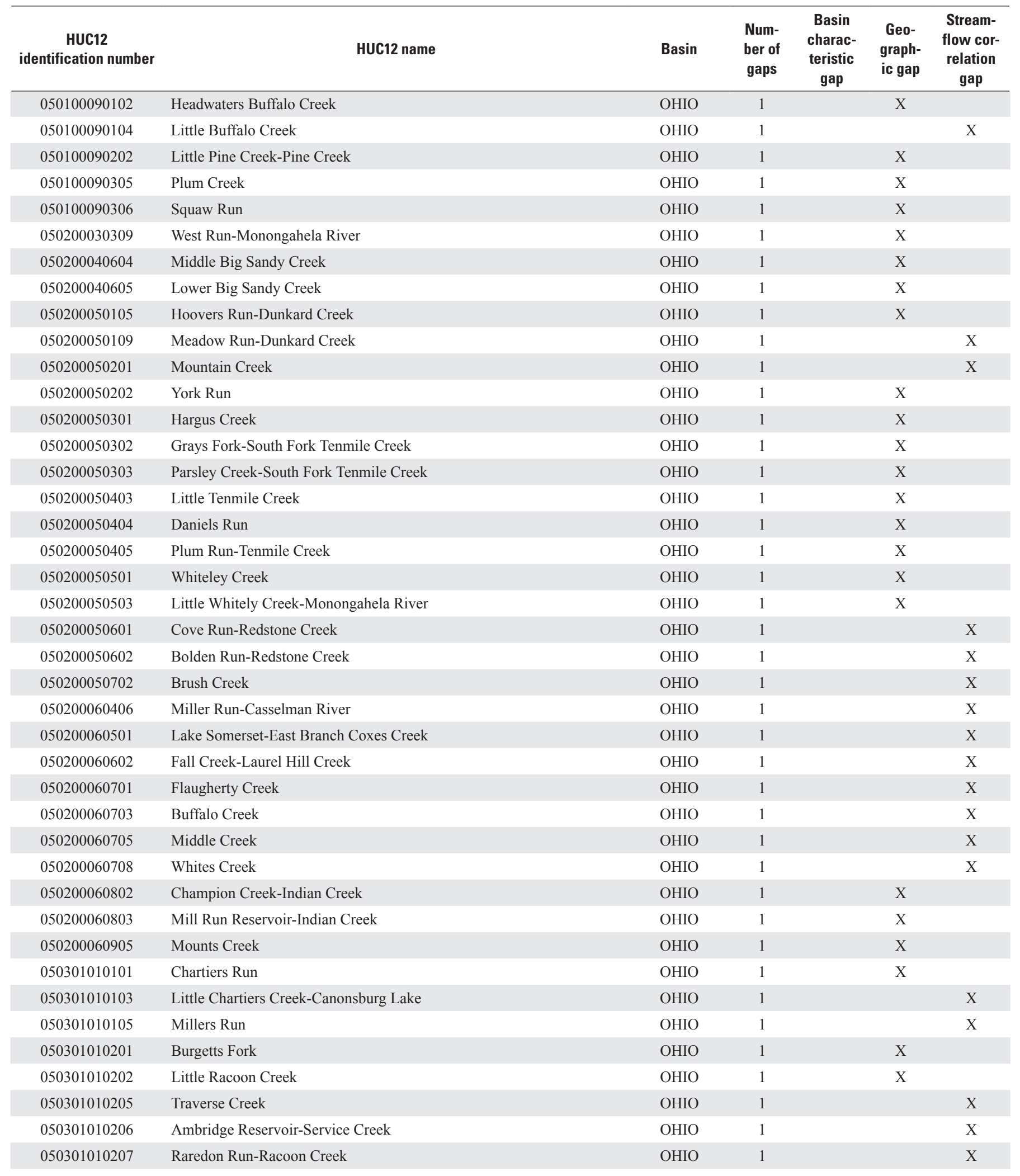


Appendix 5. Complete listing of HUC12 watersheds in Pennsylvania and the Susquehanna River Basin in Pennsylvania and New York with basin characteristic, geographic, or streamflow correlation gaps.-Continued

[HUC12, 12-digit hydrologic unit code; DEL, Delaware River Basin; STLAW, Saint Lawrence River Basin; OHIO, Ohio River Basin; POT, Potomac River Basin; SUSQ, Susquehanna River Basin; SUSQ NY, Susquehanna River Basin watersheds entirely in New York; X, indicates gap]

\begin{tabular}{|c|c|c|c|c|c|c|}
\hline $\begin{array}{c}\text { HUC12 } \\
\text { identification number }\end{array}$ & HUC12 name & Basin & $\begin{array}{l}\text { Num- } \\
\text { ber of } \\
\text { gaps }\end{array}$ & $\begin{array}{c}\text { Basin } \\
\text { charac- } \\
\text { teristic } \\
\text { gap }\end{array}$ & $\begin{array}{l}\text { Geo- } \\
\text { graph- } \\
\text { ic gap }\end{array}$ & $\begin{array}{l}\text { Stream- } \\
\text { flow cor- } \\
\text { relation } \\
\text { gap }\end{array}$ \\
\hline 050301010308 & Big Sewickley Creek & OHIO & 1 & & & $\mathrm{X}$ \\
\hline 050301010606 & Leslie Run-Bull Creek & $\mathrm{OHIO}$ & 1 & & $\mathrm{X}$ & \\
\hline 050301020102 & Linesville Creek-Frontal Pymatuning Reservoir & OHIO & 1 & & & $\mathrm{X}$ \\
\hline 050301020201 & Upper Little Shenango River & OHIO & 1 & & $\mathrm{X}$ & \\
\hline 050301020304 & Booth Run-Pymatuning Creek & OHIO & 1 & & & $\mathrm{X}$ \\
\hline 050301020401 & Sugar Run-Shenango River & OHIO & 1 & & $\mathrm{X}$ & \\
\hline 050301020507 & Hottenbaugh Run-Neshannock Creek & OHIO & 1 & & $\mathrm{X}$ & \\
\hline 050301040101 & McKee Run-Beaver Creek & OHIO & 1 & & $\mathrm{X}$ & \\
\hline 050301050201 & East Branch Wolf Creek & OHIO & 1 & & & $\mathrm{X}$ \\
\hline 050301050202 & Pine Swamp-Wolf Creek & OHIO & 1 & & & $\mathrm{X}$ \\
\hline 050301050303 & McMurray Run-Slippery Rock Creek & OHIO & 1 & & $\mathrm{X}$ & \\
\hline 050301050304 & South Branch Slippery Rock Creek & OHIO & 1 & & $\mathrm{X}$ & \\
\hline 050301050404 & Thorn Creek & OHIO & 1 & & & $\mathrm{X}$ \\
\hline 050301050405 & Glade Creek & OHIO & 1 & & & $\mathrm{X}$ \\
\hline 050301050406 & Breakneck Creek & OHIO & 1 & & & $\mathrm{X}$ \\
\hline 050301050408 & Brush Creek & $\mathrm{OHIO}$ & 1 & & & $\mathrm{X}$ \\
\hline 020401010501 & Hankins Creek-Delaware River & DEL & 2 & & $\mathrm{X}$ & $\mathrm{X}$ \\
\hline 020401010506 & Beaverdam Creek-Delaware River & DEL & 2 & & $\mathrm{X}$ & $\mathrm{X}$ \\
\hline 020401010601 & North Branch Calkins Creek & DEL & 2 & & $\mathrm{X}$ & $\mathrm{X}$ \\
\hline 020401010602 & South Branch Calkins Creek & DEL & 2 & & $\mathrm{X}$ & $\mathrm{X}$ \\
\hline 020401010604 & Peggy Run-Delaware River & DEL & 2 & & $\mathrm{X}$ & $\mathrm{X}$ \\
\hline 020401010605 & Masthope Creek & DEL & 2 & & $\mathrm{X}$ & $\mathrm{X}$ \\
\hline 020401010606 & Westcolang Creek-Delaware River & DEL & 2 & & $\mathrm{X}$ & $\mathrm{X}$ \\
\hline 020401030301 & Upper Middle Creek & DEL & 2 & & $\mathrm{X}$ & $\mathrm{X}$ \\
\hline 020401030401 & Jones Creek & DEL & 2 & & $\mathrm{X}$ & $\mathrm{X}$ \\
\hline 020401030402 & Butternut Creek-West Branch Wallenpaupack Creek & DEL & 2 & & $\mathrm{X}$ & $\mathrm{X}$ \\
\hline 020401030502 & East Branch Wallenpaupack & DEL & 2 & & $\mathrm{X}$ & $\mathrm{X}$ \\
\hline 020401030504 & Ariel Creek & DEL & 2 & & $\mathrm{X}$ & $\mathrm{X}$ \\
\hline 020401030505 & Lake Wallenpaupack-Wallenpaupack Creek & DEL & 2 & & $\mathrm{X}$ & $\mathrm{X}$ \\
\hline
\end{tabular}


Appendix 5. Complete listing of HUC12 watersheds in Pennsylvania and the Susquehanna River Basin in Pennsylvania and New York with basin characteristic, geographic, or streamflow correlation gaps.-Continued

[HUC12, 12-digit hydrologic unit code; DEL, Delaware River Basin; STLAW, Saint Lawrence River Basin; OHIO, Ohio River Basin; POT, Potomac River Basin; SUSQ, Susquehanna River Basin; SUSQ NY, Susquehanna River Basin watersheds entirely in New York; X, indicates gap]

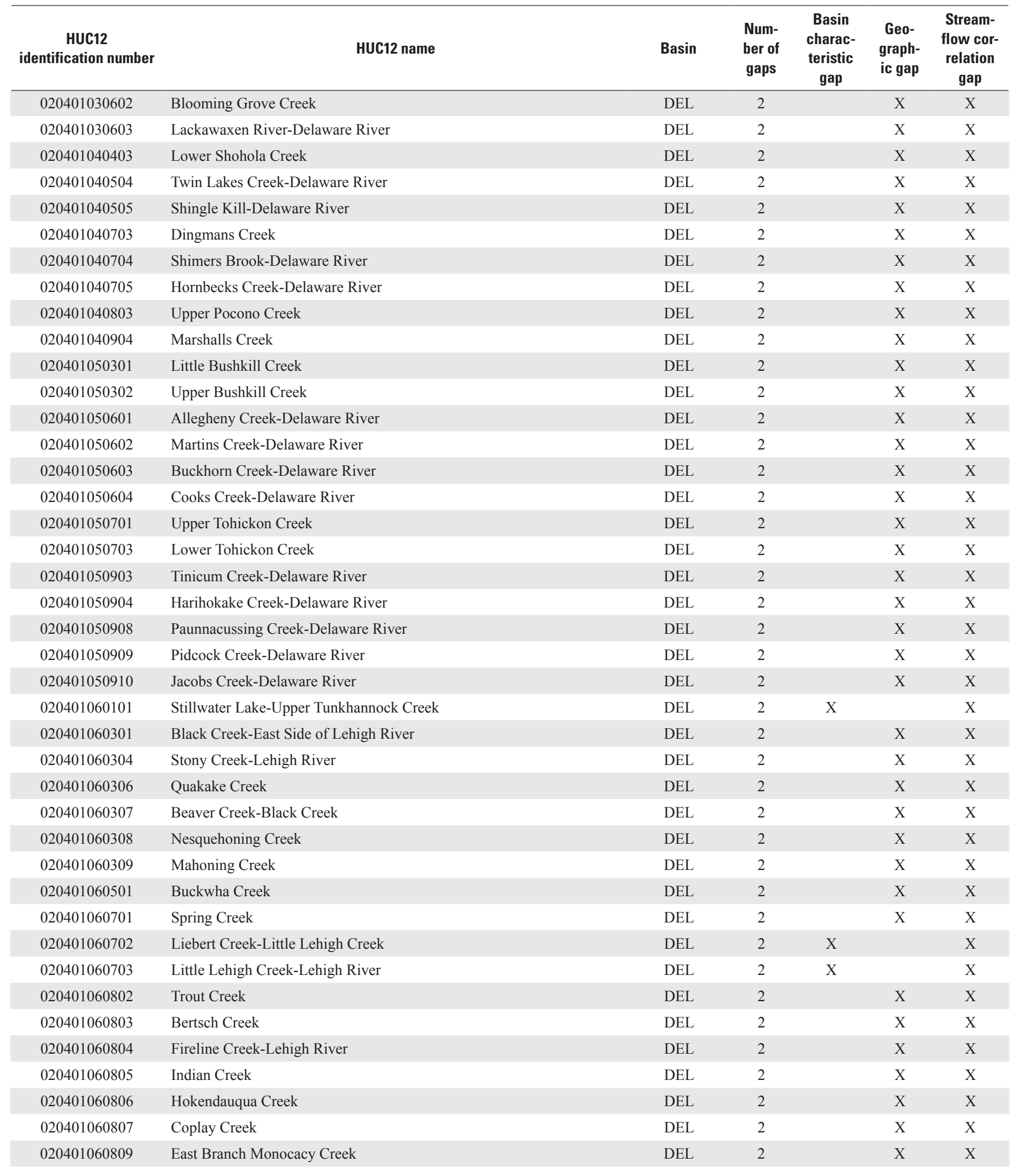


Appendix 5. Complete listing of HUC12 watersheds in Pennsylvania and the Susquehanna River Basin in Pennsylvania and New York with basin characteristic, geographic, or streamflow correlation gaps.-Continued

[HUC12, 12-digit hydrologic unit code; DEL, Delaware River Basin; STLAW, Saint Lawrence River Basin; OHIO, Ohio River Basin; POT, Potomac River Basin; SUSQ, Susquehanna River Basin; SUSQ NY, Susquehanna River Basin watersheds entirely in New York; X, indicates gap]

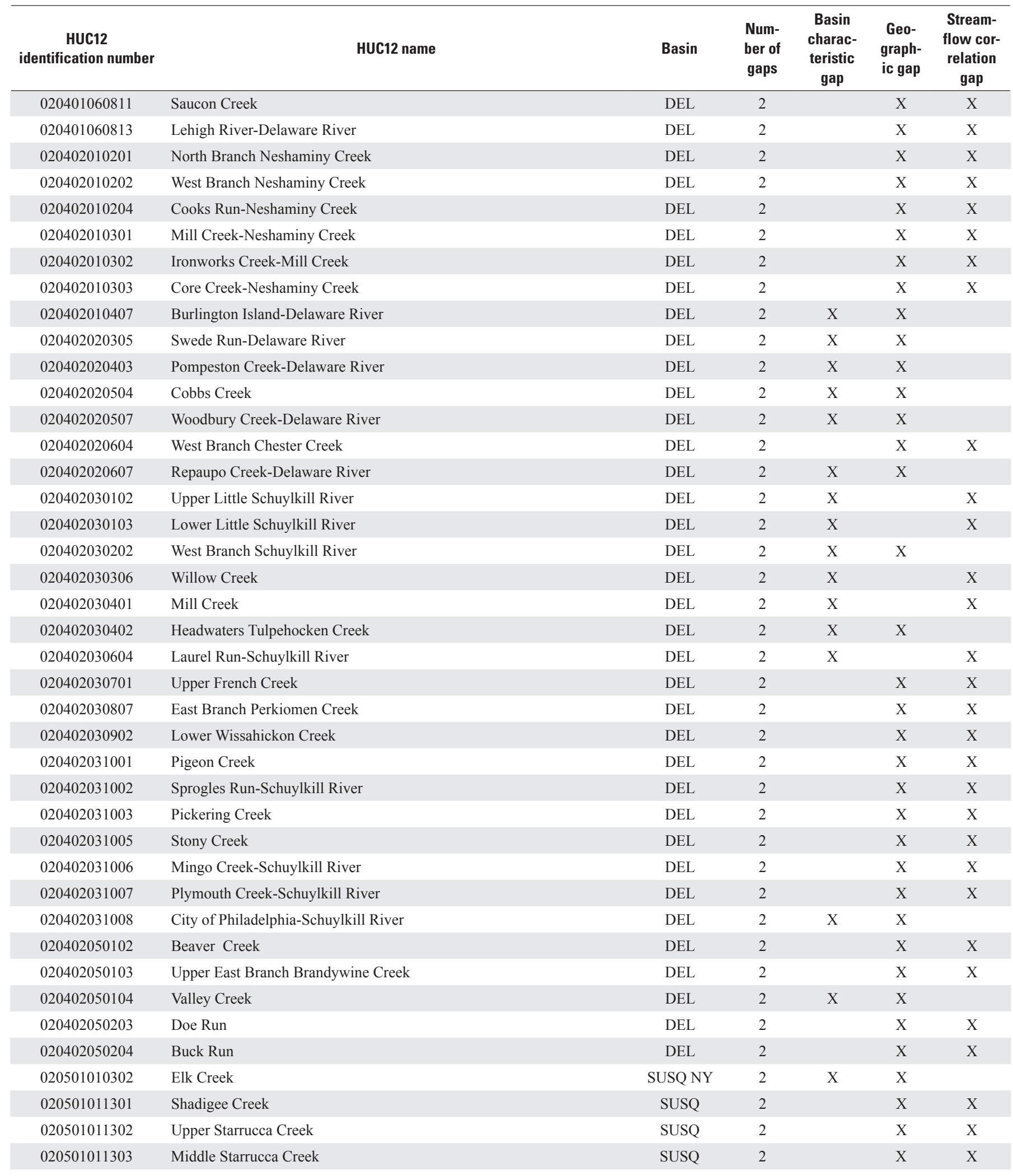


Appendix 5. Complete listing of HUC12 watersheds in Pennsylvania and the Susquehanna River Basin in Pennsylvania and New York with basin characteristic, geographic, or streamflow correlation gaps.-Continued

[HUC12, 12-digit hydrologic unit code; DEL, Delaware River Basin; STLAW, Saint Lawrence River Basin; OHIO, Ohio River Basin; POT, Potomac River Basin; SUSQ, Susquehanna River Basin; SUSQ NY, Susquehanna River Basin watersheds entirely in New York; X, indicates gap]

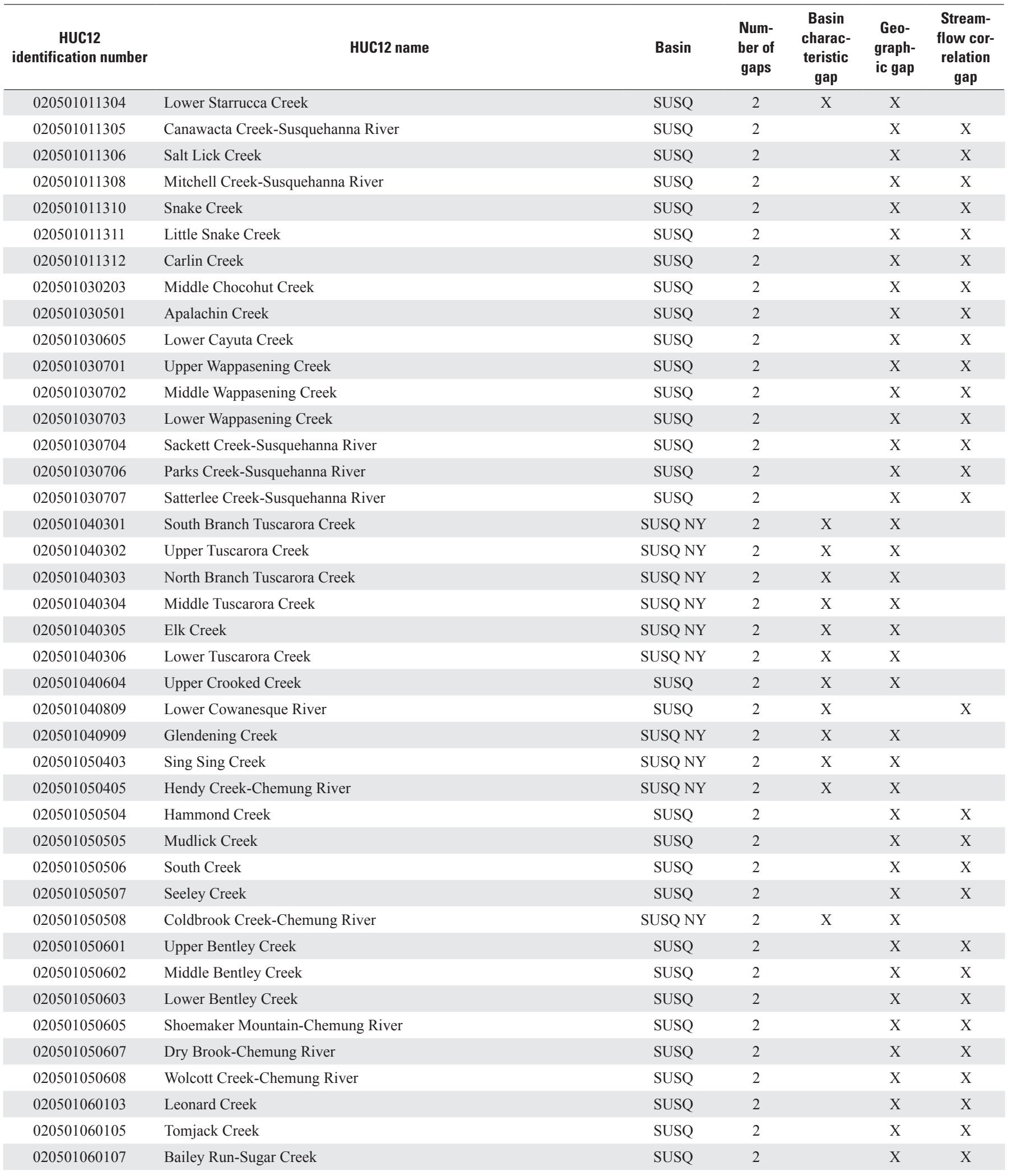


Appendix 5. Complete listing of HUC12 watersheds in Pennsylvania and the Susquehanna River Basin in Pennsylvania and New York with basin characteristic, geographic, or streamflow correlation gaps.-Continued

[HUC12, 12-digit hydrologic unit code; DEL, Delaware River Basin; STLAW, Saint Lawrence River Basin; OHIO, Ohio River Basin; POT, Potomac River Basin; SUSQ, Susquehanna River Basin; SUSQ NY, Susquehanna River Basin watersheds entirely in New York; X, indicates gap]

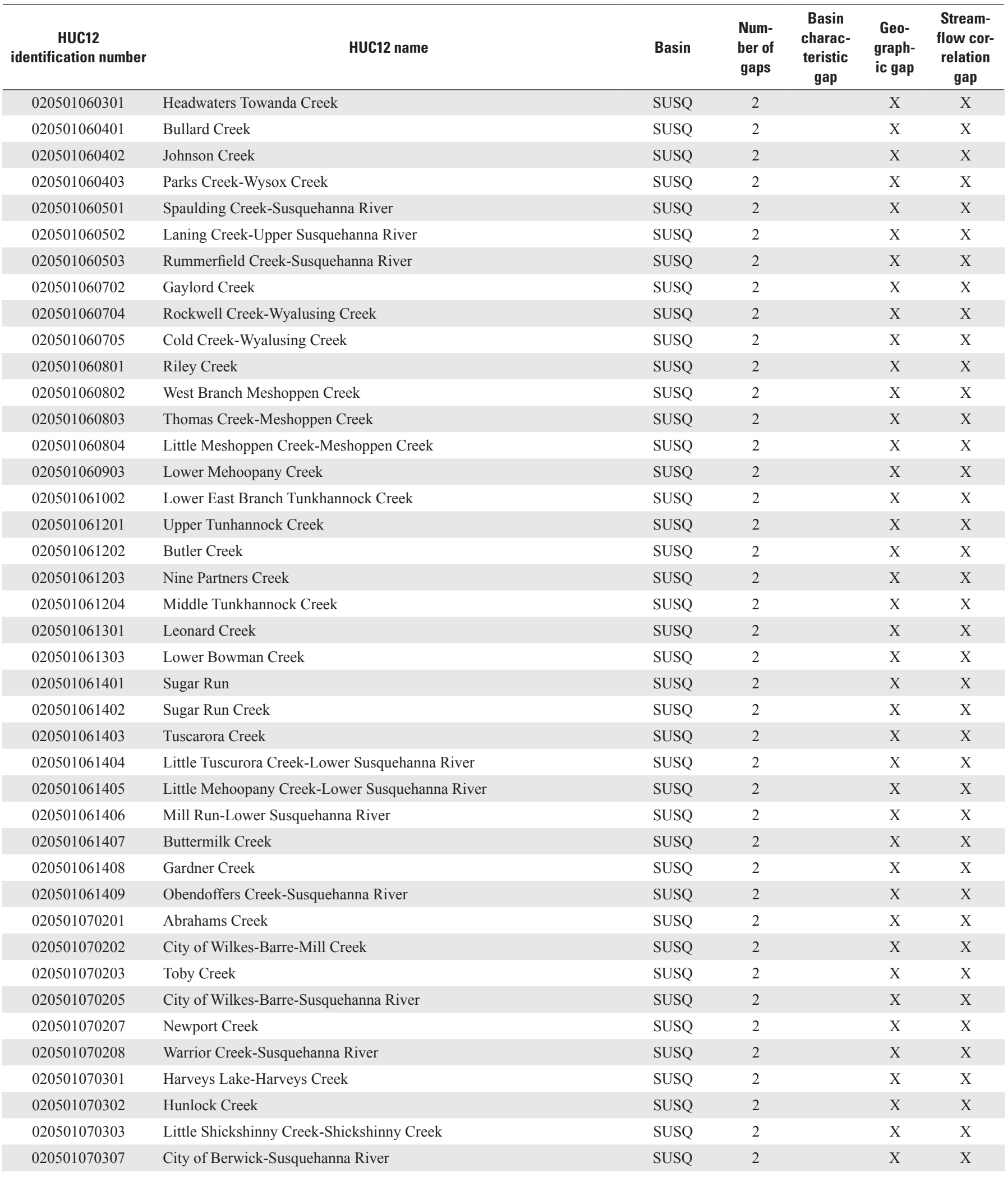


Appendix 5. Complete listing of HUC12 watersheds in Pennsylvania and the Susquehanna River Basin in Pennsylvania and New York with basin characteristic, geographic, or streamflow correlation gaps.-Continued

[HUC12, 12-digit hydrologic unit code; DEL, Delaware River Basin; STLAW, Saint Lawrence River Basin; OHIO, Ohio River Basin; POT, Potomac River Basin; SUSQ, Susquehanna River Basin; SUSQ NY, Susquehanna River Basin watersheds entirely in New York; X, indicates gap]

\begin{tabular}{|c|c|c|c|c|c|c|}
\hline $\begin{array}{c}\text { HUC12 } \\
\text { identification number }\end{array}$ & HUC12 name & Basin & $\begin{array}{c}\text { Num- } \\
\text { ber of } \\
\text { gaps }\end{array}$ & $\begin{array}{l}\text { Basin } \\
\text { charac- } \\
\text { teristic } \\
\text { gap }\end{array}$ & $\begin{array}{l}\text { Geo- } \\
\text { graph- } \\
\text { ic gap }\end{array}$ & $\begin{array}{l}\text { Stream- } \\
\text { flow cor- } \\
\text { relation } \\
\text { gap }\end{array}$ \\
\hline 020501070403 & Nescopeck Creek-Susquehanna River & SUSQ & 2 & & $\mathrm{X}$ & $\mathrm{X}$ \\
\hline 020501070501 & Headwaters Huntington Creek & SUSQ & 2 & $\mathrm{X}$ & & $\mathrm{X}$ \\
\hline 020501070703 & West Creek & SUSQ & 2 & & $\mathrm{X}$ & $\mathrm{X}$ \\
\hline 020501070801 & Little Catawissa Creek & SUSQ & 2 & & $\mathrm{X}$ & $\mathrm{X}$ \\
\hline 020501070802 & Tomicken Creek & SUSQ & 2 & & $\mathrm{X}$ & $\mathrm{X}$ \\
\hline 020501070803 & Messers Run-Catawissa Creek & SUSQ & 2 & & $\mathrm{X}$ & $\mathrm{X}$ \\
\hline 020501070902 & Roaring Creek-Susquehanna River & SUSQ & 2 & & $\mathrm{X}$ & $\mathrm{X}$ \\
\hline 020501071001 & Briar Creek & SUSQ & 2 & & $\mathrm{X}$ & $\mathrm{X}$ \\
\hline 020501071002 & Tenmile Creek-Susquehanna River & SUSQ & 2 & & $\mathrm{X}$ & $\mathrm{X}$ \\
\hline 020501071003 & Logan Run & SUSQ & 2 & & $\mathrm{X}$ & $\mathrm{X}$ \\
\hline 020501071004 & Sechler Run & SUSQ & 2 & & $\mathrm{X}$ & $\mathrm{X}$ \\
\hline 020501071005 & Mahoning Creek & SUSQ & 2 & & $\mathrm{X}$ & $\mathrm{X}$ \\
\hline 020501071006 & City of Sunbury-Susquehanna River & SUSQ & 2 & & $\mathrm{X}$ & $\mathrm{X}$ \\
\hline 020502010201 & Upper Anderson Creek & SUSQ & 2 & & $\mathrm{X}$ & $\mathrm{X}$ \\
\hline 020502010202 & Lower Anderson Creek & SUSQ & 2 & & $\mathrm{X}$ & $\mathrm{X}$ \\
\hline 020502010302 & Slate Lick Run & SUSQ & 2 & & $\mathrm{X}$ & $\mathrm{X}$ \\
\hline 020502010507 & Black Moshannon Creek & SUSQ & 2 & $\mathrm{X}$ & $\mathrm{X}$ & \\
\hline 020502010602 & Gifford Run-Mosquito Creek & SUSQ & 2 & & $\mathrm{X}$ & $\mathrm{X}$ \\
\hline 020502010701 & Lick Run & SUSQ & 2 & & $\mathrm{X}$ & $\mathrm{X}$ \\
\hline 020502010704 & Deer Creek & SUSQ & 2 & & $\mathrm{X}$ & $\mathrm{X}$ \\
\hline 020502010705 & Sandy Creek & SUSQ & 2 & & $\mathrm{X}$ & $\mathrm{X}$ \\
\hline 020502010706 & Alder Run & SUSQ & 2 & & $\mathrm{X}$ & $\mathrm{X}$ \\
\hline 020502010708 & Upper Three Runs & SUSQ & 2 & & $\mathrm{X}$ & $\mathrm{X}$ \\
\hline 020502010709 & Saltlick Run-West Branch Susquehanna River & SUSQ & 2 & & $\mathrm{X}$ & $\mathrm{X}$ \\
\hline 020502020201 & Elk Fork-Driftwood Branch Sinnemahoning Creek & SUSQ & 2 & $\mathrm{X}$ & $\mathrm{X}$ & \\
\hline 020502020203 & North Creek & SUSQ & 2 & $\mathrm{X}$ & $\mathrm{X}$ & \\
\hline 020502020206 & Sterling Run & SUSQ & 2 & $\mathrm{X}$ & & $\mathrm{X}$ \\
\hline 020502020301 & Upper Bennett Branch Sinnemahoning Creek & SUSQ & 2 & & $\mathrm{X}$ & $\mathrm{X}$ \\
\hline 020502020302 & Kersey Run & SUSQ & 2 & & $\mathrm{X}$ & $\mathrm{X}$ \\
\hline
\end{tabular}


Appendix 5. Complete listing of HUC12 watersheds in Pennsylvania and the Susquehanna River Basin in Pennsylvania and New York with basin characteristic, geographic, or streamflow correlation gaps.-Continued

[HUC12, 12-digit hydrologic unit code; DEL, Delaware River Basin; STLAW, Saint Lawrence River Basin; OHIO, Ohio River Basin; POT, Potomac River Basin; SUSQ, Susquehanna River Basin; SUSQ NY, Susquehanna River Basin watersheds entirely in New York; X, indicates gap]

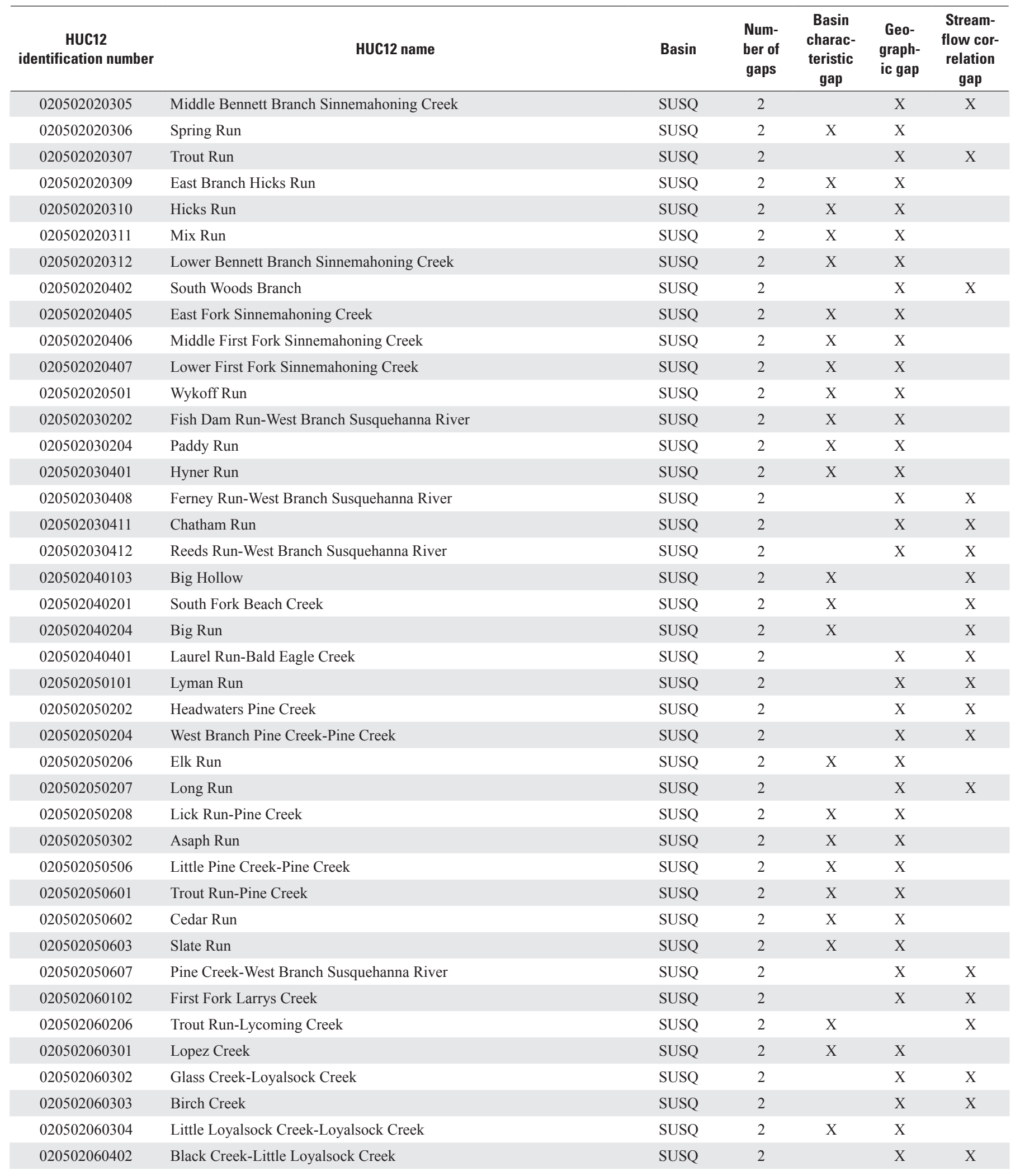


Appendix 5. Complete listing of HUC12 watersheds in Pennsylvania and the Susquehanna River Basin in Pennsylvania and New York with basin characteristic, geographic, or streamflow correlation gaps.-Continued

[HUC12, 12-digit hydrologic unit code; DEL, Delaware River Basin; STLAW, Saint Lawrence River Basin; OHIO, Ohio River Basin; POT, Potomac River Basin; SUSQ, Susquehanna River Basin; SUSQ NY, Susquehanna River Basin watersheds entirely in New York; X, indicates gap]

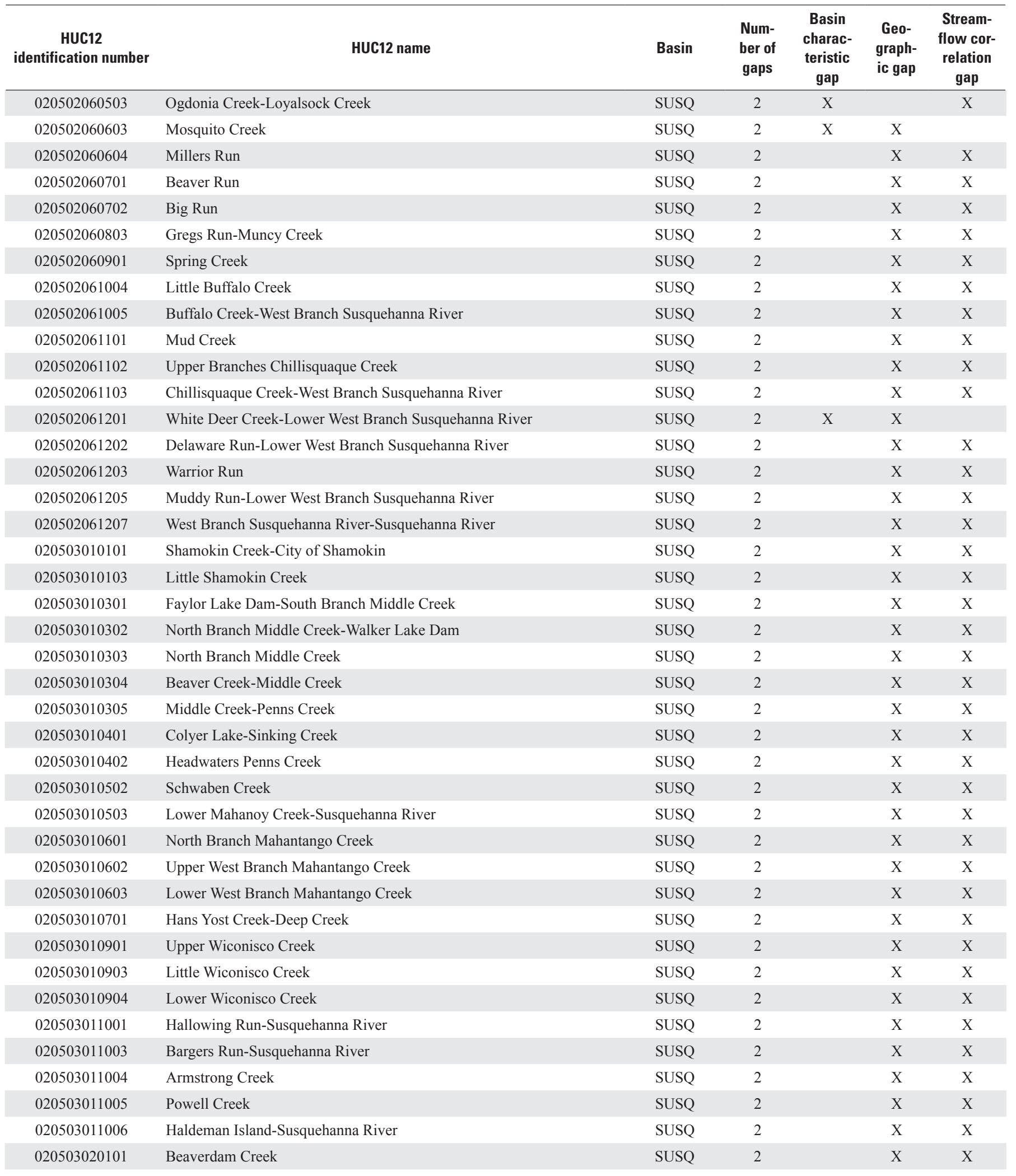


Appendix 5. Complete listing of HUC12 watersheds in Pennsylvania and the Susquehanna River Basin in Pennsylvania and New York with basin characteristic, geographic, or streamflow correlation gaps.-Continued

[HUC12, 12-digit hydrologic unit code; DEL, Delaware River Basin; STLAW, Saint Lawrence River Basin; OHIO, Ohio River Basin; POT, Potomac River Basin; SUSQ, Susquehanna River Basin; SUSQ NY, Susquehanna River Basin watersheds entirely in New York; X, indicates gap]

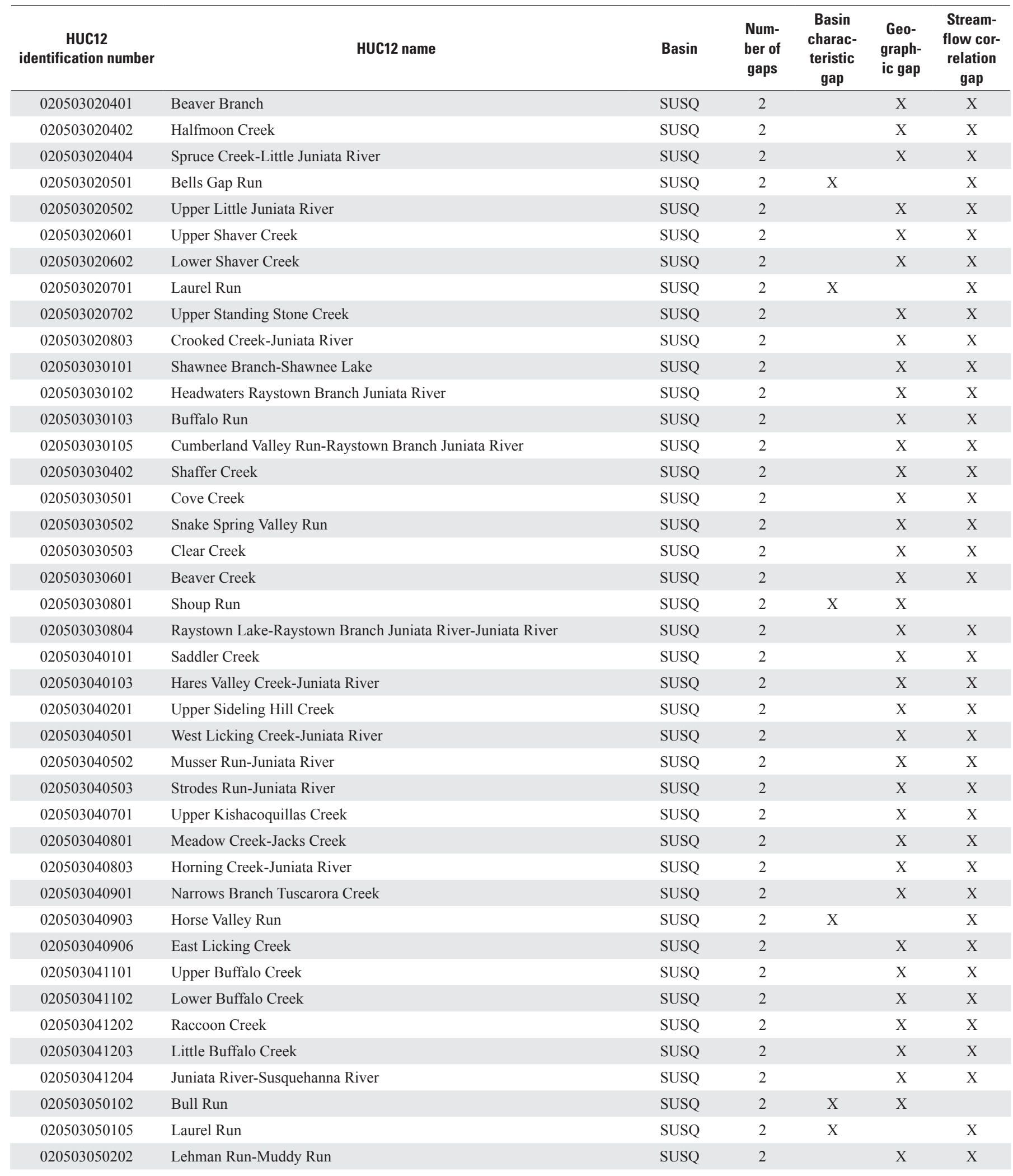


Appendix 5. Complete listing of HUC12 watersheds in Pennsylvania and the Susquehanna River Basin in Pennsylvania and New York with basin characteristic, geographic, or streamflow correlation gaps.-Continued

[HUC12, 12-digit hydrologic unit code; DEL, Delaware River Basin; STLAW, Saint Lawrence River Basin; OHIO, Ohio River Basin; POT, Potomac River Basin; SUSQ, Susquehanna River Basin; SUSQ NY, Susquehanna River Basin watersheds entirely in New York; X, indicates gap]

\begin{tabular}{|c|c|c|c|c|c|c|}
\hline $\begin{array}{c}\text { HUC12 } \\
\text { identification number }\end{array}$ & HUC12 name & Basin & $\begin{array}{l}\text { Num- } \\
\text { ber of } \\
\text { gaps }\end{array}$ & $\begin{array}{c}\text { Basin } \\
\text { charac- } \\
\text { teristic } \\
\text { gap }\end{array}$ & $\begin{array}{l}\text { Geo- } \\
\text { graph- } \\
\text { ic gap }\end{array}$ & $\begin{array}{l}\text { Stream- } \\
\text { flow cor- } \\
\text { relation } \\
\text { gap }\end{array}$ \\
\hline 020503050301 & Thompson Creek-Burd Run & SUSQ & 2 & & $\mathrm{X}$ & $\mathrm{X}$ \\
\hline 020503050302 & Middle Spring Creek & SUSQ & 2 & & $\mathrm{X}$ & $\mathrm{X}$ \\
\hline 020503050401 & Mount Rock Spring Creek & SUSQ & 2 & $\mathrm{X}$ & & $\mathrm{X}$ \\
\hline 020503050402 & Alexanders Spring Creek & SUSQ & 2 & $\mathrm{X}$ & & $\mathrm{X}$ \\
\hline 020503050404 & Letort Spring Run & SUSQ & 2 & $\mathrm{X}$ & & $\mathrm{X}$ \\
\hline 020503050405 & Hogestown Run & SUSQ & 2 & $\mathrm{X}$ & & $\mathrm{X}$ \\
\hline 020503050502 & Upper Yellow Breeches Creek & SUSQ & 2 & & $\mathrm{X}$ & $\mathrm{X}$ \\
\hline 020503050503 & Mountain Creek & SUSQ & 2 & & $\mathrm{X}$ & $\mathrm{X}$ \\
\hline 020503050504 & Middle Yellow Breeches Creek & SUSQ & 2 & & $\mathrm{X}$ & $\mathrm{X}$ \\
\hline 020503050505 & Lower Yellow Breeches Creek & SUSQ & 2 & & $\mathrm{X}$ & $\mathrm{X}$ \\
\hline 020503050602 & Good Spring Creek-Upper Swatara Creek & SUSQ & 2 & & $\mathrm{X}$ & $\mathrm{X}$ \\
\hline 020503050604 & Mill Creek & SUSQ & 2 & $\mathrm{X}$ & & $\mathrm{X}$ \\
\hline 020503050801 & Killinger Creek & SUSQ & 2 & & $\mathrm{X}$ & $\mathrm{X}$ \\
\hline 020503050802 & Snitz Creek-Quittapahilla Creek & SUSQ & 2 & & $\mathrm{X}$ & $\mathrm{X}$ \\
\hline 020503050901 & Reeds Run-Swatara Creek & SUSQ & 2 & $\mathrm{X}$ & & $\mathrm{X}$ \\
\hline 020503050902 & Bow Creek-Swatara Creek & SUSQ & 2 & & $\mathrm{X}$ & $\mathrm{X}$ \\
\hline 020503051009 & Fishing Creek-York County & SUSQ & 2 & & $\mathrm{X}$ & $\mathrm{X}$ \\
\hline 020503051010 & Conewago Creek & SUSQ & 2 & & $\mathrm{X}$ & $\mathrm{X}$ \\
\hline 020503060101 & Headwaters South Branch Conewago Creek & SUSQ & 2 & & $\mathrm{X}$ & $\mathrm{X}$ \\
\hline 020503060201 & Opossum Creek & SUSQ & 2 & & $\mathrm{X}$ & $\mathrm{X}$ \\
\hline 020503060202 & Headwaters Conewago Creek & SUSQ & 2 & & $\mathrm{X}$ & $\mathrm{X}$ \\
\hline 020503060204 & Boro of East Berlin-Conewago Creek & SUSQ & 2 & & $\mathrm{X}$ & $\mathrm{X}$ \\
\hline 020503060301 & Latimore Creek & SUSQ & 2 & & $\mathrm{X}$ & $\mathrm{X}$ \\
\hline 020503060302 & North Branch Bermudian Creek & SUSQ & 2 & & $\mathrm{X}$ & $\mathrm{X}$ \\
\hline 020503060303 & Mud Run-Bermudian Creek & SUSQ & 2 & & $\mathrm{X}$ & $\mathrm{X}$ \\
\hline 020503060401 & Upper Little Conewago Creek & SUSQ & 2 & & $\mathrm{X}$ & $\mathrm{X}$ \\
\hline 020503060501 & Beaver Creek & SUSQ & 2 & & $\mathrm{X}$ & $\mathrm{X}$ \\
\hline 020503060503 & Conewago Lake-Beaver Creek & SUSQ & 2 & & $\mathrm{X}$ & $\mathrm{X}$ \\
\hline 020503060504 & Conewago Creek-Susquehanna River & SUSQ & 2 & & $\mathrm{X}$ & $\mathrm{X}$ \\
\hline
\end{tabular}


Appendix 5. Complete listing of HUC12 watersheds in Pennsylvania and the Susquehanna River Basin in Pennsylvania and New York with basin characteristic, geographic, or streamflow correlation gaps.-Continued

[HUC12, 12-digit hydrologic unit code; DEL, Delaware River Basin; STLAW, Saint Lawrence River Basin; OHIO, Ohio River Basin; POT, Potomac River Basin; SUSQ, Susquehanna River Basin; SUSQ NY, Susquehanna River Basin watersheds entirely in New York; X, indicates gap]

\begin{tabular}{|c|c|c|c|c|c|c|}
\hline $\begin{array}{c}\text { HUC12 } \\
\text { identification number }\end{array}$ & HUC12 name & Basin & $\begin{array}{c}\text { Num- } \\
\text { ber of } \\
\text { gaps }\end{array}$ & $\begin{array}{c}\text { Basin } \\
\text { charac- } \\
\text { teristic } \\
\text { gap }\end{array}$ & $\begin{array}{l}\text { Geo- } \\
\text { graph- } \\
\text { ic gap }\end{array}$ & $\begin{array}{c}\text { Stream- } \\
\text { flow cor- } \\
\text { relation } \\
\text { gap } \\
\end{array}$ \\
\hline 020503060706 & Mill Creek & SUSQ & 2 & & $\mathrm{X}$ & $\mathrm{X}$ \\
\hline 020503060707 & Codorus Creek-Susquehanna River & SUSQ & 2 & & $\mathrm{X}$ & $\mathrm{X}$ \\
\hline 020503060801 & Upper Chickies Creek & SUSQ & 2 & & $\mathrm{X}$ & $\mathrm{X}$ \\
\hline 020503060901 & Little Cocalico Creek-Cocalico Creek & SUSQ & 2 & & $\mathrm{X}$ & $\mathrm{X}$ \\
\hline 020503060902 & Middle Creek & SUSQ & 2 & & $\mathrm{X}$ & $\mathrm{X}$ \\
\hline 020503060903 & Hammer Creek & SUSQ & 2 & & $\mathrm{X}$ & $\mathrm{X}$ \\
\hline 020503061001 & Millers Run-Little Conestoga Creek & SUSQ & 2 & $\mathrm{X}$ & & $\mathrm{X}$ \\
\hline 020503061002 & West Branch Little Conestoga Creek-Little Conestoga Creek & SUSQ & 2 & $\mathrm{X}$ & & $\mathrm{X}$ \\
\hline 020503061101 & Little Muddy Creek & SUSQ & 2 & & $\mathrm{X}$ & $\mathrm{X}$ \\
\hline 020503061102 & Muddy Creek & SUSQ & 2 & & $\mathrm{X}$ & $\mathrm{X}$ \\
\hline 020503061103 & Upper Conestoga River & SUSQ & 2 & & $\mathrm{X}$ & $\mathrm{X}$ \\
\hline 020503061105 & Lititz Run & SUSQ & 2 & $\mathrm{X}$ & & $\mathrm{X}$ \\
\hline 020503061106 & Muddy Run-Mill Creek & SUSQ & 2 & $\mathrm{X}$ & & $\mathrm{X}$ \\
\hline 020503061107 & Lower Conestoga River & SUSQ & 2 & $\mathrm{X}$ & & $\mathrm{X}$ \\
\hline 020503061201 & Headwaters Pequea Creek & SUSQ & 2 & & $\mathrm{X}$ & $\mathrm{X}$ \\
\hline 020503061202 & Eshleman Run-Pequea Creek & SUSQ & 2 & $\mathrm{X}$ & & $\mathrm{X}$ \\
\hline 020503061204 & Climbers Run-Pequea Creek & SUSQ & 2 & $\mathrm{X}$ & & $\mathrm{X}$ \\
\hline 020503061301 & North Branch Muddy Creek & SUSQ & 2 & & $\mathrm{X}$ & $\mathrm{X}$ \\
\hline 020503061402 & Valley Creek-East Branch Octoraro Creek & SUSQ & 2 & & $\mathrm{X}$ & $\mathrm{X}$ \\
\hline 020503061403 & Muddy Run-East Branch Octoraro Creek & SUSQ & 2 & & $\mathrm{X}$ & $\mathrm{X}$ \\
\hline 020503061601 & Headwaters Deer Creek & SUSQ & 2 & & $\mathrm{X}$ & $\mathrm{X}$ \\
\hline 020503061703 & Kreutz Creek & SUSQ & 2 & & $\mathrm{X}$ & $\mathrm{X}$ \\
\hline 020503061705 & Fishing Creek & SUSQ & 2 & & $\mathrm{X}$ & $\mathrm{X}$ \\
\hline 020503061707 & Otter Creek & SUSQ & 2 & & $\mathrm{X}$ & $\mathrm{X}$ \\
\hline 020503061708 & Muddy Run-Susquehanna River & SUSQ & 2 & & $\mathrm{X}$ & $\mathrm{X}$ \\
\hline 020600020101 & Little North East Creek & POT & 2 & $\mathrm{X}$ & $\mathrm{X}$ & \\
\hline 020600020201 & East Branch Big Elk Creek & POT & 2 & & $\mathrm{X}$ & $\mathrm{X}$ \\
\hline 020600020202 & Little Elk Creek & РOT & 2 & $\mathrm{X}$ & $\mathrm{X}$ & \\
\hline 020600020203 & Big Elk Creek & POT & 2 & $\mathrm{X}$ & $\mathrm{X}$ & \\
\hline 020600030401 & Little Falls & POT & 2 & & $\mathrm{X}$ & $\mathrm{X}$ \\
\hline 020700020503 & Little Wills Creek & РOT & 2 & & $\mathrm{X}$ & $\mathrm{X}$ \\
\hline 020700020504 & Gladdens Run & POT & 2 & & $\mathrm{X}$ & $\mathrm{X}$ \\
\hline 020700020505 & Jennings Run & POT & 2 & & $\mathrm{X}$ & $\mathrm{X}$ \\
\hline 020700020506 & Shaffers Run-Wills Creek & POT & 2 & & $\mathrm{X}$ & $\mathrm{X}$ \\
\hline 020700020602 & Rocky Gap Run-Evitts Creek & POT & 2 & & $\mathrm{X}$ & $\mathrm{X}$ \\
\hline 020700030101 & Wilson Run-Elk Lick Creek & POT & 2 & & $\mathrm{X}$ & $\mathrm{X}$ \\
\hline 020700030104 & Sweet Root Creek-Town Creek & POT & 2 & & $\mathrm{X}$ & $\mathrm{X}$ \\
\hline 020700030301 & Upper Fifteenmile Creek & POT & 2 & $\mathrm{X}$ & $\mathrm{X}$ & \\
\hline 020700030304 & Crooked Run-Sideling Hill Creek & POT & 2 & $\mathrm{X}$ & $\mathrm{X}$ & \\
\hline 020700030305 & Bear Creek-Sideling Hill Creek & POT & 2 & $\mathrm{X}$ & $\mathrm{X}$ & \\
\hline 020700030403 & Piney Creek & РОТ & 2 & $\mathrm{X}$ & $\mathrm{X}$ & \\
\hline
\end{tabular}


Appendix 5. Complete listing of HUC12 watersheds in Pennsylvania and the Susquehanna River Basin in Pennsylvania and New York with basin characteristic, geographic, or streamflow correlation gaps.-Continued

[HUC12, 12-digit hydrologic unit code; DEL, Delaware River Basin; STLAW, Saint Lawrence River Basin; OHIO, Ohio River Basin; POT, Potomac River Basin; SUSQ, Susquehanna River Basin; SUSQ NY, Susquehanna River Basin watersheds entirely in New York; X, indicates gap]

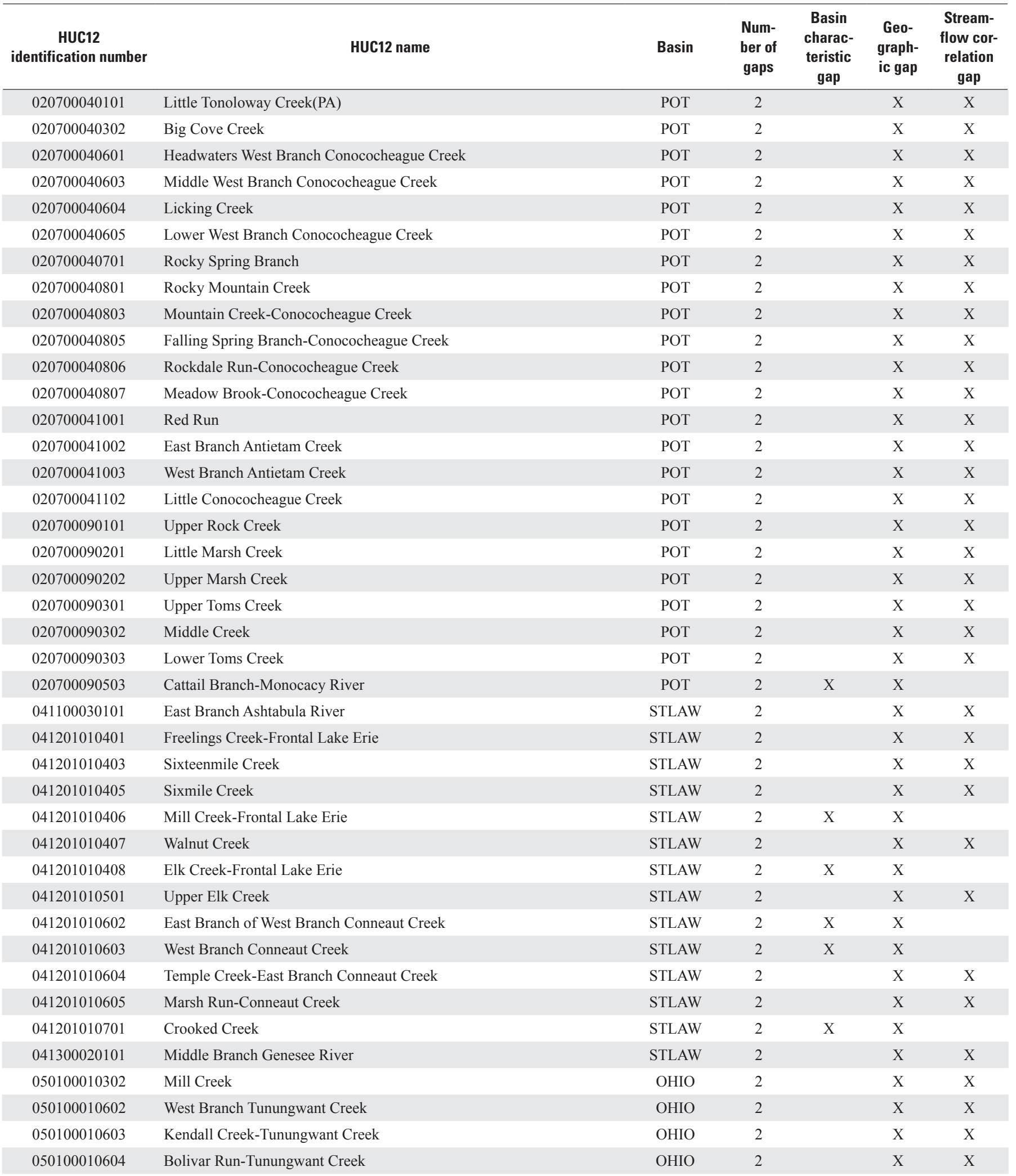


Appendix 5. Complete listing of HUC12 watersheds in Pennsylvania and the Susquehanna River Basin in Pennsylvania and New York with basin characteristic, geographic, or streamflow correlation gaps.-Continued

[HUC12, 12-digit hydrologic unit code; DEL, Delaware River Basin; STLAW, Saint Lawrence River Basin; OHIO, Ohio River Basin; POT, Potomac River Basin; SUSQ, Susquehanna River Basin; SUSQ NY, Susquehanna River Basin watersheds entirely in New York; X, indicates gap]

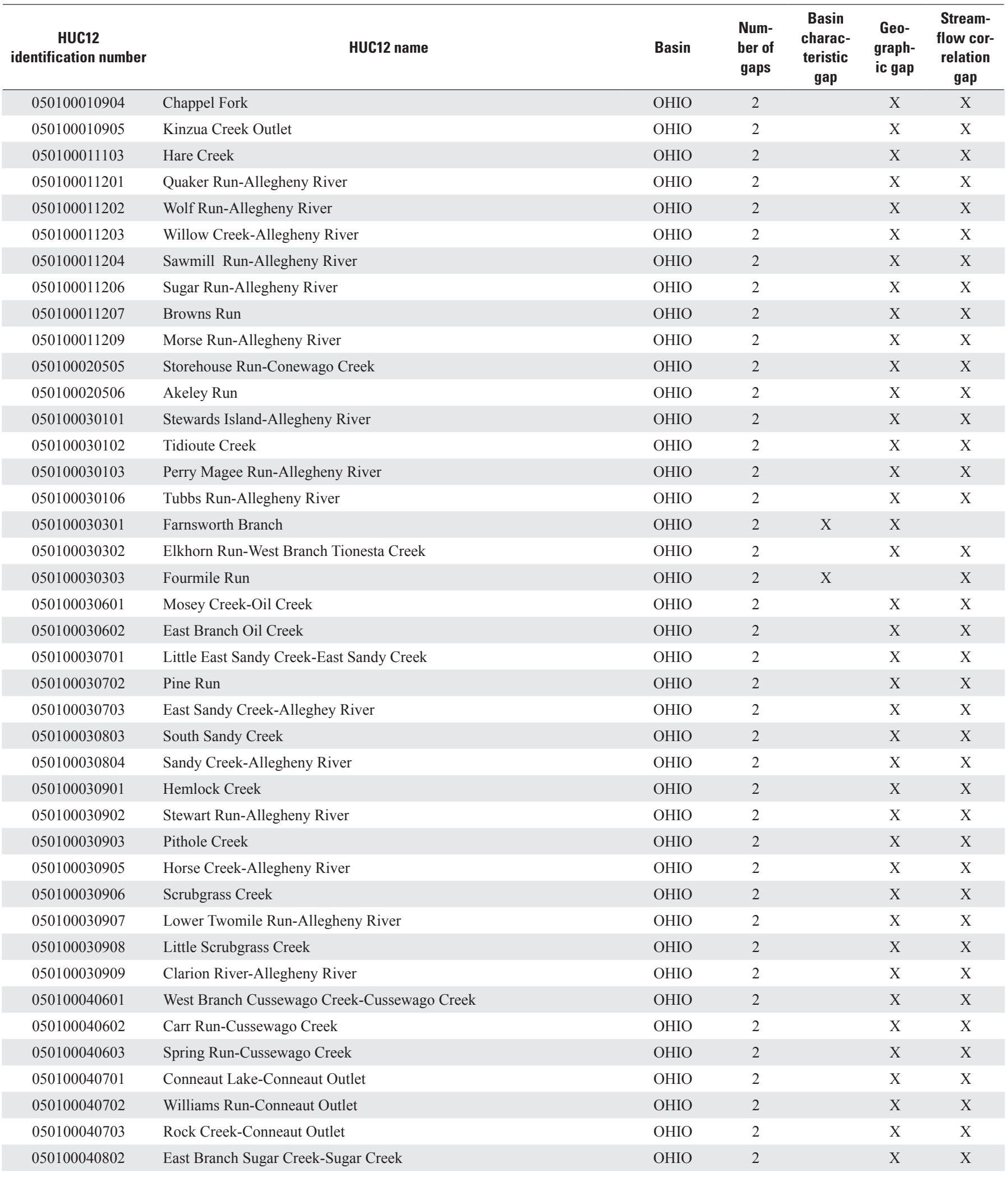


Appendix 5. Complete listing of HUC12 watersheds in Pennsylvania and the Susquehanna River Basin in Pennsylvania and New York with basin characteristic, geographic, or streamflow correlation gaps.-Continued

[HUC12, 12-digit hydrologic unit code; DEL, Delaware River Basin; STLAW, Saint Lawrence River Basin; OHIO, Ohio River Basin; POT, Potomac River Basin; SUSQ, Susquehanna River Basin; SUSQ NY, Susquehanna River Basin watersheds entirely in New York; X, indicates gap]

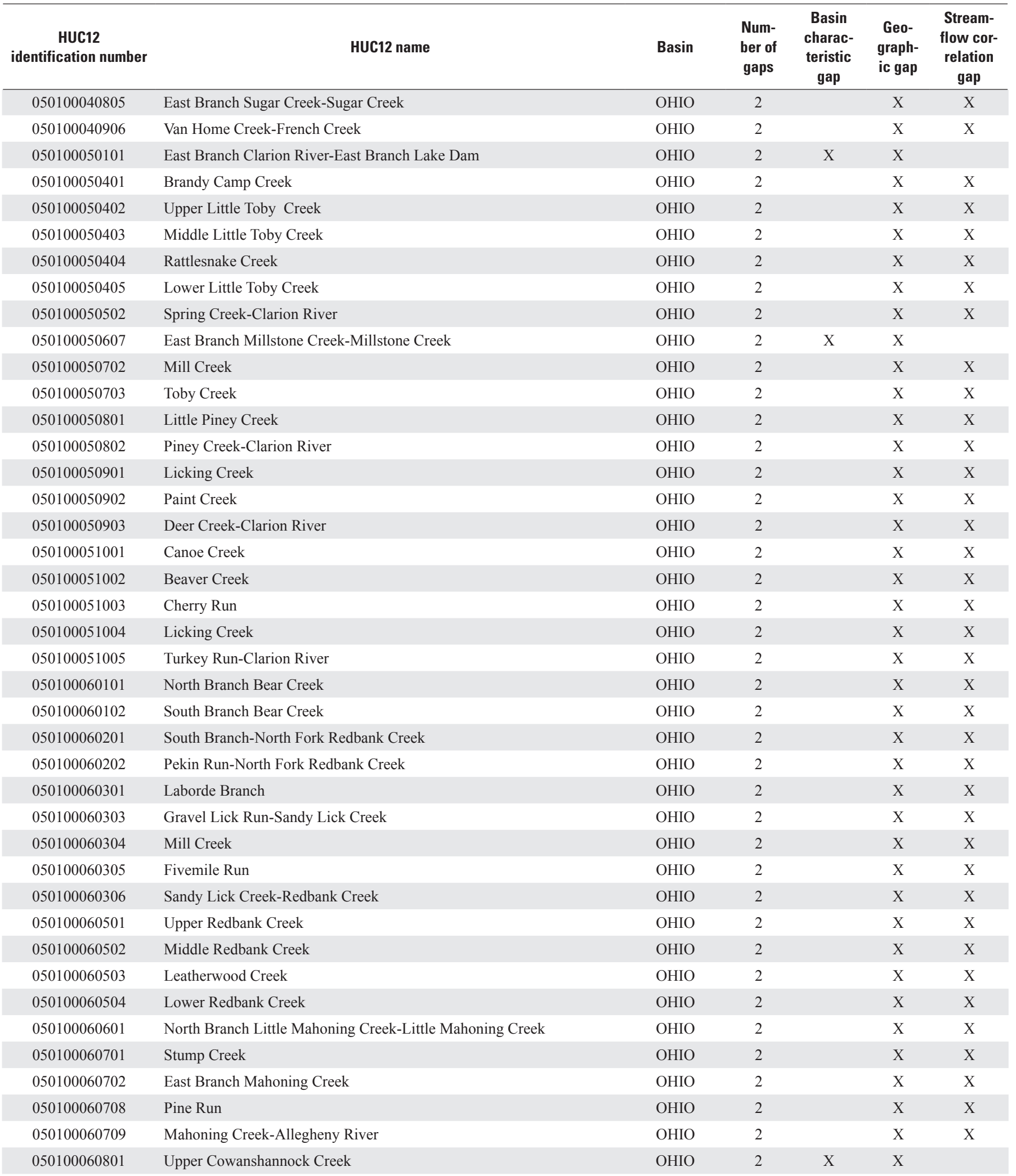


Appendix 5. Complete listing of HUC12 watersheds in Pennsylvania and the Susquehanna River Basin in Pennsylvania and New York with basin characteristic, geographic, or streamflow correlation gaps.-Continued

[HUC12, 12-digit hydrologic unit code; DEL, Delaware River Basin; STLAW, Saint Lawrence River Basin; OHIO, Ohio River Basin; POT, Potomac River Basin; SUSQ, Susquehanna River Basin; SUSQ NY, Susquehanna River Basin watersheds entirely in New York; X, indicates gap]

\begin{tabular}{|c|c|c|c|c|c|c|}
\hline $\begin{array}{c}\text { HUC12 } \\
\text { identification number }\end{array}$ & HUC12 name & Basin & $\begin{array}{c}\text { Num- } \\
\text { ber of } \\
\text { gaps }\end{array}$ & $\begin{array}{c}\text { Basin } \\
\text { charac- } \\
\text { teristic } \\
\text { gap }\end{array}$ & $\begin{array}{l}\text { Geo- } \\
\text { graph- } \\
\text { ic gap }\end{array}$ & $\begin{array}{l}\text { Stream- } \\
\text { flow cor- } \\
\text { relation } \\
\text { gap }\end{array}$ \\
\hline 050100060802 & Lower Cowanshannock Creek & OHIO & 2 & & $\mathrm{X}$ & $\mathrm{X}$ \\
\hline 050100061001 & Headwaters Crooked Creek & OHIO & 2 & & $\mathrm{X}$ & $\mathrm{X}$ \\
\hline 050100061102 & Catfish Run-Allegheny River & OHIO & 2 & & $\mathrm{X}$ & $\mathrm{X}$ \\
\hline 050100061104 & North Fork Pine Creek & OHIO & 2 & & $\mathrm{X}$ & $\mathrm{X}$ \\
\hline 050100061105 & Limestone Run-Allegheny River & OHIO & 2 & & $\mathrm{X}$ & $\mathrm{X}$ \\
\hline 050100061106 & Glade Run & $\mathrm{OHIO}$ & 2 & & $\mathrm{X}$ & $\mathrm{X}$ \\
\hline 050100061107 & Garretts Run-Allegheny River & OHIO & 2 & & $\mathrm{X}$ & $\mathrm{X}$ \\
\hline 050100070101 & North Branch Quemahoning Creek & OHIO & 2 & & $\mathrm{X}$ & $\mathrm{X}$ \\
\hline 050100070102 & Beaverdam Creek-Quemahoning Creek & OHIO & 2 & & $\mathrm{X}$ & $\mathrm{X}$ \\
\hline 050100070103 & Roaring Run-Quemahoning Creek & OHIO & 2 & & $\mathrm{X}$ & $\mathrm{X}$ \\
\hline 050100070202 & Clear Shade Creek & OHIO & 2 & & $\mathrm{X}$ & $\mathrm{X}$ \\
\hline 050100070203 & Shade Creek-Stony Creek & $\mathrm{OHIO}$ & 2 & & $\mathrm{X}$ & $\mathrm{X}$ \\
\hline 050100070303 & Wells Creek & $\mathrm{OHIO}$ & 2 & & $\mathrm{X}$ & $\mathrm{X}$ \\
\hline 050100070304 & Beaverdam Creek & OHIO & 2 & & $\mathrm{X}$ & $\mathrm{X}$ \\
\hline 050100070306 & Middle Stonycreek River & OHIO & 2 & & $\mathrm{X}$ & $\mathrm{X}$ \\
\hline 050100070307 & Paint Creek & $\mathrm{OHIO}$ & 2 & & $\mathrm{X}$ & $\mathrm{X}$ \\
\hline 050100070310 & Lower Stonycreek River-Conemaugh River & OHIO & 2 & & $\mathrm{X}$ & $\mathrm{X}$ \\
\hline 050100070501 & North Branch Little Conemaugh & OHIO & 2 & & $\mathrm{X}$ & $\mathrm{X}$ \\
\hline 050100070502 & Bens Creek-Little Conemaugh River & OHIO & 2 & & $\mathrm{X}$ & $\mathrm{X}$ \\
\hline 050100070601 & Elk Creek & OHIO & 2 & & $\mathrm{X}$ & $\mathrm{X}$ \\
\hline 050100071001 & Hinckston Run-Conemaugh River & $\mathrm{OHIO}$ & 2 & & $\mathrm{X}$ & $\mathrm{X}$ \\
\hline 050100071002 & Baldwin Creek-Conemaugh River & OHIO & 2 & & $\mathrm{X}$ & $\mathrm{X}$ \\
\hline 050100071005 & Richards Run-Conemaugh River & OHIO & 2 & & $\mathrm{X}$ & $\mathrm{X}$ \\
\hline 050100071006 & McGee Run & OHIO & 2 & & $\mathrm{X}$ & $\mathrm{X}$ \\
\hline 050100071007 & Aultmans Run & OHIO & 2 & & $\mathrm{X}$ & $\mathrm{X}$ \\
\hline 050100071008 & Conemaugh River-Kiskiminetas River & OHIO & 2 & & $\mathrm{X}$ & $\mathrm{X}$ \\
\hline 050100080102 & Mill Creek & OHIO & 2 & & $\mathrm{X}$ & $\mathrm{X}$ \\
\hline 050100080103 & Fourmile Run & OHIO & 2 & & $\mathrm{X}$ & $\mathrm{X}$ \\
\hline 050100080104 & Upper Loyalhanna Creek & $\mathrm{OHIO}$ & 2 & & $\mathrm{X}$ & $\mathrm{X}$ \\
\hline 050100080105 & Ninemile Run & OHIO & 2 & & $\mathrm{X}$ & $\mathrm{X}$ \\
\hline 050100080106 & Middle Loyalhanna Creek & OHIO & 2 & & $\mathrm{X}$ & $\mathrm{X}$ \\
\hline 050100080107 & Crabtree Creek & OHIO & 2 & & $\mathrm{X}$ & $\mathrm{X}$ \\
\hline 050100080108 & Lower Loyalhanna Creek & OHIO & 2 & & $\mathrm{X}$ & $\mathrm{X}$ \\
\hline 050100080202 & Roaring Run-Kiskiminetas River & OHIO & 2 & & $\mathrm{X}$ & $\mathrm{X}$ \\
\hline 050100080204 & Pine Run & OHIO & 2 & & $\mathrm{X}$ & $\mathrm{X}$ \\
\hline 050100080205 & Kiskiminetas River-Allegheny River & OHIO & 2 & & $\mathrm{X}$ & $\mathrm{X}$ \\
\hline 050100090201 & Pine Creek-North Park Lake & OHIO & 2 & & $\mathrm{X}$ & $\mathrm{X}$ \\
\hline 050100090301 & Bull Creek & OHIO & 2 & & $\mathrm{X}$ & $\mathrm{X}$ \\
\hline 050100090302 & Pucketa Creek & OHIO & 2 & & $\mathrm{X}$ & $\mathrm{X}$ \\
\hline 050100090303 & Deer Creek & OHIO & 2 & & $\mathrm{X}$ & $\mathrm{X}$ \\
\hline 050100090304 & Chartiers Run-Allegheny River & OHIO & 2 & & $\mathrm{X}$ & $\mathrm{X}$ \\
\hline
\end{tabular}


Appendix 5. Complete listing of HUC12 watersheds in Pennsylvania and the Susquehanna River Basin in Pennsylvania and New York with basin characteristic, geographic, or streamflow correlation gaps.-Continued

[HUC12, 12-digit hydrologic unit code; DEL, Delaware River Basin; STLAW, Saint Lawrence River Basin; OHIO, Ohio River Basin; POT, Potomac River Basin; SUSQ, Susquehanna River Basin; SUSQ NY, Susquehanna River Basin watersheds entirely in New York; X, indicates gap]

\begin{tabular}{|c|c|c|c|c|c|c|}
\hline $\begin{array}{c}\text { HUC12 } \\
\text { identification number }\end{array}$ & HUC12 name & Basin & $\begin{array}{c}\text { Num- } \\
\text { ber of } \\
\text { gaps }\end{array}$ & $\begin{array}{c}\text { Basin } \\
\text { charac- } \\
\text { teristic } \\
\text { gap }\end{array}$ & $\begin{array}{l}\text { Geo- } \\
\text { graph- } \\
\text { ic gap }\end{array}$ & $\begin{array}{l}\text { Stream- } \\
\text { flow cor- } \\
\text { relation } \\
\text { gap }\end{array}$ \\
\hline 050200040601 & Fike Run-Little Sandy Creek & OHIO & 2 & & $\mathrm{X}$ & $\mathrm{X}$ \\
\hline 050200040707 & Cheat Lake-Cheat River & OHIO & 2 & & $\mathrm{X}$ & $\mathrm{X}$ \\
\hline 050200050401 & Bane Creek & OHIO & 2 & & $\mathrm{X}$ & $\mathrm{X}$ \\
\hline 050200050402 & Short Creek-Tenmile Creek & OHIO & 2 & & $\mathrm{X}$ & $\mathrm{X}$ \\
\hline 050200050502 & Browns Run & OHIO & 2 & & $\mathrm{X}$ & $\mathrm{X}$ \\
\hline 050200050504 & Muddy Creek & OHIO & 2 & & $\mathrm{X}$ & $\mathrm{X}$ \\
\hline 050200050703 & Thompson Run & OHIO & 2 & $\mathrm{X}$ & & $\mathrm{X}$ \\
\hline 050200050704 & Sawmill Run-Turtle Creek & OHIO & 2 & $\mathrm{X}$ & & $\mathrm{X}$ \\
\hline 050200050801 & Pike Run & OHIO & 2 & & $\mathrm{X}$ & $\mathrm{X}$ \\
\hline 050200050802 & Little Redstone Creek-Monongahela River & OHIO & 2 & & $\mathrm{X}$ & $\mathrm{X}$ \\
\hline 050200050803 & Maple Creek-Monongahela River & OHIO & 2 & & $\mathrm{X}$ & $\mathrm{X}$ \\
\hline 050200050804 & Pigeon Creek & OHIO & 2 & & $\mathrm{X}$ & $\mathrm{X}$ \\
\hline 050200050805 & Mingo Creek-Monongahela River & OHIO & 2 & & $\mathrm{X}$ & $\mathrm{X}$ \\
\hline 050200060303 & Buffalo Run & OHIO & 2 & & $\mathrm{X}$ & $\mathrm{X}$ \\
\hline 050200060304 & Mill Run & $\mathrm{OHIO}$ & 2 & & $\mathrm{X}$ & $\mathrm{X}$ \\
\hline 050200060906 & Dickerson Run-Youghiogheny River & OHIO & 2 & & $\mathrm{X}$ & $\mathrm{X}$ \\
\hline 050200061001 & Headwaters Jacobs Creek & OHIO & 2 & & $\mathrm{X}$ & $\mathrm{X}$ \\
\hline 050200061002 & Jacobs Creek-Youghiogheny River & OHIO & 2 & & $\mathrm{X}$ & $\mathrm{X}$ \\
\hline 050200061101 & Jacks Run & $\mathrm{OHIO}$ & 2 & & $\mathrm{X}$ & $\mathrm{X}$ \\
\hline 050200061102 & Upper Sewickley Creek & OHIO & 2 & & $\mathrm{X}$ & $\mathrm{X}$ \\
\hline 050200061103 & Little Sewickley Creek & OHIO & 2 & & $\mathrm{X}$ & $\mathrm{X}$ \\
\hline 050200061104 & Lower Sewickley Creek & OHIO & 2 & & $\mathrm{X}$ & $\mathrm{X}$ \\
\hline 050200061201 & Cedar Creek-Youghiogheny River & OHIO & 2 & & $\mathrm{X}$ & $\mathrm{X}$ \\
\hline 050200061202 & Long Run & OHIO & 2 & & $\mathrm{X}$ & $\mathrm{X}$ \\
\hline 050301010102 & Upper Chartiers Creek & OHIO & 2 & & $\mathrm{X}$ & $\mathrm{X}$ \\
\hline 050301010104 & Middle Chartiers Creek & OHIO & 2 & $\mathrm{X}$ & & $\mathrm{X}$ \\
\hline 050301010107 & Lower Chartiers Creek & OHIO & 2 & $\mathrm{X}$ & & $\mathrm{X}$ \\
\hline 050301010203 & Headwaters Racoon Creek-Cherry Valley Reservoir & OHIO & 2 & & $\mathrm{X}$ & $\mathrm{X}$ \\
\hline
\end{tabular}


Appendix 5. Complete listing of HUC12 watersheds in Pennsylvania and the Susquehanna River Basin in Pennsylvania and New York with basin characteristic, geographic, or streamflow correlation gaps.-Continued

[HUC12, 12-digit hydrologic unit code; DEL, Delaware River Basin; STLAW, Saint Lawrence River Basin; OHIO, Ohio River Basin; POT, Potomac River Basin; SUSQ, Susquehanna River Basin; SUSQ NY, Susquehanna River Basin watersheds entirely in New York; X, indicates gap]

\begin{tabular}{|c|c|c|c|c|c|c|}
\hline $\begin{array}{c}\text { HUC12 } \\
\text { identification number }\end{array}$ & HUC12 name & Basin & $\begin{array}{l}\text { Num- } \\
\text { ber of } \\
\text { gaps }\end{array}$ & $\begin{array}{c}\text { Basin } \\
\text { charac- } \\
\text { teristic } \\
\text { gap }\end{array}$ & $\begin{array}{l}\text { Geo- } \\
\text { graph- } \\
\text { ic gap }\end{array}$ & $\begin{array}{l}\text { Stream- } \\
\text { flow cor- } \\
\text { relation } \\
\text { gap }\end{array}$ \\
\hline 050301010306 & Flaugherty Run & $\mathrm{OHIO}$ & 2 & $\mathrm{X}$ & $\mathrm{X}$ & \\
\hline 050301010603 & Headwaters North Fork Little Beaver Creek & OHIO & 2 & $\mathrm{X}$ & $\mathrm{X}$ & \\
\hline 050301010607 & Dilworth Run-North Fork Little Beaver Creek & OHIO & 2 & & $\mathrm{X}$ & $\mathrm{X}$ \\
\hline 050301011101 & Mill CreeK & OHIO & 2 & & $\mathrm{X}$ & $\mathrm{X}$ \\
\hline 050301011103 & Carpenter Run-Ohio River & OHIO & 2 & & $\mathrm{X}$ & $\mathrm{X}$ \\
\hline 050301011104 & Tomlinson Run & OHIO & 2 & & $\mathrm{X}$ & $\mathrm{X}$ \\
\hline 050301011105 & Kings Creek & OHIO & 2 & & $\mathrm{X}$ & $\mathrm{X}$ \\
\hline 050301011108 & Harmon Creek & $\mathrm{OHIO}$ & 2 & & $\mathrm{X}$ & $\mathrm{X}$ \\
\hline 050301020101 & Paden Creek & OHIO & 2 & & $\mathrm{X}$ & $\mathrm{X}$ \\
\hline 050301020103 & Bennett Run-Frontal Pymatuning Reservoir & OHIO & 2 & & $\mathrm{X}$ & $\mathrm{X}$ \\
\hline 050301020402 & Big Run & OHIO & 2 & & $\mathrm{X}$ & $\mathrm{X}$ \\
\hline 050301020404 & Shenango River Lake-Shenango River & $\mathrm{OHIO}$ & 2 & & $\mathrm{X}$ & $\mathrm{X}$ \\
\hline 050301020405 & Shenango River Lake Dam-Shenango River & $\mathrm{OHIO}$ & 2 & & $\mathrm{X}$ & $\mathrm{X}$ \\
\hline 050301020503 & Otter Creek & OHIO & 2 & & $\mathrm{X}$ & $\mathrm{X}$ \\
\hline 050301020504 & Pine Run-Neshannock Creek & OHIO & 2 & & $\mathrm{X}$ & $\mathrm{X}$ \\
\hline 050301020505 & West Branch Little Neshannock Creek & $\mathrm{OHIO}$ & 2 & & $\mathrm{X}$ & $\mathrm{X}$ \\
\hline 050301020506 & Little Neshannock Creek & OHIO & 2 & & $\mathrm{X}$ & $\mathrm{X}$ \\
\hline 050301020602 & Little Yankee Run & $\mathrm{OHIO}$ & 2 & & $\mathrm{X}$ & $\mathrm{X}$ \\
\hline 050301020604 & Hogback Run-Shenango River & OHIO & 2 & & $\mathrm{X}$ & $\mathrm{X}$ \\
\hline 050301020605 & Big Run & OHIO & 2 & & $\mathrm{X}$ & $\mathrm{X}$ \\
\hline 050301020606 & Deer Creek-Shenango River & $\mathrm{OHIO}$ & 2 & & $\mathrm{X}$ & $\mathrm{X}$ \\
\hline 050301030808 & Hickory Run & OHIO & 2 & & $\mathrm{X}$ & $\mathrm{X}$ \\
\hline 050301030809 & Coffee Run-Mahoning River & OHIO & 2 & & $\mathrm{X}$ & $\mathrm{X}$ \\
\hline 050301050301 & Seaton Creek-Slippery Rock Creek & OHIO & 2 & & $\mathrm{X}$ & $\mathrm{X}$ \\
\hline 050301050302 & North Branch Slippery Rock Creek & OHIO & 2 & & $\mathrm{X}$ & $\mathrm{X}$ \\
\hline 050301060103 & Dutch Fork & OHIO & 2 & & $\mathrm{X}$ & $\mathrm{X}$ \\
\hline 050301060104 & Castleman Run & OHIO & 2 & & $\mathrm{X}$ & $\mathrm{X}$ \\
\hline 050301060105 & Sugarcamp Run-Buffalo Creek & OHIO & 2 & & $\mathrm{X}$ & $\mathrm{X}$ \\
\hline 050301060401 & Templeton Fork & OHIO & 2 & & $\mathrm{X}$ & $\mathrm{X}$ \\
\hline 050301060402 & Robinson Fork & OHIO & 2 & & $\mathrm{X}$ & $\mathrm{X}$ \\
\hline 050301060403 & Enlow Fork & OHIO & 2 & & $\mathrm{X}$ & $\mathrm{X}$ \\
\hline 050301060501 & North Fork Dunkard Fork & OHIO & 2 & $\mathrm{X}$ & $\mathrm{X}$ & \\
\hline 050301060503 & Outlet Dunkard Fork & OHIO & 2 & & $\mathrm{X}$ & $\mathrm{X}$ \\
\hline 050301060601 & Upper Wheeling Creek & OHIO & 2 & & $\mathrm{X}$ & $\mathrm{X}$ \\
\hline 050301060602 & Middle Wheeling Creek & OHIO & 2 & & $\mathrm{X}$ & $\mathrm{X}$ \\
\hline 050301060603 & Little Wheeling Creek & OHIO & 2 & & $\mathrm{X}$ & $\mathrm{X}$ \\
\hline 020401010403 & Factory Creek-Delaware River & DEL & 3 & $\mathrm{X}$ & $\mathrm{X}$ & $\mathrm{X}$ \\
\hline 020401010406 & Pea Brook-Delaware River & DEL & 3 & $\mathrm{X}$ & $\mathrm{X}$ & $\mathrm{X}$ \\
\hline 020401040401 & Upper Shahola Creek & DEL & 3 & $\mathrm{X}$ & $\mathrm{X}$ & $\mathrm{X}$ \\
\hline 020401040402 & Middle Shahola Creek & DEL & 3 & $\mathrm{X}$ & $\mathrm{X}$ & $\mathrm{X}$ \\
\hline 020401040701 & Sawkill Creek & DEL & 3 & $\mathrm{X}$ & $\mathrm{X}$ & $\mathrm{X}$ \\
\hline
\end{tabular}


Appendix 5. Complete listing of HUC12 watersheds in Pennsylvania and the Susquehanna River Basin in Pennsylvania and New York with basin characteristic, geographic, or streamflow correlation gaps.-Continued

[HUC12, 12-digit hydrologic unit code; DEL, Delaware River Basin; STLAW, Saint Lawrence River Basin; OHIO, Ohio River Basin; POT, Potomac River Basin; SUSQ, Susquehanna River Basin; SUSQ NY, Susquehanna River Basin watersheds entirely in New York; X, indicates gap]

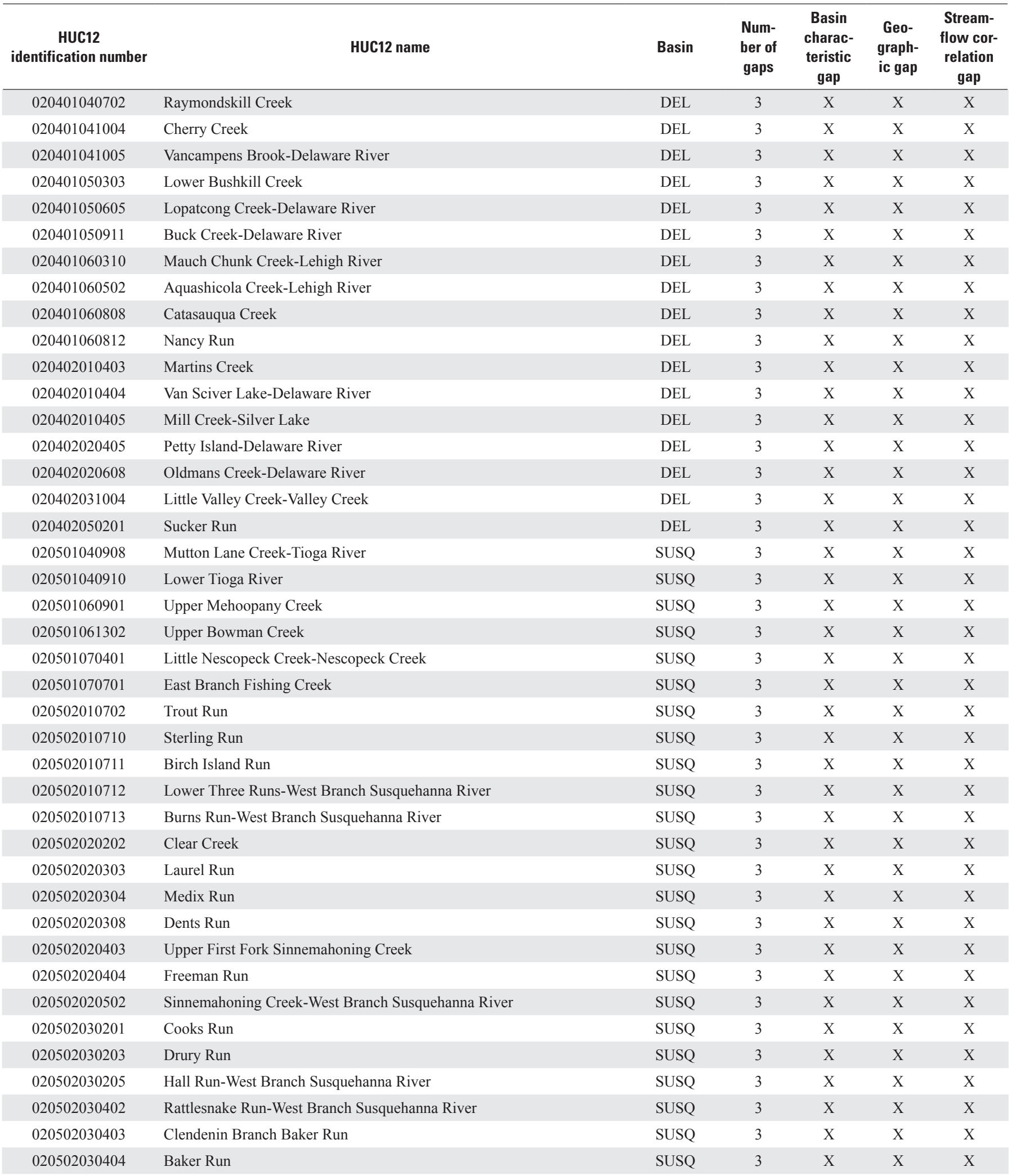


Appendix 5. Complete listing of HUC12 watersheds in Pennsylvania and the Susquehanna River Basin in Pennsylvania and New York with basin characteristic, geographic, or streamflow correlation gaps.-Continued

[HUC12, 12-digit hydrologic unit code; DEL, Delaware River Basin; STLAW, Saint Lawrence River Basin; OHIO, Ohio River Basin; POT, Potomac River Basin; SUSQ, Susquehanna River Basin; SUSQ NY, Susquehanna River Basin watersheds entirely in New York; X, indicates gap]

\begin{tabular}{|c|c|c|c|c|c|c|}
\hline $\begin{array}{c}\text { HUC12 } \\
\text { identification number }\end{array}$ & HUC12 name & Basin & $\begin{array}{c}\text { Num- } \\
\text { ber of } \\
\text { gaps }\end{array}$ & $\begin{array}{l}\text { Basin } \\
\text { charac- } \\
\text { teristic } \\
\text { gap }\end{array}$ & $\begin{array}{l}\text { Geo- } \\
\text { graph- } \\
\text { ic gap }\end{array}$ & $\begin{array}{l}\text { Stream- } \\
\text { flow cor- } \\
\text { relation } \\
\text { gap }\end{array}$ \\
\hline 020502030405 & North Fork Tangascootack Creek & SUSQ & 3 & $\mathrm{X}$ & $\mathrm{X}$ & $\mathrm{X}$ \\
\hline 020502030406 & Tangascootack Creek & SUSQ & 3 & $\mathrm{X}$ & $\mathrm{X}$ & $\mathrm{X}$ \\
\hline 020502030407 & Lick Run & SUSQ & 3 & $\mathrm{X}$ & $\mathrm{X}$ & $\mathrm{X}$ \\
\hline 020502030409 & Queens Run & SUSQ & 3 & $\mathrm{X}$ & $\mathrm{X}$ & $\mathrm{X}$ \\
\hline 020502030410 & McElhattan Creek & SUSQ & 3 & $\mathrm{X}$ & $\mathrm{X}$ & $\mathrm{X}$ \\
\hline 020502050201 & Ninemile Run & SUSQ & 3 & $\mathrm{X}$ & $\mathrm{X}$ & $\mathrm{X}$ \\
\hline 020502050505 & Otter Run & SUSQ & 3 & $\mathrm{X}$ & $\mathrm{X}$ & $\mathrm{X}$ \\
\hline 020502050604 & Mill Run-Pine Creek & SUSQ & 3 & $\mathrm{X}$ & $\mathrm{X}$ & $\mathrm{X}$ \\
\hline 020502050605 & Trout Run & SUSQ & 3 & $\mathrm{X}$ & $\mathrm{X}$ & $\mathrm{X}$ \\
\hline 020502050606 & Upper Pine Bottom Run-Pine Creek & SUSQ & 3 & $\mathrm{X}$ & $\mathrm{X}$ & $\mathrm{X}$ \\
\hline 020502061204 & Limestone Run-Northumberland County & SUSQ & 3 & $\mathrm{X}$ & $\mathrm{X}$ & $\mathrm{X}$ \\
\hline 020502061206 & Limestone Run-Union County & SUSQ & 3 & $\mathrm{X}$ & $\mathrm{X}$ & $\mathrm{X}$ \\
\hline 020503010902 & Rattling Creek & SUSQ & 3 & $\mathrm{X}$ & $\mathrm{X}$ & $\mathrm{X}$ \\
\hline 020503011002 & Fidlers Run-Susquehanna River & SUSQ & 3 & $\mathrm{X}$ & $\mathrm{X}$ & $\mathrm{X}$ \\
\hline 020503040102 & Mill Creek & SUSQ & 3 & $\mathrm{X}$ & $\mathrm{X}$ & $\mathrm{X}$ \\
\hline 020503040302 & Blacklog Creek & SUSQ & 3 & $\mathrm{X}$ & $\mathrm{X}$ & $\mathrm{X}$ \\
\hline 020503050201 & Rowe Run & SUSQ & 3 & $\mathrm{X}$ & $\mathrm{X}$ & $\mathrm{X}$ \\
\hline 020503050904 & Spring Creek & SUSQ & 3 & $\mathrm{X}$ & $\mathrm{X}$ & $\mathrm{X}$ \\
\hline 020503050906 & Swatara Creek-Susquehanna River & SUSQ & 3 & $\mathrm{X}$ & $\mathrm{X}$ & $\mathrm{X}$ \\
\hline 020503051002 & Clark Creek & SUSQ & 3 & $\mathrm{X}$ & $\mathrm{X}$ & $\mathrm{X}$ \\
\hline 020503051006 & Cove Creek-Susquehanna River & SUSQ & 3 & $\mathrm{X}$ & $\mathrm{X}$ & $\mathrm{X}$ \\
\hline 020503051008 & Spring Creek & SUSQ & 3 & $\mathrm{X}$ & $\mathrm{X}$ & $\mathrm{X}$ \\
\hline 020503051011 & Laurel Run-Susquehanna River & SUSQ & 3 & $\mathrm{X}$ & $\mathrm{X}$ & $\mathrm{X}$ \\
\hline 020503060102 & Plum Creek-South Branch Conewago Creek & SUSQ & 3 & $\mathrm{X}$ & $\mathrm{X}$ & $\mathrm{X}$ \\
\hline 020503060203 & Swift Run-Conewago Creek & SUSQ & 3 & $\mathrm{X}$ & $\mathrm{X}$ & $\mathrm{X}$ \\
\hline 020503060402 & Lower Little Conewago Creek & SUSQ & 3 & $\mathrm{X}$ & $\mathrm{X}$ & $\mathrm{X}$ \\
\hline 020503060502 & Davidsburg Run-Conewago Creek & SUSQ & 3 & $\mathrm{X}$ & $\mathrm{X}$ & $\mathrm{X}$ \\
\hline 020503060705 & Willis Run-Codorus Creek & SUSQ & 3 & $\mathrm{X}$ & $\mathrm{X}$ & $\mathrm{X}$ \\
\hline 020503060802 & Little Chickies Creek & SUSQ & 3 & $\mathrm{X}$ & $\mathrm{X}$ & $\mathrm{X}$ \\
\hline 020503060803 & Donegal Creek & SUSQ & 3 & $\mathrm{X}$ & $\mathrm{X}$ & $\mathrm{X}$ \\
\hline 020503060804 & Lower Chickies Creek & SUSQ & 3 & $\mathrm{X}$ & $\mathrm{X}$ & $\mathrm{X}$ \\
\hline 020503060904 & Cocalico Creek-Conestoga River & SUSQ & 3 & $\mathrm{X}$ & $\mathrm{X}$ & $\mathrm{X}$ \\
\hline 020503061104 & Middle Conestoga River & SUSQ & 3 & $\mathrm{X}$ & $\mathrm{X}$ & $\mathrm{X}$ \\
\hline 020503061502 & Tweed Creek-Octoraro Creek & SUSQ & 3 & $\mathrm{X}$ & $\mathrm{X}$ & $\mathrm{X}$ \\
\hline 020503061503 & Basin Run-Octoraro Creek & SUSQ & 3 & $\mathrm{X}$ & $\mathrm{X}$ & $\mathrm{X}$ \\
\hline 020503061701 & Conoy Creek & SUSQ & 3 & $\mathrm{X}$ & $\mathrm{X}$ & $\mathrm{X}$ \\
\hline 020503061702 & Hartman Run-Susquehanna River & SUSQ & 3 & $\mathrm{X}$ & $\mathrm{X}$ & $\mathrm{X}$ \\
\hline 020503061704 & Cabin Creek-Susquehanna River & SUSQ & 3 & $\mathrm{X}$ & $\mathrm{X}$ & $\mathrm{X}$ \\
\hline 020503061706 & Green Branch-Susquehanna River & SUSQ & 3 & $\mathrm{X}$ & $\mathrm{X}$ & $\mathrm{X}$ \\
\hline 020503061709 & Fishing Creek-Susquehanna River & SUSQ & 3 & $\mathrm{X}$ & $\mathrm{X}$ & $\mathrm{X}$ \\
\hline 020503061710 & Broad Creek & SUSQ & 3 & $\mathrm{X}$ & $\mathrm{X}$ & $\mathrm{X}$ \\
\hline
\end{tabular}


Appendix 5. Complete listing of HUC12 watersheds in Pennsylvania and the Susquehanna River Basin in Pennsylvania and New York with basin characteristic, geographic, or streamflow correlation gaps.-Continued

[HUC12, 12-digit hydrologic unit code; DEL, Delaware River Basin; STLAW, Saint Lawrence River Basin; OHIO, Ohio River Basin; POT, Potomac River Basin; SUSQ, Susquehanna River Basin; SUSQ NY, Susquehanna River Basin watersheds entirely in New York; X, indicates gap]

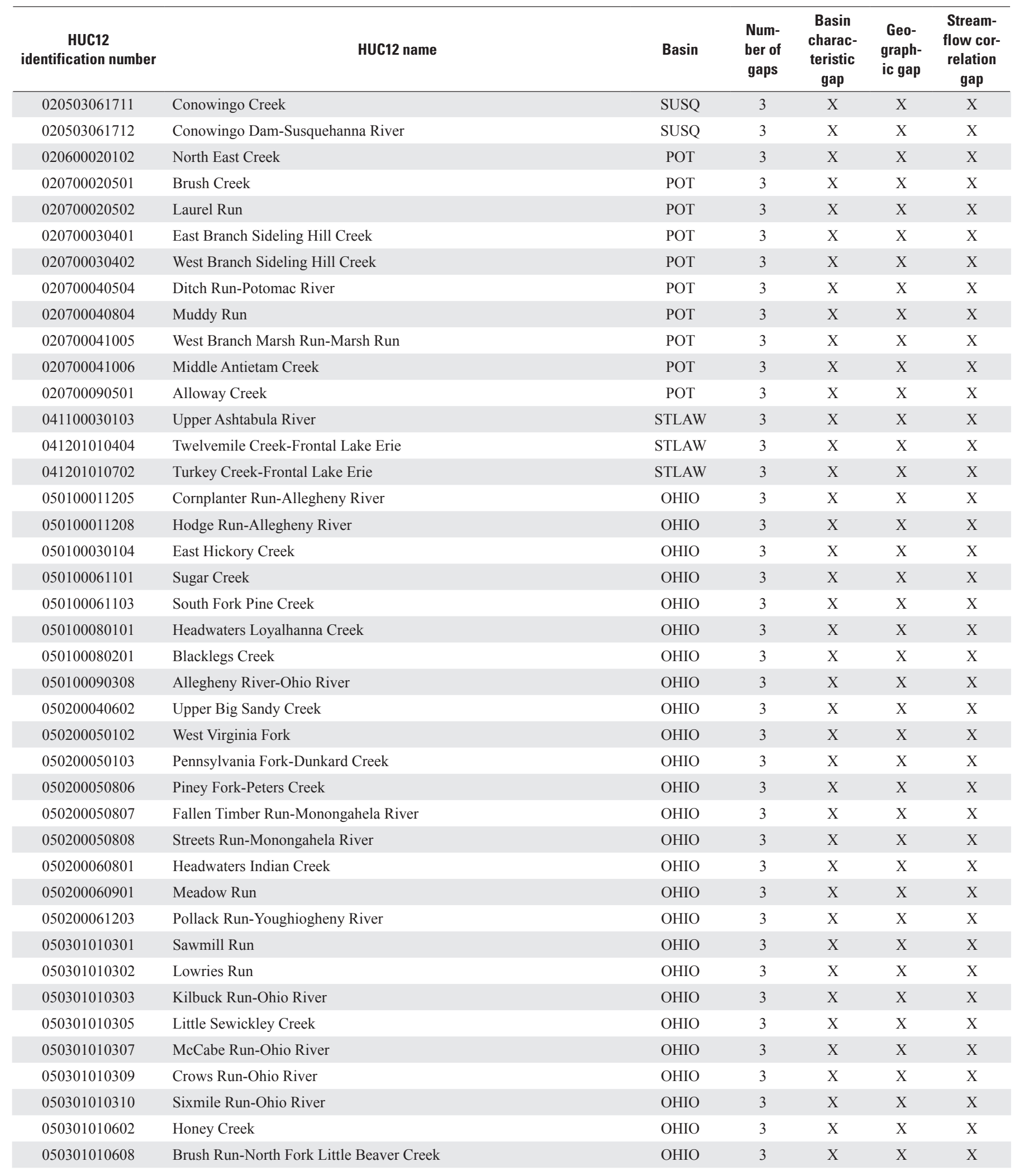


Appendix 5. Complete listing of HUC12 watersheds in Pennsylvania and the Susquehanna River Basin in Pennsylvania and New York with basin characteristic, geographic, or streamflow correlation gaps.-Continued

[HUC12, 12-digit hydrologic unit code; DEL, Delaware River Basin; STLAW, Saint Lawrence River Basin; OHIO, Ohio River Basin; POT, Potomac River Basin; SUSQ, Susquehanna River Basin; SUSQ NY, Susquehanna River Basin watersheds entirely in New York; X, indicates gap]

\begin{tabular}{|c|c|c|c|c|c|c|}
\hline $\begin{array}{c}\text { HUC12 } \\
\text { identification number }\end{array}$ & HUC12 name & Basin & $\begin{array}{c}\text { Num- } \\
\text { ber of } \\
\text { gaps }\end{array}$ & $\begin{array}{c}\text { Basin } \\
\text { charac- } \\
\text { teristic } \\
\text { gap }\end{array}$ & $\begin{array}{l}\text { Geo- } \\
\text { graph- } \\
\text { ic gap }\end{array}$ & $\begin{array}{l}\text { Stream- } \\
\text { flow cor- } \\
\text { relation } \\
\text { gap }\end{array}$ \\
\hline 050301020104 & Frontal Pymatuning Reservoir & $\mathrm{OHIO}$ & 3 & $\mathrm{X}$ & $\mathrm{X}$ & $\mathrm{X}$ \\
\hline 050301020105 & Pymatuning Reservoir & OHIO & 3 & $\mathrm{X}$ & $\mathrm{X}$ & $\mathrm{X}$ \\
\hline 050301040103 & Beaver River-Ohio River & OHIO & 3 & $\mathrm{X}$ & $\mathrm{X}$ & $\mathrm{X}$ \\
\hline 050301060502 & South Fork Dunkard Fork & $\mathrm{OHIO}$ & 3 & $\mathrm{X}$ & $\mathrm{X}$ & $\mathrm{X}$ \\
\hline 050301060802 & Grave Creek & OHIO & 3 & $\mathrm{X}$ & $\mathrm{X}$ & $\mathrm{X}$ \\
\hline 050301061001 & Upper West Virginia Fork Fish Creek & OHIO & 3 & $\mathrm{X}$ & $\mathrm{X}$ & $\mathrm{X}$ \\
\hline
\end{tabular}




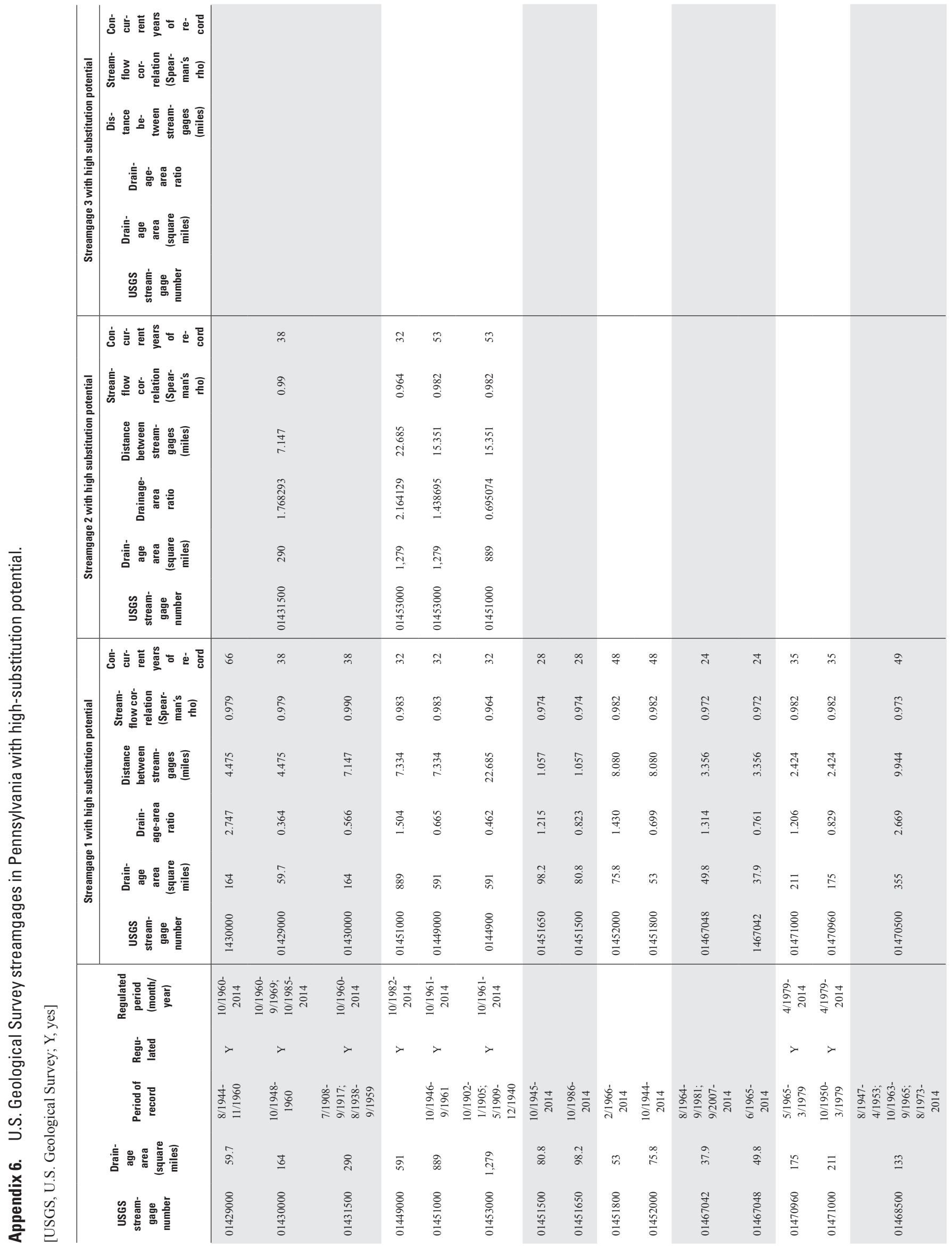




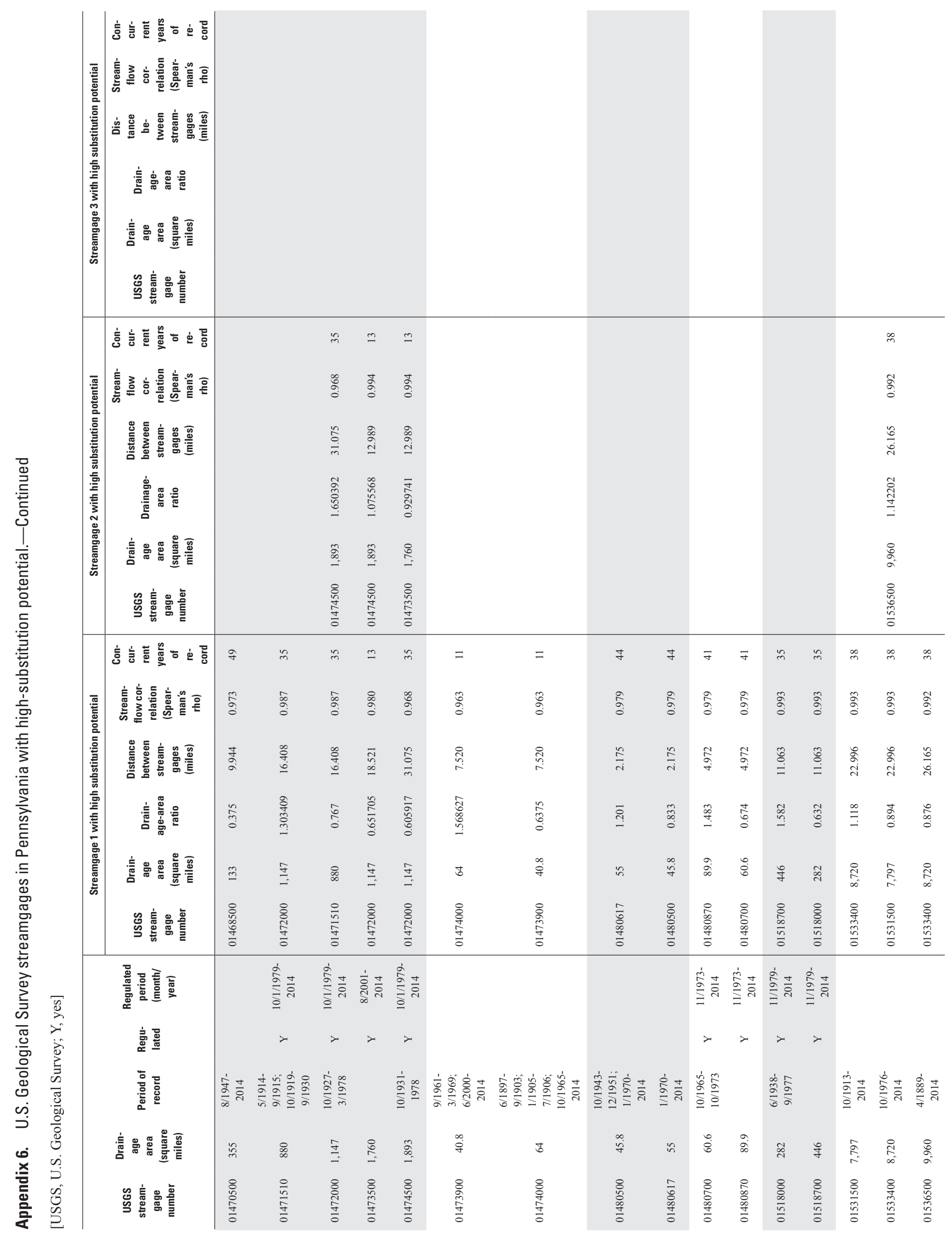




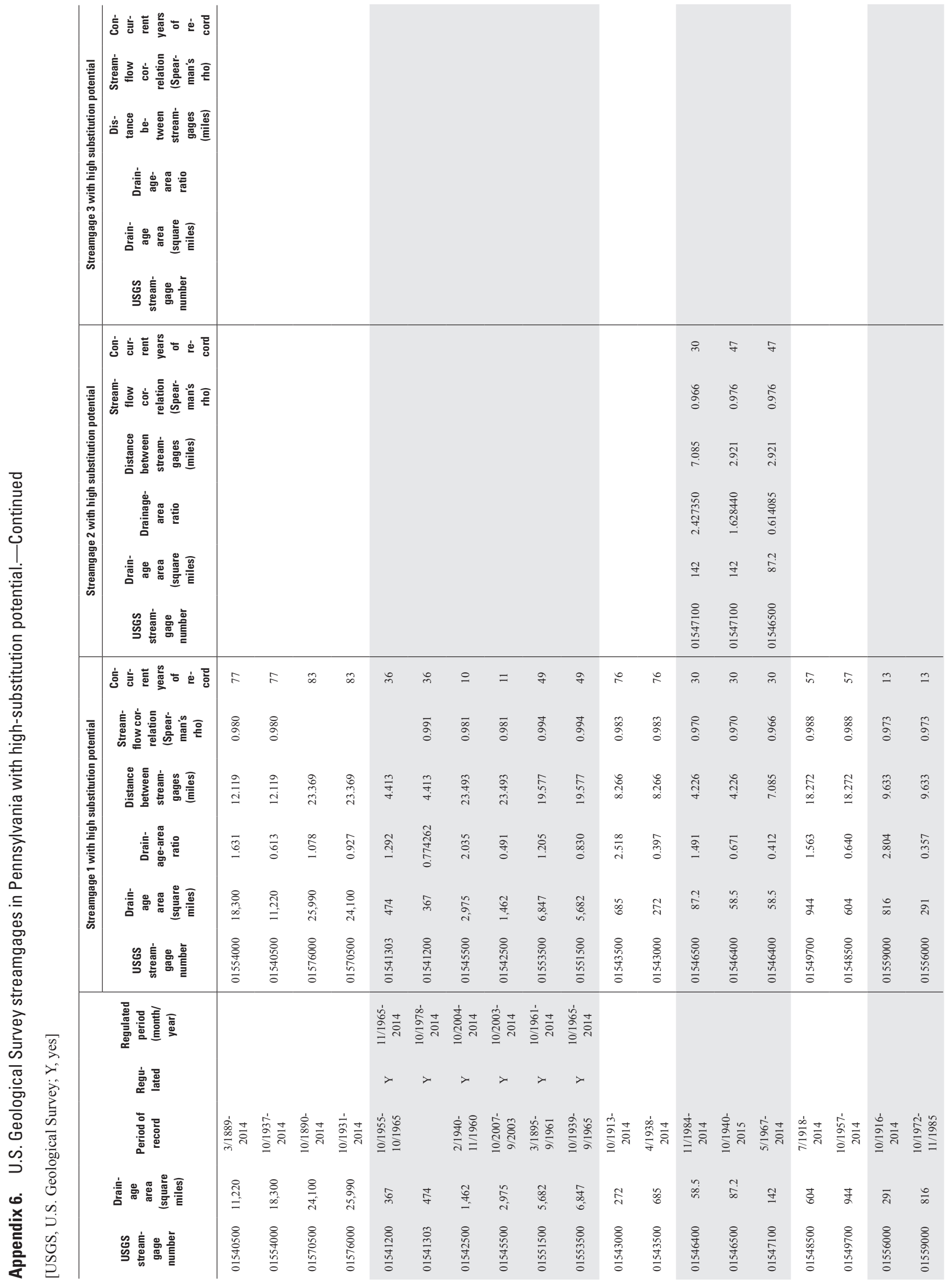




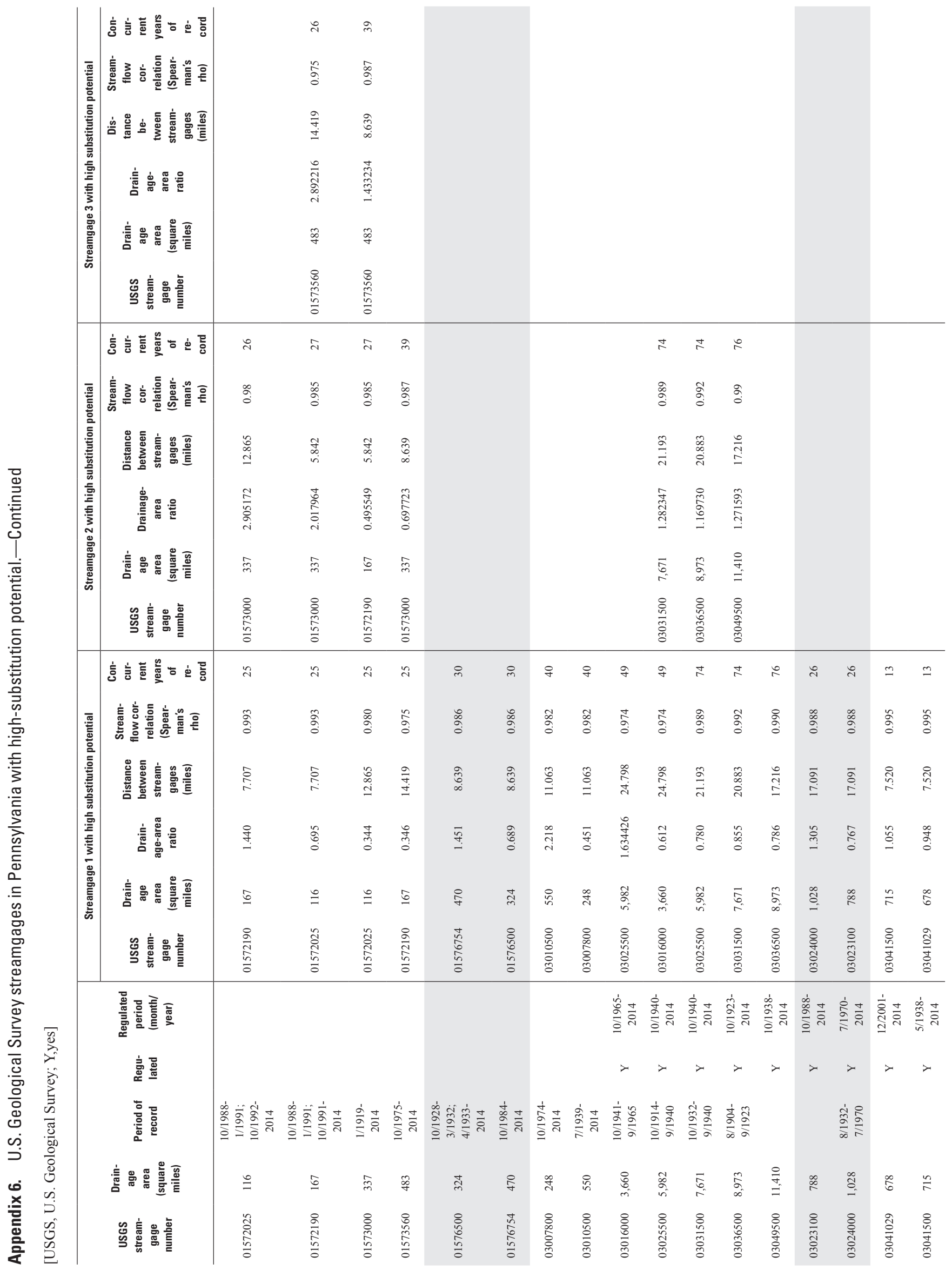




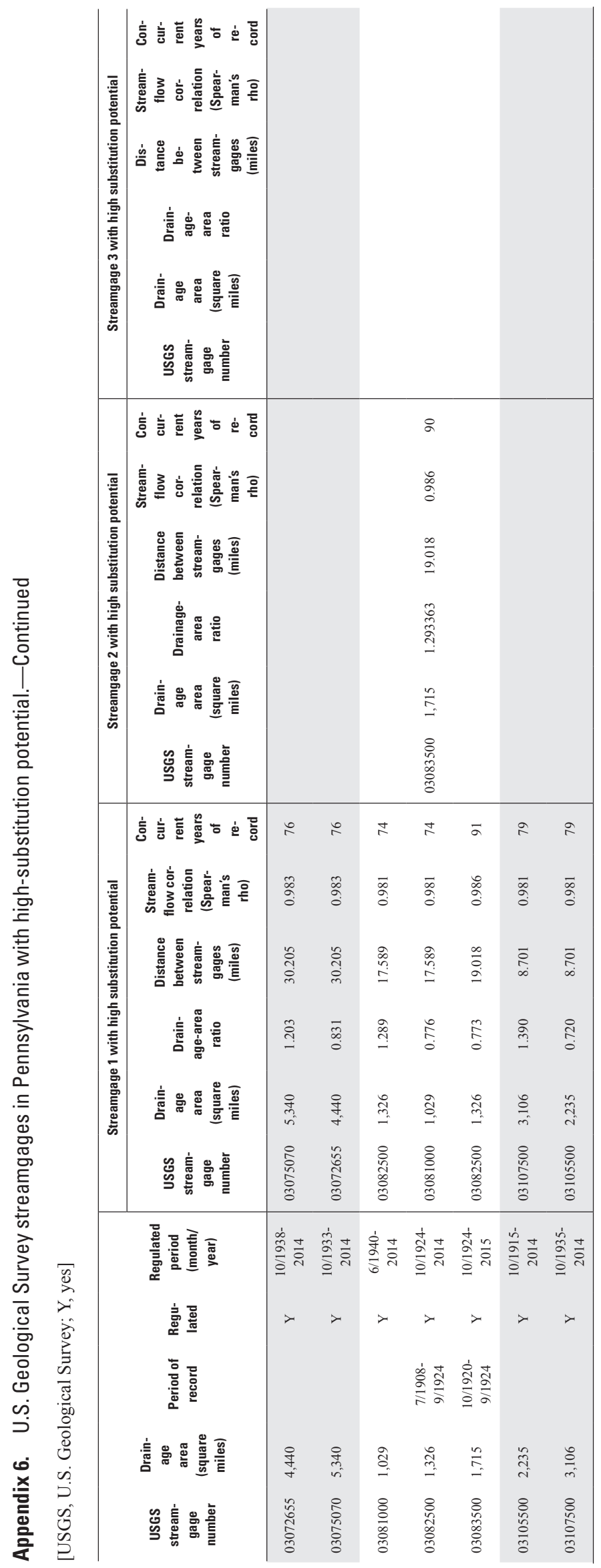


Prepared by USGS West Trenton Publishing Service Center.

For additional information, contact:

Director, Pennsylvania Water Science Center

U.S. Geological Survey

215 Limekiln Road

New Cumberland, PA 17070-2424

or visit our website at:

http://pa.water.usgs.gov 


\section{$\frac{2}{4}$}

